\title{
THIAGO RAGGI
}

Feeding and nutrition of tropical farmed fish and shrimp: pellet water stability, in vitro protein digestion, comparison of inert markers, evaluation of practical feeds, and dietary amino acid requirement

São Paulo

2016 


\section{THIAGO RAGGI}

Feeding and nutrition of tropical farmed fish and shrimp: pellet water stability, in vitro protein digestion, comparison of inert markers, evaluation of practical feeds, and dietary amino acid requirement

Thesis submitted to the Oceanographic Institute of the University of São Paulo, in fulfilment of the requirements for the degree of Doctor of Sciences

Oceanography Graduate Program, Biological Oceanography

Thesis advisor: Prof. Dr. Daniel Eduardo Lavanholi de Lemos Thesis co-advisor: Dr. Albert George Joseph Tacon 


\section{ACKNOWLEDGEMENTS}

I would like to express my deepest appreciation to:

All my family for their unconditional support throughout my education;

My advisors: Dr. Albert Tacon for his guidance, generous support and help, making me follow my passions, and Dr. Daniel Lemos for his guidance, patience and critical reviews - their generous contribution of time and knowledge helped make this endeavor possible;

All staff and friends at Instituto Oceaonográfico and Ubatuba research station;

Dr. Daniel Benetti and all the University of Miami Hatchery friends - appreciate everyone for all the support along the way;

João Manoel C. Alves for all your patience and support - always attending my endless solicitations;

CAPES and CNPq for granting me scholarships during the study period;

USP for granting me financial support to attend national and international conferences;

Lastly, I would like to thank my love, Karina, who were always there, every step of the way. 


\section{RESUMO}

RAGGI, T. Alimentação e nutrição de peixes e camarões tropicais cultivados: estabilidade do pélete na água, digestão proteica in vitro, comparação de marcadores inertes, avaliação de rações práticas, e exigência de aminoácidos na dieta. 2016. 280 f. Tese (Doutorado) - Instituto Oceanográfico, Universidade de São Paulo, São Paulo, 2016.

O objetivo dessa tese foi avaliar a alimentação e nutrição de peixes e camarões tropicais cultivados, visando a sua aplicação à aquicultura. Inicialmente, um estudo do atual panorama da qualidade das rações para tilapia e camarão cultivados no Brasil mostrou que a maioria das composições proximais das rações analisadas foram consistentes com os valores declarados pelos fabricantes, porém, a estabilidade das rações na água mostrou-se o oposto; o método in vitro $\mathrm{pH}$-stat com enzimas espécie-específica, para determinação do grau de hidrólise da proteína (DH), pode ser uma ferramenta útil para avaliar a qualidade das rações; a técnica da espectrofotometria do infravermelho próximo (NIRS) pode ser usada em várias aplicações na indústria de alimentos aquáticos, sendo uma ferramenta eficiente para avaliar rapidamente a qualidade dos alimentos em termos de DH. Um segundo estudo avaliou a cinza insolúvel em ácido (AIA) e óxido de cromo $\left(\mathrm{Cr}_{2} \mathrm{O}_{3}\right)$ como marcadores inertes, além de métodos de processamento de alimentos (extrusado industrial vs. peletizada a frio em laboratório) para determinar o coeficiente de digestibilidade aparente (ADC) da matéria seca e proteína bruta de juvenis de L. vannamei. O AIA mostrou ser um marcador endógeno natural eficaz para ensaios de digestibilidade com L. vanammei, no entanto, atenção especial deve ser dada aos níveis de AIA nas rações comerciais; a ração extrusada teve a melhor performance dos animais, porém, os valores de ADC entre as rações não foram significantemente diferentes. Além disso, dois experimentos de alimentação foram conduzidos com juvenis de beijupirá Rachycentron canadum: (1) experimento realizado em tanques-rede flutuantes para testar a eficácia nutricional de diferentes regimes alimentares, variando entre rejeito de pesca, rações preparadas em laboratório, e ração comercial extrusada; e (2) um experimento realizados em tanques com recirculação de água para testar a eficiência nutricional de diferentes potenciais substitutos de farinha de peixe, com dietas completas preparadas em laboratório. Em geral, o desempenho dos peixes foi superior no experimento realizado nos tanques-rede, comparado com o experimento nos tanques de recirculação de água; no geral o crescimento e performance dos peixes alimentados com as dietas experimentais foram bem similares, concluindo que ingredientes alternativos podem ser incluídos e substituírem parte (50\%) da farinha de peixe das rações; os resultados de ambos os estudos concluíram que o beijupirá $R$. canadum requer dietas práticas com alto teores de proteína bruta e lipídeos, e a inclusão de fontes proteicas de origem vegetal e animal foi possível. Os valores quantitativos das exigências de amino ácidos essenciais (EAA), estimados pelo método de acreção de proteína na carcaça, foram altamente correlacionados com as médias de exigência de cada EAA das as espécies de peixes carnívoros encontrados na literatura, e podem ser recomendados para a formulação de ração comercial para beijupirá $R$. canadum. Por último, uma tentativa de quantificar as exigências de amino ácidos sulforosos totais para Florida Pompano Trachinotus carolinus, foi realizada utilizando combinações de vários ingredientes proteicos a base de soja, a fim de desenvolver dietas de baixo custo e ecologicamente sustentáveis. Embora houve uma tendência clara nos resultados, os intervalos dos níveis de metionina utilizados nesse estudo podem não ter sido amplos o suficiente para medir com precisão a concentração alimentar necessária para estimar a exigência dos de amino ácidos sulforosos totais; além disso, a alta variação entre as replicas não forneceu uma estimativa robusta; este estudo de 45 dias não deve ter sido suficiente para mostrar diferenças significativas entre os tratamentos. 


\begin{abstract}
RAGGI, T. Feeding and nutrition of tropical farmed fish and shrimp: pellet water stability, in vitro protein digestion, comparison of inert markers, evaluation of practical feeds, and dietary amino acid requirement. 2016. 280 f. Tese (Doutorado) - Instituto Oceanográfico, Universidade de São Paulo, São Paulo, 2016.
\end{abstract}

The aim of this thesis was to evaluate the feeding and nutrition of tropical farmed fish and shrimp, targeting its applicability to aquaculture farming. The study of the actual panorama of aquafeed quality for tilapia Oreochromis niloticus and shrimp Litopenaeus vannamei farmed in Brazil showed that the proximate compositions between the analyzed feeds were mostly consistent with the declared values from the manufacturers, however, the feed water stability showed the opposite; the in vitro $\mathrm{pH}$-stat species-specific method to determine the protein degree of hydrolysis (DH) showed to be a useful tool to evaluate feed quality; and NIRS technique can be used in many applications throughout the aquafeed industry, being an efficient tool for rapidly assessing feed quality in terms of DH. A second study evaluated the acid-insoluble ash (AIA) and chromic oxide $\left(\mathrm{Cr}_{2} \mathrm{O}_{3}\right)$ as inert markers and feed processing method (industrial extruded vs. laboratory cold pelleted) to determine apparent digestibility coefficient (ADC) of dry matter and crude protein of juvenile L. vannamei. The AIA showed to be an effective natural endogenous marker for digestibility trials with $L$. vanammei, however, for commercial feeds attention should be paid to feed AIA level; the extruded feed showed better animal performance than the cold pelleted feed, however, ADC of both feeds were not significantly different from each other. Further, two feeding trials were conducted with juvenile cobia Rachycentron canadum: (1) feeding trial conducted within floating net cages to test the nutritional efficacy of different dietary feeding regimes ranging from the use of trashfish, in-house formulated feeds, to dry commercial extruded marine fish feed; and (2) feeding trial conducted within indoor water-recirculated tanks to test the nutritional efficiency of different potential dietary fishmeal replacers within dry in-house prepared diets. Generally, fish performance was superior in the net-cage feeding trial compared with the indoor water-recirculated tank trial; overall, the fish growth and performance of the experimental diets were very similar, showing that the alternative ingredients could be included and replace part $(50 \%)$ of the fishmeal component; the results from both trials concluded that the cobia requires practices diets with high levels of crude protein and lipid, and the inclusion of alternative plantbased and terrestrial animal protein sources was possible; the quantitative essential amino acid (EAA) requirement values estimated by the protein accretion method was highly correlated to the average of each of the EAA requirement for the species of carnivorous fish reported in the literature, and could be recommended for formulation of commercial feed for cobia $R$. canadum. Finally, a tentative to quantify the total sulfur amino acid requirement of juvenile Florida Pompano Trachinotus carolinus, was performed using combinations of various soybean protein products in order to develop cost-effective and environmentally-friendly diets. Although there was an apparent tendency in the results, the range of methionine levels employed in this study may not have been broad enough to accurately measure the dietary concentration necessary to estimate the total sulfur amino acid requirement; in addition, high variation results among the three replicates per diet did not provide sufficiency robustness for its estimation; this study within 45 days should not have been enough to show significant differences among the treatments. Long term feeding trials would be recommended from fingerling/juvenile to market size with full nutritional and economic evaluation of results. 


\section{CONTENTS}

GENERAL INTRODUCTION 23

$\begin{array}{ll}\text { References } & 26\end{array}$

CHAPTER 1 - Assessing the quality of commercial aquafeeds for Nile tilapia Oreochromis niloticus and Pacific white shrimp Litopenaeus vannamei farmed in Brazil: proximate composition, water stability, in vitro protein digestion, and use of near$\begin{array}{ll}\text { infrared spectroscopy (NIRS). } & 27\end{array}$

$\begin{array}{ll}\text { Preface } & 28\end{array}$

$\begin{array}{lr}\text { Abstract } & 29\end{array}$

$\begin{array}{ll}\text { 1.1 Introduction } & 30\end{array}$

Tilapia and shrimp farming in Brazil $\quad 30$

Pellet water stability $\quad 35$

In vitro degree of protein hydrolysis (DH) 37

Near-infrared reflectance spectroscopy (NIRS) 38

1.2 Materials and Methods 41

Farming areas 41

On farm feed samples collection $\quad 42$

Proximate feed analysis $\quad 46$

Water stability tests 46

In vitro degree of protein hydrolysis $(\mathrm{DH}) \quad 50$

NIRS survey 53

Preliminary prediction of DH test using NIRS 53

1.3 Results 55

Declared proximate composition $\quad 55$

Proximate composition and in vitro DH of commercial feeds 56

Differences between declared and analyzed CP and EE content 59

$\begin{array}{ll}\text { Pellet water stability } & 60\end{array}$

Pellet size and weight 65

NIRS utilization by the aquafeed industry in Brazil 66 
Preliminary prediction of DH test using NIRS 68

$\begin{array}{ll}\text { 1.4 Discussion } & 72\end{array}$

Proximate composition of commercial feed 72

In vitro degree of protein hydrolysis 75

$\begin{array}{ll}\text { Pellet water stability } & 76\end{array}$

NIRS utilization by the aquafeed industry in Brazil 78

$\begin{array}{ll}\text { Preliminary test with SBM samples } & 79\end{array}$

$\begin{array}{ll}1.5 \text { Conclusions } & 81\end{array}$

$\begin{array}{ll}\text { 1.6 References } & 83\end{array}$

CHAPTER 2 - Comparison of inert markers and feed processing method on the estimation of apparent nutrient digestibility in Pacific white shrimp Litopenaeus vannamei. 91

Abstract 92

2.1 Introduction 93

Global shrimp farming 93

Shrimp digestion $\quad 94$

Nutrient digestibility 94

Inert markers 95

Objectives of this study $\quad 97$

$\begin{array}{ll}\text { 2.2 Materials and Methods } & 98\end{array}$

Laboratory infrastructure 98

Feed preparation laboratory 105

$\begin{array}{ll}\text { Shrimp nursery } & 108\end{array}$

$\begin{array}{ll}\text { Experimental and commercial diets } & 110\end{array}$

Experimental design and feeding management 115

$\begin{array}{ll}\text { Feces collection } & 116\end{array}$

$\begin{array}{ll}\text { Termination of trial and performance analysis } & 118\end{array}$

$\begin{array}{lr}\text { Chemical analysis } & 120\end{array}$

$\begin{array}{ll}\text { Ingredients } & 120\end{array}$

$\begin{array}{lr}\text { Diets and feces } & 120\end{array}$

$\begin{array}{ll}\text { Apparent digestibility coefficients } & 122\end{array}$ 
Water quality

Statistical analysis

2.3 Results

Water quality

Feed offer

Animal performance

Marker analysis

Apparent digestibility coefficients

2.4 Discussion

CHAPTER 3 - Feeding of juvenile cobia Rachycentron canadum: Evaluation of practical feeds in floating net cages and comparison of different dietary fishmeal replacers within indoor tanks.

Preface

Abstract

3.1 Introduction

Species overview

Feeding habits

Cobia nutrient requirements

Amino acid requirement

Fishmeal replacement

Objectives

3.2 Materials and Methods

Field visits

Experimental animals and rearing

Experimental culture conditions

Sea net-cage feeding trial

Recirculated-tank based feeding trial

Diets and feeding protocols 
Ingredients

Sea net-cage feeding trial diets

Recirculating-water tanks feeding trial diets

Sea net-cage feeding trial protocol

Recirculating-water tank feeding trial protocol

Fish performance calculations

Feces collection

Liver histopathology and visual body cavity examination

Chemical analysis

Whole-body amino acids

Estimation of essential amino acid requirements

Water quality parameters

Statistical analysis

3.3 Results

Sea net-cage feeding trial

Water quality

Animal performance

Apparent digestibility coefficient

Feed intake

Hepatosomatic index

Histological examinations

Visual body cavity analysis

Diets, whole-body and trash-fish amino acid composition

Estimation of essential amino acid requirements

Recirculating-water tank feeding trial

Water quality

Growth and feed performance

Apparent digestibility coefficient

Feed intake

Hepatosomatic index 
$\begin{array}{ll}\text { 3.4 Discussion } & 207\end{array}$

$\begin{array}{ll}3.5 \text { Conclusions } & 225\end{array}$

$\begin{array}{ll}3.6 \text { References } & 226\end{array}$

CHAPTER 4 - Dietary methionine requirement of juvenile Florida pompano Trachinotus $\begin{array}{ll}\text { carolinus. } & 240\end{array}$

$\begin{array}{ll}\text { Preface } & 241\end{array}$

$\begin{array}{ll}\text { Abstract } & 242\end{array}$

4.1 Introduction 243

4.2 Materials and Methods 246

Experimental animals $\quad 246$

Experimental culture conditions $\quad 246$

$\begin{array}{ll}\text { Ingredients } & 248\end{array}$

$\begin{array}{ll}\text { Experimental diets } & 248\end{array}$

Manufacturing of experimental diets $\quad 254$

Feeding protocol 254

Fish performance calculations 256

$\begin{array}{ll}\text { Chemical analysis } & 258\end{array}$

$\begin{array}{ll}\text { Water quality parameters } & 258\end{array}$

$\begin{array}{ll}\text { Statistical analysis } & 258\end{array}$

$\begin{array}{ll}4.3 \text { Results } & 259\end{array}$

$\begin{array}{ll}\text { Water quality } & 259\end{array}$

Diets analysis 259

Animal performance $\quad 259$

$\begin{array}{ll}\text { Feed intake } & 261\end{array}$

Visceral somatic and hepatosomatic index 263

Broken-line regression 263

4.4 Discussion 265

$\begin{array}{lr}\text { 4.5 Conclusions } & 269\end{array}$

$\begin{array}{ll}4.6 \text { References } & 270\end{array}$ 
$\begin{array}{ll}\text { APPENDIX } & 278\end{array}$

$\begin{array}{ll}\text { Shrimp Annotated Bibliography } & 278\end{array}$ 


\section{LIST OF FIGURES}

\section{CHAPTER 1}

Figure 01 - Estimates of fish, shrimp and other aquatic organisms farmed in Brazil in 2014 (MPA/IBGE, 2015). *Tambaqui Colossoma macropomum, pacu Piaractus mesopotamicus, tambacu C. macropomum $x$ P. mesopotamicus, pirapitinga Piaractus brachypomus, and patinga P. mesopotamicus $x$ P. Brachypomus.

Figure 02 - Production of shrimp and fish feeds in Brazil on the last fifteen years (SINDIRAÇÕES, 2015).

Figure 03 - $\quad$ Tilapia and shrimp farming surveyed states: São Paulo (SP) and Rio Grande do Norte (RN).

Figure 04 - Animal are fed exclusively with extruded floating feeds (A). Overview of the tilapia farms located in the cities of Buritãma and Santa Fé do Sul, SP (B). Intensive cage system is distributed in the reservoirs $(\mathbf{C})$. Floating cages equipped with feeding ring (D).

Figure 05 - Shrimp farms located in the Rio Grande do Norte, RN. Commercial size is between 10 to $15 \mathrm{~g}(\mathbf{A})$. Shrimp are fed two to four times daily using pelleted feed distributed from fixed trays (B) by workers in kayaks (C). The largest shrimp farm in Brazil (D).

Figure 06 - Shrimp (A) and tilapia (B) feed labels examples, sampled from the visited farms.

Figure 07 - Equipments used for the pellet water stability applying the horizontal shaking method: refrigerated shaking water bath (A), $250 \mathrm{~mL}$ flasks (B), filtration apparatus with filter $(\mathbf{C})$. Dry recovered and original feed samples in the oven at $105^{\circ} \mathrm{C}$ for $24 \mathrm{~h}(\mathbf{D})$.

Figure 08 - Ready-to-use enzymes (A). Simulation of shrimp and fish digestion in a $\mathrm{pH}$-stat assay: reacting vessel kept temperature stable in glass jacket (B); potentiometric titrator $(\mathbf{C})$.

Figure 09 - Flow diagram of digestive enzyme extract preparation for the determination of the in vitro degree of protein hydrolysis (DH) Nile tilapia, Oreochromis niloticus and shrimp Litopenaeus vannamei. After preparation, the hydrolytic capacity of crude enzyme extracts was standardized according to DH of specific protein substrates. Frozen stored enzyme extracts $\left(-20^{\circ} \mathrm{C}\right)$ showed to be stable for use after several months.

Figure 10 - NIRS analyser used in the preliminary test with 34 SBM samples. 
Figure 11 - DH (\%) of the nineteen commercial feeds (F01 - F19) for tilapia, Oreochromis niloticus. Each bar is the mean of four replicate test (error bar is the standard deviation). Further details in Materials and Methods.

Figure 12 - DH (\%) of the sixteen commercial feeds (S01 - S16) for shrimp, Litopenaeus vannamei. Each bar is the mean of four replicate test (error bar is the standard deviation). Further details in Materials and Methods.

Figure 13 - Dry matter loss (\%) of the nineteen commercial feeds (F01 - F19) for Nile tilapia, Oreochromis niloticus. Each bar is the mean of five replicate test (error bar is the standard deviation). Each feed was tested for 5 minutes at $19^{\circ} \mathrm{C}$ and $32^{\circ} \mathrm{C}$. Further details in Materials and Methods.

Figure 14 - Dry matter loss (\%) of the sixteen commercial feeds (S01 - S16) for shrimp, Litopenaeus vannamei. Each bar is the mean of five replicate test (error bar is the standard deviation). Each feed was tested for 60 minutes at $24^{\circ} \mathrm{C}, 5 \mathrm{ppt}, 30^{\circ} \mathrm{C}, 5 \mathrm{ppt}$, $24^{\circ} \mathrm{C}, 35 \mathrm{ppt}, 30^{\circ} \mathrm{C}, 35 \mathrm{ppt}$. Further details in Materials and Methods.

Figure 15 - Original spectra data of the 34 soybean meal samples, ranging from 1,0000 to 4,000 $\mathrm{nm}$. The wavelength selected for the calibration set was between 4,000 to 9,000 nm.

Figure 16 - The plot of NIR predicted DH against the determined values of soybean meal samples $(\mathrm{n}=102)$.

\section{CHAPTER 2}

Figure 01 - Global annual production (tonnes) of farm-raised shrimp (all species) and production value (US dollar) of L. vannamei over the last 30 years (FAO, 2016).

Figure 02 - Shrimp digestibility system adapted from the original system according CARVALHO et al., (2013) (A). View of the automatic belt-feeder loaded with feed (B).

Figure 03 - Overview of the closed recirculating system used for the digestibility trial with juvenile shrimp.

Figure 04 - View of the bottom of the tanks system used for the digestibility study with shrimp juveniles.

Figure 05 - Settling column used for feces sampling and solids removal.

Figure 06 - Polyethylene covers to reduce heat loss to the external environment, prevent the escape of animals and decrease lighting intensity inside the tanks. 
Figure 07 - The plumbing supply consisted of PVC pipes with different diameters for income and effluent water.

Figure 08 - Water filtration system: sand filter (blue) and the bead filter (green), which performs the mechanical and biological filtration, respectively.

Figure 09 - Industrial food mixer (A) used to blend the ingredients and cold-pellet the diets. Commercial mixture being cold pelleted (B); commercial mixture being cold pelleted with addition of the external marker chromic oxide $(\mathbf{C})$.

Figure 10 - Set of dies measuring between 1.0 to $10.0 \mathrm{~mm}$ of diameter used for pelleting diets.

Figure 11 - Drying cabinet built using an air blower at $38^{\circ} \mathrm{C}(\mathbf{A})$. View of the cabinet shelves accommodated alternately in order to let the air to flow and exit though the holes on top of the doors (B).

Figure 12 - Tanks of 1,000 L each used for the nursery phase, with shrimp fed commercial feed, using two automatic belt-feeders. Shrimp were cultured in the nursery tanks for 20 days and then transferred to a heterotrophic indoor system (biofloc).

Figure 13 - Moist pellets feed being prepared in the industrial mixer (A), which were then scattered and manually broken into smaller pieces $(\mathbf{B})$. The feed was placed over the dryer shelf, and then dried overnight until the moisture level was between 6.5$7.5 \%(\mathbf{C})$.

Figure 14 - Settling chambers were cleaned once a day with high pressure fresh water, in order to remove the feces, molt and left over feed from the previous night (A). Filtered shrimp feces with exuviae and uneaten feed (B).

Figure 15 - After harvested (A), shrimp were culled in ice and then enumerated, blotted dry and weighed in group by treatment tank (B).

Figure 16 - Feed quantity offered during the 7 weeks (48 days) of the trial. Each column represents the sum of seven replicates (tanks) from each treatment (feed). The week \#7 represents the sum of feed weight from six days.

Figure 17 - Potassium dichromate was used as a standard substance to obtain the standard curve ranging from 0.25 to $2.5 \mathrm{mg} / \mathrm{mL}$ of $\mathrm{Cr}_{2} \mathrm{O}_{3}$.

Figure 18 - Influence of feed sample quantity $(\mathrm{g})$ in the coefficient of variation (CV) of internal marker (acid insoluble ash - AIA) in two commercial shrimp feeds.

Figure 19 - Potential influence of the quantity of AIA (feed) in the ADC of dry matter (ADDM) and crude protein (ADCP).

Figure 20 - Influence of inert marker $\left(\mathrm{Cr}_{2} \mathrm{O}_{3}\right.$ and AIA) on the apparent digestibility coefficient 
(ADC) of dry matter. Each column represents the mean (s.d. as error bar) of seven tanks. Different superscript letters indicate significant difference $(P<0.05)$ within the same diet.

Figure 21 - Influence of inert marker $\left(\mathrm{Cr}_{2} \mathrm{O}_{3}\right.$ and AIA $)$ on the apparent digestibility coefficient (ADC) of crude protein. Each column represents the mean (s.d. as error bar) of seven tanks. Different superscript letters indicate significant difference $(P<0.05)$ within the same diet.

Figure 22 - Influence of feed processing on the apparent digestibility coefficient of dry matter and crude protein, using the marker AIA. Each column represents the mean (s.d. as error bar) of seven tanks.

\section{CHAPTER 3}

Figure 01 - Commercial grow-out farms: Small-scale (A) and industrial-scale (B) commercial cobia farm visited during the field trips, located in the city of Ubatuba and São Sebastião, respectively.

Figure 02 - Commercial grow-out farms: Floating cages were made by aluminum with wood (A) in the small-scale farm, and by high-density polyethylene (B) in the industrialscale farm. Fish were fed a commercial diet ( $45 \%$ crude protein and $15 \%$ lipids) twice daily (C). Fish were sold with 3-4 kg of live weight (D).

Figure 03 - Commercial hatchery: Broodstock tank in the commercial marine fish hatchery Redemar Alevinos (A), fingerlings of cobia Rachycentron canadum (B).

Figure 04 - Nursery: Fish were housed in a 7,000 L open flow system tank (A). Acclimation and maintenance of the fishes occurred over the course of 3 months, prior to grading and stocking $(\mathbf{B})$.

Figure 05 - Sea cage net: experimental floating cage net system for commercial marine fish located at the Oceanographic Institute, Ubatuba, Brazil.

Figure 06 - Sea cage net system: wooden frameworks developed to fit the cages and covers (A); lids made by a wooden structure, protecting the fishes against sunburns and natural predators $(\mathbf{B})$.

Figure 07 - Sea cage net management: the transportation was done by kayak and a small boat (A); the nets were hanged in a wooden framework that fit on the top of the platform (B); fouling was removed every two weeks (C); a PVC pipe frame was fitted into the bottom of each cages (D).

Figure 08 - Recirculated-tank feeding trial: the RAS was comprised of twenty-eight fiberglass tanks (A); eight juvenile cobias were placed into each of the experimental tanks 
(B); fish in each tank were weighed every two weeks to monitor growth performance $(\mathbf{C})$; animals were acclimated during one week, and fed with the maintenance $\operatorname{diet}(\mathbf{D})$.

Figure 09 - Feed preparation: ingredients were homogenized in an industrial food mixer (A); and cold-pelleted through a 3-mm die (B); trash-fish were bought from local fishing boats $(\mathbf{C})$; finished semi-moist feed prepared by mixing the Aquamar diet $(60 \%)$ with trash-fish (40\%) (D).

Figure 10 - Sea cage feeding trial protocols: diets were transported within insulated plastic containers (A); fish were hand-fed two times per day, at 09:00 and 16:00 $\mathrm{h}(\mathbf{B})$; the weighing process was done on the top of the floating platform $(\mathbf{C})$; animals were weighed in group (D).

Figure 11 - Recirculated tanks feeding trial protocols: fish were anesthetized using clove oil, and then weighed individually by treatment tank (A); feces were collected from each fish within each tank using stripping techniques (B); pictures from the body cavity of each fish were taken for visual analysis of organ coloration, and fat accumulation $(\mathbf{C})$.

Figure 12 - Feces collection: fish were anesthetized with clove oil before feces collection (A); feces were collected from each fish within each tank using stripping techniques (B).

Figure 13 - Temperature $\left({ }^{\circ} \mathrm{C}\right)$, salinity (ppt), and dissolved oxygen $(\mathrm{mg} / \mathrm{L})$ variations during the 70-day experimental period in the sea net-cage feeding trial.

Figure 14 - Total feed intake ( $\mathrm{kg}$, as is basis) of juvenile cobia Rachycentron canadum fed the three experimental diets and one commercial feed for 10 weeks (sum weigh; $\mathrm{n}=3$ ).

Figure 15 - Hepatosomatic index (HIS) of juvenile cobia Rachycentron canadum fed three experimental diet and one commercial feed for 10 weeks (mean $\pm \mathrm{sd} ; \mathrm{n}=3$ ). Different superscript letters indicate significant difference $(P<0.05)$.

Figure 16 - Hepatocytes from juvenile cobia Rachycentron canadum fed the four diets Aquamar (A), Semi-moist (B), Trash-fish (C), and Commercial (D), showing large lipid vacuoles (black arrows) occupying the whole cytoplasm and displacing cell nuclei to peripheral cell margins (hematoxylin-eosin, 40x). Bar $=20 \mu \mathrm{m}$.

Figure 17 - Visual body cavity: pictures of juvenile cobia Rachycentron canadum fed experimental diets (Aquamar (A), Trash-fish (B), Semi-moist (C)) and Commercial feed (D) for 10 weeks.

Figure 18 - Graphical comparison of methods for estimating essential amino acids (EAA) requirements from whole-body amino acid profile of cobia Rachycentron canadum. Arg: arginine, His: histidine, Iso: isoleucine, Leu: leucine, Lys: lysine, Met: methionine, Phe: phenylalanine, Thr: threonine, Try: tryptophan, Val: valine, and 
Tau: taurine. Ogino: Daily AA retention $(\%)=($ final $\%$ of specific AA * final body weight) - (initial \% of specific AA * initial body weight) / number of days; Arai (lys): EAA requirement $=(\mathrm{A} / \mathrm{E}$ of essential amino acid $*$ (lysine requirement $(\%))$ / (A/E ratio of lysine in the final WB). Lysine requirement of 2.33 (\% dry CP) estimated by broken-line (Zhou et al., 2007); Arai (met): EAA requirement $=(\mathrm{A} / \mathrm{E}$ of essential amino acid * (methionine requirement $(\%)) /(\mathrm{A} / \mathrm{E}$ ratio of methionine in the final WB). Methionine requirement of 1.19 (\% dry CP) estimated by brokenline (Zhou et al., 2006).

Figure 19 - Temperature $\left({ }^{\circ} \mathrm{C}\right)$, salinity $(\mathrm{ppt})$, and dissolved oxygen $(\mathrm{mg} / \mathrm{L})$ variations during the 70-day experimental period in the recirculating-water tank feeding trial.

Figure 20 - Total feed intake (kg, as fed basis) of juvenile cobia Rachycentron canadum fed the six experimental diets and one commercial feed for 10 weeks (sum weigh; $n=4$ ).

Figure 21 - Hepatosomatic index (HIS) of juvenile cobia Rachycentron canadum fed six experimental diet and one commercial feed for 10 weeks (mean $\pm \mathrm{sd}$; $\mathrm{n}=4$ ).

Figure 22 - Hepatocytes from juvenile cobia Rachycentron canadum fed the Commercial feed, showing large lipid vacuoles (A) occupying the whole cytoplasm and displacing cell nuclei (B) to peripheral cell margins (hematoxylin-eosin, 40x). Bar $=20 \mu \mathrm{m}$.

Figure 23 - Hepatocytes from juvenile cobia Rachycentron canadum fed the six experimental diets AM1-NFM (A), AM2-CFM (B), AM3-PBM (C), AM4-SPC (D), AM5-PBF (E), and AM6-TAU (F), showing large lipid vacuoles (black arrows) occupying the whole cytoplasm and displacing cell nuclei to peripheral cell margins (hematoxylin-eosin, 40x). Bar $=20 \mu \mathrm{m}$.

Figure 24 - Dark nodules in the liver (arrows) was found in fish fed the Commercial feed. Also, the increase of fat content, pale coloration and swollen liver was observed.

Figure 25 - Visual body cavity: pictures of juvenile cobia Rachycentron canadum fed the six experimental AM1-NFM (A), AM2-CFM (B), AM3-PBM (C), AM4-SPC (D), AM5-PBF (E), AM6-TAU (F) diets, and one commercial feed Commercial $(\mathbf{G})$ for 10 weeks.

Figure 26 - Average body weight (g/fish), daily feed intake (dry matter basis, $\mathrm{g} /$ fish), and water temperature $\left({ }^{\circ} \mathrm{C}\right)$ in the net-cage system, of cobia Rachycentron canadum fed trashfish for 70 days. 


\section{CHAPTER 4}

Figure 01 - Florida pompano Trachinotus carolinus juveniles stocked into a 12,000 L open flow system fiberglass tank $(\mathbf{A} ; \mathbf{B})$. Overview of the University of Miami Experimental Hatchery (C), comprised of eighteen polyethylene plastic tanks (D). Tanks were covered by a shading lid with natural illumination $(\mathbf{E})$. View from inside the tank of $1.0 \mathrm{~m}$ of diameter with a conical bottom $(\mathbf{F})$.

Figure 02 - Manufacturing of diets at the Fish Technology Center (Bozeman, MT, USA). Photo courtesy of Dr. Rick Barrows (A). Animals were anaesthetized (B), then individually weighed using a plastic ruler and an analytical balance (C). Twenty fish (average weight of $55.0 \pm 9.9 \mathrm{~g}$ ) were randomly distributed in each of the eighteen tank (D). The fish were fed test diets to apparent satiation (without overfeeding) twice daily at 9:00 and 16:00 h (E).

Figure 03 - At the termination of the experiment, all fish from each replicate of dietary treatments were pooled separately, culled, and individually weighted (A). Visceral somatic index and hepatosomatic index was calculated using three fish per treatment $(\mathbf{B})$.

Figure 04 - Relation between weight gain (\%) and dietary methionine (\%) among the six experimental diets with graded levels of L-methionine. Error bars represent \pm standard deviation.

Figure 05 - $\quad$ Total feed intake (kg, as is basis) of juvenile Florida pompano Trachinotus carolinus fed diets with graded levels of dietary methionine for 45 days (sum weigh; $\mathrm{n}=3$ ).

Figure 06 - Relation between dietary methionine level (x) and weight gain (y) of juvenile Florida pompano, as described by a straight-line broken-line regression model. 


\section{LIST OF TABLES}

\section{CHAPTER 1}

Table 01 - $\quad$ Pellet water stability method protocol for analysis of shrimp and fish feeds using the water bath apparatus.

Table 02 - Declared proximate composition of tilapia feeds collected in the farms (\%, "as is" basis).

Table 03 - Declared proximate composition of shrimp feeds collected in the farms (\%, "as is" basis).

Table 04 - Proximate composition (\%, "as is" basis) of commercial tilapia feeds.

Table 05 - $\quad$ Proximate composition (\%, "as is" basis) of commercial shrimp feeds.

Table 06 - Difference content (\%, "as is" basis) between the declared and analyzed crude protein $(\mathrm{CP})$ and ether extract $(\mathrm{EE})$ of the commercial tilapia feeds.

Table 07 - Difference content (\%, "as is" basis) between the declared and analyzed crude protein $(\mathrm{CP})$ and ether extract (EE) of the commercial shrimp feeds.

Table 08 - $\quad$ Tilapia feed processing, and dry matter loss (\%) at two different temperatures $\left(19^{\circ} \mathrm{C}\right.$ and $\left.32^{\circ} \mathrm{C}\right)$ and one salinity (0ppt) for 5 minutes.

Table 09 - Shrimp feed processing, and dry matter loss evaluated at two different temperatures $\left(24^{\circ} \mathrm{C}\right.$ and $\left.30^{\circ} \mathrm{C}\right)$ and salinities (5ppt and $\left.35 \mathrm{ppt}\right)$ for 60 minutes.

Table 10 - Sizes and weight analysis of pellets for the commercial tilapia Oreochromis niloticus feeds.

Table 11 - Sizes and weight analysis of pellets for the commercial shrimp Litopenaeus vannamei feeds.

Table 12 - Questionnaire about NIRS utilization: Aquafeeds.

Table 13 - Variability in soybean meal proximate composition (\%, as is) across all tested samples $(n=34)$.

Table 14 - NIR calibration to estimate DH of soybean meal samples. 


\section{CHAPTER 2}

Table 01 - Proximate and amino acid composition of the main ingredients used in the manufacture of the experimental diet "Aquamar Shrimp".

Table 02 - Formulation and proximate composition of the experimental diet "Aquamar Shrimp" fed to shrimp Litopenaeus vannamei during the 7 weeks indoor digestibility trial.

Table 03 - Proximate composition of the experimental and commercial diets fed to shrimp Litopenaeus vannamei during 7 weeks indoor digestibility trial.

Table 04 - Weight and temperature-dependent feeding rates used as reference in the trial.

Table 05 - Routine activities conducted over the 7-week digestibility trial.

Table 06 - Water quality over the 7-week feeding trial.

Table 07 - $\quad$ Performance of Litopeneus vannamei fed experimental and commercial diets for 7 weeks.

Table 08 - Influence of sample quantity (g) in the standard deviation (SD) and coefficient of variation $(\mathrm{CV})$ of internal marker (acid insoluble ash - AIA) in two commercial shrimp feeds.

Table 09 - $\quad$ Mean (s.d.) value and coefficient of variation (CV) of internal marker (acid insoluble ash - AIA) in feed and feces (\%, dry matter).

Table 10 - Apparent digestibility coefficients (ADC) for dry matter (ADDM) and crude protein (ADCP) using $\mathrm{Cr}_{2} \mathrm{O}_{3}$ and AIA as inert marker, for shrimp tested over 7weeks.

\section{CHAPTER 3}

Table 01 - Formulation and proximate composition of maintenance diet used during the nursery phase for fingerling cobia Rachycentron canadum (\%, as is basis).

Table 02 - Proximate and amino acid composition of the main ingredients used in the experimental diets for cobia Rachycentron canadum fed for 10 weeks $(\%$, as is basis).

Table 03 - Formulation and proximate composition of the experimental diets and commercial feed. 
Table 04 - Formulation and proximate composition of the six experimental diets and one commercial feed.

Table 05 - Juvenile cobia (Rachycentron canadum) growth and feed performance in the outdoor cage net system over the 10-week experimental period.

Table 06 - Apparent digestibility coefficients (ADC) for dry matter (DM) and crude protein (CP) by juvenile cobia fed the six experimental diets*.

Table 07 - Dietary (trash-fish, mainly Sardinella brasiliensis) and whole-body (initial and final) amino acid profiles of juvenile cobia (Rachycentron canadum).

Table 08 - Amino acid composition (\%, as is basis) of diet Aquamar and Commercial feed.

Table 09 - $\quad \mathrm{A} / \mathrm{E}^{\mathrm{a}}$ ratios of the amino acid composition of whole-body (initial and final) of juvenile cobia (Rachycentron canadum), and trash-fish (mainly Sardinella brasiliensis).

Table 10 - Final whole-body amino acid profile and estimative of dietary amino acid requirement of cobia, as based on carcass daily deposition ${ }^{1}$ and whole-body amino acid profile methods ${ }^{2,3}$.

Table 11 - The content of EAA $(\mathrm{g} / 100 \mathrm{~g})$ in dry matter basis to meet the requirements of EAA of cobia when fed under the conditions of $45 \%$ and $50 \% \mathrm{CP}$ in diet, $80 \%$ and $90 \%$ of apparent digestibility coefficient of crude protein, feeding rate $3 \%$ of body weight.

Table 12 - Water quality parameters over the 10-weeks indoor tank feeding trial.

Table 13 - Juvenile cobia growth and feed performance in the indoor tank system over the 10week experimental period.

Table 14 - Apparent digestibility coefficients (ADC) for dry matter (DM) and crude protein (CP) by juvenile cobia fed the six experimental diets*.

Table 15 - Quantitative essential amino acid (\%, dietary dry matter, EAA) requirements of some commercial carnivorous fish species and estimative of dietary amino acid requirement of cobia Rachycentron canadum, as based on carcass daily deposition and whole-body amino acid profile methods.

Table 16 - Whole body amino acid composition of cobia Rachycentron canadum and different fish species (expressed as \% of CP).

Table 17 - The daily intake (g/fish/day), daily tissue deposition (g/fish/day), and retained quantity (\%) of essential amino acids (EAA) of cobia Rachycentron canadum fed a high-value protein diet for 70 days. 


\section{CHAPTER 4}

Table 01 - Proximate and amino acid composition of the main ingredients used in the manufactures of the six experimental diets to juvenile Florida pompano Trachinotus carolinus fed for 45 days (\%, as fed basis).

Table 02 - Formulation and proximate composition of diets fed to juvenile Florida pompano Trachinotus carolinus for 45 days.

Table 03 - Composition of the amino acid premix included in the juvenile Florida pompano Trachinotus carolinus experimental diets.

Table 04 - $\quad$ Florida pompano Trachinotus carolinus whole body amino acid profile used as reference in the formulation of the six experimental diets (\%, dry matter).

Table 05 - Analyzed amino acid composition of the six experimental diets fed to juvenile Florida pompano Trachinotus carolinus (\%, dry matter).

Table 06 - Water quality parameters during the feeding trial.

Table 07 - $\quad$ Initial weight, final weight, survival, weight gain, feed efficiency (FE), feed conversion rate (FCR), protein efficiency ratio (PER), and specific growth ratio (SGR) of Florida pompano Trachinotus carolinus fed diets with graded levels of dietary methionine for 45 days.

Table 08 - Visceral somatic (VSI) index and hepatosomatic index (HSI) of Florida pompano, Trachinotus carolinus fed diets with different dietary methionine levels for 45 days. 


\section{GENERAL INTRODUCTION}

Aquaculture is the fastest-growing animal food production sector worldwide and is becoming the main source of aquatic animal food in human consumption. Depletion of wild fishery stocks, rising global populations, continuing demand for food fish, and international trade has driven aquaculture's tremendous expansion during the last decades - in terms of production volume and value. Global aquaculture production grew at an annual rate of $8 \%$ in the period of 2004 to 2014. In this scenario, the production of animal food by aquaculture has grown faster than any other sector of agribusiness (FAO, 2016). By 2014, aquaculture appeared to surpass capture fisheries as the larger source of seafood for human consumption, although overall wild harvests remain larger due to non-food uses such as reduction for fishmeal (FAO, 2016). The rise of aquaculture is attributed to a massive increase in productivity - knowledge and techniques from agriculture were employed to gain control of the production process (ANDERSON, 2002) - paired with substantial growth in global seafood demand (DELGADO et al., 2003). Nations and fish farmers have exploited this opportunity to meet protein needs and serve an ever growing global seafood market.

Brazil is the second largest aquaculture producer in Latin America, with rapid growth in farmed fish and shrimp production, up from close to zero in 1990 to 561,439 tonnes in 2014 (FAO, 2016). The aquaculture sector in Brazil has enjoyed very steady long-term growth, showing good growth in the sector, especially for tilapia and shrimp production (TACON, 2002). Tilapia is the major aquaculture species in Brazil and its production grew over 14\% per year from 2004 to 2014. Freshwater aquaculture accounted for over to $70 \%$ of the total national aquaculture production in 2014 (FAO, 2016). Marine aquaculture contributed 16\% to the total farmed fish production, predominantly shrimps, mussels and oysters. The private sector has shown interest in investing in cage culture of other marine finfishes and Brazil's government is supporting such initiatives to diversify the sector. Brazil has very positive conditions for the development of aquaculture. It is a country of tropical climate with a strong domestic market - largest market in Latin America. It has a large and well developed agriculture sector, occupying a special position when it comes to production of grains, and a solid feed production industry. And in addition, the country has a large supply of fresh water and areas for pond construction, there are $8.500 \mathrm{~km}$ of coastal line and 4.2 million hectares of reservoirs that can be used for aquaculture. 
Increased production of high-value aquatic species and intensification of existing culture practices, has contributed significantly to the large production and utilization of industrial aquafeed in the world. To sustain the predicted increase in the use of aquafeeds requires an intensive global research and development initiative, improvements in production technology and feeding practices. In particular, these initiatives should focus on the use of fishmeal and plant-based ingredients (TACON et al., 2011). The search for suitable and cost-effective alternative protein sources for use in industrial aquafeeds will be the most critical factor in the development of aquaculture. Fed aquaculture production, in particular, of higher trophic level finfish and crustaceans (includes marine shrimps, salmonids, marine finfishes, eels) are largely dependent upon capture fisheries for the supply of their major dietary source of protein and lipids. Aquaculture feeds require fishmeal and oil made from pelagic, marine fish and products from agriculture as ingredients. The major concern related to ingredients is the large amount of fishmeal and oil used. Various by-products of animal and plant-based are alternate and available ingredients to replace fishmeal use, but the nutritive value of such alternatives should be assessed. Further, production efficiency of fed species has improved. For example, the use of fishmeal and fish oil per unit of farmed fish produced has declined substantially as reflected in the progressively declining inclusion levels of average dietary fishmeal and fish oil within compound aquafeeds (TACON; METIAN, 2008). Although current discussion on the use of marine products as aquafeed ingredients focuses on fishmeal and fish oil resources, the sustainability of the aquaculture sector is more likely to be linked with the sustained supply of terrestrial animal and plant proteins, oils and carbohydrate sources for aquafeeds. This is because a significant proportion of aquaculture production is of the non-carnivorous species. Thus, aquaculture producing countries should place more emphasis to maximize the use of locally available feed-grade ingredient sources and use nutritionally sound and safe feed ingredients that can be sustainably produced and grow with the sector (TACON et al., 2011).

Therefore, the main objective of this thesis was to evaluate the feeding and nutrition of tropical farmed fish and shrimp, always targeting its applicability to aquaculture farming. Specifically, in Chapter 1, a study of the actual panorama of aquafeed quality for the two most valuable aquaculture species cultured in Brazil (tilapia Oreochromis niloticus and shrimp Litopenaeus vannamei) was conducted to assess proximate nutrient composition, physical water 
stability, in vitro degree of protein hydrolysis (DH), and evaluation of near-infrared spectroscopy (NIRS) with preliminary tests on soybean meal samples. Chapter 2, evaluated the acid-insoluble ash (AIA) as inert marker to determine apparent digestibility coefficient (ADC) of dry matter and crude protein with Litopenaeus vannamei fed practical and commercial diets, to ensure the applicability of the technique to the field (farms); and assess the influence of feed preparation method (cold pelleted vs. industrial extruded) in the ADC of dry matter and crude protein with Litopenaeus vannamei fed commercial diets. Chapter 3 developed management and feeding protocols for cobia Rachycentron canadum produced in floating net cages and fed with practical and commercial diets; analyzed the diet and whole body amino acid composition of cobia Rachycentron canadum fed a high-quality protein diet in order to estimate their EAA requirements, based on the amounts of each amino acid retained in the carcass; compared the estimated EAA with the present estimation values for cobia Rachycentron canadum and other marine carnivorous fish species; evaluated growth performance, liver histopathology, and apparent digestibility coefficients for dry matter and crude protein, of cobia Rachycentron canadum fed commercial and fishmeal-based diets partially replaced by alternative feedstuffs commercially available in the Brazilian market place. Chapter 4 evaluated the total sulfur amino acid requirement of juvenile Florida Pompano Trachinotus carolinus, using combinations of various soybean protein products in order to develop cost-effective and environmentally-friendly diets. Results were discussed in each chapter, and as illustrative material, photographs of experimental systems, procedures, equipment, and facilities used for the studies were presented.

This study was conducted with financial support of the Coordination for the Improvement of High Level Education Personnel (CAPES), under the supervision of the professor Dr. Daniel Lemos and Dr. Albert G. J. Tacon. This thesis has been written following the guidelines for thesis and dissertations of the University of São Paulo based on Brazilian Standards (ABNT) described in: "Diretrizes para apresentação de dissertações e teses da USP: documento eletrônico ou impresso - Parte I (ABNT - Associação Brasileira de Normas Técnicas)”. 


\section{References}

ANDERSON, J. L. Aquaculture and the future, Marine Resource Economics, v. 17, p. 133-152. 2002.

DELGADO, C.; WADA, N.; ROSENGRANT, M.W.; MEIJER, S.; AHMED, M. Fish to 2020: supply and demand in changing global markets, IFPRI, Washington. 2003.

FAO. Fisheries and aquaculture software. FishStat $\mathrm{J}$ - software for fishery statistical time series. In: FAO Fisheries and Aquaculture Department [online]. Rome. Released March 2016. Available at http://www.fao.org/fishery/statistics/software/fishstatj/en. 2016.

TACON, A. G. J.; HASAN, M. R.; METIAN, M. Demand and Supply of Feed Ingredients for Farmed Fish and Crustaceans: Trends and Prospects. FAO Fisheries and Aquaculture Technical Paper No. 564. FAO, Rome, p. 87. 2011

TACON, A. G. J. Thematic Review of Feeds and Feed Management Practices in Shrimp Aquaculture. Report prepared under the World Bank, NACA, WWF and FAO Consortium Program on Shrimp Farming and the Environment. Work in Progress for Public Discussion. Published by the Consortium. 69 pp. 2002.

TACON, A. G. J.; METIAN, M. Global overview on the use of fish meal and fish oil in industrially compounded aquafeeds: trends and futures prospects. Aquaculture, v. 285, p. 146-158. 2008. 


\section{CHAPTER 1}

Assessing the quality of commercial aquafeeds for Nile tilapia Oreochromis niloticus and Pacific white shrimp Litopenaeus vannamei farmed in Brazil: proximate composition, water stability, in vitro protein digestion, and use of near-infrared spectroscopy (NIRS). 


\section{Preface}

This chapter contains the result of my research undertaken at the Instituto Oceanográfico of Universidade de São Paulo, and field visits to commercial fish and shrimp grow-out farms located in the Southeast and Northeastern farming areas in Brazil. Part of the information contained in this chapter has been presented in international conferences, as follow:

RAGGI, T.; LEMOS, D.; TACON, A. G. J. The use of near infrared spectroscopy (NIRS) and in vitro protein digestion to predict the nutrient digestibility of feed ingredients for shrimp, Litopenaeus vannamei. In XII International Symposium on Aquaculture Nutrition. Villahermosa, Tabasco, Mexico. 20 - 22 November, 2013.

RAGGI, T.; LEMOS, D.; TACON, A. G. J. Assessing commercial aquafeeds for Nile tilapia Oreochromis niloticus and Pacific white shrimp Litopenaeus vannamei farmed in brazil: proximate nutrient composition, physical water stability and in vitro protein digestion. In Aquaculture 2013, World Aquaculture Society Meeting, Nashville, Tennessee, USA. 21 - 25 February, 2013. 


\section{Abstract}

A study of the actual panorama of aquafeed quality for the two most valuable aquaculture species cultured in Brazil was conducted to assess proximate nutrient composition, physical water stability, in vitro degree of protein hydrolysis (DH), and evaluation of near-infrared spectroscopy (NIRS) with preliminary tests on soybean meal samples. Feed samples of tilapia Oreochromis niloticus $(\mathrm{n}=16)$ and shrimp Litopenaeus vannamei $(\mathrm{n}=19)$ were collected from commercial grow-out farms located in the Southeast and Northeastern farming areas in Brazil, analyzed for proximate composition (moisture, crude protein, crude fiber, ether extract, total ash, nitrogen-free extract and gross energy), and then compared with the declared contents from the feed manufactures. Pellets dry matter losses (DML) over different water conditions were investigated according to feeding environment in pond and cage farming systems for shrimp and fish, respectively. The $\mathrm{DH}$ of the feed samples was assessed in vitro with standardized hepatopancreas (shrimp) and stomach + intestine (fish) enzymes extracted from commercially farmed animals. A web-based questionnaire was also elaborated to identify the applications of NIRS in the aquafeed industry, followed by a preliminary test with soybean meal samples, in order to predict the DH values. Proximate compositions between the analyzed feed were mostly consistent with the declared values from the manufacturers. The average of total DML for shrimp feeds was influenced by salinity, and was significantly higher at 5ppt than at 35ppt. The observed DH for the tilapia feeds varied from 3.7 to $5.5 \%$, and for the shrimp feeds varied from 3.1 to $4.4 \%$. The in vitro $\mathrm{pH}$-stat species-specific method to determine the $\mathrm{DH}$ showed to be a useful tool to evaluate the practical ingredient soybean meal and feed quality. Based on the NIRS survey, the technique can be used in many applications throughout the aquafeed industry, but in Brazil it is still mainly being used for routine proximate analysis. The preliminary NIRS test with 34 soybean meal samples showed a good correlation coefficient $\left(\mathrm{R}^{2}=0.92\right)$ with the predicted $\mathrm{DH}$ results. NIRS showed to be an efficient tool for rapidly assessing feed quality in terms of protein degree of hydrolysis, and it can be used to connect the advanced scientific knowledge generated by scientists in laboratories with the application in the field. Feed is the most important input in increasing aquaculture production and profits. 


\subsection{Introduction}

\section{Tilapia and shrimp farming in Brazil}

Nowadays, influenced by the rapid population growth on the planet, demand for animal protein as a food source is growing rapidly. Due the increase of fishing achieved with a rapid evolution of technology and increasing numbers of boats, the fishing stocks, before considered inexhaustible, are suffering an increasing depletion. Thus the extractive fishing world is today, close to its maximum potential (FAO, 2016). In this scenario, the production of animal food by aquaculture has grown faster than any other sector of agribusiness (FAO, 2016). In Brazil, aquaculture is showing good growth in the sector, especially for tilapia and shrimp production (TACON, 2002). The production relies very heavily on inland aquaculture of finfish while their potential for production of marine finfish species remains largely unexploited. Global aquaculture production grew at an annual rate of $8 \%$ in the period of 2004 to 2014 . Tilapia is the major aquaculture species in Brazil and its production grew over 14\% per year in that same period. Despite the highest average annual growth in production, Brazilian aquaculture is still far behind the production levels attained by the poultry, beef and pork industries (FAO, 2016).

Freshwater fish aquaculture in Brazil was estimated at 474,000 metric tones ( $\mathrm{mt}$ ) in 2014 (MPA/IBGE, 2015). Tilapia was the major cultured species at 198,664 thousand $\mathrm{mt}$, followed by round fishes, estimated at 198,627 thousand MT. Adding to these numbers a production of $65,018 \mathrm{mt}$ of marine shrimp, plus 22,092 $\mathrm{mt}$ of mussels and oyster, and an estimated 77,037 $\mathrm{mt}$ of other aquatic animals, Brazilian aquaculture production was near 561,439 mt in 2014 (Figure $1)$. 
Major aquaculture products in Brazil (mt, \%)

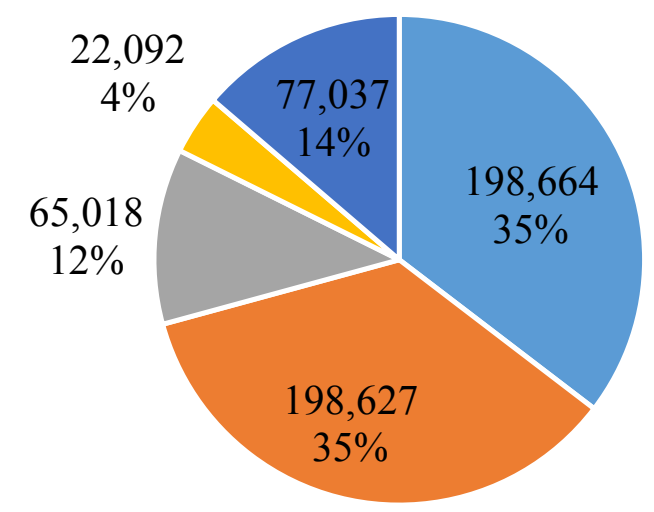

- Tilapia (O. niloticus)

- Round fishes*

- Shrimp (L. vannamei)

- Mussels and oysters

- Other species

Figure 1 Estimates of fish, shrimp and other aquatic organisms farmed in Brazil in 2014 (MPA/IBGE, 2015).

*Tambaqui (Colossoma macropomum), pacu Piaractus mesopotamicus, tambacu C. macropomum x P. mesopotamicus, pirapitinga Piaractus brachypomus, and patinga P. mesopotamicus x P. Brachypomus.

Brazil is a significant global producer of grains and livestock, which is beneficial to aquafeed industry. Despite the limited supply of fishmeal and fish oils, animal feed manufacturers in Brazil have good quality animal meals, derived from the processing of poultry, pork and beef byproducts. Plant materials, especially corn, sorghum, soybean (whole and meal), wheat bran, cotton seed meal, rice middlings and brans, among others, are also widely available and at very competitive prices. The processing of aquaculture byproducts into fishmeal, fish oil and protein concentrates also contribute to the aquafeed industry and will be an even more important source of nutrients to aquafeed as the sector progresses. These local commodities can supply the necessary protein sources the aquafeed production require. As the vast grain producer with the large potential for further growth, Brazil owns the advantage in producing aquafeed. According to the latest estimates provided by Brazil's Feed Industry Association (SINDIRAÇÕES, 2015), the total animal feed production in 2014 was 67.4 million tones. Fish feed production in 2015 was estimated in 835,000 tonnes, up 10.7\% from previous year, while shrimp feed output grew 5\% to 105,000 tonnes (Figure 2). Total aqua feed production grew $10.1 \%$ to 940,000 tonnes in 2015. The main volume of aquafeed produced in Brazil are for the grow-out of omnivorous fishes (floating pellets from 4 to $10 \mathrm{~mm}, 28$ to $32 \%$ crude protein and 4 to $8 \%$ fat). 


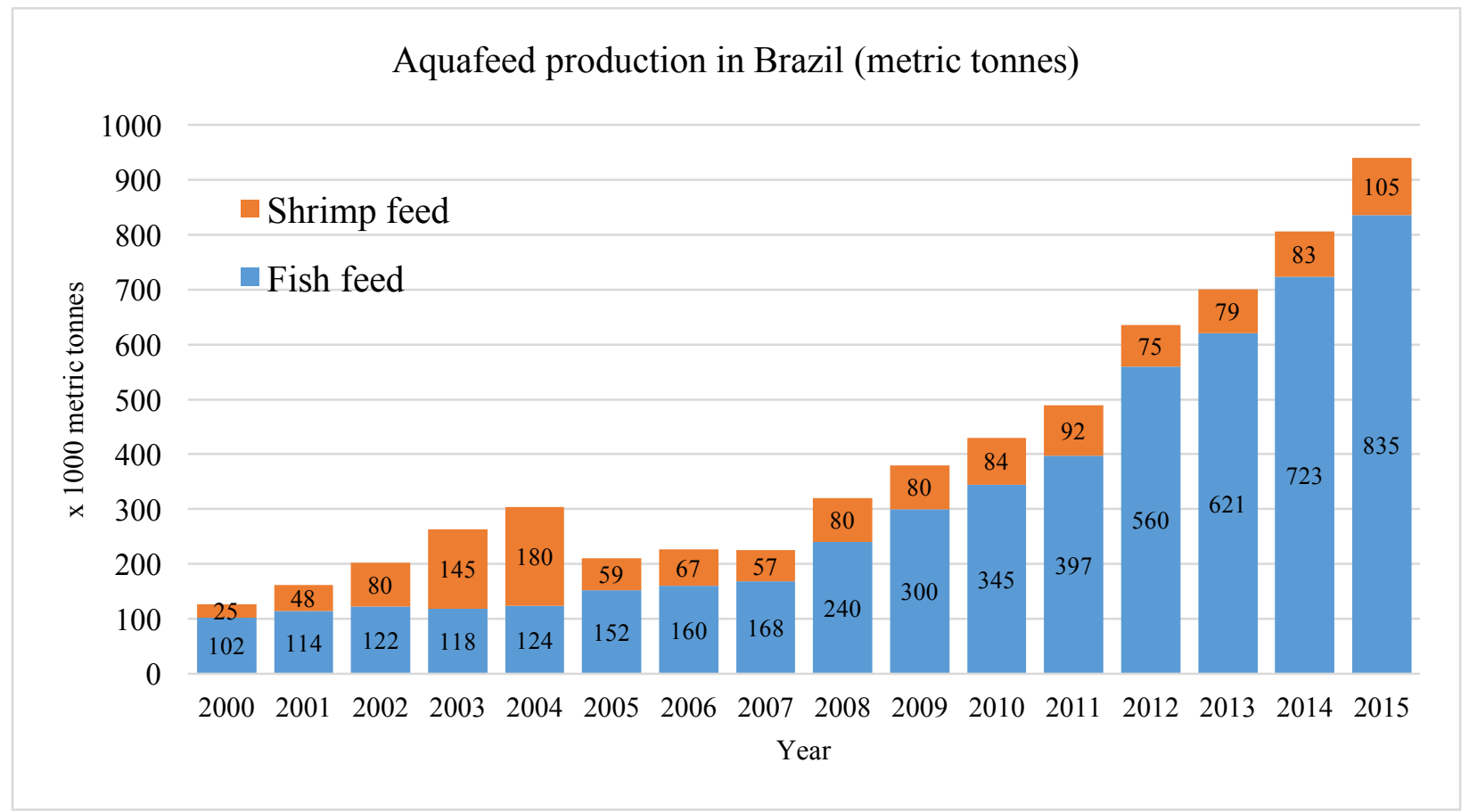

Figure 2 Production of shrimp and fish feeds in Brazil on the last fifteen years (SINDIRAÇÕES, 2015).

Tilapia is the second most cultured fish in the world after carps. The total global tilapia production accounted for 4.82 million tons in 2013, with a farm-gate value of US\$ 8.25 billion (FAO, 2016), and the production continues to grow. Tilapia's popularity is due to its hardiness and omnivorous feeding characteristics, which makes it suitable for farming under less optimal environmental conditions (ROJAS; WADSWORTH, 2007). Seventy-two \% of tilapia production is in Asia, particularly in China and Southeast Asia, 19\% is in Africa and 9\% is in America (FAO, 2016). Tilapia is farmed both in ponds and cages in semi-intensive and intensive systems. In recent years, cage farming has been spread all over the world because it features a relatively lower investment requirement compared to ponds and raceways (ROJAS; WADSWORTH, 2007), is quick and easy to start up and enables more production cycles per year (BALIAO; DOSADO, 2011).

In Brazil, the majority of fish production is derived from continental inland aquaculture, with tilapia representing the most farmed aquatic species. Brazil holds about 10 million ha of freshwater in dams, rivers, lakes and man-made reservoirs. Floating cages have become the most popular system for rearing tilapia in Brazil in areas with suitable water quality, flushing rates and water depth. The production of tilapia was 198,664 tons in 2014, which corresponded to over 
$35 \%$ of the fish production (MPA/IBGE, 2015). Tilapia cage farming in Brazil can be considered as a relatively new production system, once this production model emerged in the first decade of the $21 \mathrm{st}$ century. Most cages are $6-18 \mathrm{~m}^{3}$, in which the most cultured species is Nile tilapia, Oreochromis niloticus. Each fish spends five to seven months to reach $800 \mathrm{~g}$, then they are harvested and sold whole, or processed into skinless, boneless filets. The usual harvest density adopted in Brazil ranges from 50 to $100 \mathrm{~kg}$ of fish per $\mathrm{m}^{3}$. (GIBTAN et al., 2008; CHAKRABORTY et al., 2010; NUNES, 2012).

Caged-farm tilapia in Brazil feeds exclusively on commercial extruded floating diet, which is produced by medium and large factories. Feed protein content, pellet size and suggested feeding rates may vary according to the stage and farming system. Fish feeds tend to be high in protein content at initial stages and thereafter decreases as fish attain larger sizes. Grow-out and finishing feeds are usually $32 \%$ in protein content and may represent up to $80 \%$ of all feeding costs at a cage farm. As such, feed management is critical to the economics of a cage operation. To determine maximum ration sizes, farmers usually follow suggested rates from commercial feeding tables. However, rations are adjusted daily depending on fish appetite. In small-volume cages, rations are never delivered in full amounts. Initially, fish can be fed only half of the calculated ration. The remainder is offered if the first ration is fully consumed within 30 minutes after distribution. After this period, uneaten feed can be oversaturated with water, and the heavier pellets exit the confined feed area, leading to feed loss. Cage operations equipped with walkways allow more detailed inspections of feed consumption. They facilitate feed handling and storage, and promote feed delivery to as often as 8 times/day during grow-out compared to three times when distributed from feed boats. Walkways also allow the collection of fish debris and more frequent clean-up of feeding rings or net curtains (NUNES, 2012).

The introduction of the exotic species Litopenaeus vannamei in Brazil, popularly known as whiteleg shrimp, permitted a rapid growth of this culture from the 90's (BORGHETTI et al., 2003; ABCC, 2004). The development of the Brazilian shrimp farming industry, especially in the Northeastern region, is associated with the existence of extensive coastal areas connected to estuaries where are suitable for shrimp farming, favorable climate and soil conditions, as well the availability of reproduction technology and a growing demand for shrimp products (MOLES; 
BUNGE, 2002). The production of shrimp was 65,018 tons in 2014, which corresponded to over $12 \%$ of the total aquaculture production (MPA/IBGE, 2015).

Feed is a primary source of macronutrients for shrimp and a major source of pollution in pond effluent (TACON; FORSTER, 2003). Protein is an important component of shrimp feed, contributing a substantial portion of the manufacturing cost (KURESHY; DAVIS, 2002). With the recent trend in shrimp farming intensification under limited discharge, the use of suitable feed ingredients, feed formulations and feeding practices are key factors affecting the viability of these systems. In contrast to terrestrial farm animals and farmed fish where compound feeds can be fed on a visual basis according to the appetite of the animals or to a preset feeding level, pond-raised shrimp are not directly visible to the farmer during feeding, and as such, animals have to be fed 'in the dark'. As a consequence, compound shrimp feeds are usually fed by farmers that varies the daily feeding rate based on shrimp body weight, an estimate of the total shrimp biomass present in the pond or tank, and apparent consumption observed by using feeding trays. The feed usually is applied by hand or mechanically several times daily over an 8 to 12 hour working day (TACON et al., 2013).

At the shrimp farm level, feed continues to be delivered exclusively in feeding trays or by manual broadcasting. Although some farms have invested in mechanical blowers and automatic feeders, feeding exclusively in feeding trays remains the most common feeding method. In the grow-out phase, shrimp reach commercial sizes of 7 to $20 \mathrm{~g}$. During this 70 to 150 -day period, shrimp are fed two to four times daily using pelleted feed distributed from fixed trays by workers in kayaks. The leftover feed is routinely checked and removed, thus avoiding its degradation, which can cause stress and adversely impact the grow-out environment. Moreover, control of physical and chemical parameters such as temperature, dissolved oxygen, salinity, $\mathrm{pH}$, nitrite and ammonia levels, and the biological parameters phytoplankton, zooplankton and zoobenthos allows the adoption of corrective measures that ensure an ecologically balanced environment. In addition, the use of probiotics (feed and water) as a biosecurity tool as well as nutritional control is becoming part of the management routine of hatcheries, nursery tanks and grow-out ponds in Brazil. Weekly biometrics and presumptive analysis generate information on shrimp performance as well as corrective or preventive measures during the grow-out process. Depending on these analyses, the harvesting process may begin, preferably at nighttime due to 
the movement of the shrimp and the milder temperatures, reducing stress and improving the final quality of the shrimp.

\section{Pellet water stability}

The high productivity achieved with the intensification of the systems and farm techniques, can also result in high environmental costs. The intensive use of natural resources and high production of nutrients can make the fish and shrimp farming a significant source of eutrophication (BORGHETTI et al., 2003; LACERDA et al., 2006). The success of a farm is intrinsically related to the performance and handling of the feed in the culture system. Corresponding to over $50 \%$ of the cost of operating a fish and shrimp farm (AKIYAMA et al., 1992), the feed should have nutritional and physical characteristics that allow proper growth and reduced nutrients losses in the water. High amounts of nutrients in the water can induce biological contamination of the system, leading to lower rates of growth, inefficient feed conversion and poor survival of the organisms (OBALDO et al., 2002). Nutritional strategies to minimize the impact of aquaculture on aquatic environments include: manipulation and formulation of diets selecting more digestible raw materials; control on feed granulation processes; adoption of more effective feed management practices for particular fish and shrimp species; recovery of unconsumed feeds; and selection of animal species and strains with higher feed efficiency and better nutrient utilization (AMIRKOLAIE, 2011). Thus, the legislative regulation of feed composition also can be an important mechanism to regulate and reduce the environmental impacts of aquaculture, considering the complexity of the biological processes of animal growth and nutritional requirements.

High pellet water stability is defined as the retention of pellet physical integrity with minimal disintegration and nutrient leaching while in the water until consumed by the animal. Many finfishes such as tilapia and catfish are instant feeders. For these fish, the pellets need to be stable in the water for only a few minutes, while the shrimp needs more time of water stability (TACON, 1996). In our shrimp digestibility trial (Chapter 2), using automatic feeders, it was observed that shrimp catch the pellets in around 5 minutes. During the last decade, there has been a marked increase in the use of extruded diets for feeding fish. These diets have superior water stability, better floating properties and a higher energy than pelleted diets (HILTON et. al., 1981; 
JOHNSEN; WANDSVIK, 1991; AMMAR, 2008). On the other hand, the manufacturing costs for the extruded diets are higher comparing with pelleted diets. In Brazil, commercial tilapia feeds are mainly extruded, while shrimp diets are conventionally steam pelleted (few manufacturers producing extruded shrimp feeds).

Since shrimp are marine animals with slow eating habits compared with fish (JUSSILA; EVANS, 1998; AGUIRRE-GUZMAN et al., 2002; OBALDO et al., 2002), the problems mentioned above become even more important. The long stay of feed in water (because of the use of feeding trays and also feeding logistic) can introduce dissolved nutrients into the culture system and also change the nutritional balance of the food (GADIENT; SCHAI, 1994), which can lead to an inefficient supply of vitamins and nutrients. Thus, evaluation of quality of diets for marine shrimp has been the subject of several studies (COUSIN et al., 1996; LEMOS et al., 2004). The stability of a diet is dependent on factors such as technology and manufacturing processes, the types of ingredients used, type and purity of binders, particle size and moisture content. Environmental characteristics such as temperature and salinity also influence the stability of feed (LIM; DOMINY, 1990; FLOWERS; MARTINES, 1993; OBALDO et al., 2002; PEARCE et al., 2002; RUSCOE et al., 2005). According to AKYIAMA; POLANCO (1997), shrimp feed attractability proprieties are lost in about $2 \mathrm{~h}$ after being introduced into the water.

In the manufacturing process, the processing temperature is a very important factor for the stability of the feed, determining the degree of gelatinization of the binder, that is, how much it can group the particles present in the feed, generating more stability (PEARCE et al., 2002). Currently, starch is required to bind the ingredients in order to form a durable pellet. At the same time, starch is a requirement for expansion and floating of pellet. Unfortunately, expansion can result in pellets with a weaker overall structure, even at high degree of gelatinization (AARSETH et al., 2006). Water soluble and hygroscopic ingredients weaken pellet structure in water, allowing components to separate and making the feed only partially accepted. The stability studies of feeds for aquaculture are reported in the literature, especially with works that evaluate the differences on quality and formulations of feeds (PEARCE et al., 2002; RUSCOE et al. 2005). 
In vitro degree of protein hydrolysis (DH)

To predict the nutritional value of compound feeds and raw materials is one of the main goals of fish nutritionists and feed formulators and, to be adequate at industrial level, assessment methods should be fast, precise and reproducible, which has motivated the development of in vitro methods (YASUMARU; LEMOS, 2014; MOYANO et al., 2014). Current methods to determine protein digestibility involve in vivo trials, and the collection and analysis of feeds and feces (FORSTER et al., 2003; SMITH; TABRETT, 2004). Because of limitations in output (time-consuming and expensive) and the need for specialized facilities for animal rearing, rapid and practical in vitro methods are desirable as a responsive input to be considered in feed manufacturing (TACON, 1996; LAZO; DAVIS, 2000). Most of the available in vitro tests used in aquafeeds follow or adapt methodologies routinely used for warm-blooded terrestrial livestock including reactions with purified commercial enzymes (DIMES; HAARD, 1994). However, the non-specific nature of these enzymes has been a major limiting factor to consistent application into nutritional assessments for fish and shrimp species (DIMES et al.1994; EZQUERRA et al., 1997; LEMOS et al., 2004). An in vitro $\mathrm{pH}$-stat routine to determine protein digestibility using species-specific shrimp digestive enzymes is a promising alternative to assess the protein quality of ingredients and finished feeds (LEMOS; NUNES, 2008; NATES; TACON, 2005). Moreover, feed characterization is becoming increasingly significant for aquafeeds not only by providing the greatest differential between feed costs and product sales but also by reducing unfavorable environmental impacts (GIVENS; DEAVILLE, 1999; SUGIURA, 2000).

Previous studies using the in vitro $\mathrm{pH}$-stat determination of degree of protein hydrolysis (DH) have reported its potential to differentiate feedstuff quality and also to predict ingredient protein digestibility (DIMES et al., 1994; LEMOS et al., 2009; TIBBETTS et al., 2011; YASUMARU; LEMOS, 2014). The $\mathrm{pH}$-stat application to determine in vitro digestion with species-specific enzymes has shown to be a fast and precise method with reported use for different aquatic species such as fish (DIMES et al., 1994; TIBBETTS et al., 2011; YASUMARU; LEMOS, 2014), shrimp (EZQUERRA et al., 1998; LEMOS et al., 2009), and mollusks (AGUILAR et al., 2012). 
Near-infrared reflectance spectroscopy (NIRS)

Economical use of available feed ingredients is fundamental to profitability of any livestock industry, including the aquaculture sector. To effectively utilize limited feed resources, it is essential that we identify those factors that can influence ingredient quality and subsequently develop techniques for the assessment of all ingredients prior to inclusion in compound feeds. To date, our ability to achieve this has been restricted, with techniques available to nutritionists and feed manufacturers limited to measurement or prediction of chemical composition of feed ingredients, or literature values based on in vivo measurements. Given the variation that exists in the nutritional and physical quality of feed ingredients, this approach is far from adequate and alternative techniques for the rapid assessment of nutritional quality must be identified.

Near infrared spectroscopy (NIRS) is a tool that can be used for process control, quality assessment, identification of raw materials and process by-products, and for quantitative chemical analysis of complex mixtures (HYMOWITZ et al., 1974; RINNE et al., 1975). NIRS is based on light absorption at near-infrared wavelengths by the molecules constituting the sample, is a nondestructive, rapid, and predicative technique. NIR spectroscopy utilizes the spectral range from 780 to $2,500 \mathrm{~nm}\left(12,500\right.$ to $\left.4,000 \mathrm{~cm}^{-1}\right)$ and provides much more complex structural information related to the vibration behavior of combinations of bonds. The record of NIR region of the electromagnetic spectrum involves the response of the molecular bonds $\mathrm{O}-\mathrm{H}, \mathrm{C}-\mathrm{H}, \mathrm{C}-\mathrm{O}$ and N-H. These bonds are subject to vibrational energy changes when irradiated by NIR frequencies, and two vibration patterns exist in these bonds including stretch vibration and bent vibration. The energy absorption of organic molecules in NIR region occurs when molecules vibrate or is translated into an absorption spectrum within the NIR spectrometer. The whole measurement processing generally consists of the following several steps: (1) spectral data acquisitions; (2) data pre-processing to eliminate noises and baseline shift from the instrument and background; (3) to build calibration models using a set of samples with known analyzed concentration obtained by suitable reference methods; and (4) to validate the models using another set of samples without the calibration set (CEN; HE, 2007).

NIRS technique is often presented as one of the most suitable approaches for on-line quality control of agricultural products (KAWASAKI et al., 2008). Many studies indicate that 
NIRS is an efficient first-line screening tool for monitoring the quality and safety of feed ingredients and feed mixtures. It is a multi-analytical technique allowing several factors to be predicted simultaneously. Once calibrated, the NIR spectrometer is simple to use and operate. The key to managing nutritional variability lies in gaining as robust-as-possible data on the chemical composition of the raw material prior to its use in a feed. NIRS has been used extensively to measure the crude compositional characteristics of feed grains prior to their use for some time. Modern NIRS equipment can make a range of compositional evaluations in a manner of seconds. The application of NIRS for the assessment of the nutritional quality of feed ingredients for aquaculture species is not as advanced as it is for other monogastrics (e.g. pigs and poultry). Some progress has also been made towards measuring digestible nutrient and energy parameters from some grain varieties (VAN BARNEVELD et al., 1998).

NIRS combined with chemometric calibration algorithms has been used for more than 30 years in feed analysis, mainly to determine moisture, crude protein, and other major nutrients. In 1978, RUBENTHALER; BRUINSMA first developed successfully a NIRS calibration for the lysine content in wheat and barley. DYER; FENG (1997) assessed that besides proximate analysis NIRS can also predict energy contents and amino acids accurately and that this technique will improve feed formulation and quality management in the feed industry tremendously. During the past years, in fact, NIRS has become a major tool for feedstuff evaluation, including amino acids.Positive attributes of NIRS include: a non-destructive method, simple to use, minimal sample preparation, no reagents, no waste, low cost per sample, instant analysis, high reliability, safety and timeliness of analysis, low maintenance cost, mobile analysis, analysis and data transfer through satellite networking of remote instruments is possible, low inter- and intra-laboratory variation and it is eco-friendly (GIVENS; DEAVILLE, 1999). As with any scientific innovation, there are also certain disadvantages of NIRS. The main disadvantages are the need for high-precision and expensive spectroscopic instruments, dependence of time-consuming and laborious calibration procedures, and complexity in the choice of data treatment. There can also be difficulties in the transfer of calibrations between instruments. It is typically used as a secondary analytical method. Separate spectra for each ingredient and feed group must be developed. There is weak sensitivity to minor constituents. 
Fineness of samples and storage temperature also plays a vital role in determining the precision of the analysis. There is a reasonable initial investment for the NIRS equipment. 


\subsection{Materials and Methods}

Farming areas

A total of 14 farms (5 of tilapia and 9 of shrimp) was surveyed throughout São Paulo and Rio Grande do Norte states (Figure 3).

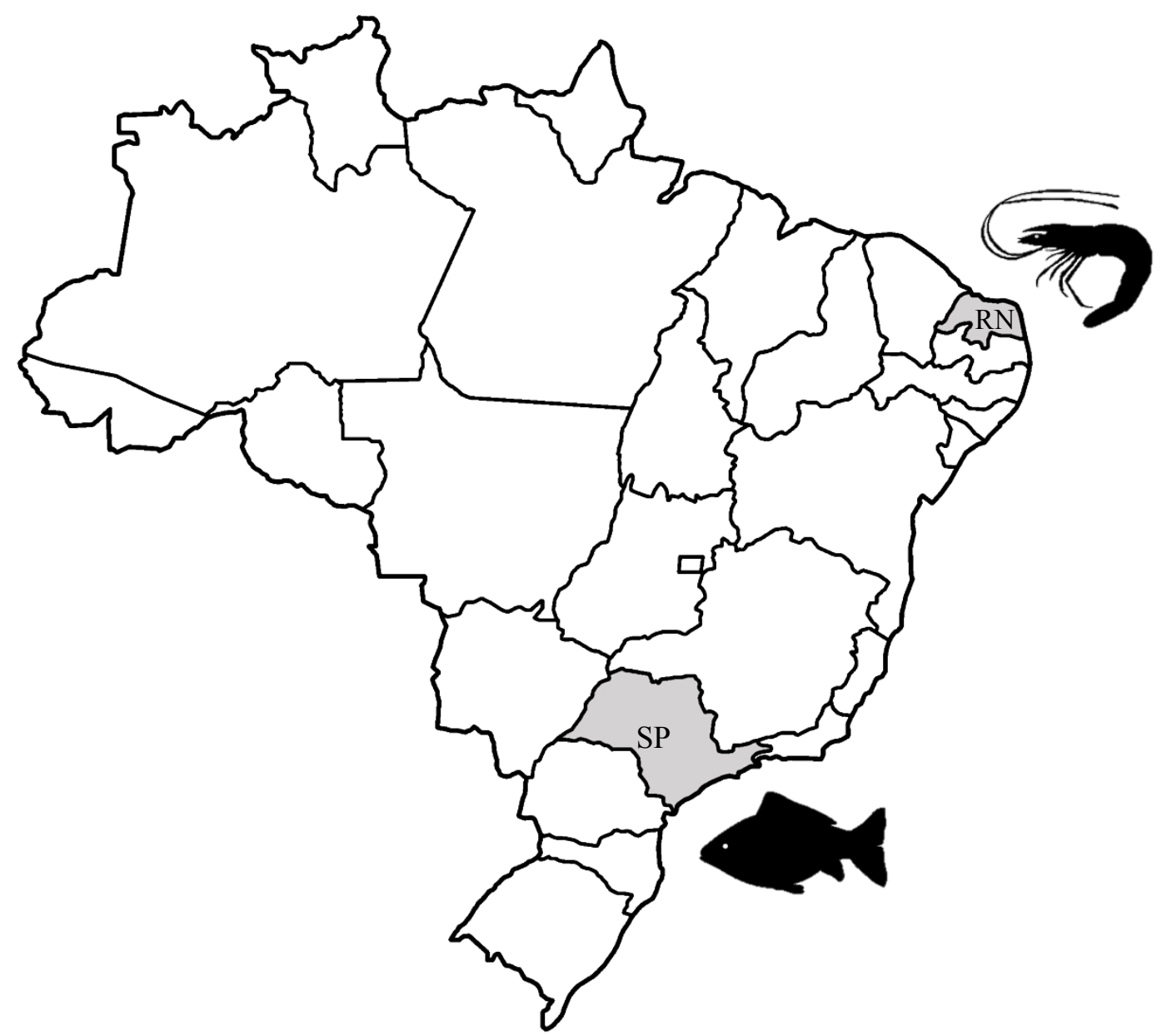

Figure 3 Tilapia and shrimp farming surveyed states: São Paulo (SP) and Rio Grande do Norte (RN).

The tilapia farms were situated in the cities of Santa Fé do Sul and Buritãma, located in the northwestern part of the State of São Paulo (Figure 4). This area has a competitive advantage compared to other regions due to favorable weather and water temperature, clean water from 
three rivers and proximity with large consumer markets and universities dedicated to technology development and research. Some of these farmers are set up as cooperatives by governmental or semi-governmental agencies. Only tilapia cage farms were visited and sampled. Feeds collected from surveyed farms were therefore considered representative of the many tilapia farms distributed in Brazil.

The visited shrimp farms were distributed in the Rio Grande do Norte state, mainly in the city of Canguaretama. The majority of Brazil's shrimp aquaculture production is concentrated in the Northeastern region of the country. The climate, characterized by stable temperatures (between 22 and $30^{\circ} \mathrm{C}$ ) and low precipitation throughout the year, is one of the main factors that support shrimp farming in that region.

\section{On farm feed samples collection}

A total of 35 samples of commercial fish $(n=19)$ and shrimp $(n=16)$ feeds were collected during the field survey. Around 500g of each feed was sampled and stored in a sealed plastic bag, prior to freezing. Only grow-out feeds were targeted, and pictures of the labels (Figure 6) were taken from each feed bags, for comparison with the actual proximate analysis. 


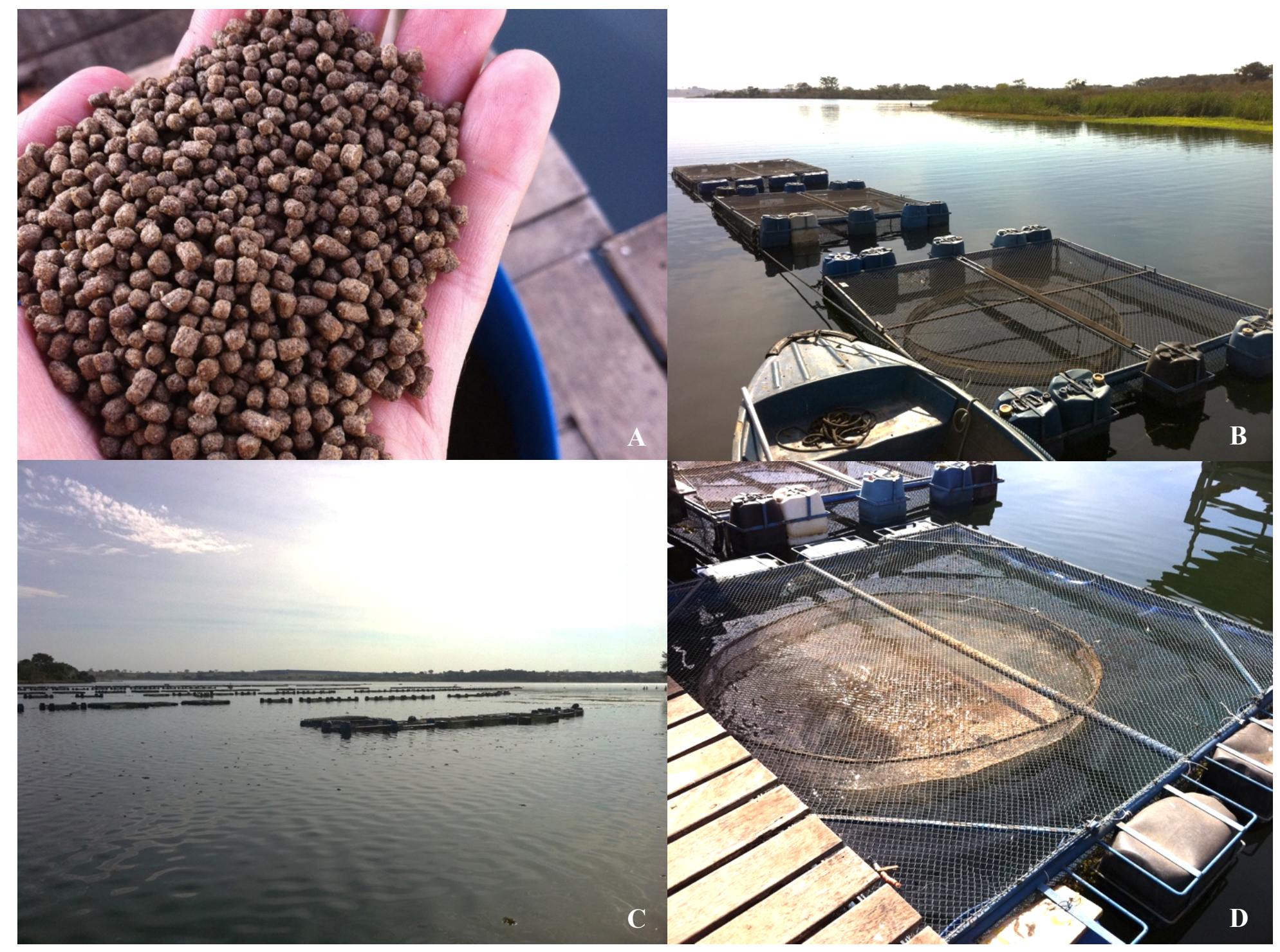

Figure 4 Animal are fed exclusively with extruded floating feeds (A). Overview of the tilapia farms located in the cities of Buritãma and Santa Fé do Sul, SP (B). Intensive cage system is distributed in the reservoirs $(\boldsymbol{C})$. Floating cages equipped with feeding ring $(\boldsymbol{D})$. 


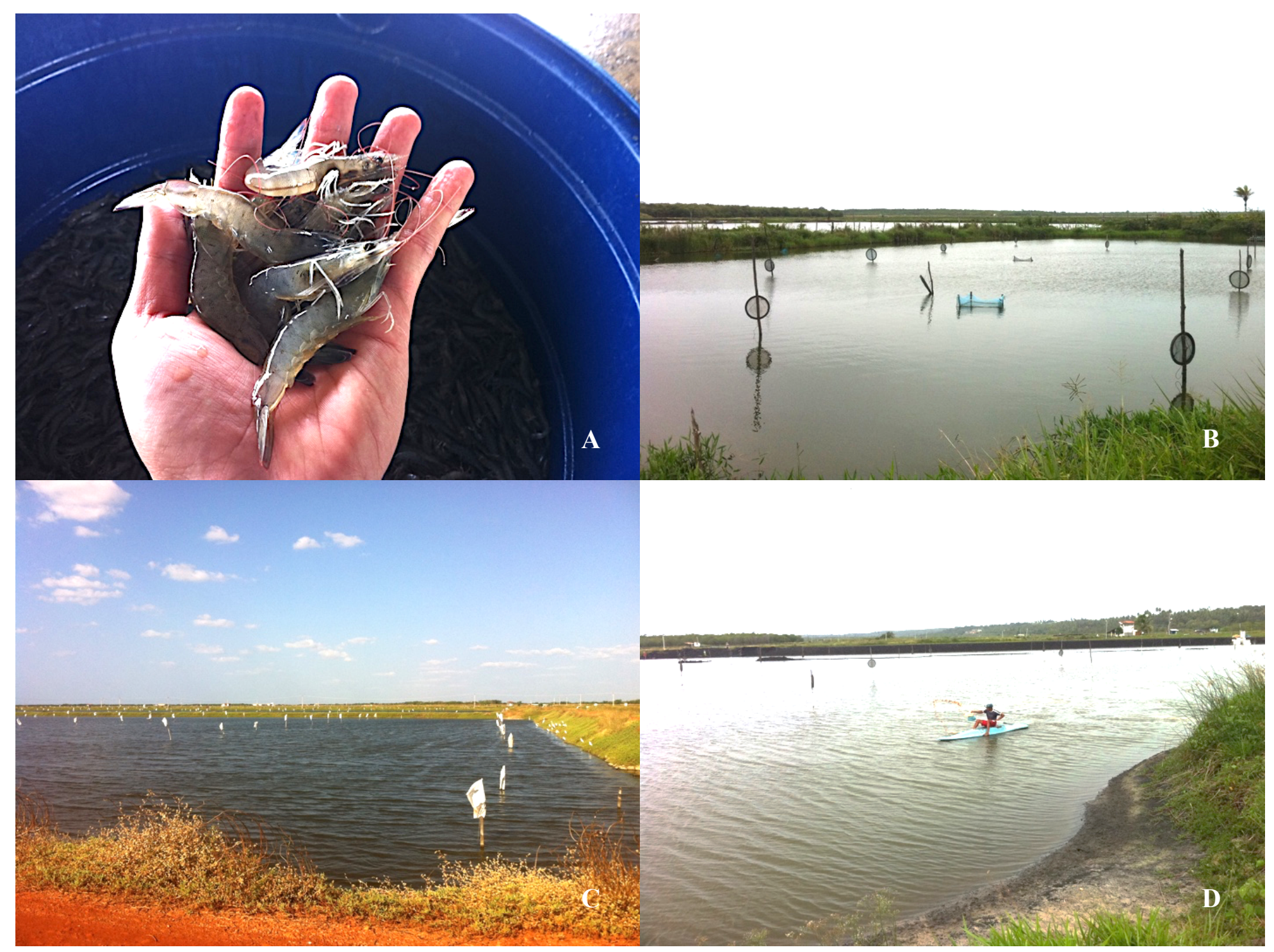

Figure 5 Shrimp farms located in the Rio Grande do Norte, RN. Commercial size is between 10 to $15 \mathrm{~g}(\mathrm{~A})$. Shrimp are fed two to four times daily using pelleted feed distributed from fixed trays $(\boldsymbol{B})$ by workers in kayaks $(\boldsymbol{C})$. The largest shrimp farm in Brazil (D). 

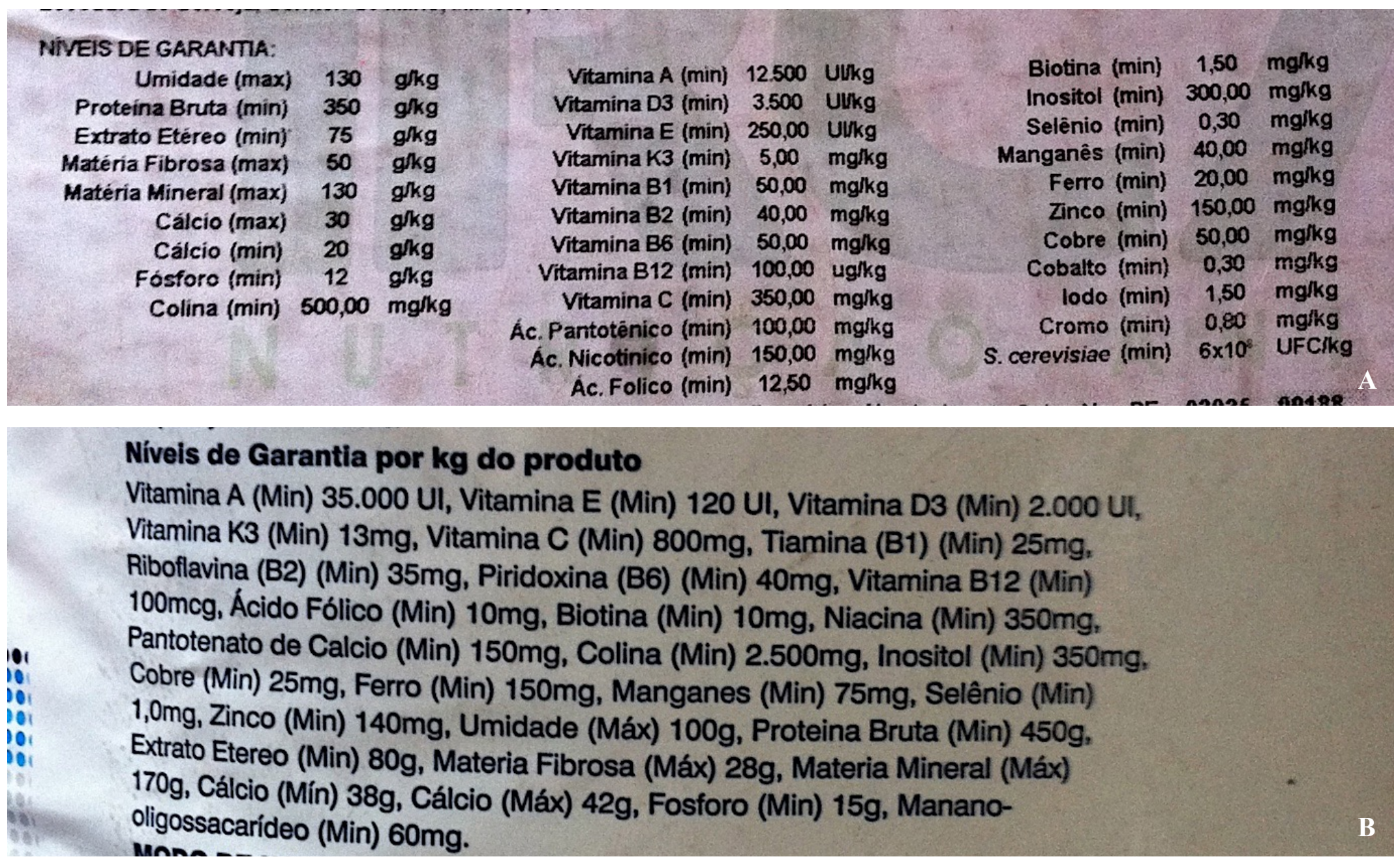

Figure 6 Shrimp (A) and tilapia (B) feed labels examples, sampled from the visited farms. 


\section{Proximate feed analysis}

Dry matter, crude protein, crude fiber, ash, and gross energy of the commercial feeds were analyzed following the AOAC methods as described by SILVA; QUEIROZ (2009) by the Bromatology and Mineral Analysis Laboratory of the Animal Science Institute in Nova Odessa, SP (APTA, SAA). Basically, dry matter was determined by drying the feed sample at $103-105{ }^{\circ} \mathrm{C}$ overnight, crude protein was analyzed by the Kjeldahl method $(\mathrm{N} \times 6.25)$, crude fiber by acid and alkaline hydrolysis, and ash by burning the feed sample in a muffle furnace at $600{ }^{\circ} \mathrm{C}$ for $6 \mathrm{~h}$. Crude fat was determined by the petroleum ether extraction with acid pre-hydrolysis only for the extruded feeds, and gross energy was determined by adiabatic bomb calorimetry.

\section{Water stability tests}

There were two rounds of test carried out, containing of the following leaching parameters: tilapia feeds - two water temperatures $\left(24^{\circ} \mathrm{C}\right.$ and $\left.30^{\circ} \mathrm{C}\right)$ and one level of salinity $(0 \mathrm{ppt})$, and one interval of immersion (5 minutes); shrimp diets - two water temperatures $\left(19^{\circ} \mathrm{C}\right.$ and $\left.32^{\circ} \mathrm{C}\right)$, two levels of salinity (5 and $\left.35 \mathrm{ppt}\right)$, and one interval of immersion (60 minute). Five replicates of each feed $(2 \mathrm{~g})$ were used in all runs. The temperatures, intervals of immersion and salinities used on the tests were based on the existing environmental conditions observed on the tilapia and shrimp farms visited during this study. The lowest and highest water temperature and salinities (in case of shrimp farm) during the year were used. The immersion times were based on the animal feeding behavior and environment.

The horizontal shaking method (Table 1) (OBALDO et al., 2002) was applied using a Lindberg/Blue $M$ refrigerated and heating circulating water bath with a shaker, Model RSWB3222A (Lindberg/BlueM, Ashville, NC, USA). The shaking speed was set to 100 cycles per minute, which represents the commercial shrimp pond and tilapia cage upon wind effect. The shaker tray held up to eight $250-\mathrm{mL}$ Erlenmeyer for each run. Stock water with the salinity levels proposed for the shrimp tests were prepared by dilution of marine water (35 ppt) collected at Instituto Oceanográfico (Ubatuba, SP, Brazil). Each flask was filled with $100 \mathrm{~mL}$ of water (distilled or saltwater depending on the treatment) and $2 \mathrm{~g}$ of feed for each leaching run. A temperature stabilization period of 5 minutes was used before add the pellets into the flasks. After incubation, all solids were recovered using a Millipore filtration apparatus with $0,7 \mu$ fiberglass filter (AP4004700, Millipore), previously dried. After 
filtration, samples were gently washed with distilled water to remove the salt. Recovered solids and original feed samples were dried in an oven at $105^{\circ} \mathrm{C}$ for $24 \mathrm{~h}$ and then cooled in a desiccator before weighing. Total dry matter loss (DML) was calculated as the ratio of dry matter recovered after leaching and dry matter of original samples expressed as percentage.

For the size and weight characteristics of the feeds, 30 pellets of each sample were weighted and measured the length, width and height, in order to calculate the. A caliper was used for the measurements. 
Table 1 - Pellet water stability method protocol for analysis of shrimp and fish feeds using the water bath apparatus.

1 Purpose and scope

1.1 Pellet water stability is important component of feed quality control.

1.2 Pellet stability measures the ability of a pellet to retain its physical integrity in the water until consumed by the animal.

1.3 The pellet stability method used for analysis employs a horizontal back and forth shaking motion to provide water movement and pellet agitation. This method is equipped with a variable shaker to simulate the required water movement and pellet agitation for different indoor and outdoor shrimp and fish cultures conditions. Water temperature and salinity are taken into account to obtain accurate and consistent pellet stability results.

2 Equipment and test apparatus

2.1 Refrigerated shaking water bath, Model RSWB3222A (Lindberg/BlueM, Asheville, NC, USA).

2.2 Erlenmeyer flask $(250 \mathrm{~mL})$

2.3 Millipore filtration apparatus with filter paper no. 3 (AP4004700, Millipore).

2.4 Oven, desiccator, aluminum moisture cans with lid.

2.5 Analytical balance with accuracy of 0.0001 .

3 Test procedure

3.1 Obtain $2 \mathrm{~g}$ of representative feed sample in duplicate for analysis.

3.2 Leach feed sample for desired immersion time using the pellet stability apparatus at 100 cpm shaker speed, desired salinity and water temperature. These test parameters may vary depending upon the actual animal culture conditions.

3.3 Use a $250 \mathrm{~mL}$ flask filled with $100 \mathrm{~mL}$ saltwater to hold the feed sample during leaching. 3.4 After the desired leaching time, rinse with distilled water to remove salt and recover all solids using a Millipore filtration apparatus with filter paper no. 3 .

3.5 Dry the recovered and original feed sample in the oven at $105^{\circ} \mathrm{C}$ for $24 \mathrm{~h}$.

$3.6 \mathrm{Cool}$ samples in a desiccator before weighing and record results for analysis.

4 Feed analysis and calculation

4.1 Perform pellet stability calculations in terms of dry matter loss using the following formula: 100 - (gram feed remaining divided by gram initial feed, multiplied by 100).

Adapted from OBALDO et al., 2002. 


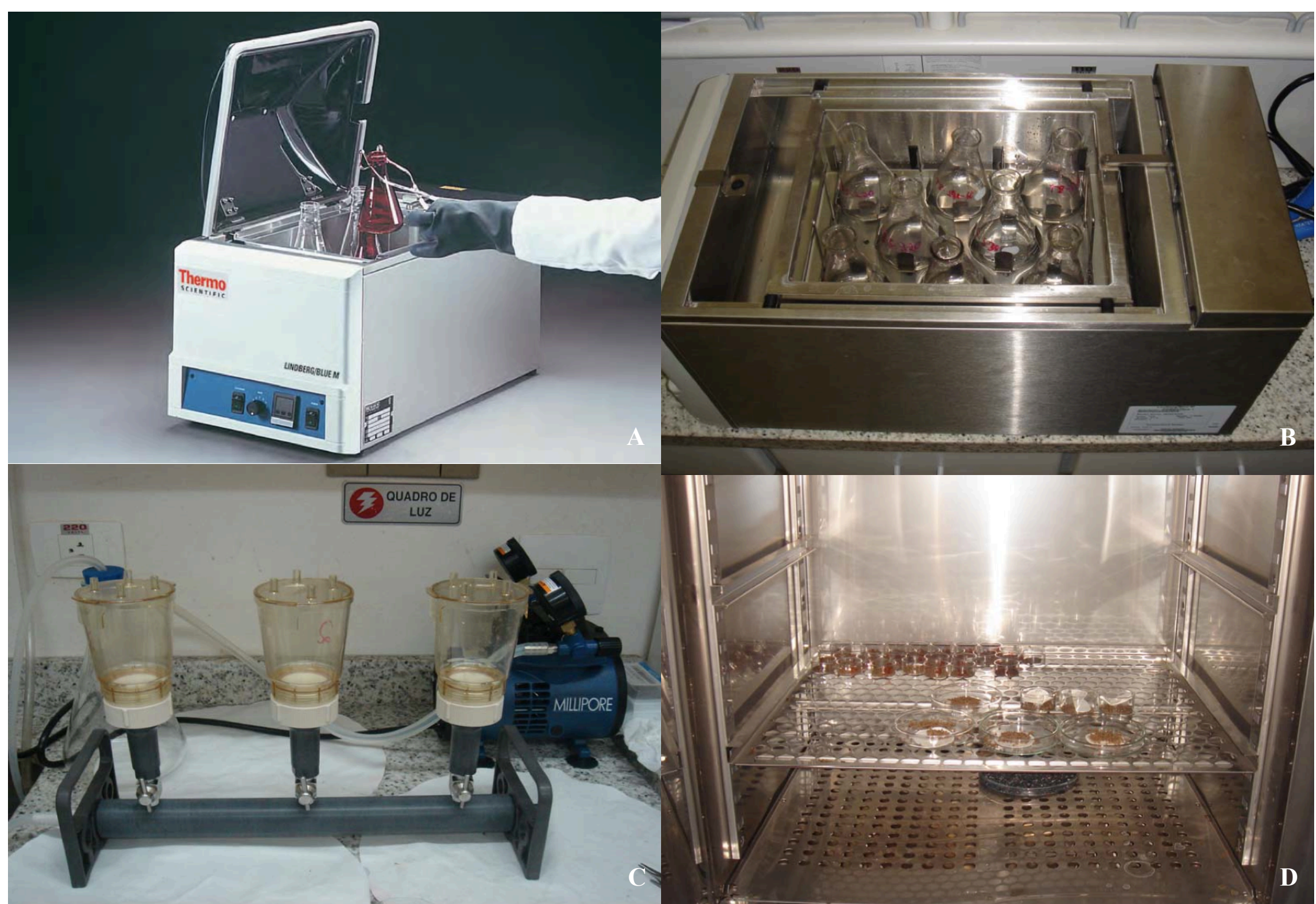

Figure 7 Equipments used for the pellet water stability applying the water bath apparatus: refrigerated shaking water bath (A), $250 \mathrm{~mL}$ flasks (B), filtration apparatus with filter $(\boldsymbol{C})$. Dry recovered and original feed samples in the oven at $105^{\circ} \mathrm{C}$ for $24 \mathrm{~h}(\boldsymbol{D})$. 
In vitro degree of protein hydrolysis $(\mathrm{DH})$

The degree of feed protein hydrolysis (DH, \%) for shrimp and tilapia were assessed using the in vitro $\mathrm{pH}$-stat system with hepatopancreas enzymes from juvenile L. vannamei and stomach and intestine enzyme extracts from cage farmed tilapia (fed individuals, 598.3 \pm $110.1 \mathrm{~g})$, respectively. The enzyme extracts were obtained from healthy animals, used on previous studies in this laboratory (LEMOS et al., 2009; YASUMARU; LEMOS, 2014). A schematic sequence of enzyme extract recovery is shown in Figure 9.

For the in vitro protein digestion, the amount of ground feed sample corresponding to $80 \mathrm{mg}$ of crude protein (CP) was placed in a $20-\mathrm{mL}$ tube with distilled water and the suspension $(10 \mathrm{~mL}$ for digestion with shrimp hepatopancreas extract; 6 and $8 \mathrm{~mL}$ for digestion with tilapia stomach and intestine extract, respectively) stirred approximately for 30 minutes to stabilize $\mathrm{pH}$ at 2.0 (stomach) with $0.1 \mathrm{~N} \mathrm{HCl}$ or 8.0 (hepatopancreas and intestine) with $0.1 \mathrm{~N} \mathrm{NaOH}$. Shrimp feed samples were submitted to hydrolysis with hepatopancreas, and tilapia feed samples with stomach and intestine extracts separately in the case of tilapia (two-stage digestion). The $\mathrm{pH}$-stat protein hydrolysis assays were tested with enzyme extract volume of 250 and $200 \mu \mathrm{L}$ from Nile tilapia stomach and intestine, and $389 \mu \mathrm{L}$ from shrimp hepatopancreas. Four replicates of $\mathrm{DH}$ analysis were run per feed, at $25 \pm 0.5^{\circ} \mathrm{C}$ for 60 minutes. The assays were carried out simultaneously in two automated titrators (Figure 8, Titrando 836, Titrando 907, Metrohm AG, Switzerland), connected to a single controlling and data logging software (Tiamo ${ }^{\mathrm{TM}}$ v. 2.2, Metrohm AG, Switzerland).

The degree of protein hydrolysis $(\mathrm{DH})$ at $\mathrm{pH} 2.0$ was calculated according to DIERMAYR and DEHNE (1990):

$\% \mathrm{DH}=[(\mathrm{V} \times \mathrm{N}) / \mathrm{E}] \times(1 / \mathrm{P}) \times \mathrm{F}_{\mathrm{pH}} \times 100$

Where:

$\mathrm{V}=$ volume of $\mathrm{HCl}$ consumed in the hydrolysis reaction $(\mathrm{mL})$,

$\mathrm{N}=$ normality of $\mathrm{HCl}$,

$\mathrm{E}=$ mass of substrate protein $(\mathrm{g})$,

$\mathrm{P}=$ number of peptide bonds cleaved $\left(\mathrm{mol} \mathrm{g} \mathrm{protein}^{-1}\right)$. For proteins which amino acid composition is not determined, $\mathrm{P}$ is generally suggested as $8.0 \mathrm{~F}_{\mathrm{pH}}=1.08$ (constant for $\mathrm{pH}$ 2.0 at $25^{\circ} \mathrm{C}$ ). 
And at $\mathrm{pH}$ 8.0, DH was calculated according to ADLER-NISSEN (1986):

$\% \mathrm{DH}=\mathrm{B} \times \mathrm{Nb} \times(1 / \alpha) \times(1 / \mathrm{MP}) \times(1 /$ Htot $) \times 100$

Where:

$\mathrm{B}=$ volume of $\mathrm{NaOH}$ consumed $(\mathrm{mL})$

$\mathrm{Nb}=$ normality of the base

$\alpha=$ average degree of dissociation of the $\alpha-\mathrm{NH}$ groups $\left(1 / \alpha=1.50\right.$ for $\mathrm{pH} 8.0$ at $\left.25^{\circ} \mathrm{C}\right)$

$\mathrm{MP}=$ mass of protein $(\mathrm{g})$

Htot $=$ total number of peptide bonds in the protein substrate [average value of 8.0 meqv $\mathrm{g}$ protein $^{-1}$ was assumed (ADLER-NISSEN, 1986)].
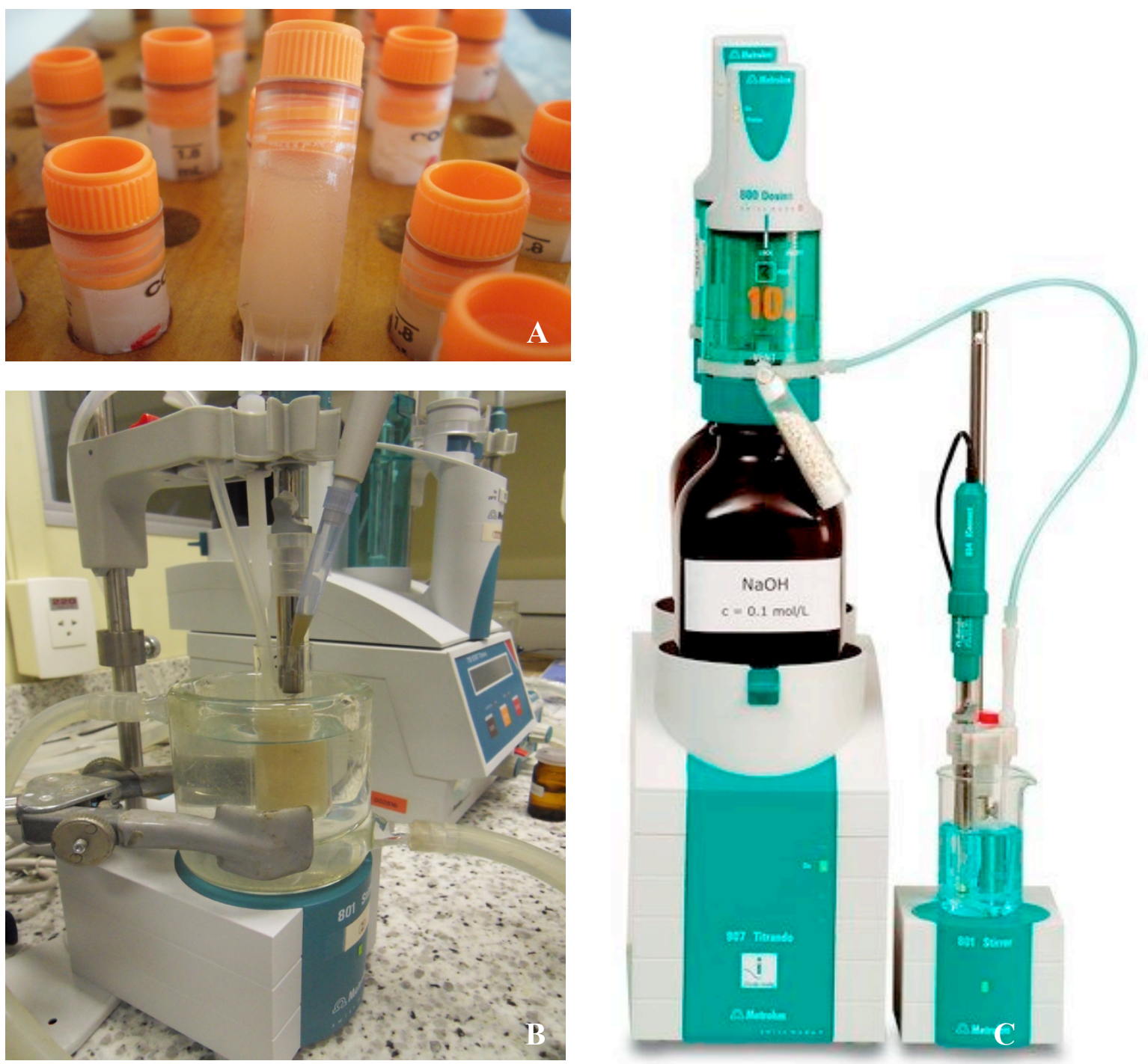

Figure 8 Ready-to-use enzymes (A). Simulation of shrimp and fish digestion in a pH-stat assay: reacting vessel kept temperature stable in glass jacket $(\boldsymbol{B})$; potentiometric titrator $(\boldsymbol{C})$. 


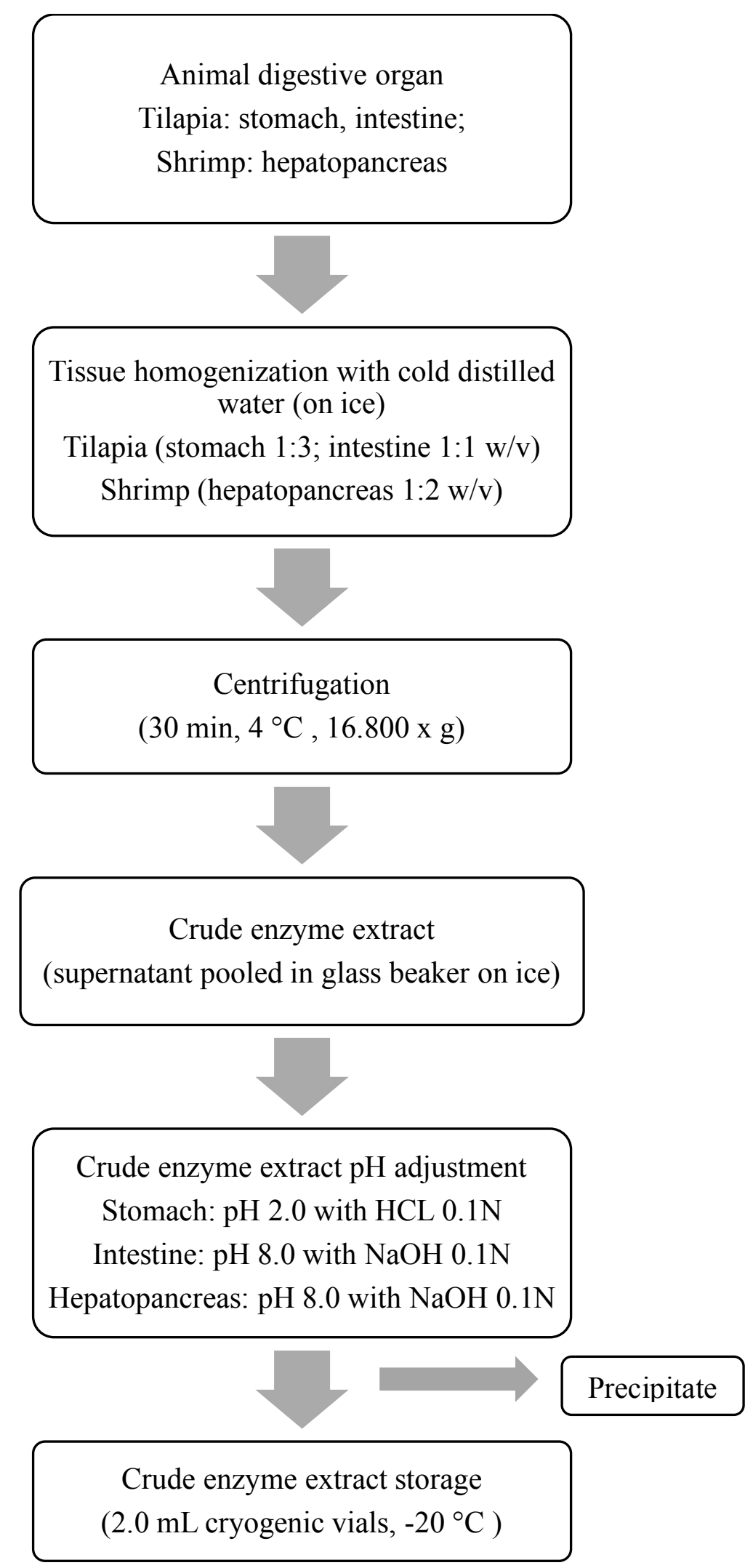

Figure 9 Flow diagram of digestive enzyme extract preparation for the determination of the in vitro degree of protein hydrolysis (DH) Nile tilapia, Oreochromis niloticus and shrimp Litopenaeus vannamei. After preparation, the hydrolytic capacity of crude enzyme extracts was standardized according to DH of specific protein substrates. Frozen stored enzyme extracts $\left(-20^{\circ} \mathrm{C}\right)$ showed to be stable for use after several months. 
NIRS survey

This study used a survey instrument consisting of ten questions regarding the use of NIRS in the feed companies, laboratories of analysis and research institutions. The survey was posted to a unique link created by the online survey host Survey Monkey (www.surveymonkey.com). All of the survey participants remained anonymous. After the survey was closed, the responses to each question were grouped and analyzed, mainly using the tools supplied by the online survey host. These tools provided full summaries of the responses to each question and also the ability to filter the survey responses using different criteria. During the time that the survey was available, a total of 10 responses were received, although not all of the participants answered every question. For questions that asked the respondents to provide further details regarding their responses in a comment, Microsoft Excel ${ }^{\circledR}$ spreadsheets were used to compile and tabulate those responses. A copy of the survey instrument is presented in the Results section (Table 12).

\section{Preliminary prediction of DH test using NIRS}

Thirty-four soybean meal (SBM) samples, obtained from a Malaysian company (Soon Soon Oilmills Sdn Bhd, Prai, Penang, Malaysia), were evaluated to predict the in vitro degree of protein hydrolysis values using NIRS. Originally the SBM samples used in the test were collected from Argentina, Brazil, India and the United States, the major soy producing countries. Moisture, lipid and ash were analyzed by the official methods and recommended practices of the American Oil Chemists' Society (AOCS, 2013), protein using the Kjeldahl method with the modifications developed by FOSS (Foss ASN 3115). The in vitro $\mathrm{pH}$-stat assays to determine degree of protein hydrolysis (DH) from the soybean meal (SBM) samples were conducted as described previously (shrimp test) on the item 2.5.

Infrared spectra of the third four SBM samples were collected from 10,000-4,000 $\mathrm{cm}^{-1}$ on a Büchi NIRFlex N500 FT-NIR spectrophotometer (Figure 10) using NIR Ware ${ }^{\circledR}$ 1.4.3010 software (Büchi, Labortechnik AG, Switzerland). Samples were scanned in triplicate with particle size of $250 \mu \mathrm{m}$. The reference DH data was then copied into NIR Ware ${ }^{\circledR}$ software to form the calibration data set. The spectra were evaluated as the mean of three scans. The NIR software, incorporating a partial least square (PLS) fit method, was then used to develop calibration models. A one-sample-out cross-validation was used for the PLS analysis. These produced regression equations based on selected parts of the spectra 
after specific mathematical treatments of the data. Cross validation tests were then run for the DH parameter using the suggested calibration models that incorporated appropriate wave number ranges and math pre-treatments.

The calibrations were evaluated by examining the statistical measurements of the standard error of cross validation (SECV) and the correlation coefficient $\left(\mathrm{R}^{2}\right)$. Generally, $\mathrm{R}^{2}$ values of 0.6 or even lower can be acceptable in a NIRS calibration, although values of over 0.8 are desirable for calibration accuracy (BERTRAND, 2001). A smaller $\mathrm{R}^{2}$ indicates predictions using PLS will not be much better than predictions using the mean value of the reference data alone. Similarly, higher $\mathrm{R}^{2}$ values indicate that NIR spectroscopy can predict quality parameters with more accuracy. WILLIAMS (2001) indicated that $\mathrm{R}^{2}=0.70-0.90$ is suitable for rough screening, $\mathrm{R}^{2}=0.90-0.97$ is suitable for screening or quality control, $\mathrm{R}^{2}=$ $0.97-0.99$ is suitable for process control, and larger values are suitable for most applications.

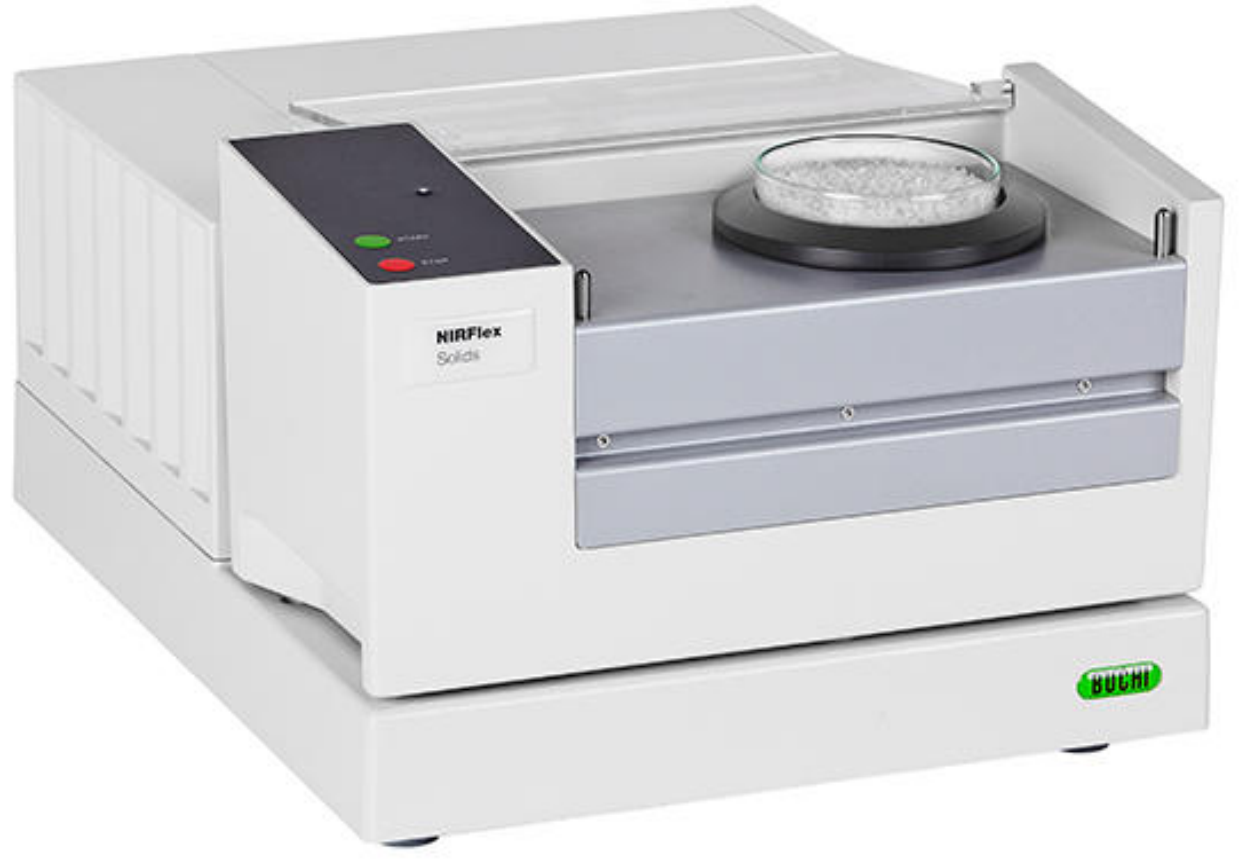

Figure 10 NIRS analyser used in the preliminary test with 34 SBM samples. 


\subsection{Results}

Declared proximate composition

The declared proximate composition for the commercial tilapia and shrimp feeds as noted from the feed bags labels during the field survey is presented in Table 2 and 3 , respectively.

Table 2 - Declared proximate composition of tilapia feeds collected in the farms (\%, "as is" basis).

\begin{tabular}{ccccc}
\hline Feed & Crude protein $(\min )$ & Crude fiber $(\max )$ & Ether extract $(\min )$ & Ash $(\mathrm{max})$ \\
\hline F01 & 32.0 & 10.0 & 5.0 & 12.0 \\
F02 & 32.0 & 9.0 & 7.0 & 12.0 \\
F03 & 32.0 & 6.0 & 6.0 & 11.0 \\
F04 & 32.0 & 6.0 & 6.0 & 11.0 \\
F05 & 32.0 & 6.0 & 6.0 & 11.0 \\
F06 & 32.0 & 6.0 & 6.0 & 11.0 \\
F07 & 32.0 & 6.0 & 6.0 & 11.0 \\
F08 & 32.0 & 7.0 & 5.0 & 10.0 \\
F09 & 32.0 & 7.0 & 6.0 & 11.0 \\
F10 & 35.0 & 6.0 & 7.0 & 12.0 \\
F11 & 32.0 & 8.0 & 4.0 & 14.0 \\
F12 & 32.0 & 8.0 & 4.0 & 14.0 \\
F13 & 32.0 & 8.0 & 4.0 & 14.0 \\
F14 & 28.0 & 8.0 & 4.0 & 14.0 \\
F15 & 36.0 & 6.5 & 8.0 & 10.0 \\
F16 & 36.0 & 6.0 & 8.0 & 10.0 \\
F17 & 32.0 & 7.0 & 6.0 & 11.0 \\
F18 & 32.0 & 5.5 & 6.0 & 13.0 \\
F19 & 32.0 & 5.5 & 6.0 & 13.0 \\
\hline
\end{tabular}

Overall, tilapia and shrimp grow-out feeds surveyed in Brazil contained 32.0\% and $35.0 \%$ of crude protein, respectively. Maximum crude fiber content range was $5.5-10 \%$ (tilapia) and 4.0-5.0\% (shrimp). Minimum ether extract range was 5.0-8.0\% for the tilapia feeds, and $6.0-10.0 \%$ for the shrimp feeds. Maximum ash declared from the feed manufacturers was $10-14 \%$ (tilapia) and $12-14 \%$ (shrimp). 
Table 3 - Declared proximate composition of shrimp feeds collected in the farms (\%, "as is" basis).

\begin{tabular}{ccccc}
\hline Feed & Crude protein $(\min )$ & Crude fiber $(\max )$ & Ether extract $(\min )$ & Ash $(\max )$ \\
\hline S01 & 30.0 & 5.0 & 7.5 & 13.0 \\
S02 & 35.0 & 5.0 & 6.5 & 13.0 \\
S03 & 35.0 & 5.0 & 6.5 & 13.0 \\
S04 & 35.0 & 5.0 & 7.5 & 13.0 \\
S05 & 35.0 & 5.0 & 6.0 & 13.0 \\
S06 & 33.0 & 5.0 & 7.5 & 13.0 \\
S07 & 32.0 & 4.0 & 8.0 & 12.0 \\
S08 & 32.0 & 4.0 & 8.0 & 12.0 \\
S09 & 38.0 & 4.0 & 6.5 & 12.0 \\
S10 & 36.0 & 5.0 & 8.0 & 13.0 \\
S11 & 35.0 & 6.0 & 7.5 & 13.0 \\
S12 & 35.0 & 5.0 & 10.0 & 14.0 \\
S13 & 35.0 & 5.0 & 10.0 & 14.0 \\
S14 & 30.0 & 8.0 & 6.0 & 13.0 \\
S15 & 35.0 & 8.0 & 6.0 & 13.0 \\
S16 & 35.0 & 5.0 & 7.5 & 13.0 \\
\hline
\end{tabular}

Proximate composition and in vitro DH of commercial feeds

The proximate composition (\%, "as is" basis) for the collected tilapia and shrimp feeds are presented in Table 4 and 5, respectively. Commercial tilapia feeds were basically extruded floating feeds, and shrimp feeds were generally pelleted sinking feeds, with a few companies also making extruded shrimp feeds. Moisture contents of the sampled feeds ranged from 4.3 to $9.5 \%$. The analyzed crude protein contents of tilapia and shrimp feeds varied between 30.9 to $39.1 \%$ and 34.3 to $43.0 \%$, respectively. The crude fiber contents of the sampled feeds were satisfactory for tilapia (3.7-7.9\%) and shrimp (2.1-4.3\%). The ether extract values of the tilapia and shrimp feeds varied between 5.6-9.7\% and $7.1-10.6 \%$, respectively. The range content of ash for the tilapia feeds was 8.4-14.7\%, and for the shrimp feeds was $8.2-15.5 \%$. Energy contents were in average 4619.9 and $4736.8 \mathrm{cal} / \mathrm{g}$ for tilapia and shrimp feeds, respectively. Overall, low variations between the samples (3\% for tilapia and $2 \%$ for shrimp) were observed. The $\mathrm{DH}$ for the tilapia feeds varied from 3.7 to $5.8 \%$ (mean $4.9 \pm 0.4 \%$ ) (Figure 11), and for the shrimp feeds, the DH varied from 3.1 to $4.4 \%$ (mean $3.75 \pm 0.44 \%$ ) (Figure 12). There was $10 \%$ and $12 \%$ of variance among the samples for shrimp and tilapia feeds, respectively. 
Table 4 - Proximate composition (\%, "as is" basis) of commercial tilapia feeds.

\begin{tabular}{cccccccc}
\hline Diet & Moisture & CP & CF & EE & NFE & Ash & Energy $(\mathrm{cal} / \mathrm{g})$ \\
\hline F01 & 6.6 & 33.8 & 4.9 & 5.6 & 35.4 & 13.7 & 4114.0 \\
F02 & 6.2 & 32.4 & 5.5 & 8.4 & 35.6 & 11.9 & 4353.0 \\
F03 & 7.8 & 32.1 & 5.2 & na & na & 9.8 & 4301.1 \\
F04 & 7.2 & 33.0 & 6.1 & 6.3 & 38.6 & 8.8 & 4364.5 \\
F05 & 7.3 & 34.2 & 5.5 & 7.2 & 35.3 & 10.4 & 4403.0 \\
F06 & 7.3 & 31.7 & 4.5 & 6.2 & 41.8 & 8.5 & 4319.1 \\
F07 & 7.7 & 31.8 & 6.4 & 5.9 & 36.5 & 11.7 & 4163.0 \\
F08 & 7.3 & 33.3 & 6.6 & 7.7 & 34.1 & 11.1 & 4272.5 \\
F09 & 5.5 & 32.9 & 7.1 & na & na & 8.1 & 4408.5 \\
F10 & 5.1 & 37.1 & 6.6 & 7.3 & 34.4 & 9.5 & 4482.1 \\
F11 & 8.6 & 28.6 & 7.2 & 7.5 & 37.3 & 10.9 & 4093.5 \\
F12 & 4.3 & 29.8 & 5.8 & 8.5 & 40.0 & 11.8 & 4251.1 \\
F13 & 6.9 & 29.2 & 5.6 & 7.5 & 40.1 & 10.6 & 4132.0 \\
F14 & 8.3 & 28.3 & 5.4 & 7.2 & 40.3 & 10.4 & 4024.5 \\
F15 & 8.1 & 34.2 & 4.7 & 9.7 & 35.4 & 8.0 & 4445.1 \\
F16 & 7.3 & 35.6 & 3.4 & 8.9 & 37.0 & 7.8 & 4514.4 \\
F17 & 7.7 & 33.3 & 6.1 & na & na & 8.9 & 4328.2 \\
F18 & 8.9 & 34.3 & 5.0 & 7.7 & 33.5 & 10.6 & 4274.0 \\
F19 & 6.9 & 35.2 & 7.0 & 7.3 & 32.0 & 11.7 & 4290.2 \\
\hline
\end{tabular}

$\mathrm{CP}$, crude protein $(\mathrm{N} \times 6.25)$; $\mathrm{CF}$, crude fiber; EE, ether extract; NFE, nitrogen-free extract calculated by difference (NFE = $100-$ moisture - CP - CF - EE - ash); na, not analyzed. Value represents mean of duplicate analysis, except for nitrogen free extract (calculated from means).

Table 5 - Proximate composition (\%, "as is" basis) of commercial shrimp feeds.

\begin{tabular}{lccccccc}
\hline Diet & Moisture & CP & CF & EE & NFE & Ash & Energy (cal/g) \\
\hline S01 & 9.3 & 34.4 & 3.9 & 8.23 & 34.7 & 9.5 & 4251.0 \\
S02 & 9.0 & 35.2 & 3.8 & 8.10 & 34.3 & 9.5 & 4264.5 \\
S03 & 8.9 & 35.6 & 3.5 & 8.37 & 34.1 & 9.5 & 4338.5 \\
S04 & 8.5 & 36.9 & 2.4 & 9.55 & 31.9 & 10.8 & 4401.0 \\
S05 & 9.5 & 36.5 & 2.9 & 9.98 & 31.3 & 9.9 & 4371.0 \\
S06 & 7.3 & 35.8 & 2.3 & 9.72 & 33.1 & 11.8 & 4387.0 \\
S07 & 7.9 & 37.3 & 2.8 & 9.58 & 31.9 & 10.6 & 4349.5 \\
S08 & 8.4 & 35.9 & 2.1 & 9.65 & 31.3 & 12.6 & 4246.0 \\
S09 & 7.9 & 39.0 & 2.0 & 7.73 & 33.6 & 9.8 & 4455.5 \\
S10 & 8.8 & 38.5 & 2.6 & 9.03 & 31.5 & 9.5 & 4399.5 \\
S11 & 8.4 & 39.4 & 3.2 & 9.91 & 27.8 & 11.3 & 4321.0 \\
S12 & 8.1 & 38.4 & 3.1 & 9.11 & 27.1 & 14.2 & 4170.0 \\
S13 & 7.8 & 36.2 & 3.1 & 10.64 & 31.7 & 10.6 & 4405.5 \\
S14 & 9.0 & 34.9 & 3.0 & 8.72 & 33.8 & 10.6 & 4395.0 \\
S15 & 7.8 & 36.9 & 3.0 & 8.08 & 34.0 & 10.3 & 4273.0 \\
S16 & 8.2 & 31.7 & 3.5 & 7.14 & 41.9 & 7.6 & 4374.5 \\
\hline
\end{tabular}

$\mathrm{CP}$, crude protein (N x 6.25); $\mathrm{CF}$, crude fiber; EE, ether extract; NFE, nitrogen-free extract calculated by difference (NFE $=100-$ moisture - CP - CF - EE - ash); na, not analyzed. Value represents mean of duplicate analysis, except for nitrogen free extract (calculated from means). 


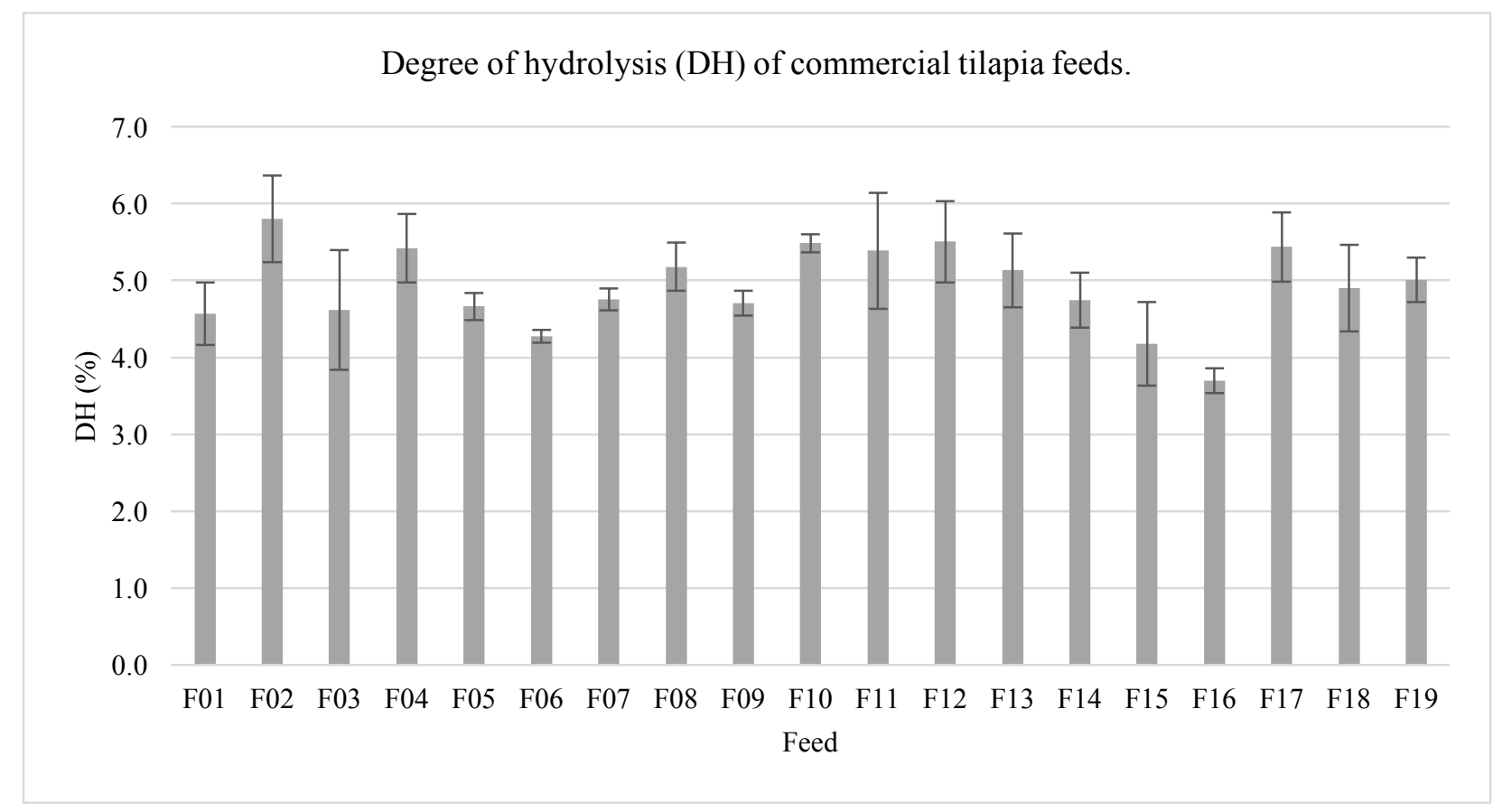

Figure $11 \mathrm{DH}(\%)$ of the nineteen commercial feeds (F01 - F19) for tilapia, Oreochromis niloticus. Each bar is the mean of four replicate test (error bar is the standard deviation). Further details in Materials and Methods.

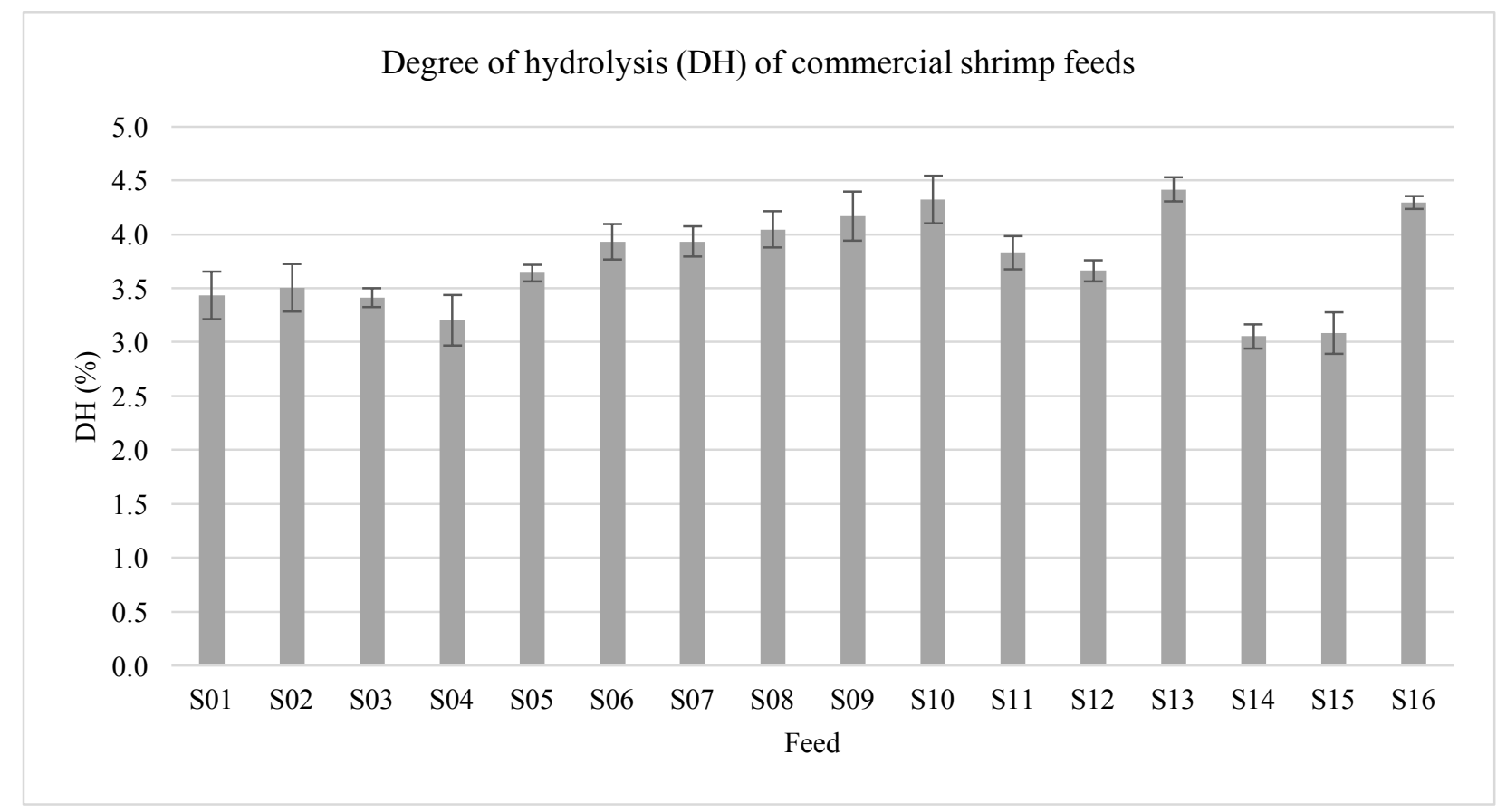

Figure $12 \mathrm{DH}(\%)$ of the sixteen commercial feeds (S01 - S16) for shrimp, Litopenaeus vannamei. Each bar is the mean of four replicate test (error bar is the standard deviation). Further details in Materials and Methods. 


\section{Differences between declared and analyzed CP and EE content}

The differences between the manufacturers stated minimum content for $\mathrm{CP}$ and EE are presented in Table 6 (tilapia) and Table 7 (shrimp). Seven tilapia feeds samples were under the manufacturers stated minimum content for $\mathrm{CP}$, and one for EE. These represents $36.8 \%$ and $5.5 \%$, respectively. Shrimp feeds were more consistent compared with tilapia feeds, with only one sample under the manufacturer stated minimum content for $\mathrm{CP}$ and two for EE. The negative differences from the manufacturer declared values are highlighted in bold.

Table 6 - Difference content (\%, "as is" basis) between the declared and analyzed crude protein $(\mathrm{CP})$ and ether extract $(\mathrm{EE})$ of the commercial tilapia feeds.

\begin{tabular}{ccccccc}
\hline \multirow{2}{*}{ Feed } & \multicolumn{2}{c}{ Manufacturer declared* } & \multicolumn{2}{c}{ Analyzed } & \multicolumn{2}{c}{ Difference } \\
\cline { 2 - 7 } & CP $(\mathrm{min})$ & $\mathrm{EE}(\mathrm{min})$ & $\mathrm{CP}$ & $\mathrm{EE}$ & $\mathrm{CP}$ & $\mathrm{EE}$ \\
\hline F01 & 32.0 & 5.0 & 33.8 & 5.6 & 1.8 & 0.6 \\
F02 & 32.0 & 7.0 & 32.4 & 8.4 & 0.4 & 1.4 \\
F03 & 32.0 & 6.0 & 32.1 & na & 0.1 & na \\
F04 & 32.0 & 6.0 & 33.0 & 6.3 & 1.0 & 0.3 \\
F05 & 32.0 & 6.0 & 34.2 & 7.2 & 2.2 & 1.2 \\
F06 & 32.0 & 6.0 & 31.7 & 6.2 & $\mathbf{- 0 . 3}$ & 0.2 \\
F07 & 32.0 & 6.0 & 31.8 & 5.9 & $\mathbf{- 0 . 2}$ & $\mathbf{- 0 . 1}$ \\
F08 & 32.0 & 5.0 & 33.3 & 7.7 & 1.3 & 2.7 \\
F09 & 32.0 & 6.0 & 32.9 & na & 0.9 & na \\
F10 & 35.0 & 7.0 & 37.1 & 7.3 & 2.1 & 0.3 \\
F11 & 32.0 & 4.0 & 28.6 & 7.5 & $\mathbf{- 3 . 4}$ & 3.5 \\
F12 & 32.0 & 4.0 & 29.8 & 8.5 & $\mathbf{- 2 . 2}$ & 4.5 \\
F13 & 32.0 & 4.0 & 29.2 & 7.5 & $\mathbf{- 2 . 8}$ & 3.5 \\
F14 & 28.0 & 4.0 & 28.3 & 7.2 & 0.3 & 3.2 \\
F15 & 36.0 & 8.0 & 34.2 & 9.7 & $\mathbf{- 1 . 8}$ & 1.7 \\
F16 & 36.0 & 8.0 & 35.6 & 8.9 & $\mathbf{- 0 . 4}$ & 0.9 \\
F17 & 32.0 & 6.0 & 33.3 & na & 1.3 & na \\
F18 & 32.0 & 6.0 & 34.3 & 7.7 & 2.3 & 1.7 \\
F19 & 32.0 & 6.0 & 35.2 & 7.3 & 3.2 & 1.3 \\
\hline
\end{tabular}

*Values obtained from the feed labels collected during the field survey (2012); na: not analyzed. 
Table 7 - Difference content (\%, "as is" basis) between the declared and analyzed crude protein $(\mathrm{CP})$ and ether extract (EE) of the commercial shrimp feeds.

\begin{tabular}{ccccccc}
\hline \multirow{2}{*}{ Feed } & \multicolumn{2}{c}{ Manufacturer declared* } & \multicolumn{2}{c}{ Analyzed } & \multicolumn{2}{c}{ Difference } \\
\cline { 2 - 7 } & CP $(\mathrm{min})$ & EE $(\mathrm{min})$ & $\mathrm{CP}$ & $\mathrm{EE}$ & $\mathrm{CP}$ & EE \\
\hline S01 & 30.0 & 7.5 & 34.4 & 8.2 & 4.4 & 0.7 \\
S02 & 35.0 & 6.5 & 35.2 & 8.1 & 0.2 & 1.6 \\
S03 & 35.0 & 6.5 & 35.6 & 8.4 & 0.6 & 1.9 \\
S04 & 35.0 & 7.5 & 36.9 & 9.6 & 1.9 & 2.1 \\
S05 & 35.0 & 6.0 & 36.5 & 10.0 & 1.5 & 4.0 \\
S06 & 33.0 & 7.5 & 35.8 & 9.7 & 2.8 & 2.2 \\
S07 & 32.0 & 8.0 & 37.3 & 9.6 & 5.3 & 1.6 \\
S08 & 32.0 & 8.0 & 35.9 & 9.7 & 3.9 & 1.7 \\
S09 & 38.0 & 6.5 & 39.0 & 7.7 & 1.0 & 1.2 \\
S10 & 36.0 & 8.0 & 38.5 & 9.0 & 2.5 & 1.0 \\
S11 & 35.0 & 7.5 & 39.4 & 9.9 & 4.4 & 2.4 \\
S12 & 35.0 & 10.0 & 38.4 & 9.1 & 3.4 & $\mathbf{- 0 . 9}$ \\
S13 & 35.0 & 10.0 & 36.2 & 10.6 & 1.2 & 0.6 \\
S14 & 30.0 & 6.0 & 34.9 & 8.7 & 4.9 & 2.7 \\
S15 & 35.0 & 6.0 & 36.9 & 8.1 & 1.9 & 2.1 \\
S16 & 35.0 & 7.5 & 31.7 & 7.1 & $\mathbf{- 3 . 3}$ & $\mathbf{- 0 . 4}$ \\
\hline
\end{tabular}

*Values obtained from the feed labels collected during the field survey (2012).

\section{Pellet water stability}

The total dry matter loss (DML) of tilapia and shrimp pellets are presented in Table 8 and 9, respectively. The DML for the tilapia feeds varied from 1.3 to $5.5 \%$ at $19^{\circ} \mathrm{C} / 0 \mathrm{ppt}$, and 2.0 to $6.4 \%$ at $32^{\circ} \mathrm{C} / 0$ ppt. On average, the DML at $32^{\circ} \mathrm{C}(3.05 \%)$ was $31.0 \%$ higher than at $19^{\circ} \mathrm{C}(4.0 \%)$. This difference is showed in Figure 13.

For the shrimp feed, the DML varied from 5.1 to $14.2 \%\left(24^{\circ} \mathrm{C} / 5 \mathrm{ppt}\right), 6.8$ to $14.5 \%$ $\left(24^{\circ} \mathrm{C} / 35 \mathrm{ppt}\right), 6.3$ to $14.5 \%\left(30^{\circ} \mathrm{C}, 5 \mathrm{ppt}\right)$, and 3.1 to $11.4 \%\left(30^{\circ} \mathrm{C} / 35 \mathrm{ppt}\right)$. The losses at $30^{\circ} \mathrm{C}$, 5ppt was $19.0 \%$ higher comparing with $24^{\circ} \mathrm{C}$ at the same salinity. At 35ppt, the DML difference between $24^{\circ} \mathrm{C}$ and $30^{\circ} \mathrm{C}$ was $10.0 \%$. Salinity also influenced the DML, with $43.0 \%$ less leaching on samples tested at $24^{\circ} \mathrm{C} / 35 \mathrm{ppt}$ comparing with $24^{\circ} \mathrm{C} / 5 \mathrm{ppt}$; and $55.0 \%$ lower at $30^{\circ} \mathrm{C} / 5 \mathrm{ppt}$ compared with $30^{\circ} \mathrm{C} / 35 \mathrm{ppt}$. The shrimp DML differences are represented in Figure 14.

Overall, extruded shrimp feeds showed to be $32 \%$ less water stable compared with the pelleted feeds, with one exception on the pelleted feed (S14). 
Table 8 - Tilapia feed processing, and dry matter loss (\%) at two different temperatures $\left(19^{\circ} \mathrm{C}\right.$ and $\left.32^{\circ} \mathrm{C}\right)$ and one salinity (0ppt) for 5 minutes.

\begin{tabular}{cccc}
\hline \multirow{2}{*}{ Tilapia feed } & Processing & \multicolumn{2}{c}{ Dry matter loss $(\%)$} \\
\cline { 3 - 4 } & extruded & $1.6(0.6)$ & $32^{\circ} \mathrm{C}$ \\
\hline F01 & extruded & $1.3(0.5)$ & $2.8(1.1)$ \\
F02 & extruded & $1.7(0.3)$ & $2.5(0.6)$ \\
F03 & extruded & $2.8(0.5)$ & $3.8(0.6)$ \\
F04 & extruded & $2.4(0.5)$ & $3.4(0.4)$ \\
F06 & extruded & $2.9(0.6)$ & $3.4(0.7)$ \\
F07 & extruded & $2.3(0.6)$ & $2.7(0.5)$ \\
F08 & extruded & $2.8(0.2)$ & $4.0(0.5)$ \\
F09 & extruded & $3.8(0.5)$ & $4.9(0.5)$ \\
F10 & extruded & $4.1(0.3)$ & $5.3(0.5)$ \\
F11 & extruded & $4.0(0.5)$ & $4.9(0.6)$ \\
F12 & extruded & $2.5(0.2)$ & $3.6(0.2)$ \\
F13 & extruded & $5.5(0.4)$ & $6.4(0.4)$ \\
F14 & extruded & $5.1(0.3)$ & $5.4(0.4)$ \\
F15 & extruded & $1.8(0.8)$ & $3.0(0.9)$ \\
F16 & extruded & $3.3(0.7)$ & $4.3(0.6)$ \\
F17 & extruded & $4.3(0.6)$ & $5.3(0.3)$ \\
F18 & extruded & $3.1(1.0)$ & $4.1(0.5)$ \\
F19 & extruded & $2.8(0.5)$ & $4.1(0.6)$ \\
\hline
\end{tabular}

Value represents mean (s.d.) of five replicates analysis. 
Tilapia feed dry matter loss (DML)

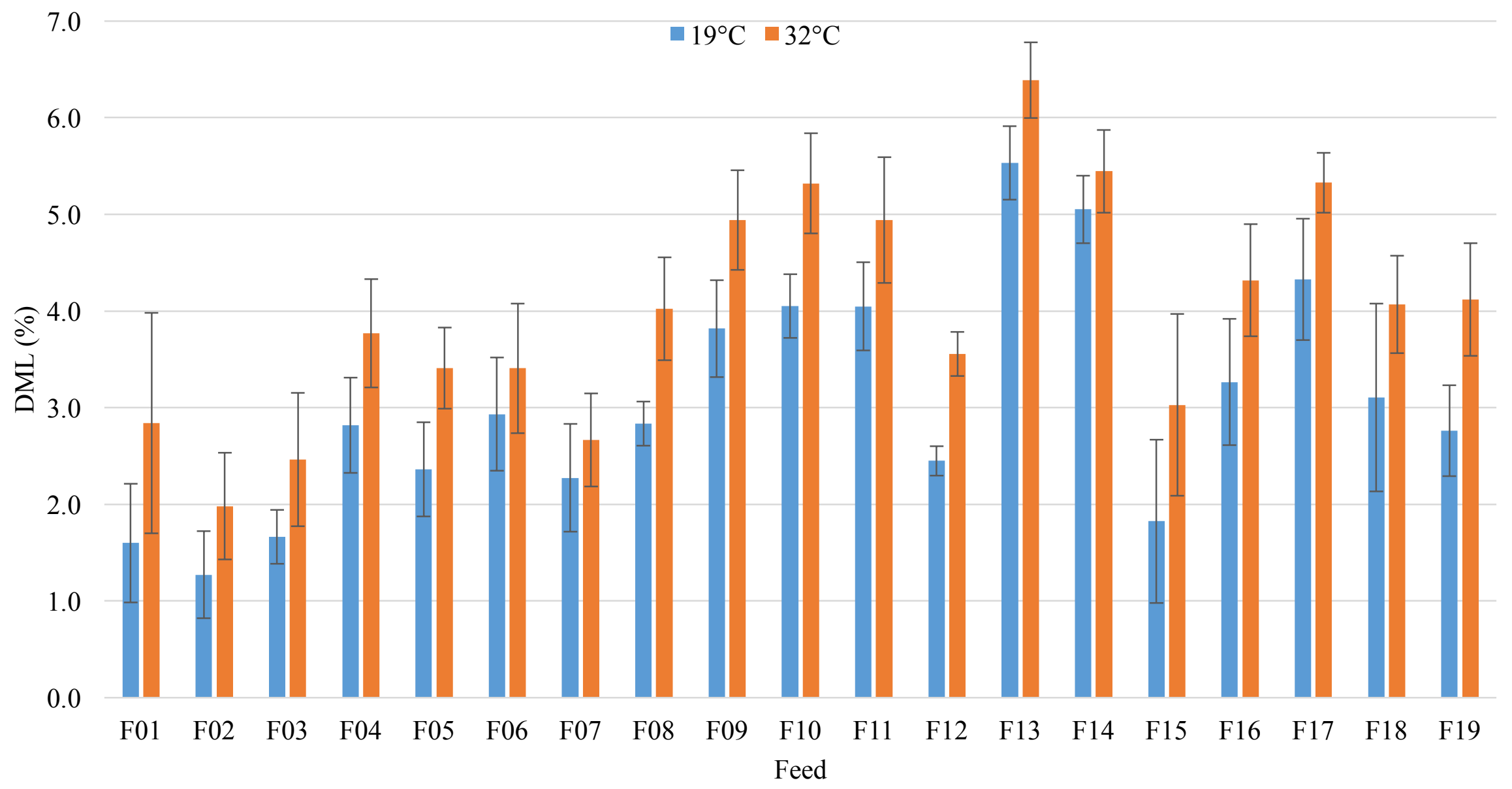

Figure 13 Dry matter loss (\%) of the nineteen commercial feeds (F01-F19) for Nile tilapia, Oreochromis niloticus. Each bar is the mean of five replicate test (error bar is the standard deviation). Each feed was tested for 5 minutes at $19^{\circ} \mathrm{C}$ and $32^{\circ} \mathrm{C}$. Further details in Materials and Methods. 
Table 9 - Shrimp feed processing, and dry matter loss evaluated at two different temperatures $\left(24^{\circ} \mathrm{C}\right.$ and $\left.30^{\circ} \mathrm{C}\right)$ and salinities (5ppt and 35ppt) for 60 minutes.

\begin{tabular}{cccccc}
\hline \multirow{2}{*}{ Shrimp feed } & Processing & \multicolumn{4}{c}{ Dry matter loss $(\%)$} \\
\cline { 3 - 6 } & & $5 \mathrm{ppt}$ & $35 \mathrm{ppt}$ & $5 \mathrm{ppt}$ & $35 \mathrm{ppt}$ \\
\cline { 3 - 6 } S01 & extruded & $9.7(0.3)$ & $7.8(0.3)$ & $10.4(0.7)$ & $8.9(0.8)$ \\
S02 & extruded & $8.2(0.4)$ & $5.8(0.6)$ & $10.4(0.3)$ & $6.1(1.6)$ \\
S03 & extruded & $8.5(1.1)$ & $5.5(0.5)$ & $11.8(1.8)$ & $6.5(0.1)$ \\
S04 & extruded & $14.2(0.4)$ & $11.0(0.5)$ & $14.5(0.2)$ & $11.4(0.4)$ \\
S05 & extruded & $9.0(0.4)$ & $5.7(1.0)$ & $10.2(0.2)$ & $6.7(0.8)$ \\
S06 & pelleted & $12.6(0.9)$ & $8.6(0.4)$ & $13.9(0.7)$ & $10.2(0.4)$ \\
S07 & pelleted & $7.3(0.9)$ & $5.4(0.9)$ & $9.1(1.4)$ & $5.2(0.5)$ \\
S08 & pelleted & $6.5(0.3)$ & $3.7(1.0)$ & $6.8(0.4)$ & $4.1(0.6)$ \\
S09 & pelleted & $7.4(0.6)$ & $4.7(0.6)$ & $8.9(1.5)$ & $5.2(1.9)$ \\
S10 & pelleted & $8.5(0.4)$ & $6.0(0.8)$ & $9.6(0.7)$ & $6.1(0.2)$ \\
S11 & pelleted & $7.5(0.5)$ & $6.2(0.6)$ & $9.1(1.1)$ & $7.3(0.7)$ \\
S12 & pelleted & $5.1(1.9)$ & $3.8(1.0)$ & $6.3(1.0)$ & $4.0(0.8)$ \\
S13 & pelleted & $5.9(0.9)$ & $3.6(1.3)$ & $7.2(0.7)$ & $4.0(0.4)$ \\
S14 & pelleted & $11.5(0.7)$ & $8.3(0.9)$ & $14.1(1.4)$ & $9.6(0.8)$ \\
S15 & pelleted & $6.5(1.1)$ & $4.4(0.2)$ & $8.7(1.4)$ & $4.4(0.1)$ \\
S16 & pelleted & $5.2(0.8)$ & $3.0(0.3)$ & $7.3(0.6)$ & $3.1(0.3)$ \\
\hline
\end{tabular}

Value represents mean (s.d.) of five replicates analysis. 
Shrimp feed dry matter loss (DML)

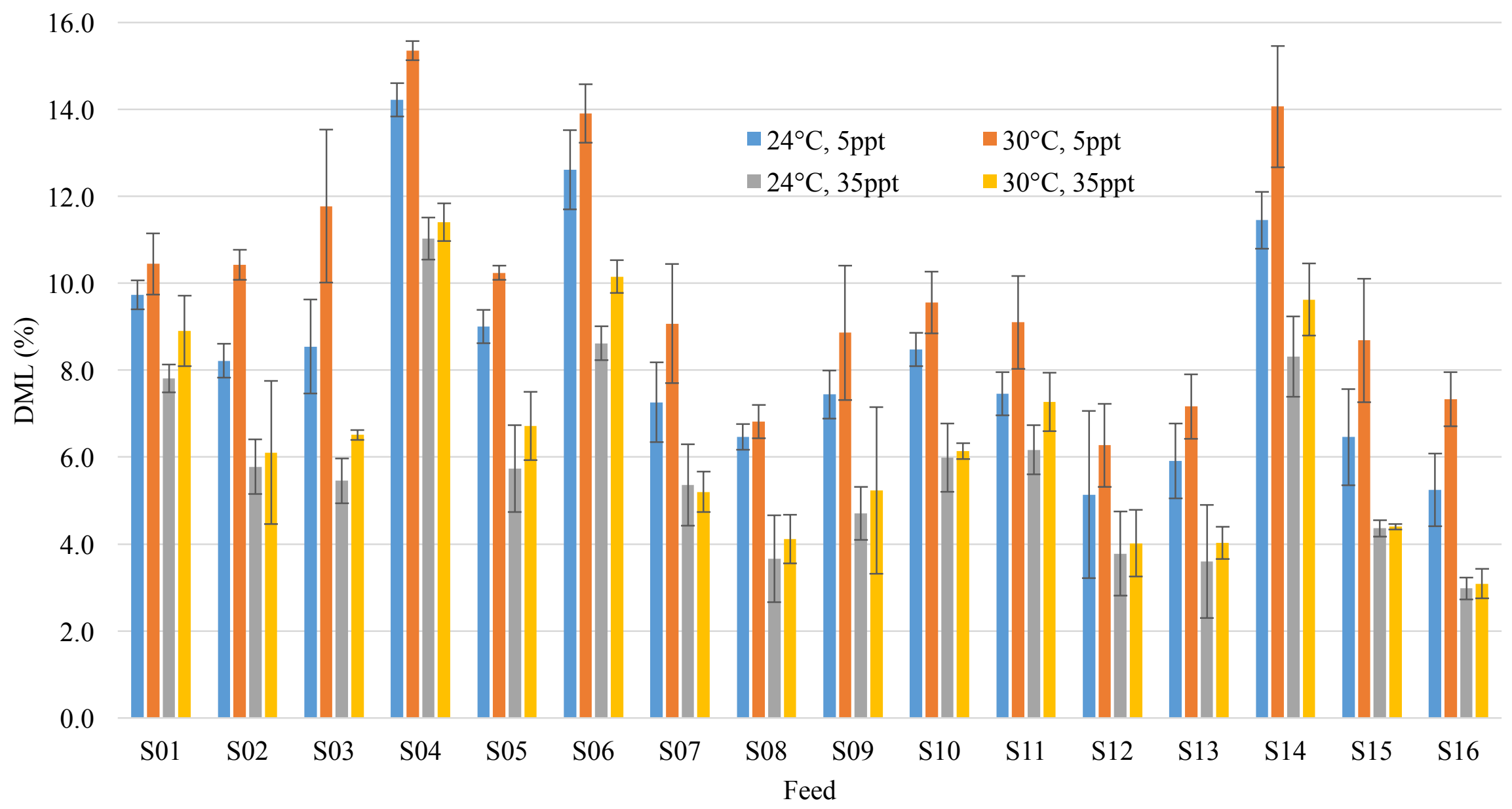

Figure 14 Dry matter loss (\%) of the sixteen commercial feeds (S01 - S16) for shrimp, Litopenaeus vannamei. Each bar is the mean of five replicate test (error bar is the standard deviation). Each feed was tested for 60 minutes at $24^{\circ} \mathrm{C}, 5 \mathrm{ppt}, 30^{\circ} \mathrm{C}, 5 \mathrm{ppt}, 24^{\circ} \mathrm{C}, 35 \mathrm{ppt}, 30^{\circ} \mathrm{C}, 35 \mathrm{ppt}$. Further details in Materials and Methods. 
Pellet size and weight

Pellets size and weight are presented in Table 10 (tilapia) and Table 11 (shrimp). Pellet diameters varied from 3.1 to $8.5 \mathrm{~mm}$ for tilapia feeds and 1.9 to $2.6 \mathrm{~mm}$ for shrimp feeds. The lengths for the tilapia feed pellets ranged from 5.2 to $7.2 \mathrm{~mm}$, and 1.5 to $7.7 \mathrm{~mm}$ for the shrimp feed pellets. The pellet weights were consistent with pellet sizes, ranging from 1.9 to $24.4 \mathrm{mg}$ (tilapia feeds) and 0.7 to $4.8 \mathrm{mg}$ (shrimp).

Table 10 - Sizes and weight analysis of pellets for the commercial tilapia Oreochromis niloticus feeds.

\begin{tabular}{cccc}
\hline Feed & Diameter $(\mathrm{mm})$ & Length $(\mathrm{mm})$ & Weight $(\mathrm{mg})$ \\
\hline F01 & $8.5(0.7)$ & $7.7(0.8)$ & $24.4(3.8)$ \\
F02 & $6.5(0.7)$ & $5.4(0.5)$ & $10.8(1.6)$ \\
F03 & $6.4(0.3)$ & $6.8(0.7)$ & $11.9(1.3)$ \\
F04 & $6.5(0.3)$ & $6.0(1.2)$ & $8.6(2.0)$ \\
F05 & $5.8(0.3)$ & $6.3(1.3)$ & $8.4(1.8)$ \\
F09 & $6.3(0.6)$ & $7.3(1.3)$ & $11.0(2.1)$ \\
F10 & $5.3(0.3)$ & $5.2(0.9)$ & $6.1(1.0)$ \\
F11 & $4.8(0.3)$ & $5.4(0.6)$ & $6.5(0.7)$ \\
F15 & $5.2(0.3)$ & $5.2(0.4)$ & $6.1(0.5)$ \\
F17 & $3.1(0.2)$ & $3.4(0.3)$ & $1.9(0.2)$ \\
F18 & $5.3(0.4)$ & $4.9(0.5)$ & $6.7(0.7)$ \\
F19 & $6.0(0.3)$ & $5.2(0.3)$ & $7.9(0.5)$ \\
F21 & $5.6(0.5)$ & $5.2(0.7)$ & $7.3(1.0)$ \\
F22 & $6.1(0.4)$ & $5.5(0.4)$ & $8.6(0.7)$ \\
F27 & $7.9(0.3)$ & $7.2(0.8)$ & $20.0(2.5)$ \\
F28 & $7.6(0.7)$ & $6.9(0.7)$ & $19.2(1.9)$ \\
F30 & $8.3(0.3)$ & $7.0(0.5)$ & $18.4(0.8)$ \\
F31 & $6.9(0.6)$ & $6.0(0.5)$ & $13.6(2.7)$ \\
F32 & $3.7(0.4)$ & $4.0(0.4)$ & $2.9(0.3)$ \\
\hline Fats &
\end{tabular}

Values represents mean (s.d.) of 30 replicates. Further details in Materials and Methods. 
Table 11 - Sizes and weight analysis of pellets for the commercial shrimp Litopenaeus vannamei feeds.

\begin{tabular}{cccc}
\hline Feed & Diameter $(\mathrm{mm})$ & Length $(\mathrm{mm})$ & Weight $(\mathrm{mg})$ \\
\hline S01 & $1.9(0.1)$ & $2.1(0.2)$ & $0.7(0.1)$ \\
S02 & $2.5(0.1)$ & $5.6(1.3)$ & $3.2(0.8)$ \\
S03 & $2.5(0.1)$ & $5.8(1.7)$ & $3.3(1.0)$ \\
S04 & $2.5(0.2)$ & $7.7(2.0)$ & $4.8(1.5)$ \\
S05 & $2.4(0.1)$ & $6.3(1.2)$ & $3.7(0.8)$ \\
S06 & $2.4(0.1)$ & $6.0(1.2)$ & $3.5(0.8)$ \\
S07 & $2.6(0.1)$ & $7.2(2.6)$ & $4.7(1.8)$ \\
S08 & $2.6(0.1)$ & $6.3(1.4)$ & $4.0(1.1)$ \\
S09 & $2.2(0.1)$ & $4.8(0.4)$ & $2.2(0.2)$ \\
S10 & $2.4(0.1)$ & $4.4(0.7)$ & $3.2(4.3)$ \\
S11 & $4.4(1.2)$ & $2.1(0.6)$ \\
S12 & $2.3(0.1)$ & $1.5(0.3)$ & $0.6(0.1)$ \\
S13 & $2.0(0.2)$ & $5.1(0.6)$ & $2.1(0.3)$ \\
S14 & $2.4(0.1)$ & $5.6(1.3)$ & $3.2(0.8)$ \\
S15 & $2.5(0.1)$ & $6.1(1.4)$ & $3.6(1.0)$ \\
S16 & $2.5(0.1)$ & $4.4(0.7)$ & $1.9(0.4)$ \\
\hline
\end{tabular}

Values represents mean (s.d.) of 30 replicates. Further details in Materials and Methods.

\section{NIRS utilization by the aquafeed industry in Brazil}

The results (questionnaire with answers) of the survey about the NIRS utilization by the aquafeed industry in Brazil, are presented in Table 12. Unfortunately, the response rate from the interviewed companies was only $13.0 \%$, which is a common survey response rate for web-based surveys. Foss was the most popular $(53.85 \%)$ equipment used by the companies, followed by Perten (15.28\%), Buchi (7.69\%) and NIRSystems (7.69\%). 53.85\% of the companies had been using NIRS for more than 5 years, and $46.15 \%$ for between 1 and 5 years. The companies mainly analyze feeds (77.92\%), ingredients (53.85\%), and raw materials $(84.62 \%)$. The measured parameters with NIRS were crude protein $(92.31 \%)$, fat (84.62\%), moisture (92.31\%), minerals (46.15\%), ash (61.54\%), and amino acids $(38.46 \%)$. The frequency of analysis was daily, every batch, more than one hundred times per month, or every change in the nutritional matrix in the equipment (mixer, pelletizer or extruder). Analysis of digestible or metabolizible nutrients of the feeds/ingredients were carried out for $38.46 \%$ of the companies. The majority $(76.92 \%)$ had their own analytical laboratory for proximate wet chemistry analysis in order to calibrate their NIRS equipment, which usually took over six months to develop (72.73\%). Standard methods of wet chemistry were used to 
determine the parameters analyzed: AOAC, AACC, Compêndio Brasileiro de Alimentação Animal, and Portaria ${ }^{\circ} 108$, de 04 de setembro de 1991, MAPA.

Table 12 - Questionnaire about NIRS utilization: Aquafeeds

\section{What brand of the equipment?}

Buchi - $7.69 \%$

Foss $-53.85 \%$

Bruker - $0 \%$

Neltec - $0 \%$

Metrohm NIRSystems - 7.69\%

Perten - $15.28 \%$

Nicolet - $0 \%$

Other (specify) $-15.38 \%$

\section{How long using NIRS?}

Less than 1 year - $0 \%$

1 to 5 years $-46.15 \%$

More than 5 years $-53.85 \%$

3. What are the products analyzed?

Feeds - $77.92 \%$

Ingredients - $53.85 \%$

Raw material $-84.62 \%$

Other (specify) - $15.38 \%$

4. What are the measured parameters?

Crude protein $-92.31 \%$

Lipid - 84.62\%

Moisture $-92.31 \%$

Minerals - 46.15\%

Ash - 61.54\%

Amino acids - 38.46\%

5. How often do the analysis? (Specify)

Daily

Daily or in each batch

Every raw material batch

More than 100 times per month

Every change of nutritional matrix, or periodically to check nutrient fluctuations

6. Do digestible or metabolizable nutrient analysis of feed and / or ingredients using NIRS?

Yes $-38.46 \%$

No $-61.54 \%$

If so, which nutrients? (Specify)

Only those mentioned above.

Raw materials such as corn, soybeans.

Amino acids and in the future PNA's - polysaccharides not amylaceous.

7. How do the chemical analysis?

Own laboratory $-76.92 \%$

Third party laboratory $-15.38 \%$

Other (specify) - 7.69\%
8. How often do the analysis?

Daily $-46.15 \%$

Weekly - 0\%

Every two weeks - $0 \%$

Monthly - 0\%

In each batch $-46.15 \%$

Other (specify) - $7.69 \%$

9. How long the calibration of the NIRS equipment have been developed?

0 to 6 months $-27.27 \%$

6 months to 1 year $-36.36 \%$

More than one year $-36.36 \%$

10. What are the standard methods used to determine the parameters analyzed?

For crude protein

AACC method 46-16 / AOCS 1987 Aa 5-91

Dumas

Kjeldahl

AOAC 2001.11

Portaria $n^{\circ} 108$, de 04 de setembro de 1991. MAPA

Compêndio Brasileiro de Alimentação Animal

For lipid

Sindirações método 52, p.120-121

Done by third party laboratory

Gravimetric

AOAC

Acid hydrolysis

Soxhlet

Portaria ${ }^{\circ} 108$, de 04 de setembro de 1991. MAPA

Compêndio Brasileiro de Alimentação Animal

For moisture

Sindirações método 56

Done by third party laboratory

Oven

AOAC

For minerals

Compêndio 2009 de alimentação animal

Portaria $n^{\circ} 108$, de 04 de setembro de 1991. MAPA

Compêndio Brasileiro de Alimentação Animal

For ash

Feito em laboratorio terceiro

Mufla

Portaria ${ }^{\circ} 108$, de 04 de setembro de 1991. MAPA

Compêndio Brasileiro de Alimentação Animal

For amino acids

HPLC

AOAC

Compêndio Brasileiro de Alimentação Animal 
The means, standard deviation (SD), coefficient of variation (CV), minimum (Min.) and maximum (Max.) values of nutrients content (determined by conventional methods, described on item 2.7) between the 34 soybean meal (SBM) samples tested on NIRS is presented in Table 13. Lipid and crude fiber content had the highest CV, with $43.8 \%$ and $41.0 \%$, respectively. The CV for crude protein was $2.9 \%$, for dry matter was $5.6 \%$, and for ash was $10.5 \%$, being the samples very consistent in these parameters. Also, the results for DH were relatively constant $(4.1 \%$ of $\mathrm{CV})$.

Table 13 - Variability in soybean meal proximate composition (\% as is) across all tested samples $(\mathrm{n}=34)$.

\begin{tabular}{llllll}
\hline & Mean & SD & CV (\%) & Min. & Max. \\
\hline Dry matter & 11.6 & 0.7 & 5.6 & 10.5 & 13.0 \\
Crude protein $(\mathrm{N} x$ 6.25) & 46.2 & 1.4 & 2.9 & 43.2 & 49.9 \\
Lipid & 1.8 & 0.8 & 43.8 & 0.5 & 3.7 \\
Ash & 6.6 & 0.7 & 10.5 & 5.9 & 8.8 \\
Crude fiber & 3.3 & 1.4 & 41.0 & 2.1 & 6.4 \\
DH & 4.1 & 0.2 & 4.1 & 3.8 & 4.5 \\
\hline
\end{tabular}

$\mathrm{CV} \%$ : coefficient of variation $=\mathrm{SD} /$ mean $\mathrm{x} 100$.

The NIR absorbance spectra of the SBM samples for the calibration with DH values between 3.77 to $4.48 \%$ are illustrated in Figure 13. The wavelength selected for the calibration set was selected from 4,000 to $9,000 \mathrm{~nm}$. 


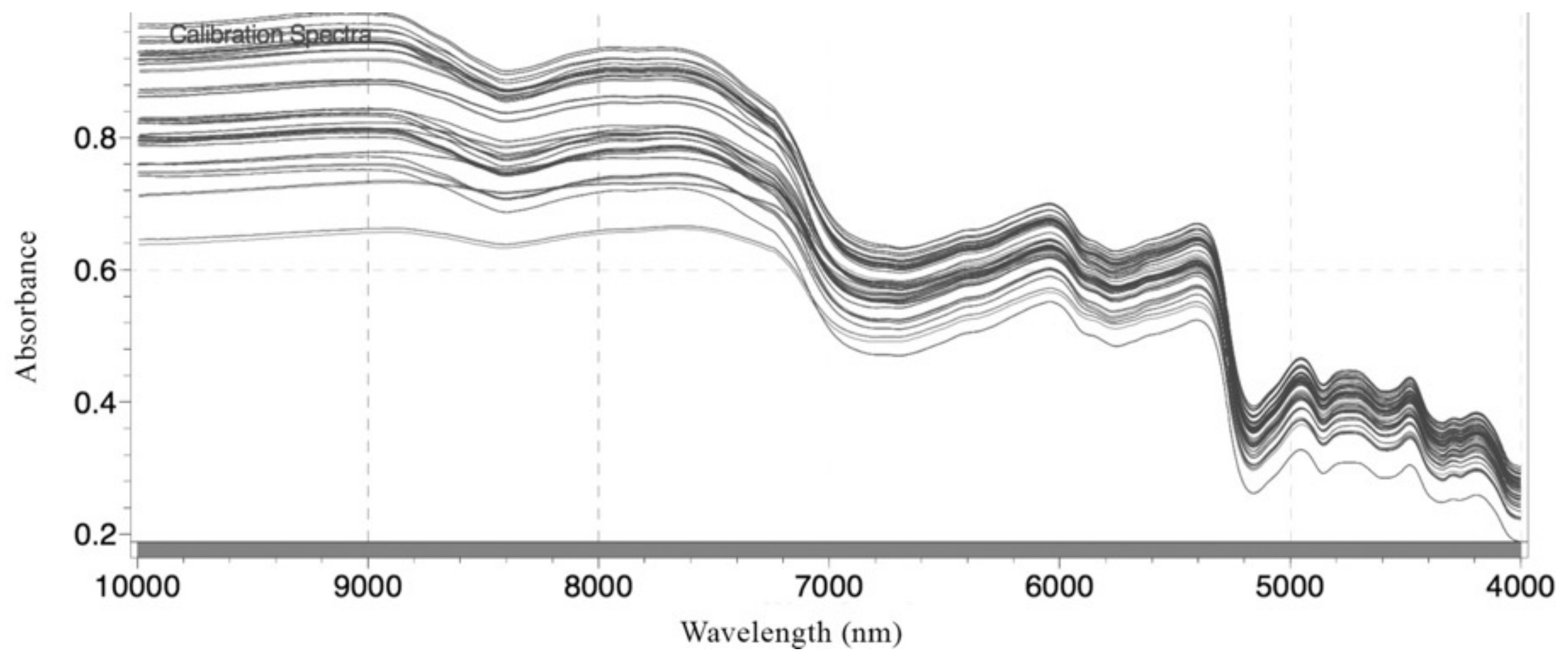

Figure 15 Original spectra data of the 34 soybean meal samples, ranging from 10,000 to 4,000 $\mathrm{nm}$. The wavelength selected for the calibration set was between 4,000 to $9,000 \mathrm{~nm}$. 
The NIR calibration values based on the DH of the 34 SBM samples are presented in Table 14. The standard deviation (SD) of the population of the validation set was 0.17 , the standard error of calibration (SEC) was 0.046 , the standard error of cross-validation (SECV) was 0.076 , the coefficient of determination $\left(\mathrm{R}^{2}\right)$ between the predicted and measured parameters was 0.92 , and the ratio performance deviation $(\mathrm{RPD}=\mathrm{SD} / \mathrm{SEC})$ was 3.63.

Table 14 - NIR calibration to estimate DH of soybean meal samples.

\begin{tabular}{lllllllll}
\hline Parameter & Model & Range of wavelength $(\mathrm{nm})$ & $\mathrm{N}$ & SD & SEC & SECV & $\mathrm{R}^{2}$ & RPD \\
\hline
\end{tabular}

$\begin{array}{lllllllll}\mathrm{DH} & \text { PLS } & 4000-9000 & 102 & 0.17 & 0.046 & 0.076 & 0.92 & 3.63\end{array}$

$\mathrm{DH}=$ degree of protein hydrolysis; PLS= partial least square; $\mathrm{N}=$ number of samples used for calibration; $\mathrm{SD}=$ standard deviation of the population of the validation set; $\mathrm{SEC}=$ standard error of calibration; $\mathrm{SECV}=$ the standard error of cross-validation; $\mathrm{R}^{2}=$ the coefficient of determination between the predicted and measured parameters; $\mathrm{RPD}=$ ratio performance deviation (SD/SEC).

The plot of NIR predicted DH against the actual values of the validation set is showed in Figure 14. The generated equation was $\mathrm{y}=0.9239 \mathrm{x}+0.315$ (where $\mathrm{x}=\%$ determined DH and $y=\%$ NIRS predicted DH) and the accuracy of the prediction was shown with a good correlation coefficient $\left(\mathrm{R}^{2}=0.92392\right)$. 


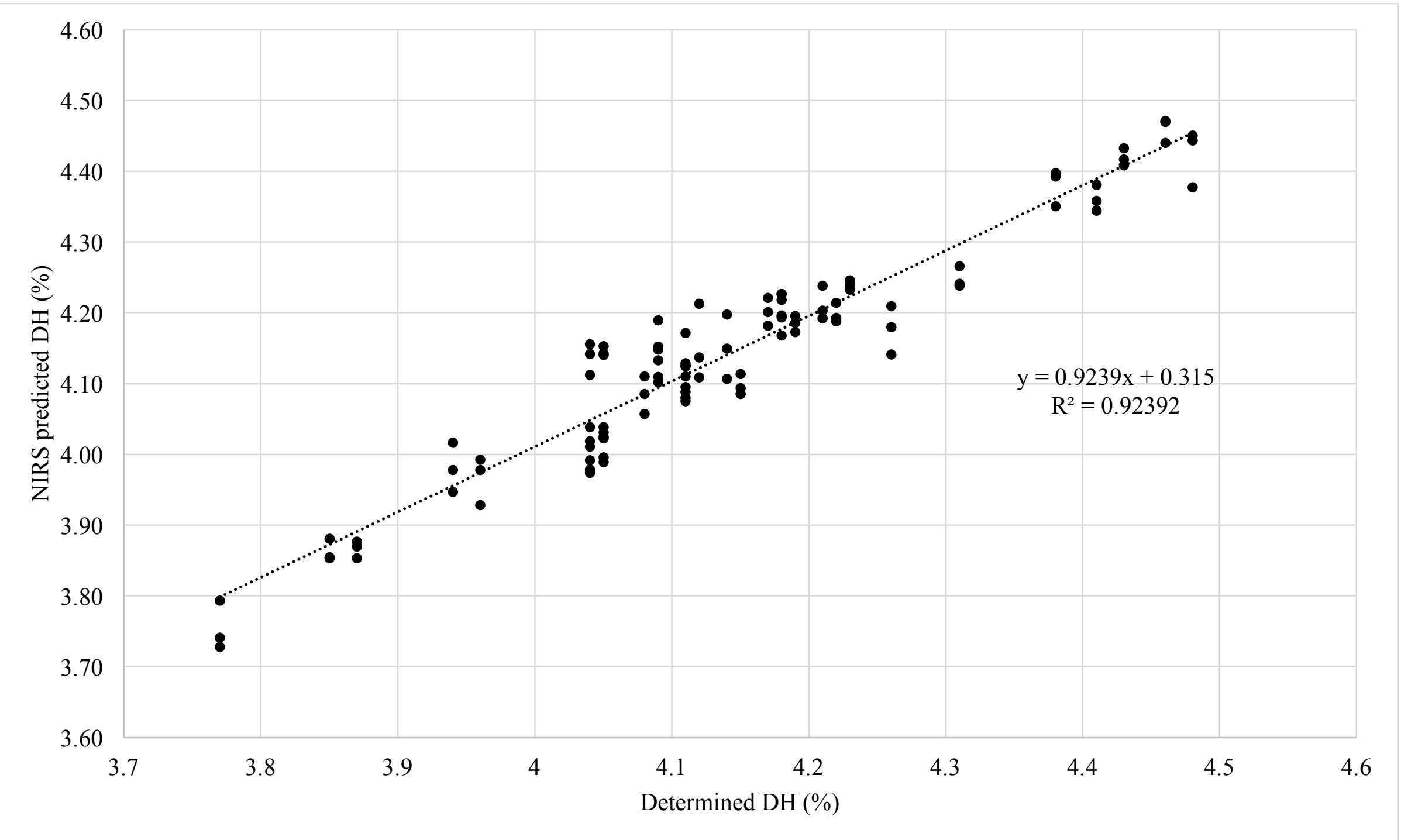

Figure 16 The plot of NIR predicted DH against the determined values of soybean meal samples $(n=102)$. 


\subsection{Discussion}

Proximate composition of commercial feed

The acceptable moisture content (less than 10\%) obtained in the sampled feeds confirmed that the feed bags were not generally exposed to humidity. The most important environmental factors influencing the storage or shelf life of a manufactured feed are ambient temperature and humidity. These factors dictate the rate at which chemical changes take place. The increase in moisture content of the stored product leads to growth of contaminating pests such as fungi, bacteria, and insects within the feed (TACON, 1988).

Protein is the major growth promoting factor in feed and its requirement of fish and shrimp are influenced by various factors such as animal size, water temperature, feeding rate, availability, quality of natural foods and overall digestible energy content of diet. Fish and shrimp feeds tend to be high in protein content at initial stages and drop as animal attain larger sizes. Grow-out and finishing tilapia feeds in Brazil ranges from 28 to $36 \%$ in protein content, and may represent up to $80 \%$ of all feeding costs at a cage farm (NUNES, 2010). Protein requirements of tilapia have been extensively studied using dose-response procedures. The results of many studies are questionable, because they: (1) were conducted indoor, (2) were short-term, (3) may not be directly applied in field trials, and (4) relied mainly on casein (which is deficient in the essential amino acid arginine) as a sole dietary protein. In this regard, semi-purified test diets containing casein, casein/gelatin mixtures or casein/amino acid mixtures as protein sources or using practical diets in which animal and/or plant ingredients served as dietary protein sources (NRC, 2011). Therefore, it is no surprise that the results of protein requirements of tilapia are varying and sometimes contradictory. Several factors including fish size or age, dietary protein source, energy content, water quality and culture conditions have been reported to affect protein requirements of tilapia. For tilapia juveniles, the protein requirement ranges from $30-40 \%$, while adult tilapia require 20-30\% dietary protein for optimum performance (EL-SAYED, 2004). In the present study, the dietary protein content (30.9-39.1\%) from the sampled feeds relies on the requirement values found in the literature for grow-out and finishing phases. The nutritional quality and cost of fish feeds largely depend on protein-rich ingredients. The great differences in the nutritional quality of certain ingredients purchased at different outlets are probably one of the contributing factors for not meeting the target protein levels in the commercial feeds. 
Because of the lack of information about the nutritive value of feedstuffs used in the field, farmers buy expensive feeds of inferior quality. In this study, $36.8 \%$ of the sampled feeds had their CP content below the labelled content. These alterations may be due to the commercial feed producers who use data from feed tables rather than from chemical analysis of their feed components as the basis of feed formulation.

The protein requirements for different shrimp species and sizes, are reported between $25-55 \%$ of the diet. Compared with other species, L. vannamei requires a lower protein diet (20-35\%) during culture than P. monodon, F. chinensis or L. stylirostris (36-42\%), and are more efficient to utilize the natural productivity of ponds, even under intensive culture conditions (WYBAN; SWEENY, 1991). Protein quality is defined by the level and availability of essential amino acids, and it has significant effect on the efficient conversion of protein in formulated feed to final product. Consequently, protein conversion is dependent on knowing the digestibility of the essential amino acids from various protein sources. Unfortunately, data on amino acid digestibility values for shrimp is limited, but there is considerable data on the apparent digestibility of various protein sources, which are a indicator of amino acid availability (TACON, 2002). The dietary nutrient requirements of shrimp under practical farming conditions, particularly in outdoor ponds, are not well understood. Aquafeeds and feeding strategies tailored to the farming system need to be developed in order to reduce feed costs and avoid unnecessary nutrient input, feed wastage, and environmental pollution. At present, few information exists about the dietary nutrient requirements of farmed shrimp in ponds; the majority of studies to date have observed shrimp growth in controlled indoor laboratory tanks with clear water (D'ABRAMO et al., 1997; FOX et al., 1995; REDDY et al., 1999; SHIAU, 1998; NRC, 2011; XIE et al., 2012; ZHOU et al., 2012). Unfortunately, in the absence of published information on the nutrient requirements of shrimp in pond-based farming systems, almost all of the commercial aquafeeds used are usually over formulated and meet a standard of providing nutritionally complete diets. The aquafeed manufacturers seem to ignore the role played by different shrimp stocking densities and natural food availability in farm systems (AKIYAMA, 1993; LAWRENCE, 1996; LAWRENCE; LEE, 1997; TACON, 1999; TRINO; SARROZA, 1995; VELASCO et al., 2000).

Only limited information is available concerning the effect of feeding high-protein feed, when it is fed at lower ration sizes to match the protein level of low-protein feed, on 
shrimp and fish performance. KURESHY; DAVIS (2002) reported significantly better weight gain for L. vannamei juveniles when fed a $32 \% \mathrm{CP}$ feed compared to $16 \%$ and $48 \% \mathrm{CP}$. A few studies have also been carried out where shrimp were fed based on their dietary energy and protein requirements. The optimal digestible energy:crude protein ratio (DE:CP) was reportedly $11.9 \mathrm{kcal} / \mathrm{g}$ protein for L. vannamei (COUSIN et al., 1991).

Several studies have shown that the variation of crude fiber levels in fish diets can change the productive performance, digestibility, gastrointestinal transit rate, digestive tract morphology, and carcass composition, especially in its lipid content (BUHLER; HALVER, 1961; LEARY; LOVELL, 1975; DUPREE; SNEED, 1966; SHIAU et al., 1988; AMIRKOLAIE et al., 2005). Although NRC (2011) recommends that plant-based feeds should contain from 3.0 to $5.0 \%$ crude fiber, there are some studies showing that many species of fish can tolerate levels up to $8.0 \%$ in feed, whereas higher concentrations may reduce the growth (LEARY; LOVELL, 1975; DIOUNDICK; STOM, 1990). Commercial shrimp diets should therefore have as low as possible crude fiber levels, not exceeding $4.0 \%$. Raw materials high in crude fiber create grinding problems and reduce the binding capacity and water stability of the shrimp pellets. The pellet water stability should last for couple hours when the feed is submerged in water using feeding trays (HERTRAMPF, 2006).

Initially, the crude fat content for the tilapia feeds (extruded) were determined by the petroleum ether extraction without an acid pre-hydrolysis, underestimating the results. Fat analysis of extruded feeds must include acid hydrolysis and not the Soxhlet method only, since its method is not capable of breaking down these complexes. However, the lipidbinding occurring during extrusion does not impair digestion by the animal when consumed (ROKEY et al., 2010). A second run of crude fat analysis including acid hydrolysis was done for all extruded samples. The lipid nutrition of farmed tilapia has been reviewed by NG and CHONG (2004). The minimum requirement of dietary lipids in tilapia diets is $5 \%$ but improved growth and protein utilization efficiency has been reported for diets with 10-15\% lipids. Lipids are an important component of shrimp feeds because they provide a concentrated energy source and supply essential fatty acids. In addition, lipids contribute to the palatability and attractability of feeds. However dietary lipids are important nutritionally, the levels and types of lipids used in shrimp feeds are also dictated by economics, constraints of manufacturing procedures, and product quality. The lipid levels of commercial shrimp feeds range $5-10 \%$ of the diet and generally rely on high-quality marine lipids to deliver 
essential fatty acids (DAVIS, 2005). In the present study, ether extract content for both, tilapia and shrimp feeds, were between the range recommended from the literature, with few samples (one of tilapia and two of shrimp) with lower content compared with the labelled.

The differences in the nutritional quality of certain ingredients purchased at different sources are probably one of the contributing factors for not meeting the target nutrient levels in formulated feeds. Because of the lack of information about the nutritive value of feeds, farmers buy feeds of inferior quality than is declared by the manufactures. A similar problem will occur for commercial feed producers who use data from feed tables rather than from chemical analysis of their feed components, as the basis of feed formulation.

In vitro degree of protein hydrolysis

The $\mathrm{pH}$-stat in vitro $\mathrm{DH}$ technique may be important to qualify or distinguish raw materials, indicating how much it could be potentially hydrolyzed in the animal digestive tract and, to a certain extent, the availability for absorption. The complex nature of food digestion in the live animal may not be easily replicated and it may also not be strictly required for consistent screening of feed protein quality, as demonstrated for terrestrial animals (MOYANO et al., 2015).

In the present study, commercial feeds of unknown composition were tested with twostage digestion for tilapia, and the results of DH were variable, ranging between 3.7 to $5.5 \%$. Few studies testing compound tilapia feeds are available in the literature. Evaluating nine grow-out commercial tilapia feeds, YASUMARU (2015) obtained DH values between 9.11$13.46 \%$, higher comparing with the actual study. This difference between both studies using commercial feeds may indicate that there was a methodological mistake during the analysis, since the feeds compositions should not have varied widely.

Also, there are few studies assessing commercial shrimp feeds available in the literature. LEMOS; NUNES (2008) testing six different commercial diets with hepatopancreas enzyme extracts (pond-raised shrimps, L. vannamei), obtained DH ranging from 3.7 to $4.7 \%$, which is very similar with results obtained for the sixteen tested commercial shrimp feeds in the present study (3.1 to $4.4 \%$ ). The verified variation in DH may be attributed to shifts in ingredient type and quality used for feed formulation. The concept of in vitro species-specific degree of protein hydrolysis can provide a suitable estimate of protein nutritional quality in commercial tilapia and shrimp feeds. Applying the LEMOS et al. (2009) apparent protein digestibility (APD) model (non-linear Rational Function model: APD versus DH) with experimental shrimp diets, variation in prediction of 
APD for the shrimp diets ranged from 81.7 to $91.6 \%$, which can be considered high because of the use of purified diets on that study.

The DH has emerged with potential as accessory method in quality control of raw materials in the aquafeed manufacturing industry (DE MUYLDER et al., 2008; LEMOS; TACON, 2011). For feed manufacturers, the DH could assist classification of protein from different ingredients or a certain ingredient from different suppliers, as an additional criterion for the quality control of aquafeeds.

\section{Pellet water stability}

Many finfish such as tilapia are fast feeders and will swallow any suitable size pellet once they have learned to feed on prepared diets. For tilapia, the pellet need to be stable in water for only a few minutes. In this study, the tilapia pellet immersion of 5 minutes (freshwater) was enough for the feed loose 1.3 to $6.4 \%$ of dry matter, being this loss increased at higher temperature. Also, the fact that all the tilapia feed samples were extruded, may have contributed to their water stability. Extrusion is characterized by higher levels of moisture, heat, and pressure than pelleting. Usually, the mixture of finely ground ingredients is conditioned with steam or water and may be precooked before entering the extruder. The effects of processing can differ for different species, and it is important to apply the appropriate processing technique to maximize production efficiency at the lowest possible cost. Sometimes, the additional cost of some processing can be unwarranted (TACON, 1990). Many ingredients absorb water, which leads to pellets becoming unstable in water. For instance, wheat and rice bran severely reduce the water stability while cereal by-products act as binders (particularly when gelatinization occurs). Most oilseed by-products, like soybean, meal allow for good water stability and animal by-products (fishmeal, poultry by-product meal, etc.) are relatively poor binders (FAO, 2016). The adhesiveness of soy protein is caused by intermolecular forces (electrostatic and covalent disulphide bonding) in unfolded proteins (KUMAR et al., 2002).

On the other hand, the loss of dry matter and water-soluble nutrients from shrimp feeds through leaching is a serious technological problem found by nutritionists and feed producers due to the slow feeding habits of crustaceans, compared with fish (TACON, 1996). The loss of nutrient and the rate at such loss occurs (in variables temperatures and salinities) were not evaluated in this study and therefore recommended for further investigations. For 
example, GADIENT; SCHAI (1994) reported the loss of selected vitamins from a shrimp pellet after a $2-\mathrm{h}$ immersion period as thiamine $40 \%$, vitamin C $53 \%$, riboflavin $28 \%$, vitamin E $0 \%$, and vitamin A $0 \%$. These losses also may be attributed to other causes, such as extrusion machinery, drying conditions or the vitamin forms used. Natural binders such as wheat gluten, high gluten wheat flour and other starch-rich ingredients are the most commonly used binders in shrimp feed. Some synthetic binders have also been used successfully. Also, good feeding practices, like increased feeding frequency reduce the exposure time of pellets in the water, thus decreasing the adverse effects of leaching of watersoluble nutrients.

In the present study, the DML of shrimp diets was influenced by the feed processing, temperature and salinity of the leaching medium. With expected higher physical stability of the extruded feeds, the DML of the commercial extruded feeds showed to be $32 \%$ higher compared with the pelleted feeds. This may be due to the fact that extrusion results in a feed with a sponge-like structure which can take up relatively large amounts of moisture when immersed in water, leading to a higher leaching of water-soluble nutrients (GADIENT: SCHAI, 1994). Also, it was noticed a higher turbidity in the water derived from the leached extruded feeds, compared with the pelleted. Furthermore, the results indicate that higher water temperatures and lower levels of salinity increased the DML. This observation can be attributed to the lower ionic concentration in $5 \mathrm{ppt}$ water than in $35 \mathrm{ppt}$, causing fast nutrient dissolution of the pellets, which was then aggravated by the higher water temperature. This result is similar to the observations reported by OBALDO et al. (2002), using commercial and pelleted feeds.

The size range of the pellets were consistent with the manufacturers labels and are generally used for grow-out and finisher feeds. Beyond the influence of temperature and salinity in the DML of feeds, pellet and particle size also effect its stability. Variable pellet sizes result in feed wastage and show poor quality control on the part of the feed manufacturer. Variable size can result from transport and handling damage due to poor pellet integrity. Such feeds have low water stability and high amount of fines. OBALDO; TACON (2001) testing shrimp diets, found that the water stability decreased from $82.5 \%$ to $76.3 \%$ as the $3.0 \mathrm{~mm}$ pellets were reduced to $0.7 \mathrm{~mm}$ crumbles, although preference would be given to larger pellets due to higher growth performance and better pellet water stability obtained on this study. The optimum size of pellets varies depending on the size of animals. 
Even with a low feedback from the surveyed companies (13\%) it was observed that NIRS has gained almost routine use in many feed manufacturers for the evaluation of nutritional analysis of feed ingredients and compounded feeds. Mainly incoming raw materials are analyzed to verify quality, to ensure proper ration supplementation, control diet formulation, and optimize least-cost formulation. Moreover, NIRS analysis is used to confirm that the finished feed matches the required specifications and to generate data for documentation. The interviewed companies are using NIRS mainly to measure moisture, crude protein, lipid, minerals, ash, and amino acids contents. These analyzes are done daily or in every different batch of incoming raw materials. To ascertain with accuracy and speed the actual nutrient profile of individual raw materials and the final compounded nutrient status, the use of NIRS have helped considerably, particularly at the commercial production level where the scale of operation is sufficient to justify the costs (BERTRAND, 2001).

NIRS can be used in many applications throughout the aquafeed industry and besides all the possible applications previous mentioned, it can also be used to predict total digestible nutrients, digestible energy, metabolizable energy, and net energy of maintenance. Calcium and phosphorous levels can also be estimated. The technology can additionally be used to screen ingredients for anti-nutritional factors and other toxic or harmful substances that might cause poor growth or mortality in fish and shrimp. In addition to the investment involved in the acquisition of NIRS equipment, there are also costs to develop the calibration curves. It must be calibrated with samples of known concentrations, which is time-consuming, laborious and costly. Separate spectra for each ingredient and feed group must be developed.

Only one surveyed company seems to be using NIRS for amino acids analysis. Like other analysis, the essential amino acid profile of each ingredient can be analyzed by NIRS through the development of robust calibrations. Software is available to predict the total and digestible amino acid profiles of different conventional feed ingredients for different species. Named AminoNIR ${ }^{\circledR}$ spectroscopy, it is offered by one of the popular feed additive companies to their customers as a complementary service to promote their products.

In addition to all of these advantages of using NIRS in the feed manufacturing process, it also can be applied in the field. The largest shrimp farm in Brazil (Potiporã Aquacultura, RN) is using NIRS to evaluate the feeds acquired from third parties, and all 
feeds that enters the farm is analyzed before truck unloading and storage. If the product does not meet their established quality standards, feed is rejected, and the supplier is informed (NUNES et al., 2015).

\section{Preliminary test with SBM samples}

Although this preliminary study suggests the potential of NIRS to analyze digestible parameters for soybean meal samples, the applications of NIRS in aquaculture is still in early stages. There have been few studies reported in the literature on the development of calibrations for digestible value parameters of raw materials for aquaculture feeds. As with other studies recently published in aquaculture, much of the monogastric NIRS calibration work has focussed on the assessment of discrete component raw materials (VAN BARNEVELD et al., 1998; PUJOL et al., 2007; GLENCROSS et al., 2015). GLENCROSS et al., 2007 evaluated the potential of NIRS to predict digestible protein and energy values of 120 different samples of lupin meal with rainbow trout (Oncorhynchus mykiss), comparing with previous in vivo digestibility experiments done over five years. They observed that the digestible nutrient and energy content of the lupin meals reflected the combined effects of both ingredient digestibility and ingredient composition (specially protein and lignin content), resulting in high variability (close to $60 \%$ ) on the digestible protein values. In the present study, the consistent compositions between the SBM samples, may have resulted in the accurate prediction of DH using NIRS. The composition values agree with those usually found in SBM used by the feed industry.

The performance of the calibration model Partial Least Square (PLS) was evaluated using the standard error of calibration (SEC), the coefficient of determination between the predicted and measured parameters $\left(\mathrm{R}^{2}\right)$, and the standard error of cross-validation (SECV). The SECV is the single best estimate of the prediction capability of the equation (SHENK; WESTERHAUS, 1996). The NIR equation was selected based on the higher $\mathrm{R}^{2}$ value $(0.92)$ and lower SECV (0.076), since those parameters are routinely used to evaluate the efficiency of NIR equations. To be acceptable, the NIR equations must have an $\mathrm{R}^{2}$ higher than 0.8 , and a SECV close to the SEC (WILLIAMS, 2001). The SECV value on this preliminary test was 0.076 , close to 0.046 of the SEC. R square values of 0.6 or even lower can be acceptable in a NIRS calibration, although values of over 0.8 are desirable for calibration accuracy (BERTRAND, 2001). As such, the ratio performance deviation (SD/SEC) value obtained 
from the present study are at or close to those values considered indicated of robust calibrations for DH. 


\subsection{Conclusions}

Feed is the most important input in increasing aquaculture production and profits. Success or failure of the activity depends, to a large extent, on the quality of the diet. Feed quality, usually alleged as the responsibility of the feed manufacturer, is also affected by factors outside of the feed company such as handling, storage, and use. Quality differences between production batches are common, and these are due mainly to differences in ingredients used, batch of raw materials, processing settings, and storage conditions. Since a new feed batch is used in the farm every few days or weeks, monitoring chemical quality for every batch becomes costly. For economic and practical reasons, an average farmer cannot depend on chemical tests to routinely monitor feed quality. However, these tests are a duty of the feed companies. Poor regulatory control and a lack of standards along the aquafeed value chain are limitations to feed and feed ingredient quality. Farmers must be assured of the quality of the feeds that they are purchasing.

The development and use of compound aquafeeds has been a major factor in the global expansion of fish and shrimp farming, and efficient feed management is critical to maintain and improve the financial and environmental viability of the industry. On the other hand, feeds must be aligned to account for the availability of natural food in ponds in order to spare critical and expensive nutrients, such as proteins, vitamins and minerals. Develop appropriate feed formulations that take into consideration the role of natural productivity is critical. Also, there is an urgent need for formulating suitable feeds, which incorporate lowcost locally available ingredients.

Good water stability of feeds reduces waste from physical disintegration, leaching of attractants and water soluble ingredients, and pollution of the environment. Pellet water stability is an important quality parameter in the manufacture of aquafeed. High water stability may be achieved by proper feed formulation, suitable selection of ingredients with desirable functional properties, and good feed manufacturing processes. With improvements in the efficiency of aquaculture production systems and the definition of the nutritional requirements for these species there will be an increased need to improve our capacity to manage the nutritional quality of aquaculture feed ingredients.

The in vitro $\mathrm{pH}$-stat species-specific method to determine the degree of protein hydrolysis $(\mathrm{DH})$ showed to be a useful tool to evaluate the commercial ingredients and feed 
quality. Assay conditions (temperature, medium salinity, incubation time, and enzyme:substrate ratios) according to the animal physiological status should be taken into account for the consistency of the in vitro determination. Routine use of the method may also be dependent on the ready availability of more ready-to-use sources of enzyme extracts.

The further development of rapid, accurate and cost-effective analysis of raw materials using NIRS remains one of the most promising options to address this issue. The NIR technology is now ready to be implemented in practical aquafeed formulation. The industry should adopt this technology responsibly and promote the interested feed ingredient suppliers and other researchers to develop more applied research. NIRS can make the link between advanced scientific knowledge generated by scientists in laboratories and application in the field. It has most of the properties of an efficient tool for quality control at different levels in the feed production process, including raw materials obtaining, intermediate products, and finished feeds. 


\subsection{References}

AARSETH, K. A.; SORENSEN, M.; STOREBAKKEN, T. Effects of red yeast inclusions in diets for salmonids and extrusion temperature on pellet tensile strength: Weibull analysis. Journal of Animal Feed Science and Technology, v. 126, p. 75-91. 2006

ABCC (Associação Brasileira dos Criadores de Camarão). Historico da carcinicultura no Brasil. Available at: http://www.abccam.com.br. 2004

AOCS 2013. Official methods and recommended practices (6th ed.). Urbana, IL: Association of Oil Chemists Society. 2013.

ADLER-NISSEN, J. Enzymic hydrolysis of food proteins. Elsevier, New York, NY. 427 pp. 1986.

AGUILAR, F. D. M.; OVERA-NOVOA, M.; ROSAS, C. In vitro digestibility: standardizing methods using gastric juice of Octopus maya in the way of improve foods for octopus culture. Book of Abstracts, Cephalopod International Advisory Council Symposium 2012, 27 Oct-02 Nov, 2012, Florianópolis, Santa Catarina, Brazil, 129. 2012.

AGUIRRE-GUZMAN, G.; RICQUE-MARIE, D.; CRUZ-SUAREZ, L. E. Survival of agglomerated Saccharomyces cerevisiae in pelleted shrimp feeds. Aquaculture, v. 208, p.125-135. 2002.

AKYIAMA D.; POLANCO B. Semi-Intensive Shimp Farm Management - Tecnical Manual (ed. by B. Polanco), p. 30 American Soybean Association, Caracas,Venezuela. 1997.

AMIRKOLAIE, A. K. Reduction in the environmental impact of waste discharged by fish farms through feed and feeding. Reviews in Aquaculture, v. 3, p. 19-26. 2011.

AMMAR, A. A. Effect of extruded and trash fish diets on growth performance and pond productivity of sea bream (Sparus aurata), the sea bass (Dicentrarchus labrax) and the flat head grey mullet (Mugil cephalus) reared in polyculture system in earthen ponds. Egyptian Journal of Aquatic Research, v. 12, n. 1, p. 43-58. 2008.

BALIAO, D. D.; DOSADO, N. S. Tilapia cage farming in freshwater reservoir using artificial diets during dry and wet seasons. Philippine Agricultural Scientist, v. 94, 3845. 2011.

BERTRAND, D. Near infrared spectroscopy and it applications for feed quality control. In A.F.B. van der Poel, J.L. Vahl \& R.P. Kwakkel, eds. Advances in nutritional technology. Proceed- ings of the First World Feed Conference, pp. 11-45. Wageningen, the Netherlands, Wageningen Academic Publishers. 2001.

BORGHETTI, N. B.; OSTRENSKY, A.; BORGHETTI, J. R. Aqüicultura: uma visão geral sobre a produção de organismos aquáticos cultivados no Brasil e no mundo. Curitiba: Grupo Integrado de Aqüicultura e Estudos Ambientais, v. 1, p. 128. 2003

BUHLER, D. R.; HALVER, J. E. Nutrition of salmonid fishes. IX. Carboidrate requeriments 
of Chinook salmon. Journal of Nutrition, v. 74, p. 305-318. 1961.

CEN, H. Y; HE, Y. Theory and application of near infraed reflectance spectroscopy in determination of food quality. Trends in Food Science and Technology, v.18, n.2, p. 72-83. 2007

CHAKRABORTY, S. B.; MAZUMDAR, D.; BANERJEE, S. Determination of ideal stocking density for cage culture of monosex Nile tilapia (Oreochromis niloticus) in India. Proceedings of The Zoological Society of London, v. 63, p. 53-59. 2010.

COUSIN, M., CUZON, G.; BLANCHET; E.; RUELLE, F. Protein requirements following an optimal dietary energy to protein ratio for Penaeus vannamei juveniles. In: Kaushik, S.J., Liquet, P. (Eds.), Fish Nutrition in Practice. Institut National de la Recherche Agronomique, Paris, France, pp. 599-606. 1991.

COUSIN, M.; CUZON, G.; GUILLAUME, J.; AQUACOP. Digestibility of starch in Penaeus vannamei: in vivo and in vitro study on eight samples of various origin. Aquaculture, v. 140, p. 361-372. 1996.

D'ABRAMO, L.; CONKLIN, D. E.; AKIYAMA, D. M. Crustacean Nutrition. Advances in World Aquaculture Vol. 6. World Aquaculture Society Publication, Baton Rouge, USA. 1997

DAVIS, D. A. Nutrient Requirements of Penaeid Shrimp. Global Aquaculture Advocate, v. 8, n. 4, p. 72-74. 2005

DE MUYLDER, E.; LEMOS, D.; VAN DEN VELDEN, G. Protein hydrolysis of PAP shows the nutritive value for shrimp feeds. Aquaculture Asia Pacific 4, Sep/Oct, 18-19. 2008.

DIERMAYR, P.; DEHNE, L. Controlled enzymatic hydrolysis of proteins at low $\mathrm{pH}$ values: 1. Experiments with BSA. Zeitschrift für Lebensmittel-Untersuchung und Forschung, v. 190, p. 516-520. 1990.

DIMES, L. E.; HAARD, N. F. Estimation of protein digestibility - I. Development of an in vitro method for estimating protein digestibility in salmonids (Salmo gairdneri). Comparative Biochemistry and Physiology, v. 108A, p. 349-362. 1994.

DIMES, L. E.; HAARD, N. F.; DONG, F. M.; RASCO, B. A.; FORSTER, I. P.; FAIRGRIEVE, W. T.; ARNDT, R.; HARDY, R.W.; BARROWS, F. T.; HIGGS, D. A. Estimation of protein digestibility - II. In vitro assay of protein in salmonid feeds. Comparative Biochemistry and Physiology, v. 108A, p. 363-370. 1994.

DIOUNDICK, O. B.; STOM, D. Effects of dietary á-cellulose on the juvenile tilapia, Oreochromis mossambicus (Peters). Aquaculture, v. 91, n. 3/4, p. 311-315. 1990.

DUPREE, H. K.; SNEED, K.E. Response of channel catfish fingerlings to different levels of major nutrients in purified diets. Bureau of Sport Fisheries and Wildlife. U. Technical Paper n. 9. 1966. 
DYER, D. J.; FENG, P. NIR destined to be major analytical influence. Feedstuffs, Nov 10, 16-19, p. 24-25. 1997.

EL-SAYED, A. M. Protein nutrition of farmed Tilapia: searching for unconventional sources. Pages 364-378 in R. Bolivar, G. Mair, K. Fitzsimmons, editors. New dimensions in farmed tilapia: proceedings of the Sixth International Symposium on Tilapia Aquaculture 2004, Manila, Philippines. World Aquaculture Society, Baton Rouge, Louisiana, USA. 2004

EZQUERRA, J. M.; GARCÍA-CARREÑO, F. L.; CARRILLO, O. In vitro digestibility of protein sources for white shrimp Penaeus vannamei. Aquaculture v. 163, p. 123-136. 1998.

EZQUERRA, J. M.; GARCÍA-CARREÑO, F. L.; CIVERA, R.; HAARD, N. F. pH-stat method to predict digestibility in vitro in white shrimp Penaeus vannamei. Aquaculture, v. 157, p. 249-260. 1997.

FAO. Fisheries and aquaculture software. FishStatJ - software for fishery statistical time series. In: FAO Fisheries and Aquaculture Department [online]. Rome. Released March 2016. Available at http://www.fao.org/fishery/statistics/software/fishstatj/en. 2016.

FLORES, S. E.; MARTINEZ, S. E. V. Critical operations on the manufacture of pelleted feeds for crustaceans. Aquaculture, v. 114, p. 83-92. 1993.

FORSTER, I. P.; DOMINY, W.; OBALDO, L.; TACON, A.G.J. Rendered meat and bone meals as ingredients of diets for shrimp Litopenaeus vannamei (Boone, 1931). Aquaculture, v. 219, p. 655-670. 2003.

FOX, J. M.; LAWRENCE, A. L.; LI-CHAN, E. Dietary requirement for lysine by juvenile Penaeus vannamei using intact and free amino acid sources. Aquaculture, v. 131, p. 279-290. 1995

GADIENT, M.; SCHAI, E. Leaching of various vitamins from shrimp feed. Aquaculture, v. 124, p. 201-205. 1994.

GIBTAN, A.; GETAHUN, A.; MENGISTOU, S. Effect of stocking density on the growth performance and yield of Nile tilapia [Oreochromis niloticus (L., 1758)] in a cage culture system in Lake Kuriftu, Ethiopia. Aquaculture Research, v. 39, p. 1450-1460. 2008.

GIVENS, D. I.; DEAVILLE, E. R. The current and future role of near infrared reflectance spectroscopy in animal nutrition: a review. Australian Journal of Agricultural Research, v. 50, p. 1131-1145. 1999.

GLENCROSS, B. D.; BOOTH, M.; ALLAN, G. L. A feed is only as good as its ingredients A review of ingredient evaluation for aquaculture feeds. Aquaculture Nutrition, v. 13, p. 17-34. 2007. 
GLENCROSS, B. D.; BOURNE, N.; RUTHERFORD, N. R.; HAWKINS, W. E.; BURRIDGE, P.; DODS, K.; SIPSAS, S.; SWEETINGHAM, M. Using NIRS to develop calibrations to predict the digestible protein and energy value of a feed grain - the lupin case study. Aquaculture Nutrition, v. 21, p. 54-62. 2015

HERTRAMPF, J. Quick method for crude fibre estimation. Feed Technology, 10.2.2006, p. 29-31. 2006.

HILTON, J. W.; CHO, S. J.; SLINGER, C. Y. Effect of extrusion processing and stream pelleting diets on pellet durability pellet water absorption and physiological response of rainbow trout, (Salmo gairdneri R.). Aquaculture, v. 25, p. 185-194. 1981.

HUNT, M. J.; WMSOR, H.; ALEXANDER, G. C. Feeding by penaeid prawns: the role of anterior mouth parts. Journal of Experimental Marine Biology and Ecology, v. 160, p. 33-46. 1992.

HYMOWITZ, T.; DUDLEY, J. W; COLLINS, F. I.; BROWN, C. M. Estimation of protein and oil concentration in corn, soybean, and oat seed by near-infrared light reflectance. Crop Science, v. 14, p. 713-715. 1974

JUSSILA, L.; EVANS, L. H. Growth and condition of marron Cherax tenuimanus fed pelleted diets of different stability. Aquaculture Nutrition, v. 4, p.143-149. 1998.

KAWASAKI, M.; KAWAMURA, S.; TSUKAHARA, M.; MORITA, S.; KOMIYA, M.; NATSUGA, M. Near-infrared spectroscopic sensing system for on-line milk quality assessment in a milking robot. Computers and Electronics in Agriculture, v. 63, p. 2227. 2008 .

KUMAR, R.; CHOUDHARY, V.; MISHRA, S.; VARMA, I. K.; MATTIASON, B. Adhesives and plastics based on soy protein products. Industrial Crops and Products, v. 16(3), p. 155-172. 2002.

KURESHY, N.; DAVIS, D. A. Protein requirement for maintenance and maximum weight gain for the Pacific white shrimp, Litopenaeus vannamei. Aquaculture, v. 204, p. $125-$ 143. 2002.

LACERDA, L. D.; VISMAN, A. G.; MAIA, L. P.; SILVA, C. A. R.; CUNHA, E. M. S. Relative importance of nitrogen and phosphorus emissions from shrimp farming and other anthropogenic sources for six estuaries along the NE Brazilian coast. Aquaculture, v. 253, p. 433-446. 2006.

LAWRENCE, A. L.; ARANYAKANANDA, P.; CASTILLE, F. L. Estimation of Dietary Protein and Energy Requirements for Shrimp. Proceedings, American Oil Chemists Association (AOCS) Conference, San Antonio, Texas, Inform v. 6, n. 4, p. 520- 521. 1995.

LAWRENCE, A. L.; LEE, P. G. Research in the Americas. In Crustacean Nutrition, Advances in World Aquaculture, Volume 6. World Aquaculture Society, Baton Rouge, USA, p. 566-587. 1997. 
LAZO, J. P.; DAVIS, D. A. Ingredient and feed evaluation. In: Encyclopedia of Aquaculture (Stickney, R.R. ed), pp. 453-463. John Wiley \& Sons, New York. 2000.

LEARY, D. F.; LOVELL, R. T. Value of fiber in production-type diets for cannel catfish. Transactions of the American Fisheries Society, v. 2, p. 328-332. 1975.

LEMOS, D.; LAWRENCE, A. L.; SICCARDI III, A. J. Prediction of apparent protein digestibility of ingredients and diets by in vitro $\mathrm{pH}$-stat degree of protein hydrolysis with species-specific enzymes for juvenile Pacific white shrimp Litopenaeus vannamei. Aquaculture, v. 295, p. 89-98. 2009.

LEMOS, D.; NAVARRETTE DEL TORO, A.; CÓRDOVA-MURUETA, J. H., GARCÍACARREÑO, F. Testing feeds and feed ingredients for juvenile pink shrimp Farfantepenaeus paulensis: in vitro determination of protein digestibility and proteinase inhibition. Aquaculture, v. 239, p. 307-321. 2004.

LEMOS, D.; NUNES, A. J. P. Prediction of culture performance of juvenile Litopenaeus vannamei by in vitro ( $\mathrm{pH}$-stat) degree of protein hydrolysis with species-specific enzymes. Aquaculture Nutrition, v. 14, p. 181-191. 2008.

LEMOS, D.; TACON, A. G. J. A rapid low-cost laboratory method for measuring the in vitro protein digestibility of feed ingredients and feeds for shrimp. Aquaculture Asia Pacific Magazine, Mar/Apr, p. 18-21. 2011.

LIM, C.; DOMINY, W. D. Evaluation of soybean meal as a replacement for marine animal protein in diets for shrimp (Penaeus vannamei). Aquaculture, v. 87, p. 53-63. 1990.

LIU, J.; WANG, Z.; LIN, W. De-eutrophication of effluent waste water from fish aquaculture by using marine green alga Ulva pertusa. Chinese Journal of Oceanology and Limnology, v. 28, p. 201-208. 2010.

MOLES, P.; BUNGE, J. Shrimp farming in Brazil: an industry overview. Roma: FAO/WWF/NACA, 2002, 26 p. 2002

MOYANO, F. J.; SAENZ DE RODRIGAÑEZ, M. A.; DIAZ, M.; TACON, A. G. J. Application of in vitro digestibility methods in aquaculture: constraints and perspectives. Reviews in Aquaculture, v. 15, p. 223-242. 2015

MPA/IBGE (Ministério da Pesca e Aquicultura / Instituto Brasileiro de Geografia e Estatística). Available at http://www.ibge.gov.br. 2015

NATES, S. F.; TACON, A. G. J. Feed quality testing: measuring in vivo, in vitro digestibility. Global Aquaculture Advocate, v. 8, p. 44-45. 2005

NG, W. K.; CHONG, C. Y. An overview of lipid nutrition with emphasis on alternative lipid sources in tilapia feeds. In R.G. Bolivar, G.C. Mair \& K. Fitzsimmons eds. Proceedings of the Sixth International Symposium on Tilapia in Aquaculture, p. 241248. Bureau of Fisheries and Aquatic Resources, Manila, Philippines. 2004 
NUNES, A. J. P. Tilapia cage farm management in Brazil. Global Aquaculture Advocate, p. 12-15. 2010.

NUNES, A. J. P. Tilapia cage farm management in Brazil. International Aquafeed, v. 15, p. 16-17. 2012.

NUNES, A. J. P.; PAIVA, T. C.; CAVALCANTI, S. L. NIRS technology ensures shrimp feed quality at farm level. Global Aquaculture Advocate Magazine, St. Louis, Missouri, v. 18, p. 68-70. 2015.

OBALDO, L. G.; DIVAKARAN, S.; TACON, A. J. G. Method for determining the physical stability of shrimp feeds in water. Aquaculture Research, v.33, p. 369-377. 2002.

OBALDO, L. G.; TACON, A. G. J. Manufacturing different diet sizes and its effect on pellet water stability and growth of three size classes of Pacific white shrimp, Litopenaeus vannamei. Journal of Applied Aquaculture, v. 11, n. 4, p. 57-66. 2001.

PEARCE, C. M.; DAGGETT, T. L.; ROBINSON, S. M. C. Effect of binder type and concentration on prepared feed stability and gonad yield and quality of the green sea urchin, Strongylocentrotus droebachiensis. Aquaculture, v. 205, p. 301-323. 2002.

PUJOL, S.; PEREZ-VENDRELL, A.M.; TORRALLARDONA, D. Evaluation of prediction of barley digestible nutrient content with near infrared reflectance spectroscopy (NIRS). Livestock Science, v. 109, p. 189-192. 2007.

REDDY, H. R. V.; RAI, A.; ANNAPPASWAMY, T. S. Essentiality of vitamins for juvenile white shrimp, Penaeus indicus. The Israeli Journal of Aquaculture, v. 51, n. 3, p. 122133. 1999.

RINNE, R. W.; GIBBONS, S.; BRADLEY, J.; SIEF, R.; BRIM, C. A. Soybean protein and oil percentages determined by infrared analysis. U.S. Department of Agriculture, Agriculture Research Publication ARC-NC-26. 1975.

ROJAS, A.; WADSWORTH, S. A review of cage culture: Latin America and the Caribbean. In: Halwart, M., Soto, D., Arthur, J.R. (Eds.), Cage Aquaculture - Regional Reviews and Global Overview. FAO Technical Paper 498. FAO, Rome, 259 pp. 2007.

ROKEY, G. J.; PLATTNER, B.; SOUZA, E. M. D. Feed extrusion process description. Revista Brasileira de Zootecnia, 39, 510-518. 2010.

RUBENTHALER, G. L.; BRUINSMA, B. L. Lysine Estimation in Cereals by NIR. Crop Science., v. 18, p. 1039-1042. 1978.

RUSCOE, I. M.; JONES, C. M.; JONES, P. L.; CALEY, P. The effects of various binders and moisture content in pellet stability of research diets for freshwater crayfish. Aquaculture Nutrition, v. 11, p. 87-93. 2005.

SHENK, J. S.; WESTERHAUS, M. O. Calibration de ISI way. In: Davies, A. M. C., Williams, P. (Eds.), Near Infrared Spectroscopy: The Future Waves, NIR Publications, Chichester, West Sussex, UK, pp. 198-202. 1996. 
SHIAU, S. Y. Nutrient requirements of penaeid shrimps. Aquaculture, v. 164, p. 77-93. 1998.

SHIAU, S. Y.; YU, H. L.; HW A. S. The influence of carboxymethylcellulose on growth, digestion, gastric emptying time and body composition of tilapia. Aquaculture, v. 70, p. 345-354. 1988.

SILVA, D. J.; QUEIROZ, A. C. Análises de Alimentos (Métodos Químicos e Biológicos). 3a ed., Universidade Federal de Viçosa, Viçosa, MG, 235 pp. 2009.

SINDIRAÇÕES, 2015. Boletim informativo do setor. December, 2015. Available at: http://sindiracoes.org.br/. Access on March, 2016.

SMITH, D. M.; TABRETT, S. J. Accurate measurement of in vivo digestibility of shrimp feeds. Aquaculture, v. 232, p. 564-580. 2004.

SMITH, V. H.; TILMAN, G. D.; NEKOLA, J. C. Eutrophication: impacts of excess nutrient inputs on freshwater, marine, and terrestrial ecosystems. Environmental Pollution, v. 100, p. 179-196. 1999.

SUGIURA, S. H. Digestibility, In: STICKNEY, R. R. (Ed.), Encyclopedia of Aquaculture. John Wiley \& Sons, New York, p. 209-218. 2000.

TACON, A. G. J. Nutritional studies in crustaceans and the problems of applying research findings to practical farming systems. Aquaculture Nutrition, v. 1, p. 165-174. 1996.

TACON, A. G. J. Shrimp and feeding regimes in zero-exchange outdoor tanks. The Global Aquaculture Advocate, v. 3, n. 2, p. 15-16. 1999.

TACON, A. G. J. Standard Methods for the Nutrition and Feeding of Fish and Shrimp. Argent Laboratories Press, Redmond, WA, USA. 1990.

TACON, A. G. J. The nutrition and feeding of farmed fish and shrimp - A training manual. 3. Feeding methods. FAO Field Document 7/E, Brasilia/Brazil. 1988

TACON, A. G. J. Thematic Review of Feeds and Feed Management Practices in Shrimp Aquaculture. Report prepared under the World Bank, NACA, WWF and FAO Consortium Program on Shrimp Farming and the Environment. Work in Progress for Public Discussion. Published by the Consortium. 69 pp. 2002.

TACON, A. G. J.; FORSTER., I. P. Aquafeeds and the environment: policy implications. Aquaculture, v. 226, p. 181-189. 2003.

TACON, A. G. J.; JORY, D.; NUNES, A. Shrimp feed management: issues and perspectives. In M.R. Hasan and M.B. New, eds. On-farm feeding and feed management in aquaculture. FAO Fisheries and Aquaculture Technical Paper No. 583. Rome, FAO. p. 481-488. 2013.

TIBBETTS, S. M.; MILLEY, J. E.; ROSS, N. W.; VERRETH, J. A. J.; LALL, S. P. In vitro $\mathrm{pH}$-stat protein hydrolysis of feed ingredients for Atlantic cod, Gadus morhua. 1. Development of the method. Aquaculture, v. 319, p. 398-406. 2011. 
TRINO, A.; SARROZA, J. Effect of a diet lacking in vitamin and mineral supplements on growth and survival of Penaeus monodon juveniles in a modified extensive culture system. Aquaculture, v. 136, p. 323-330. 1995.

VAN BARNEVELD, R.; NUTTALL, J.; FLINN, P. C.; OSBORNE, B. NIR reflectance measurement of the digestible energy content of cereals for growing pigs. Journal of Near Infrared Spectroscopy, v. 7, p. 1-7. 1998

VELASCO, M.; LAWRENCE, A. L. Initial evaluation of shrimp vitamin requirements in laboratory tanks without water exchange. The Global Aquaculture Advocate, v. 3, n. 4, p. 23. 2000

WILLIAMS, P. C. Implementation of near-infrared technology. In: Williams, P.C., Norris, K.H. (Eds.), Near-Infrared Technology in the Agricultural and Food Industries, AACC, Inc., St. Paul, Minnesota, USA, p. 145-171. 2001.

XIE, F. J.; ZENG, W. P.; ZHOU, Q. C.; WANG; H. L.; WANG, T.; ZHENG, C. Q.; WANG, Y. L. Dietary lysine requirement of juvenile Pacific white shrimp, Litopenaeus vannamei. Aquaculture, v. 358-359, p. 116-121. 2012.

YASUMARU, F.; LEMOS, D. Species-specific in vitro protein digestion (pH-stat) for fish: method development and application for juvenile rainbow trout (Oncorhynchus mykiss), cobia (Rachycentron canadum), and Nile tilapia (Oreochromis niloticus). Aquaculture, v. 426-427, p. 74-84. 2014.

ZHOU, Q. C.; ZENG, W. P.; WANG, H. L.; WANG, T.; WANG, Y. L.; XIE, F. J. Dietary arginine requirement of juvenile Pacific white shrimp, Litopenaeus vannamei. Aquaculture, v. 364-365, p. 252-258. 2012. 


\section{CHAPTER 2}

Comparison of inert markers and feed processing method on the estimation of apparent nutrient digestibility in Pacific white shrimp Litopenaeus vannamei. 


\begin{abstract}
This study utilized four diets (one reference, two experimental cold pelleted, and one commercial extruded) to evaluate acid-insoluble ash (AIA) and chromic oxide $\left(\mathrm{Cr}_{2} \mathrm{O}_{3}\right)$ as inert markers and feed processing method (industrial extruded vs. laboratory cold pelleted) to determine apparent digestibility coefficient (ADC) of dry matter and crude protein of juvenile $L$. vannamei. The experimental system consisted of 28 conical tanks connected to a closed recirculating seawater system, with 60 shrimp per tank (initial stocking density of 125 shrimp per $\mathrm{m}^{3}$ ). Seven tanks were randomly assigned to each of the four treatments and experimental diets. Fecal matter was collected six times a day, continuously during seven weeks, five days a week. The best overall shrimp growth performance was observed in animals fed the commercial extruded feed, with final shrimp body weight $(15.5 \mathrm{~g})$, weight gain $(152 \%)$, and weight gain per week $(1.3 \mathrm{~g})$ significantly higher $(P<0.05)$ than the other treatments. Though the average FCR for the feed commercial extruded was significantly higher $(2.4 \pm 0.3)$ than other treatments, it was still high compared with industry standards. The estimated ADC results using AIA as marker were lower for both dry matter and crude protein, when compared with values obtained using $\mathrm{Cr}_{2} \mathrm{O}_{3}$ as a marker. At present most commercial shrimp feeds are manufactured using conventional steam pelleting technology, with extended pre and/or post-pellet conditioning so as to produce water stable feeds. This is the inverse with fish feeds where most of the feed companies are using extrusion technology. During the experimental period a trend of lower feed intake was observed for shrimp fed the commercial pelleted diet group than that for commercial extruded feed. The use of AIA as marker in digestibility studies is easy and simple in regards of determination, but difficult in that a high degree of precision and skill is needed during analysis for it. Most digestibility studies where AIA had not met the expectations of a suitable marker did not attribute this to marker failure, but to analytical inaccuracy due mainly to low ingredient AIA contents. The internal marker AIA within shrimp feeds and feces was analyzed by treating the ash residue with hydrochloric acid and gravimetrically measuring the insoluble content. Low AIA content $(0.18 \%)$ was obtained within the commercial feeds. On the basis of the present investigation, AIA has been shown to be an effective natural endogenous marker for digestibility trials with L. vanammei, however, for commercial feeds attention should be paid to feed AIA level.
\end{abstract}




\subsection{Introduction}

\section{Global shrimp farming}

The shrimp aquaculture industry represents one of the most lucrative and fastest growing segments of the global seafood business. Valued at US\$23.58 billion, worldwide farmed shrimp production was estimated at 4.58 million tones in 2014 , and it is growing at an average annual rate of $12.6 \%$ over the last 30 years (FAO, 2016). Furthermore, the Pacific white shrimp Litopenaeus vannamei is ranked first in terms of total farmed fish and crustacean production by value, reaching US\$18.46 billion in 2014 (FAO, 2016) (Figure 1).

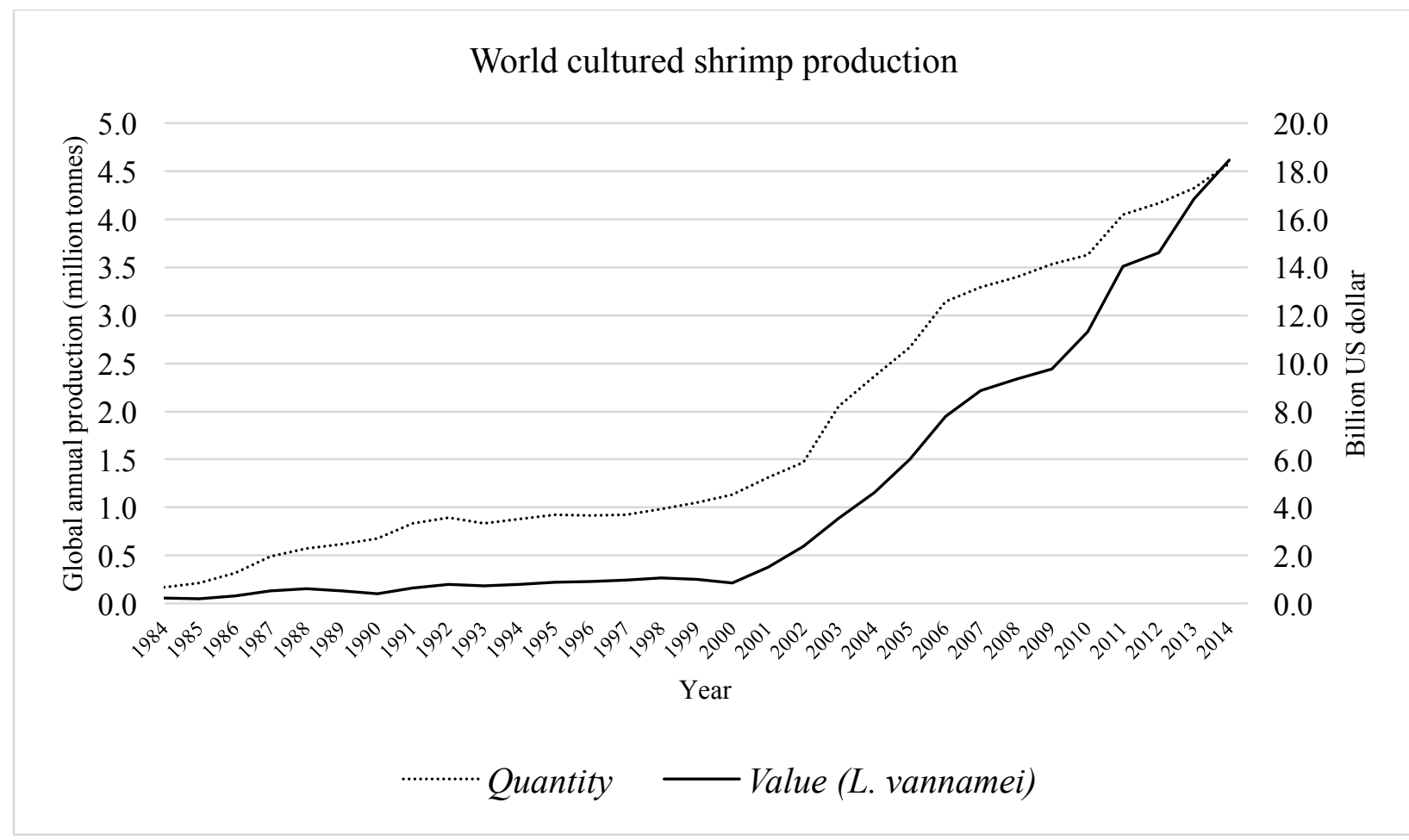

Figure 1 Global annual production (tonnes) of farm-raised shrimp (all species) and production value (US dollar) of L. vannamei over the last 30 years (FAO, 2016).

In this scenario, the production of animal food by aquaculture has grown faster than any other sector of agribusiness. The total production of aquafeeds in 2014 was estimated at 44.82 million tones of fish and shrimp feed. Shrimp feed production was approximately 6.62 million tones (FAO, 2016). 


\section{Shrimp digestion}

The gut in L. vannamei is basically a simple tube which runs the length of the body from the mouth to the anus at the end of the last somite. Enzyme secretion is limited to the midgut which is comprised of a large number of simple, fragile tubules. Dietary proteins are digested by proteinases such as trypsins and chymotrypins (LAN; PAN, 1993; CHEVALIER; WORMHOUDT, 1998), lipids by lipase and esterase activity while alpha-amylase and alphaglucosidase are secreted to digest carbohydrates (CHEVALIER; WORMHOUDT, 1998) under slightly-basic ( $\mathrm{pH}$ ) ) conditions (GARCIA-CARRENO et al., 1997). Once digested, nutrients are absorbed in the midgut and fecal formation and defecation takes place in the hindgut. This digestive scheme allows L. vannamei to be highly effective at digesting protein (AKIYAMA et al., 1989) even though it lacks pepsin and an acidic stomach.

\section{Nutrient digestibility}

Feed digestibility is a term used to describe only the portion of feed which "disappear" in the organism. The portion of protein and energy lost by the gut during ingestion and digestion are subtracted from the calculation and are commonly referred to as metabolic fecal nitrogen losses (MFN) and metabolic fecal energy (MFE) losses. Since it is difficult to determine these losses with any degree of accuracy using empirical methods (LEE; LAWRENCE ,1997) most nutritionists determine apparent digestibility. While apparent digestibility also describes the proportion of absorbed feed, it does not subtract losses associated with MFN and MFE as it is based on the difference between the proportion of nutrient ingested and in the feces. Although not a true measurement of digestibility, apparent digestibility still provides an accurate estimate of the ingredients or feeds digestibility.

The development and use of compound aquafeeds has been a major factor in the global expansion of shrimp farming, and efficient feed management is critical to maintain and improve the financial and environmental viability of the industry. The need for an appropriate method for determining nutrient digestibility in marine shrimp is critical to least cost feed formulation of commercial production feeds. Accurate nutrient availability data allow for more precise formulation of diets to meet nutritional requirements and improve cost substitution (i.e., least 
cost) of ingredients. Ultimately, this information could promote increased growth rate and survival, while reducing feed conversion ratio, feed cost, and pollution potential of feeds. Typically, indirect methods employing dietary markers are used for digestibility measurements in shrimp when maintained in tanks of varying dimensions and shapes. Their feces are collected either by siphoning or by sedimentation within a water column (CARVALHO et. al 2013). To determine apparent digestibility of nutrients by shrimp, most studies have used in vivo protocols and, in particular, using chromic oxide as dietary marker (AKIYAMA et al. 1989; DAVIS et al. 2002). Compared to most fish species, in vivo digestibility determination in shrimp is more challenging because of their benthic behavior which makes it difficult to use conical shaped tanks. Being slow feeders and coprophagous, the removal of feed and feces is complicated, resulting in rapid leaching from the feed and feces thus altering the marker to nutrient ratio, compromising the quality and the sampling efficiency of the shrimp feces.

\section{Inert markers}

Although chromic oxide has since been the most widely used inert marker in digestibility studies with shrimp, many efforts have been made to find alternatives to chromic oxide, either present in the feedstuffs (internal markers) or added to the diet (external markers). Of the indirect markers chromic oxide is the most widely used for studies involving L. vannamei (SMITH et al., 1985, AKIYAMA et al., 1989, DAVIS; ARNOLD, 1993; DAVIS et al., 2002). To produce valid results, the method relies upon the following assumptions:

1- The marker must pass through the gut at the same rate as the feed,

2- The marker must not be lost from the feces or absorbed from the gut of the shrimp,

3- The marker must be completely physiologically inert,

4- The ratio of nutrient to marker in the feed is the same as that ingested by the shrimp.

Some studies have questioned the interference of the chromic oxide in the ADC for lobster Homarus sp. (BORDNER et al., 1983; LEAVITT, 1985), freshwater crayfish Procambarus clarkii (BROWN et al., 1986) and caridean shrimp Pandalus serratus, Palaemon platyceros (FORSTER; GABBOT, 1971), and also for studies involving penaeid shrimp (SMITH; TABRETT, 2004; DIVAKARAN et al., 2000). AKIYAMA et al. (1989) reported 
chromic oxide levels were homogeneous in L. vannamei feces and achieved a low standard deviation between replicates which suggested the reproducibility of the indirect chromic oxide method. SMITH; TABRETT (2004) determined that a maximum of $3.4 \%$, but possibly less than $1 \%$ of chromic oxide was absorbed by the shrimp which would have a maximum underestimating effect of only $0.2 \%$ on apparent $\mathrm{CP}$ digestibility assuming the feed had an apparent dry matter digestibility of $80 \%$.

The use of internal markers, such as crude fiber, hydrolysis-resistant organic matter and acid-insoluble ash (AIA), has been recommended for measurement of ADC when possible (DE SILVA; ANDERSON, 1995). Acid-insoluble ash consists of indigestible mineral components, mainly silica. Silica has been used as early as 1874 as digestibility indicator (KOTB; LUCKEY, 1972), but is not widely used as marker at present due to its possible absorption from the gut and the risk, and, of contamination of feed with soil, especially with grazing animals (RYMER, 2000). Acid-insoluble ash contents of feeds and feces are determined gravimetrically after drying, ashing, boiling of ash in hydrochloric acid $(\mathrm{HCl})$, filtering and washing of the hot hydrolysate, and re-ashing.

Acid-insoluble ash as inert marker has been validated for use in mammals (VAN KEULEN; YOUNG, 1977), poultry (VOGTMANN et al., 1975), and penaeid shrimp (DEERING et al., 1996). It has been used as an internal marker in tilapia and other cichlids (BOWEN, 1981; DE SILVA; PERERA, 1983; DE SILVA et al., 1984), and rainbow trout (PERERA et al., 1995). When internal AIA is not present in sufficient quantity for accurate measurement in food samples it has been supplemented with external sources. Celite ${ }^{\circledR}$, an acidwashed, diatomaceous silica powder (ATKINSON et al., 1984; AZEVEDO et al., 1998; MORALES et al., 1999) and acid-washed sand (TACON; RODRIGUES, 1984) have been used as external sources of AIA in digestibility studies with rainbow trout. Results obtained using AIA in fish digestibility studies are contradictory. For example, with rainbow trout, AIA has been reported to give similar (ATKINSON et al., 1984), higher (MORALES et al., 1999) and lower values of digestibility coefficients (PERERA et al., 1995) than were determined using chromic oxide. Also, impractical digestibility values with the use of AIA as marker has been assigned to analytical imprecision due to a low dietary and fecal AIA content that introduced a large margin of error to the calculation (VAN KEULEN; YOUNG, 1977; JONES; DE SILVA, 
1998). THONNEY et al. (1985) recommended that the dietary AIA content should exceed $0.75 \%$ on a dry matter basis in order to get accurate measurements and that appropriate diets should contain certain plant tissues that are high in AIA. In several studies the AIA content of feeds has been increased by addition of exogenous sources of AIA. Thus, acid-insoluble ash could also be classified as an external marker.

\section{Objectives of this study}

1- Evaluate acid-insoluble ash (AIA) as inert marker to determine apparent digestibility coefficient (ADC) of dry matter and crude protein with L. vannamei fed practical and commercial diets, to ensure the applicability of the technique to the field (farms).

2- Assess the influence of feed preparation method (cold pelleted vs. industrial extruded) in the ADC of dry matter and crude protein with L. vannamei fed commercial diets. 


\subsection{Materials and Methods}

\section{Laboratory infrastructure}

The aquaculture system employed for running this digestibility study was based on the tank design of CARVALHO et al. (2013). The tank system was adapted to measure in vivo shrimp digestibility, which would combine efficient solids removal, reduced shrimp stress and optimize animal performance (Figure 2).

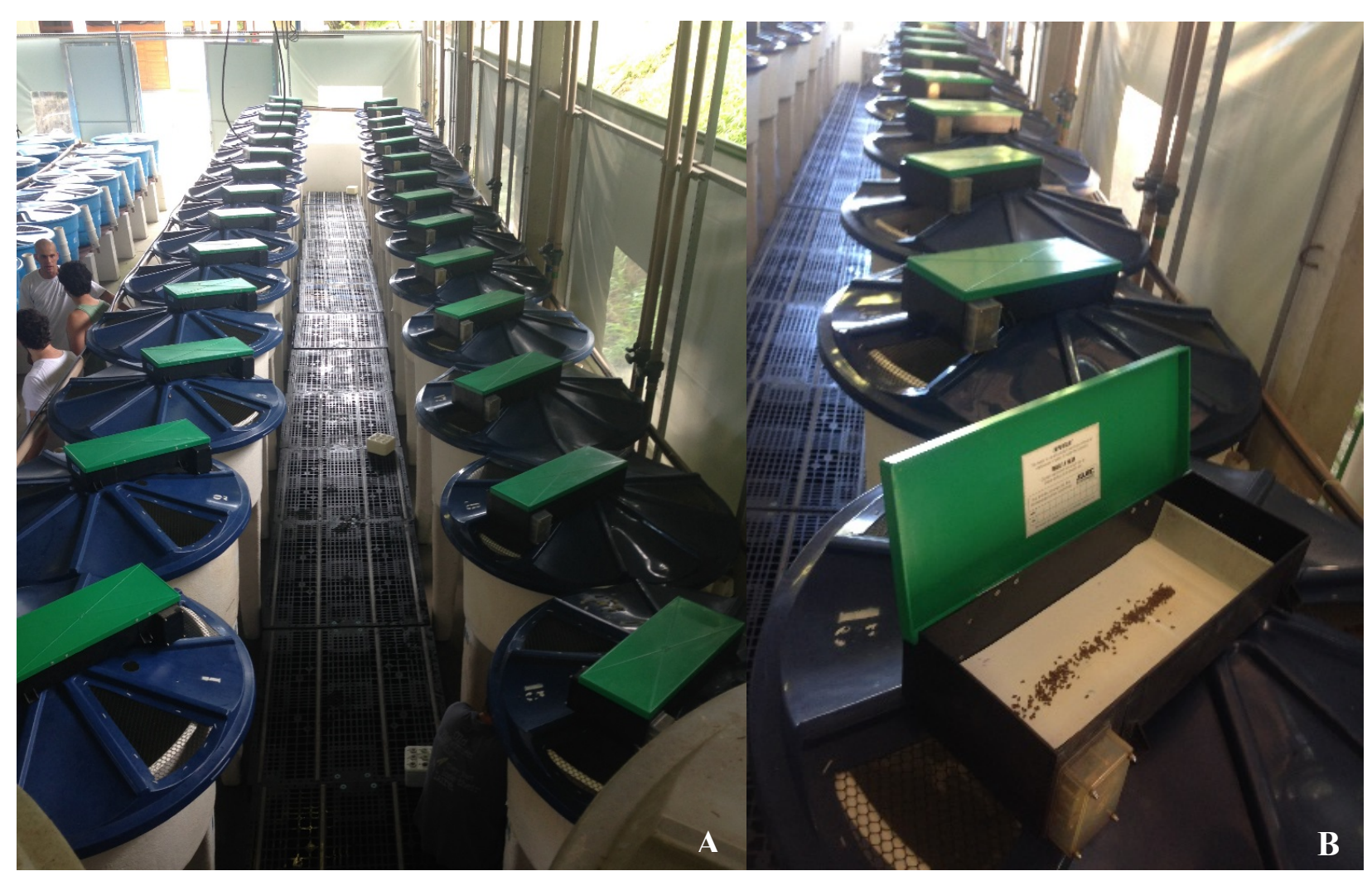

Figure 2 Shrimp digestibility system adapted from the original system according CARVALHO et al. (2013) (A). View of the automatic belt-feeder loaded with feed $(\boldsymbol{B})$.

The tank recirculation system, which could also be operated on an open flow basis, consisted of twenty-eight experimental round conical tanks (each of 500 L capacity), one effluent collection tank (2,000 L capacity), two header tanks (1,000 L each), and a filtration system having two 0.5 HP pumps, a sand filter for mechanical filtration, and a bead filter for biological filtration (Figure 3). Two titanium heaters and one flow heater were used to maintain seawater temperature at $29^{\circ} \mathrm{C}$ within the culture system. The layout of the recirculation system suited the 
space available in the Aquaculture Laboratory of the Oceanographic Institute in Ubatuba, São Paulo.

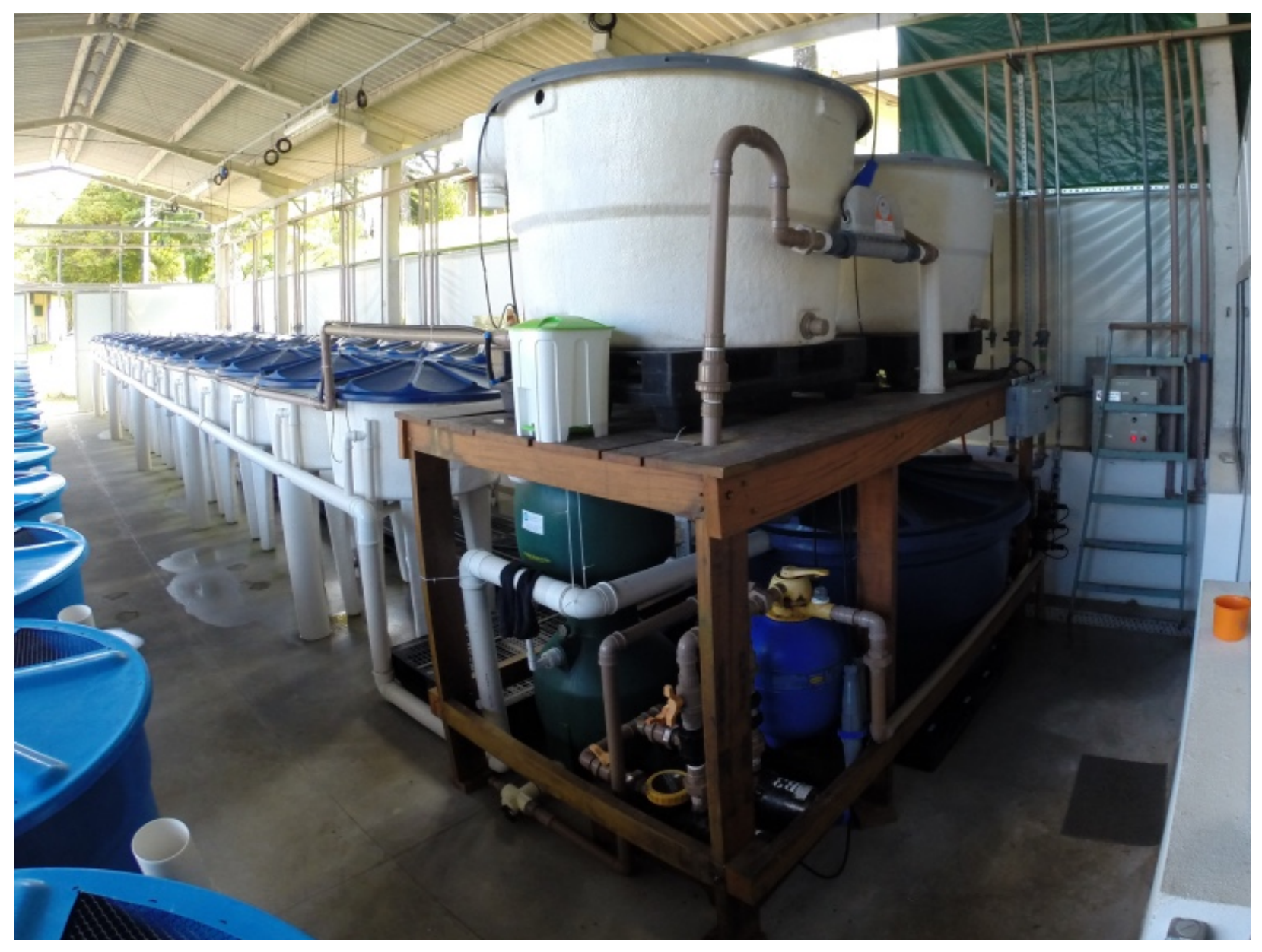

Figure 3 Overview of the closed recirculating system used for the digestibility trial with juvenile shrimp.

The digestibility system consisted of twenty-eight $500 \mathrm{~L}$ circular and slightly conical tanks made of reinforced fiberglass (Figure 4). The tanks frustum measured 1,000 and $960 \mathrm{~mm}$ (superior and inferior diameters) and $670 \mathrm{~mm}$ height. The bottom sloped $5^{0}$ toward the drain that measured $170 \mathrm{~mm} \times 50 \mathrm{~mm} \times 65 \mathrm{~mm}$ (upper and lower diameter plus height, respectively). The internal surface finish was a gel coat application and smooth polishing. The depth of the water in the tanks was $400 \mathrm{~mm}$ giving a volume of $0.4 \mathrm{~m}^{3}$ (tank diameter to water depth ratio of 2.5). 


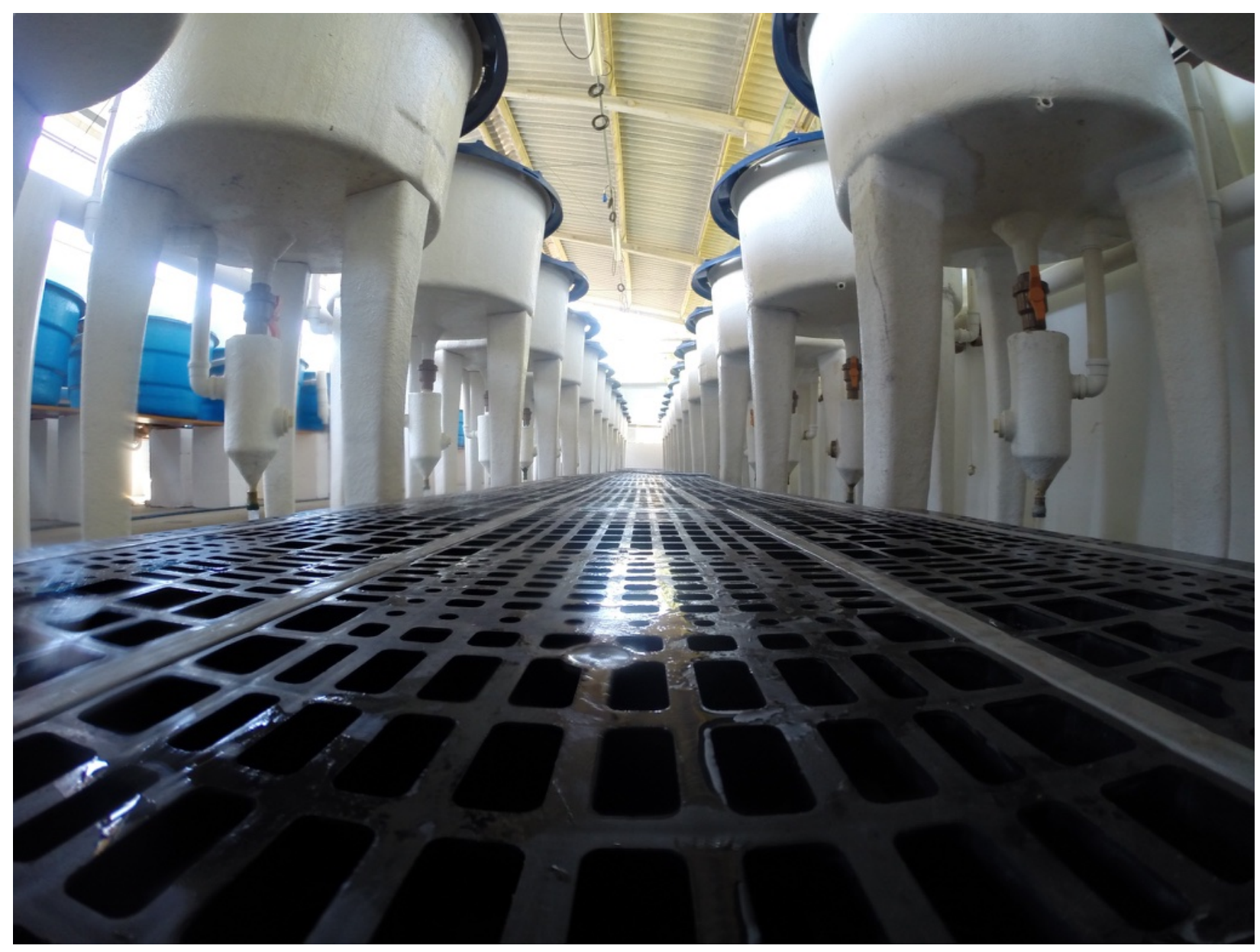

Figure 4 View of the bottom of the tanks system used for the digestibility study with shrimp juveniles.

The settling column was fixed to the tank drain by a $50 \mathrm{~mm} \times 50 \mathrm{~mm}$ PVC pipe beveled at its upper end which was glued to the bottom drain sleeve. The other end was glued to a $50 \mathrm{~mm}$ ball valve fixed to the settling column $(300 \mathrm{~mm} \times 150 \mathrm{~mm}$ in the trunk and $100 \mathrm{~mm} \times 150 \mathrm{~mm} \times$ $20 \mathrm{~mm}$ in the cone). The water with solids flows through a guide pipe directing the solids to the cone. The cleaner water leaves the column through a $50 \mathrm{~mm}$ elbow laminated in its superior part with its opening turned upwards to avoid the solids being carried away with the stream. The settling column had a volume of $8.9 \mathrm{~L}$ and dimensions of $400 \times 150 \mathrm{~mm}$ (height and diameter) with conical bottom and adapted for fitting a $50 \mathrm{ml}$ Falcon tube. Also, a $60 \mathrm{~mm}$ adapter with a plug was laminated into the column to allow access for cleaning purposes (Figure 5).

Each experimental tank had a polyethylene cover to reduce heat loss to the external environment, prevent the escape of animals and decrease lighting intensity inside the tanks (Figure 6). Three windows were made in each lid, covered by a plastic screen in order to observe 
the feeding behavior of the animals. Also, a $50 \mathrm{~mm}$ of diameter hole was made on each lid for feeding purpose.

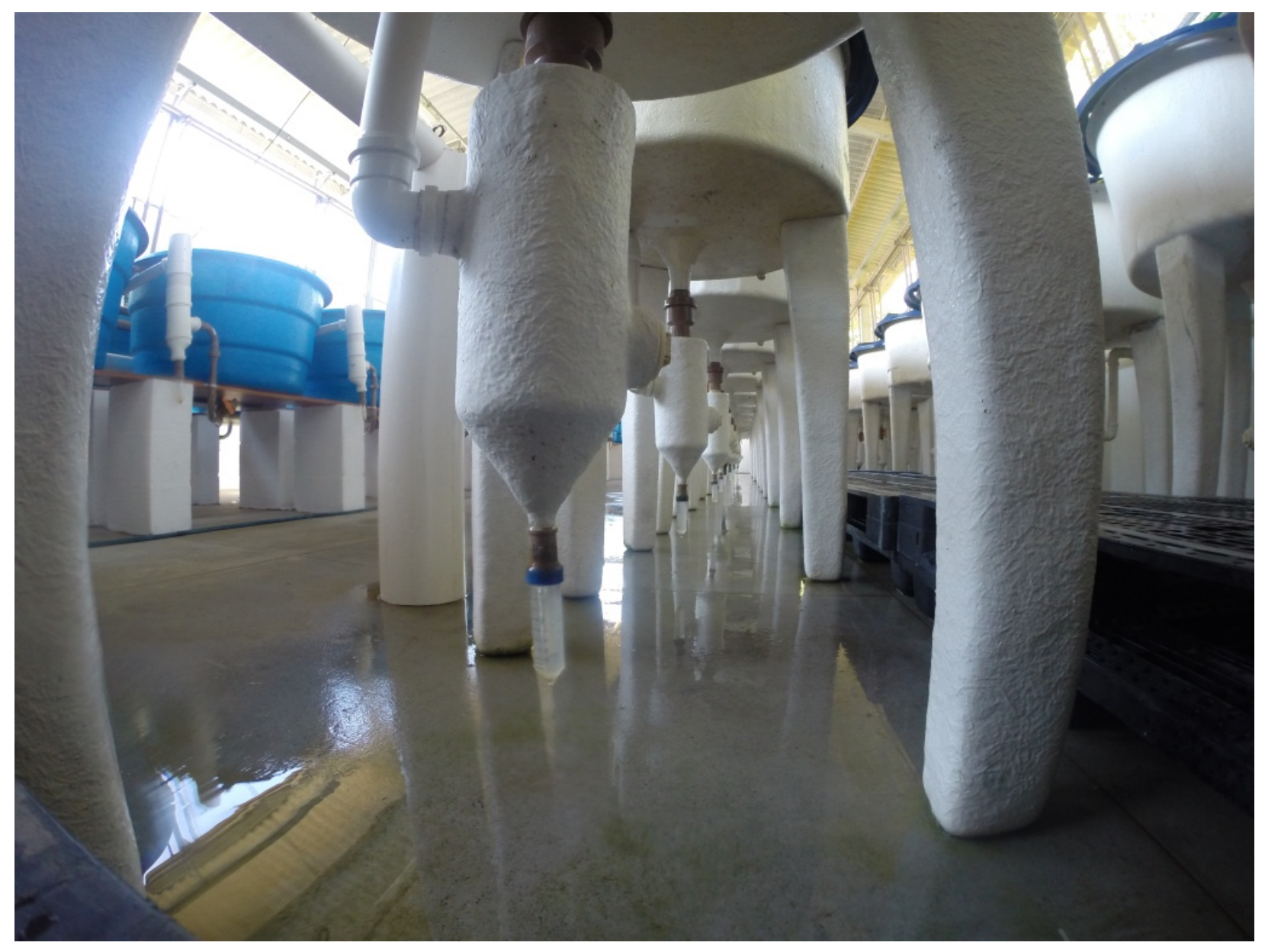

Figure 5 Settling column used for feces sampling and solids removal. 


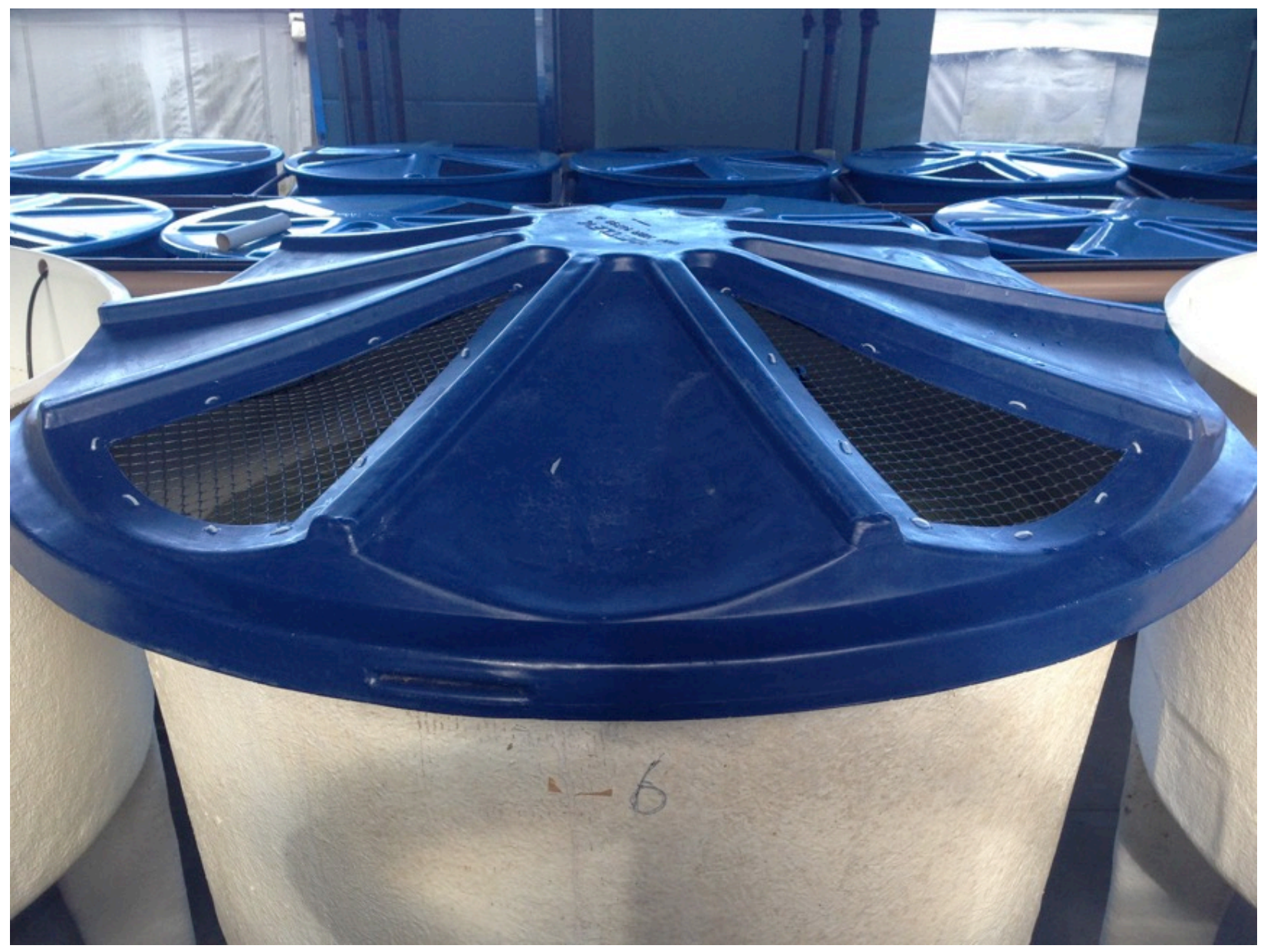

Figure 6 Polyethylene covers to reduce heat loss to the external environment, prevent the escape of animals and decrease lighting intensity inside the tanks.

The plumbing supply used PVC pipes for cold water, with $50 \mathrm{~mm}$ diameter pipes in the filtration system and $32 \mathrm{~mm}$ diameter pipes in the inflow of the tanks. For the drainage system, plastic sewer pipes of $100 \mathrm{~mm}$ in diameter were employed (Figure 7). 


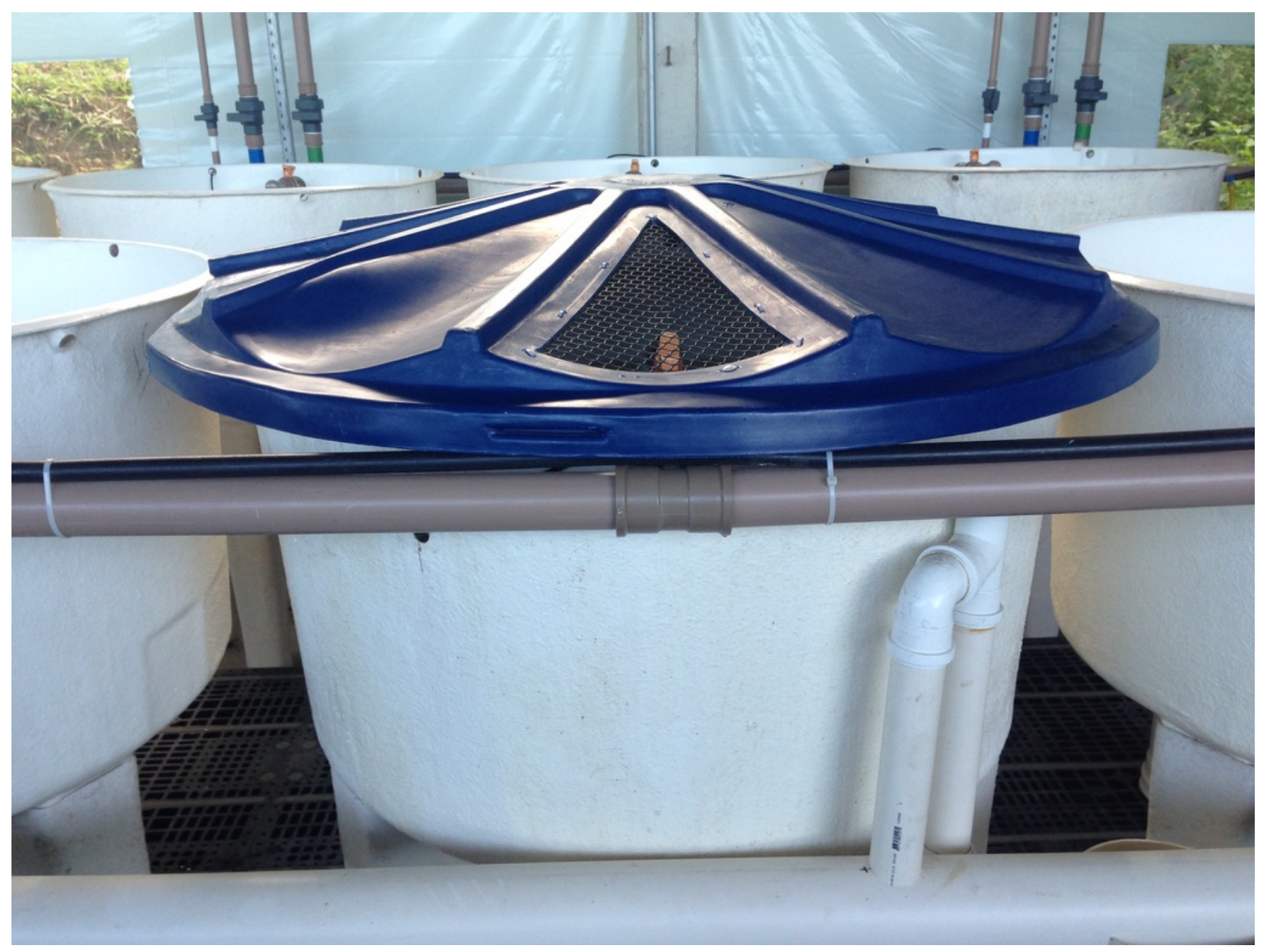

Figure 7 The plumbing supply consisted of PVC pipes with different diameters for income and effluent water.

The system consists of two reservoirs of 1,000 L capacity located $180 \mathrm{~cm}$ from the floor with a superior emergency spillway and two lower ball valve followed by $50 \mathrm{~mm}$ tubes, which supply water for the twenty-eight experimental tanks. Each experimental tank had a water inlet of $32 \mathrm{~mm}$ with ball valve to adjust the flow rate. The effluent water was then directed to a 2,000 L effluent tank positioned $15 \mathrm{~cm}$ off the floor. Water was pumped through the tanks using two pumps $(0.5 \mathrm{HP}$, three-phase) that work in alternating regimen, driven by an electronic buoy. When the supply reservoir is below the set level, the pump is driven and the effluent water from the reservoir is pumped through the sand filter, which performs the mechanical filtration and the bead filter, which performs the biological filter to fill the reservoir supply (Figure 9). Pumping is stopped when the effluent reservoir level is below the established to prevent air from entering the system.

The water collected directly from the sea is stored in three tanks of 10,000 L each. Before 
entering the system, the water passes through a cartridge filter of 5 and $25 \mu \mathrm{m}$, and an ultraviolet filter (Figure 8). The system is operated in closed recirculating and the refill of new water serves to replace losses caused by sampling, cleaning, evaporation and backwashing of filters.

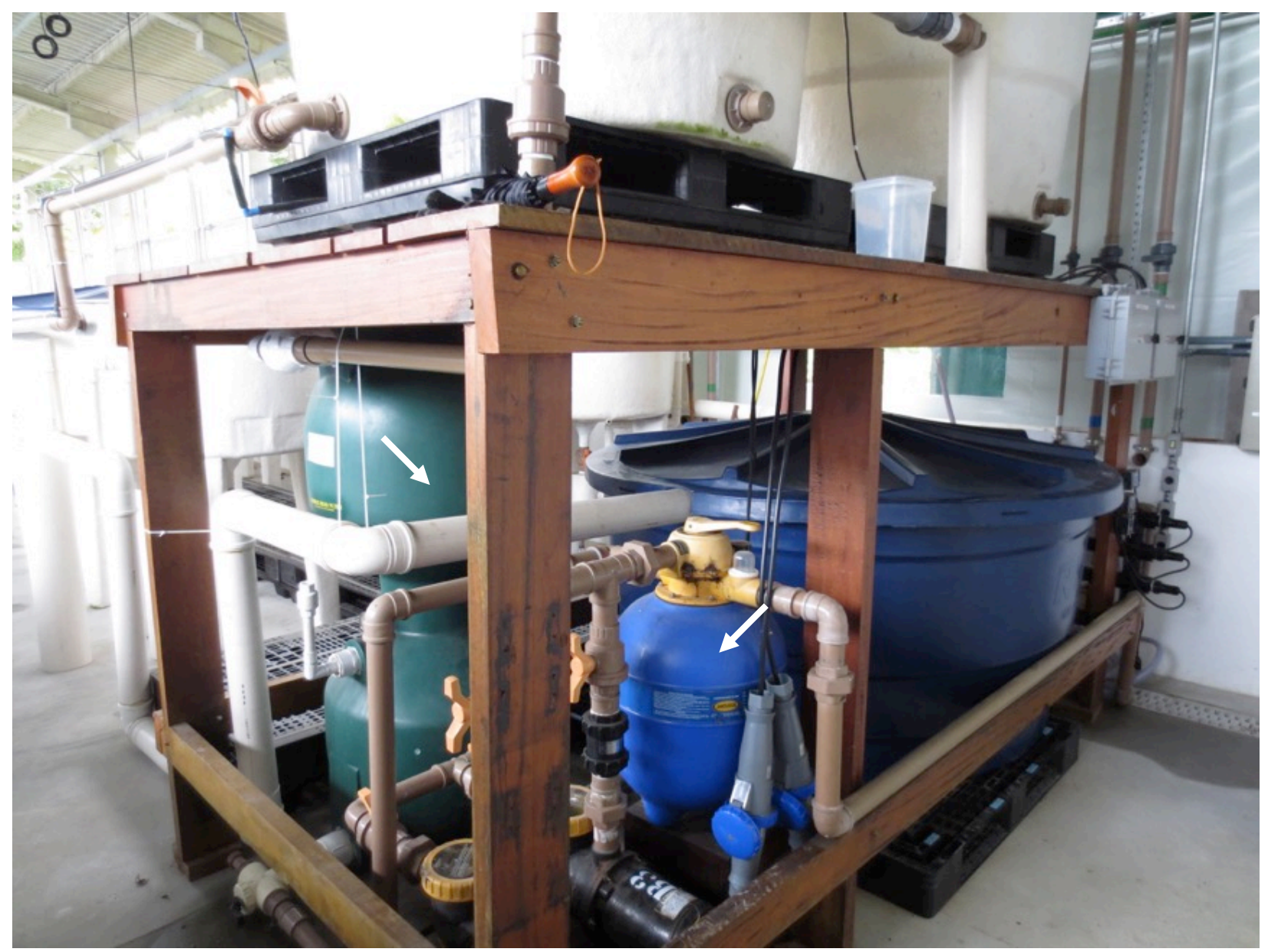

Figure 8 Water filtration system: sand filter (blue, right white arrow) and the bead filter (green, left white arrow), which performs the mechanical and biological filtration, respectively.

A 4 HP compressor installed in the machinery house provides the aeration of the experimental tanks. The pneumatic system consists of a galvanized iron pipe with $50 \mathrm{~mm}$ in the outlet of the compressor to $1.5 \mathrm{~m}$ away, where a junction was made with PVC pipe with $50 \mathrm{~mm}$ diameter, until the building. A polypropylene pipe with $1.22 \mathrm{~mm}$ of diameter was mounted in a ring on the edge of the experimental tanks, whereas an air hose is plugged with an air stone to supply air into each tank. An emergency system was installed to provide aeration in case of power failure or problems with the main compressor: two compressors of $0.3 \mathrm{HP}$ and a portable generator powered by diesel were available. 
The recirculation system has electric heaters distributed as follows: one immersion heater with a power of $1500 \mathrm{~W}$ with thermostats installed in each reservoir tank, and a flow heater with power of $1500 \mathrm{~W}$ installed after the bead filter. All three heaters combined are able to maintain the water temperature up to $30^{\circ} \mathrm{C}$. Wiring with different dimensions were necessary for the functioning of the system, connected to a main panel with main switch and two panels with breakers, distributed as follows: one general breakers, pumps frame and breaker protection DR for shutdown entire system in case of short circuits caused by accidents, two breakers for heaters and filters and ultra-violet, three breakers for lighting and outlets. The system has a set of two pumps that works with alternating regime, controlled by a three-phase panel.

\section{Feed preparation laboratory}

An experimental feed preparation laboratory was developed in the Aquaculture Laboratory of the Oceanographic Institute (University of São Paulo), located at the research and teaching facility in Ubatuba, SP. The laboratory is equipped with an industrial food mixer (Model ES-600, Hobart Manufacturing Corporation, Troy, OH, USA) used to blend the ingredients and cold-pellet the diets (Figure 9). There is a set of dies measuring between 1.0 to $10.0 \mathrm{~mm}$ of diameter used for each specie/animal size (Figure 10). A drying cabinet was built using an air blower at $38^{\circ} \mathrm{C}$, able to dry up to $25 \mathrm{~kg}$ of feed overnight (Figure 11). Also, ancillary equipment for the feed preparation were acquired: sieves, ingredients storage containers, refrigerator, freezer, scales, food trays. For physical water stability tests of ingredients and feeds, there was a refrigerated and heating circulating water bath with a shaker (Model RSWB3222A, Lindberg/BlueM, Ashville, NC, USA) and a filtration apparatus with $0.7 \mu$ fiberglass filter (AP4004700, Millipore). The feed ingredients (Guabi Nutrição Animal, Campinas, SP, Brazil), vitamin and mineral premixes (DSM, São Paulo, SP, Brazil), were obtained from collaborating companies, targeting applied research. 


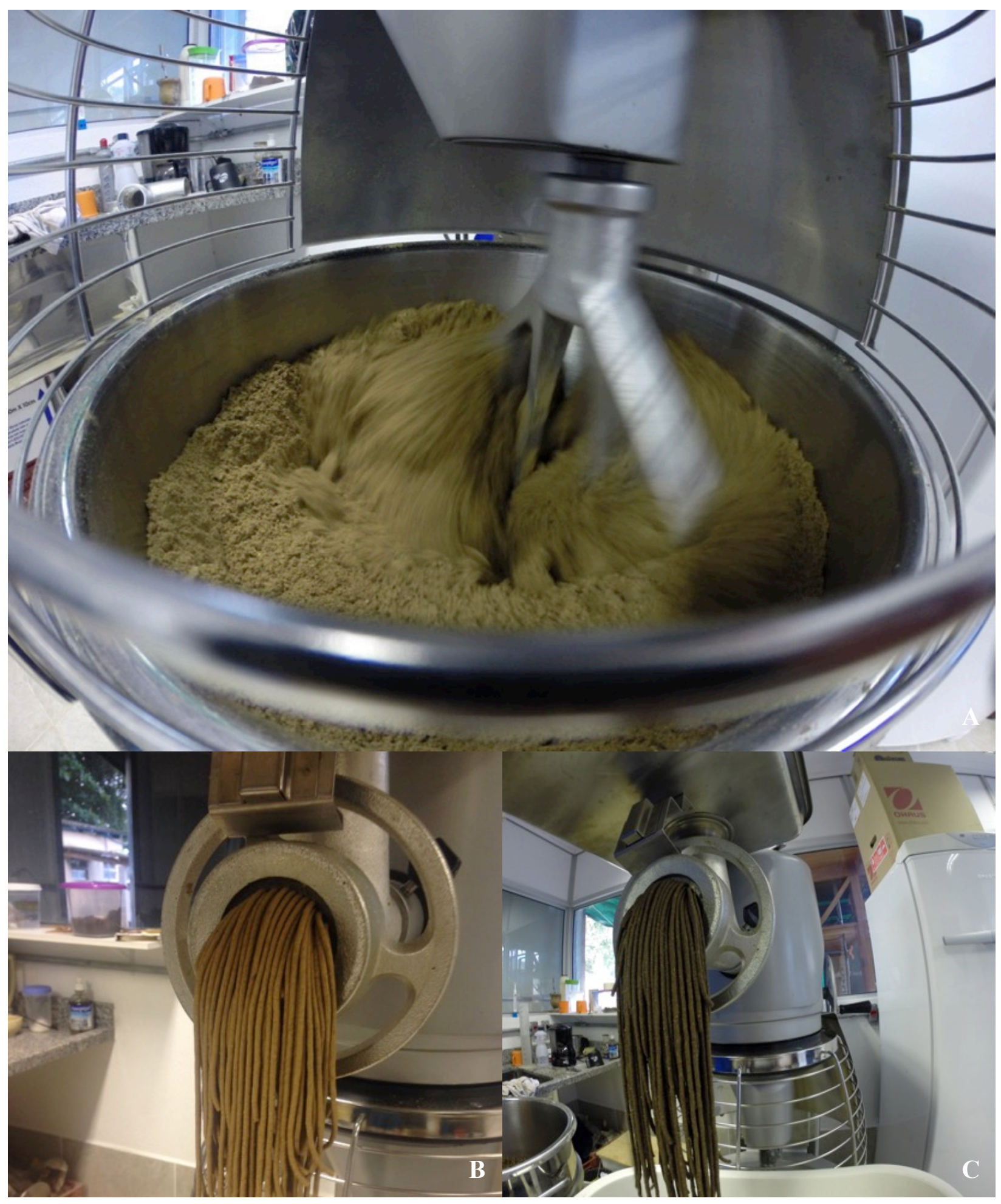

Figure 9 Industrial food mixer (A) used to blend the ingredients and cold-pellet the diets. Commercial mixture being cold pelleted (B); commercial mixture being cold pelleted with addition of the external marker chromic oxide $(\boldsymbol{C})$. 


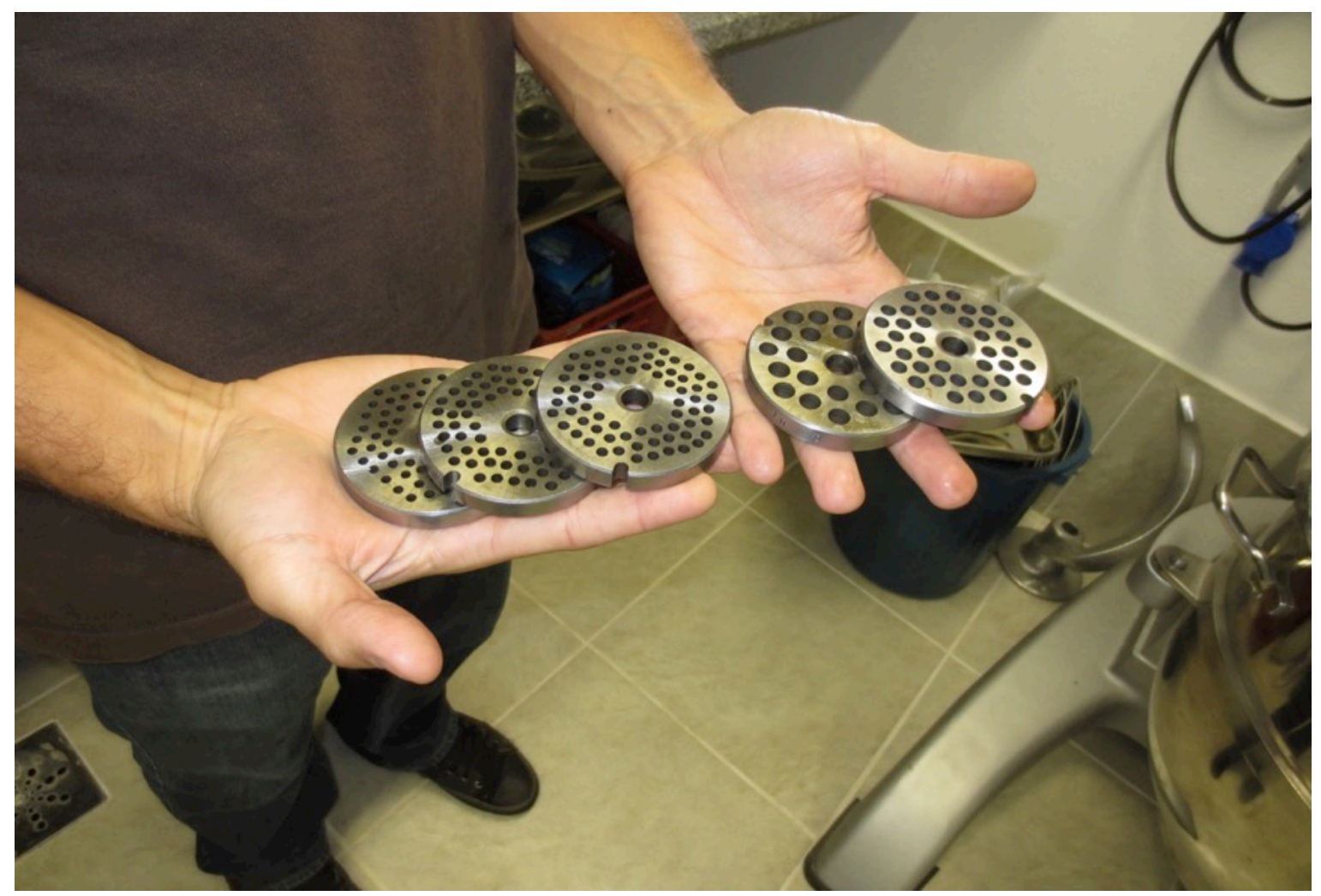

Figure 10 Set of dies measuring between $1.0 \mathrm{~mm}$ to $10.0 \mathrm{~mm}$ of diameter used for pelleting diets.

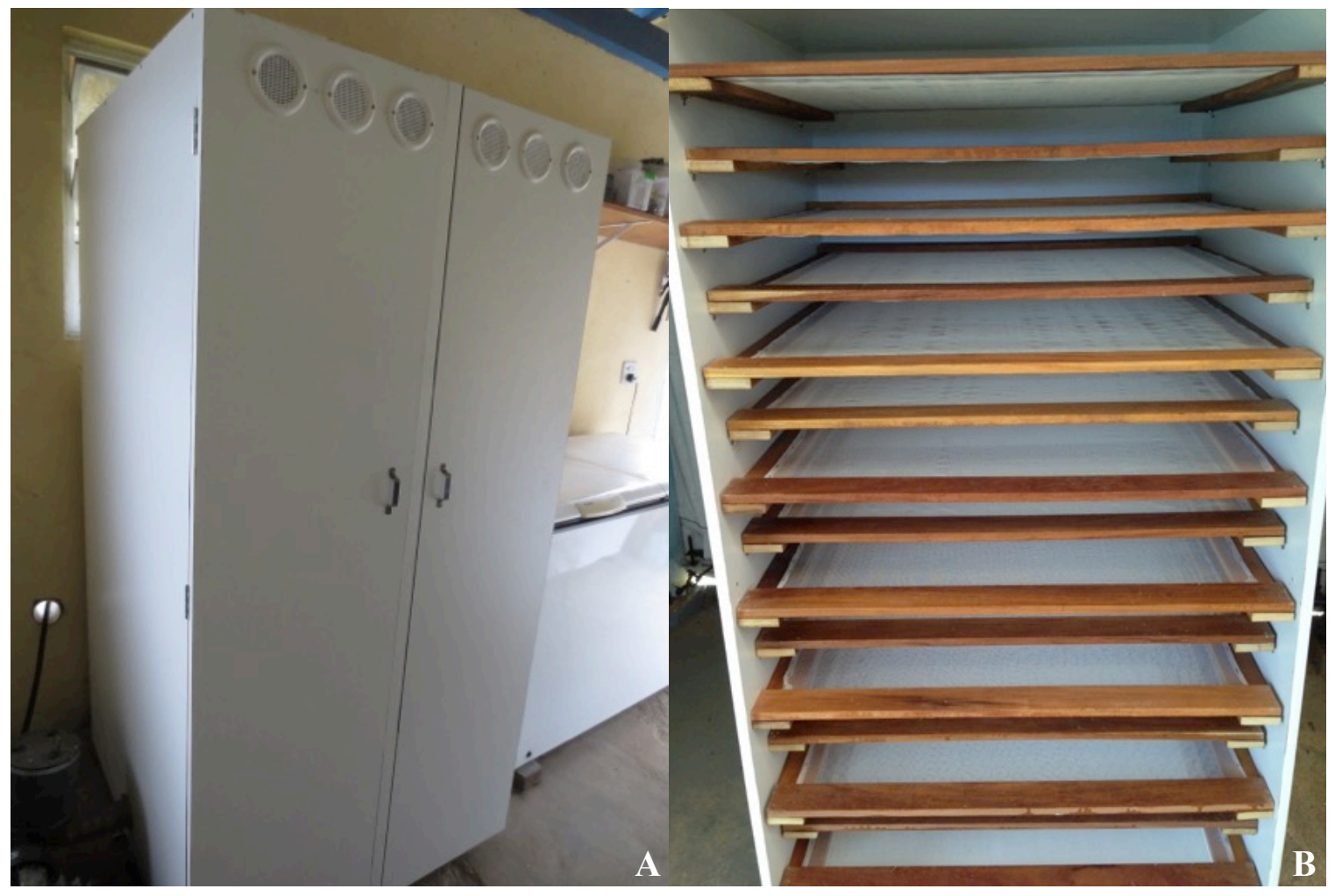

Figure 11 Drying cabinet built using an air blower at $38^{\circ} \mathrm{C}(\boldsymbol{A})$. View of the cabinet shelves accommodated alternately in order to let the air to flow and exit though the holes on top of the doors $(\boldsymbol{B})$. 


\section{Shrimp nursery}

Litopenaeus vannamei post-larvae (PL 10) were obtained from a commercial hatchery held at the northeast region of Brazil (Aquatec Aquacultura Ltda, Canguaretama, RN, Brazil). The animals were cultured for 20 days in two tanks of $1,000 \mathrm{~L}$ each in clear water and fed (Figure 12) exclusively with extruded commercial shrimp feed (40 Potimar PL, Guabi Nutrição Animal, Campinas, SP, Brazil) containing $40 \%$ of crude protein and $7.5 \%$ of lipid (declared values), using two automatic belt-feeders with operating cycle of 20 hours (Model Baby Belt Feeder, Aquatic Ecosystems, EUA). Around one third of the water was syphoned and replaced every day, removing feces and leftover feed. During the nursery phase, total ammonia nitrogen (TAN) and nitrite-nitrogen $\left(\mathrm{NO}_{2}-\mathrm{N}\right)$ concentrations were monitored using a commercial kit for salt water (Alfakit, Florianópolis, SC, Brazil). Shrimp were cultured in the nursery tanks for 20 days and then transferred to a heterotrophic indoor system (biofloc): 7,500 L tank with water salinity of $35 \mathrm{ppt}$, temperature of $27^{\circ} \mathrm{C}$ at a density of 210 animals $/ \mathrm{m}^{2}$. The levels of total suspended solids were maintained between 400 and $600 \mathrm{mg} \mathrm{L}^{-1}$ through its periodic removal by using 1.0 L conical settling chambers. The biofloc tank was operated with zero water exchange; however, water was added as needed to replace evaporative losses (approximately $5 \%$ per week). Shrimp were fed with commercial feed (35 Potimar EXT, Guabi Nutrição Animal, Campinas, SP, Brazil) containing $35 \%$ of crude protein and 7.5 of lipid (declared values), until they reached an average weight of $6.0 \mathrm{~g}$ and then stocked in the experimental tanks. 


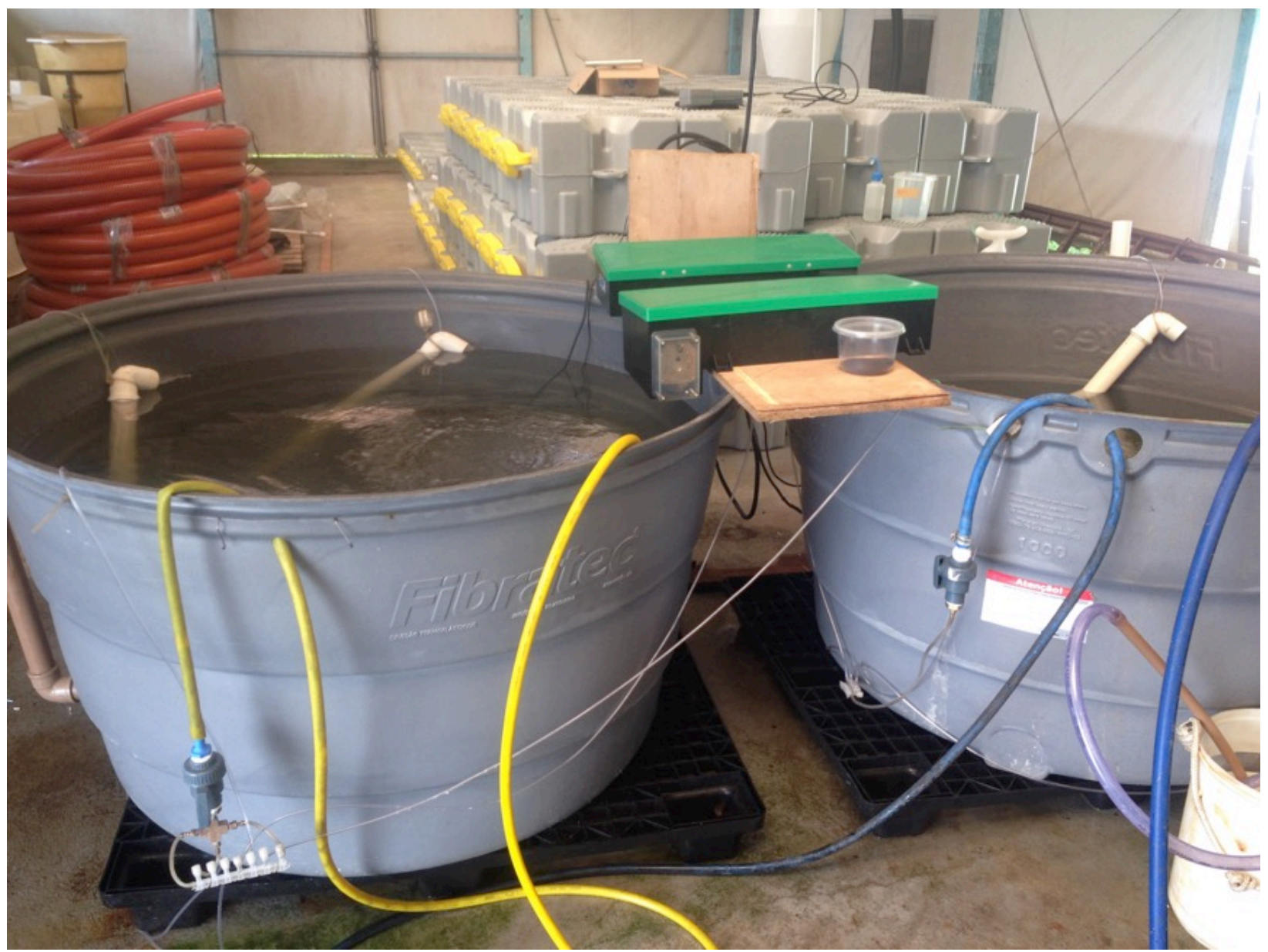

Figure 12 Tanks of 1,000 L each used for the nursery phase, with shrimp fed commercial feed, using two automatic belt-feeders. Shrimp were cultured in the nursery tanks for 20 days and then transferred to a heterotrophic indoor system (biofloc). 


\section{Experimental and commercial diets}

The main criteria used for the ingredient selection of the reference diet (Aquamar Shrimp) was their market availability and application in the manufacture of commercial marine shrimp diets in Brazil. The feed ingredients chosen included animal feed ingredients: fish meal (Brazilian), poultry by-product meal, squid meal, and blood meal, and plant based ingredients: soybean meal, and wheat flour. The proximate and amino acid composition of the ingredients are presented in Table 1. Besides the reference diet, one commercial extruded diet and two experimental diets were tested. A local feed manufacturer provided the feed Commercial Extruded, and also the commercial mixture (dry and liquid parts already weighed) used in the preparation of both cold pelleted diets Commercial Pelleted and Commercial Pelleted $+\mathrm{Cr}_{2} \mathrm{O}_{3}$. The dry part $(10 \mathrm{~kg}$, supposedly the same used in the manufacture of the diet Commercial Extruded) was mixed with the liquid part in the industrial food mixer, and processed as described previously. For the Commercial Pelleted $+\mathrm{Cr}_{2} \mathrm{O}_{3}$, it was added $0.5 \%$ of chromium oxide. The formulation and composition of the experimental diet Aquamar Shrimp is shown in Table 2, and the proximate composition of the three commercial diets are shown in Table 3. In summary, four different shrimp feeds were tested for the digestibility feeding trial, as follows:

1- Aquamar Shrimp: laboratory cold-pelleted experimental diet,

2- Commercial extruded: extruded commercially manufactured diet,

3- Commercial pelleted: in-house prepared from commercial mixture,

4- Commercial pelleted $+\mathrm{Cr}_{2} \mathrm{O}_{3}$ : in-house prepared from commercial mixture with addition of an external marker (chromic oxide) for digestibility assessment.

All the nutrients and amino acids in the experimental diet were formulated at levels considered to be adequate for marine shrimp (NRC, 2011). The micro ingredients (vitamin and mineral premix, and external marker - chromic oxide) were mixed in a portion of $0.5 \mathrm{~kg}$ of wheat flour and added to an industrial food mixer (Model ES-600, Hobart Manufacturing Corporation, Troy, OH, USA) and mixed/homogenized for 10 minutes (Figure 13). Then, the macro ingredients (fish meal, squid meal, blood meal, poultry by products meal, soybean meal, sugar cane yeast and wheat flour) were added and mixed for an additional 15 minutes. Finally, the liquid ingredients (fish oil, soy lecithin, fish hydrolysate and approximately $25 \%$ of distilled 
water) were added, and the feed mixed for an additional 15 minutes. The homogeneous mass was then transferred to an accessory meat grinder/extruder equipped with a $2 \mathrm{~mm}$ die and the resulting in the production of moist feed pellets which were then scattered over a dryer shelf and manually broken into smaller pieces $(2-4 \mathrm{~mm})$ (Figure 13). The shelves were placed in the drying cabinet, and the feed dried overnight until the moisture level was less than $10 \%$. The internal (die) temperature of the pelleting was $37.5^{\circ} \mathrm{C}$, and inside the drying cabinet was $38^{\circ} \mathrm{C}$. The dried pellets were then placed in polypropylene bags and excess air was removed to then be stored in a freezer at $-15^{\circ} \mathrm{C}$ for later use. Soybean meal was the only grounded ingredient, using a hammer mill (Model MCS 280, Moinhos Vieira, Tatui, SP, Brazil) such that it passed through a $250 \mu \mathrm{m}$ screen. The others ingredients were supplied in fine flour $(<500 \mu \mathrm{m})$ forms and required no further milling.

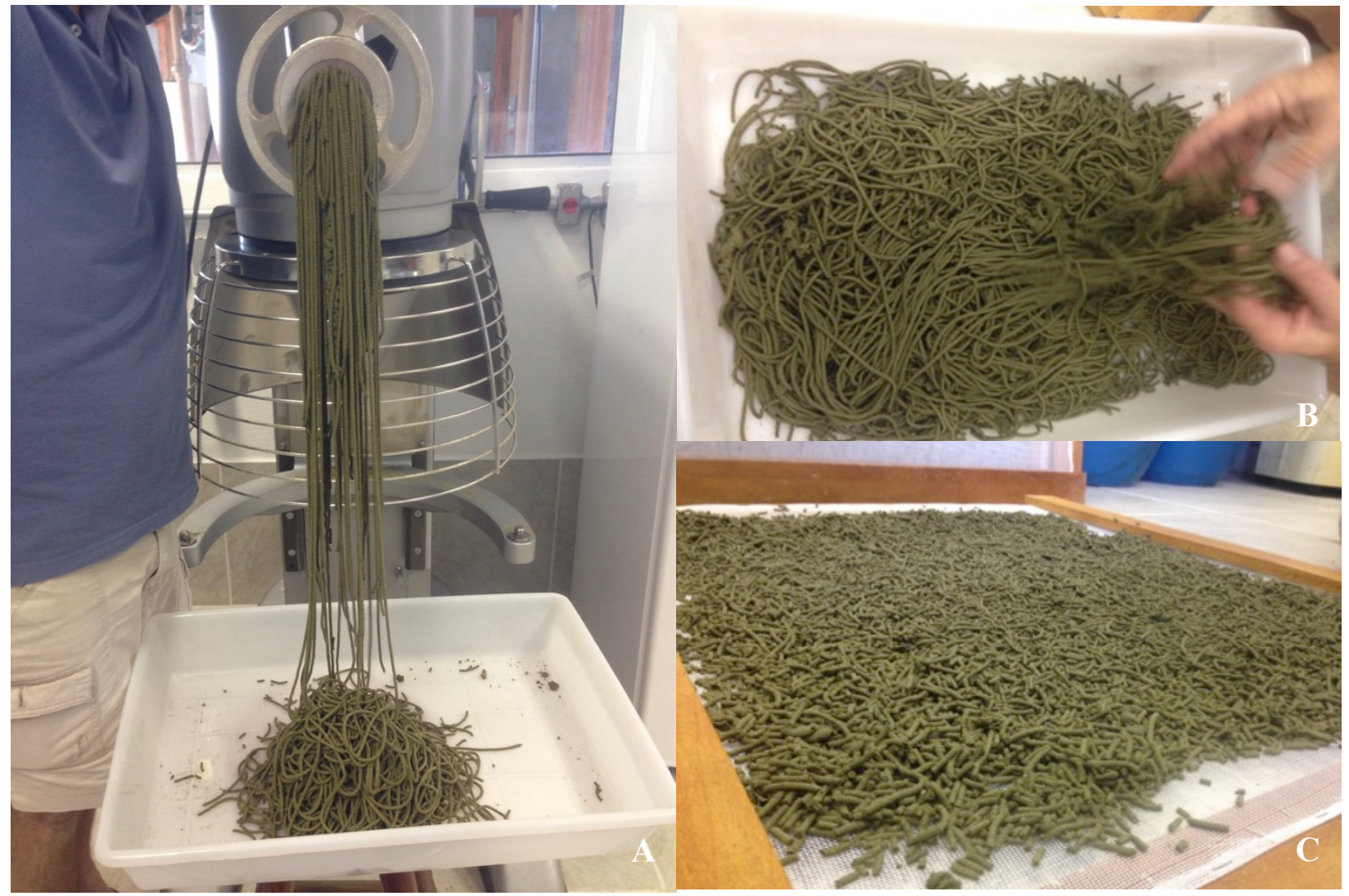

Figure 13 Moist pellets feed being prepared in the industrial mixer (A), which were then scattered and manually broken into smaller pieces $(\boldsymbol{B})$. The feed was placed over the dryer shelf, and then dried overnight until the moisture level was between $6.5-7.5 \%(\boldsymbol{C})$. 
Table 1 - Proximate and amino acid composition of the main ingredients used in the manufacture of the experimental diet "Aquamar Shrimp".

\begin{tabular}{|c|c|c|c|c|c|c|c|}
\hline Proximate composition (\%, as fed basis) & Fish meal $^{1}$ & $\begin{array}{l}\text { Poultry by- } \\
\text { product } \\
\text { meal }^{2}\end{array}$ & Squid meal $^{2}$ & Blood meal $^{2}$ & Wheat flour ${ }^{2}$ & $\begin{array}{l}\text { Soybean } \\
\text { meal }^{2}\end{array}$ & Dried yeast $^{2}$ \\
\hline Moisture & 8.57 & 4.99 & 3.66 & 2.43 & 10.38 & 10.36 & 5.13 \\
\hline Crude protein & 59.20 & 49.59 & 86.56 & 98.91 & 14.50 & 46.66 & 40.29 \\
\hline Crude fat & 11.37 & 17.47 & 4.86 & 1.53 & 2.59 & 3.92 & 1.97 \\
\hline Crude fiber & 0.50 & 0.66 & 1.75 & 0.50 & 0.69 & 4.88 & 0.50 \\
\hline Ash & 16.68 & 26.74 & 3.66 & 1.79 & 1.18 & 6.74 & 3.62 \\
\hline $\mathrm{NFE}^{3}$ & 3.68 & 0.55 & - & - & 70.66 & 27.44 & 48.49 \\
\hline Calcium $(\mathrm{Ca})$ & 3.96 & 4.96 & 0.07 & 0.07 & 0.03 & 0.30 & 0.12 \\
\hline Phosphorus (P) & 2.76 & 2.47 & 0.67 & 0.09 & 0.27 & 0.62 & 0.64 \\
\hline
\end{tabular}

Essential amino acids (\%, as fed basis)

\begin{tabular}{|c|c|c|c|c|c|c|c|}
\hline Arginine & 3.16 & 3.04 & 5.89 & 5.80 & 0.60 & 2.91 & 1.58 \\
\hline Histidine & 2.05 & 0.72 & 1.94 & 5.10 & 0.33 & 1.16 & 0.91 \\
\hline Isoleucine & 2.03 & 1.57 & 3.23 & 3.60 & 0.50 & 1.83 & 1.92 \\
\hline Leucine & 3.79 & 3.13 & 6.40 & 10.40 & 0.94 & 3.46 & 2.92 \\
\hline Lysine & 4.20 & 2.27 & 7.08 & 8.30 & 0.36 & 2.88 & 3.16 \\
\hline Methionine & 1.40 & 0.78 & 2.42 & 0.73 & 0.17 & 0.20 & 0.45 \\
\hline Phenylalanine & 1.84 & 1.61 & 2.87 & 3.90 & 0.61 & 2.11 & 1.57 \\
\hline Threonine & 2.24 & 1.58 & 3.35 & 3.80 & 0.36 & 1.57 & 1.81 \\
\hline Tryptophan & - & - & - & - & - & - & - \\
\hline Valine & 2.19 & 2.06 & 3.05 & 6.70 & 0.54 & 1.74 & 2.18 \\
\hline Taurine & 0.46 & 0.09 & 0.46 & 0.12 & - & - & - \\
\hline \multicolumn{8}{|c|}{ Non-essential amino acids (\%, as fed basis) } \\
\hline Cystine & 0.61 & 1.19 & 1.48 & 0.81 & 0.29 & 0.61 & 0.08 \\
\hline Tyrosine & 1.38 & 1.01 & 2.67 & 2.70 & 0.19 & 1.07 & 0.82 \\
\hline Serine & 1.94 & 2.27 & 3.39 & 4.90 & 0.62 & 2.20 & 1.99 \\
\hline Aspartic Acid & 3.73 & 1.35 & 7.53 & 5.56 & 0.63 & 4.37 & 2.94 \\
\hline Glutamic Acid & 6.98 & 4.65 & 12.60 & 8.60 & 4.89 & 8.64 & 4.30 \\
\hline Proline & 2.69 & 3.65 & 3.83 & 3.57 & 1.55 & 2.29 & 1.45 \\
\hline Alanine & 3.41 & 2.94 & 4.52 & 6.10 & 0.48 & 1.83 & 2.43 \\
\hline
\end{tabular}

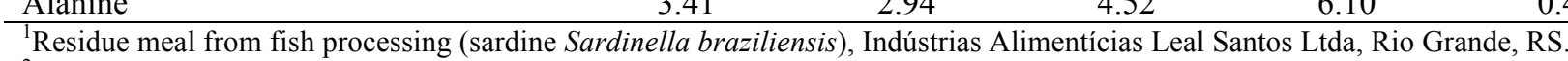

${ }^{2}$ Sourced by Guabi Nutrição Animal Ltda, Campinas, SP.

${ }^{3}$ Nitrogen-free extract calculated by difference: 100 - moisture - crude protein - ash - crude fat - fiber.

Dash indicates not determined or zero if not present. 
Table 2 - Formulation and proximate composition of the experimental diet "Aquamar Shrimp" fed to shrimp Litopenaeus vannamei during the 7 week indoor digestibility trial.

\begin{tabular}{|c|c|}
\hline Ingredients & $\%$ \\
\hline Fish meal (Brazilian) $^{1}$ & 20.0 \\
\hline Poultry by-product meal ${ }^{2}$ & 10.0 \\
\hline Squid meal $^{2}$ & 5.0 \\
\hline Blood meal $^{2}$ & 2.0 \\
\hline Wheat flour ${ }^{2}$ & 36.0 \\
\hline Soybean meal $^{2}$ & 15.0 \\
\hline Dried yeast $^{2}$ & 3.0 \\
\hline Fish oil ${ }^{2}$ & 2.0 \\
\hline Fish hydrolysate $^{3}$ & 4.0 \\
\hline Soybean lecithin oil ${ }^{2}$ & 1.0 \\
\hline Mineral and vitamin premix ${ }^{4}$ & 1.0 \\
\hline Nutribind $^{\circledR 5}$ & 0.5 \\
\hline $\mathrm{Cr}_{2} \mathrm{O}_{3}{ }^{6}$ & 0.5 \\
\hline \multicolumn{2}{|c|}{ Proximate composition (\%, as fed basis) } \\
\hline Moisture & $7.0(0.87)$ \\
\hline Crude protein & $35.0(0.12)$ \\
\hline Crude fat & $8.3(0.45)$ \\
\hline Crude fiber & 5.8 \\
\hline Ash & $10.8(0.10)$ \\
\hline $\mathrm{NFE}^{7}$ & 33.9 \\
\hline Energy $\left(\mathrm{MJ} \mathrm{kg}^{-1}\right)$ & 4181.0 \\
\hline \multicolumn{2}{|l|}{ Markers (\%, dry matter basis) } \\
\hline Chromic oxide $-\mathrm{Cr}_{2} \mathrm{O}_{3}$ & $0.51(0.01)$ \\
\hline Acid insoluble ash - AIA & $1.92(0.06)$ \\
\hline
\end{tabular}

Data are means \pm (s.d.) for 3 replicates.

${ }^{1}$ Residue meal from fish processing (sardine Sardinella braziliensis), Indústrias Alimentícias Leal Santos Ltda, Rio Grande, RS.

${ }^{2}$ Sourced by Guabi Nutrição Animal, Campinas, SP, Brazil.

${ }^{3}$ Diana Group, Even, France.

${ }^{4} \mathrm{DSM}$, São Paulo, SP, Brazil - consisted of ( $\mathrm{mg} / \mathrm{kg}$ premix) the following: ascorbic acid, 350.0; DL-calcium pantothenate 180.0; choline chloride, 750.0; inositol, 400.0; folic acid 12.0; biotin, 0.8; niacin, 120; vitamin A (9,000 UI/kg), ; vitamin D3 (2,500 UI/kg), ; vitamin E, 350.0; vitamin K3, 40.0; vitamin B1, 60.0; vitamin B2, 60.0; vitamin B6, 60.0; vitamin B12, 0.1; Se, 0.5; Cr, 0.5; Iron, 72.0; Cu, 24.0; Zinc, 80.0; Mg, 12.0; Iodine, 1.2; Cobalt, 0.5 .

${ }^{5}$ Nutriad Nutrição Animal, Campinas, SP, Brazil.

${ }^{6}$ Sigma, St Louis, MO, USA.

${ }^{7}$ Nitrogen-free extract calculated by difference: 100 - moisture - crude protein - ash - crude fat - crude fiber. 
Table 3 - Proximate composition of the experimental and commercial diets fed to shrimp Litopenaeus vannamei during 7 weeks indoor digestibility trial.

\begin{tabular}{|c|c|c|c|c|}
\hline \multirow{2}{*}{$\begin{array}{l}\text { Proximate composition } \\
(\%, \text { dry matter basis) }\end{array}$} & \multicolumn{4}{|c|}{ Diet } \\
\hline & Aquamar Shrimp $^{1}$ & Commercial Extruded $^{2}$ & Commercial Pelleted $^{3}$ & Commercial Pelleted $+\mathrm{Cr}_{2} \mathrm{O}_{3}{ }^{4}$ \\
\hline Moisture & $7.0(0.87)$ & $10.1(1.00)$ & $6.5(0.88)$ & $7.5(0.45)$ \\
\hline Crude protein & $35.0(0.12)$ & $35.7(0.55)$ & $39.5(0.21)$ & $38.5(0.38)$ \\
\hline Crude fat & $8.3(0.45)$ & $7.1(0.11)$ & $9.7(0.78)$ & $8.6(0.31)$ \\
\hline Crude fiber & 5.8 & 2.3 & 2.8 & 2.6 \\
\hline Ash & $10.8(0.10)$ & $12.1(0.26)$ & $12.4(0.19)$ & $12.6(0.46)$ \\
\hline $\mathrm{NFE}^{5}$ & 33.9 & 32.6 & 29.1 & 30.2 \\
\hline Energy $\left(\mathrm{MJ} \mathrm{kg}^{-1}\right)$ & 4181.0 & 3959.3 & 4078.5 & 4092.0 \\
\hline \multicolumn{5}{|c|}{ Markers (\%, dry matter basis) } \\
\hline $\mathrm{Cr}_{2} \mathrm{O}_{3}$ & $0.51(0.01)$ & - & - & $0.45(0.04)$ \\
\hline AIA & $1.92(0.06)$ & $0.18(0.01)$ & $0.18(0.00)$ & $0.61(0.02)$ \\
\hline
\end{tabular}

Data are means \pm (s.d.) for 3 replicates.

${ }^{1}$ Shrimp experimental pelleted diet.

${ }^{2}$ Shrimp extruded commercial diet.

${ }^{3}$ Shrimp in-house prepared dry pellet.

${ }^{4}$ Shrimp in-house prepared dry pellet + chromic oxide.

${ }^{5}$ Nitrogen-free extract calculated by difference: 100 - moisture - crude protein - ash - crude fat - crude fiber.

Dash indicates not determined or zero if not present. 


\section{Experimental design and feeding management}

The experimental system for this study consisted of 28 tanks (500 L) connected to a closed recirculating seawater system, as described in the item 2.2.1. A light:dark natural photoperiod (approximately 11 hour of light and 13 of dark) was provided. At the start of the experiment shrimps were counted, weighed in group (in water using a 20L plastic bucket) and stocked in group of 60 shrimp into each tank, maintaining an initial density of 125 shrimp per $\mathrm{m}^{-3}$. Seven tanks were randomly assigned to each of the four diets. Molts, and dead shrimp in each tank were removed daily prior to filling the automatic feeders (set to deliver $20 \mathrm{~h}$ continuous feed) with the appropriate experimental feed and quantity (Figure 14). Shrimps were fed in order to apparently satiate the animals and do not overfeed (let pellets goes through the drain). Initial quantities have been established following to the recommendations of FORSTER et al. (2003) for L. vannamei, according to the water temperature and animal size (Table 4). Daily amounts of feed were adjusted according to the feed consumption based on observations (feed leftovers in the fecal collection tubes, animal behavior). Animals were conditioned with the experimental diets for one week, prior start the fecal collection.

Table 4 - Weight and temperature-dependent feeding rates used as reference in the trial.

\begin{tabular}{llll}
\hline \multirow{2}{*}{ Mean body weight $(\mathrm{g})$} & \multicolumn{3}{l}{ Percentage of estimated tank } \\
\cline { 2 - 4 } & $21-24{ }^{\circ} \mathrm{C}$ & $24-28{ }^{\circ} \mathrm{C}$ & $28-32{ }^{\circ} \mathrm{C}$ \\
\hline $1-3$ & 6.0 & 7.0 & 8.0 \\
$3-5$ & 5.0 & 6.0 & 7.0 \\
$5-7$ & 4.5 & 5.5 & 6.5 \\
$7-9$ & 4.0 & 5.0 & 6.0 \\
$9-11$ & 3.5 & 4.5 & 5.5 \\
$11-13$ & 3.0 & 4.0 & 5.0 \\
$13-15$ & 2.5 & 3.5 & 4.5 \\
$15-17$ & 2.5 & 3.0 & 4.0 \\
$17-30$ & 2.0 & 2.5 & 3.0 \\
\hline
\end{tabular}

FORSTER et. al., 2003. 
Feces collection

Fecal matter was collected six times a day, continuously during seven weeks, five times a week, thereafter, the sampling vials were removed and replaced with clean vials. The routine activities are shown in Table 5. The cleaning of the tanks consists in open and rinse the settling chambers with high pressure fresh water, in order to remove the feces, molt and left over feed from the previous night. Also, the inside walls of the tanks were cleaned once a week to remove algae.

The collected fecal matter was poured into an aspirated filtering apparatus, with ashless filter paper (Whatman 541, Whatman International, Maidstone, UK) and rinsed with distilled water. Exuviae and uneaten feed were removed manually during the feces filtration, using a tweezers (Figure 14). The rinsed feces were removed from the filter, placed onto a labeled plastic container and stored at $-15^{\circ} \mathrm{C}$. This collection process was repeated six times a day at 10:00, 11:30,13:00, 14:30, 16:00 and 17:30 h (feces were pooled for each tank over time) in order to avoid leaching and deterioration. The feces collected in the morning (10:00, 11:30 and 13:00) and afternoon (14:30, 16:00 and 17:30) were combined and removed the excess of water, and putted in the freezer after each round of collection, prior of filtering. After 7-weeks of collection, the feces were lyophilized and stored for analysis. 
Table 5 - Routine activities conducted over the 7-week digestibility trial.

\begin{tabular}{|c|c|c|c|c|c|c|c|c|}
\hline Activity & Feeders loading & Tanks cleaning & Feces collection & & Feces filtering & Feces collection & & Feces filtering \\
\hline Hour & $6: 00$ & $8: 30$ & $10: 00$ & $13: 00$ & $13: 15$ & $14: 30$ & $17: 30$ & $17: 45$ \\
\hline
\end{tabular}

Fecal matter was collected six times a day, continuously during seven weeks, five times a week, thereafter, the sampling vials were removed and replaced with clean vials.

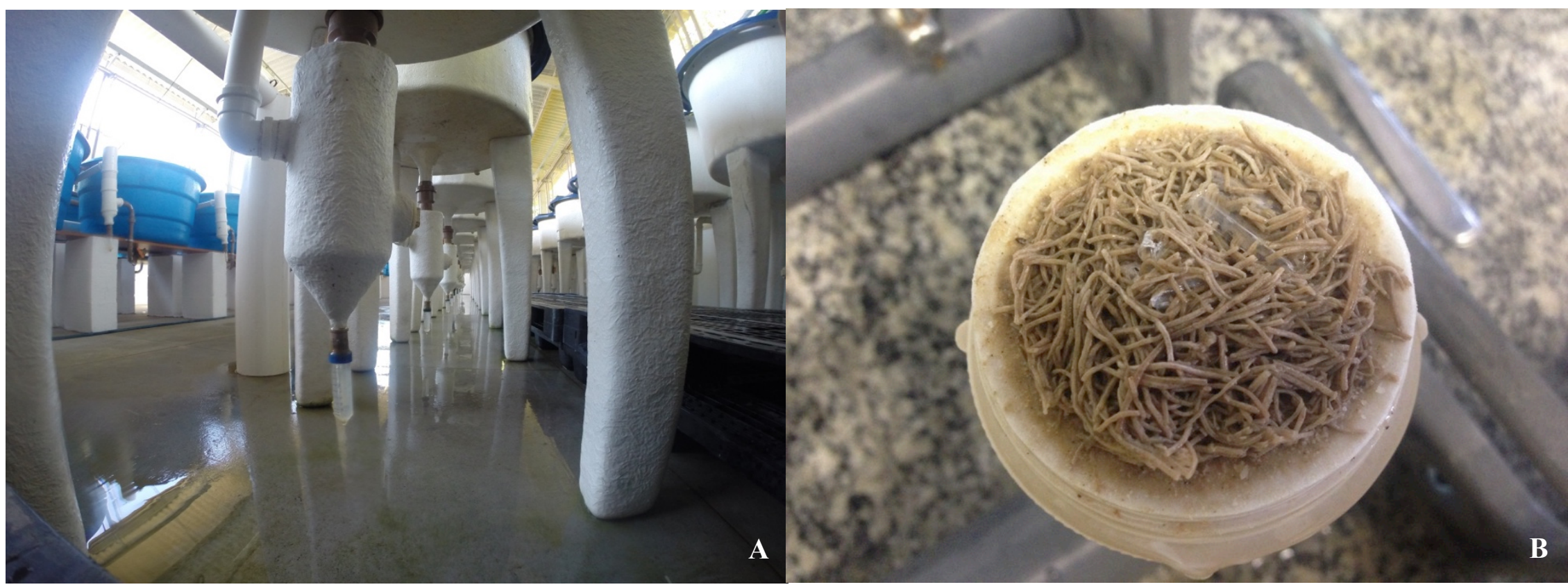

Figure 14 Settling chambers were cleaned once a day with high pressure fresh water, in order to remove the feces, molt and left over feed from the previous night (A). Filtered shrimp feces with exuviae and uneaten feed $(\boldsymbol{B})$. 
Termination of trial and performance analysis

Experimental tanks used in the digestibility study were harvested after 7 weeks (48 days). Only initial and final biometric analyses were carried out in order to reduce stress. Shrimps were culled in ice with water and then enumerated, blotted dry and weighed in group by treatment tank (Figure 15). Feed performance was evaluated by the following biometrics:

Initial body weight (g) = (initial total mass of tank weight / number of shrimp),

Final body weight $(\mathrm{g})=$ (final total mass of tank weight / number of shrimp),

Mean feed offered $(\mathrm{g})=$ (weight of feed offered / number of day $) /$ number of shrimp,

Weight gain $(\%)=($ final shrimp biomass $(\mathrm{g})-$ initial shrimp biomass $(\mathrm{g})) /$ initial shrimp biomass $(\mathrm{g}) * 100$,

Weight gain $(\mathrm{g} /$ week $)=($ final shrimp biomass $(\mathrm{g})-$ initial shrimp biomass $(\mathrm{g})) /$ number of week,

SGR - specific growth rate $=(\ln$ final weight - initial weight $) /$ days $* 100)$,

PER - protein efficiency ratio $=($ final shrimp biomass $(\mathrm{g})-$ initial shrimp biomass $(\mathrm{g})) /$ grams protein fed (dry matter basis),

FCR - feed conversion ratio $=$ total feed offered $(g$, as fed $) /($ final shrimp biomass $(\mathrm{g})-$ initial shrimp biomass (g)),

Survival $(\%)=($ final number of shrimp $/$ initial number of shrimp $) * 100$. 


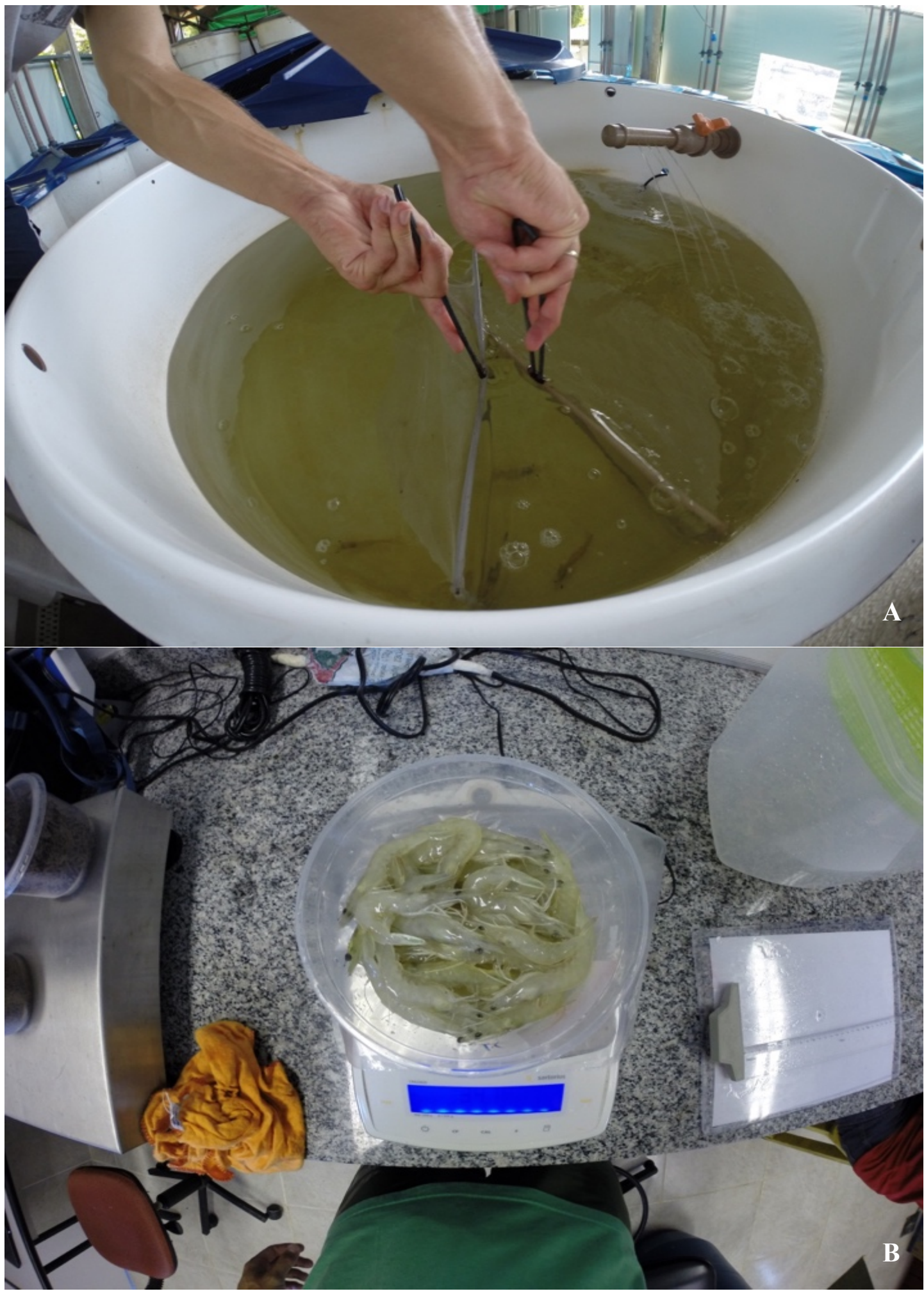

Figure 15 After harvested (A), shrimp were culled in ice and then enumerated, blotted dry and weighed in group by treatment tank $(\boldsymbol{B})$. 


\section{Chemical analysis}

\section{Ingredients}

The ingredients were analyzed by a commercial laboratory (Labtec - Laboratório de Análises Químicas Ltda, Campinas, São Paulo, Brazil), using AOAC (1997) methods for proximate composition. Dry matter was calculated by gravimetric analysis following oven drying at $105^{\circ} \mathrm{C}$ for $24 \mathrm{~h}$. Crude protein $(\mathrm{N} \times 6.25)$ was determined by the Dumas method (AOAC, 1997) on a Leco Truspec (Leco Corporation, St. Joseph, MI, USA). Crude fat was analyzed using hexane extraction (ANKOM XT15, ANKOM Technologic Corp, NY USA), fiber by acid and alkaline digestion (FiberCap 2021/2023, Foss Tecator, Hilleroed, DK), ash by incineration at $550^{\circ} \mathrm{C}$ in a muffle furnace and nitrogen free extract by difference of dry matter minus the sum of protein, fat, fiber and ash. Amino acids were analyzed by HPLC (Shimadzu Prominence HPLC SPD-20A, Shimadzu Analytical, Kyoto, JP) after acid and alkaline digestion by the ionic exchange method (KWANYUEN; BURTON, 2010). Tryptophan was analyzed after alkaline hydroxylation with lithium hydroxide.

\section{Diets and feces}

The proximate composition of the diets and feces was determined according to standards methods (AOAC, 1997). Dry matter was calculated by gravimetric analysis following oven drying at $105^{\circ} \mathrm{C}$ for $24 \mathrm{~h}$. Ash content was determined gravimetrically by combustion in a furnace at $550{ }^{\circ} \mathrm{C}$ for $6 \mathrm{~h}$ (Method 942.05; AOAC, 1997).

Crude protein was analyzed in quadruplicate by determination of total nitrogen $(\mathrm{N} \times 6.25)$ according to the Kjeldahl method using block digestion and steam distillation (Model Kjeltec $^{\mathrm{tm}} 8200$, Foss, DK). Between 0.10 to $0.25 \mathrm{~g}$ of dried sample was weighed and transferred into a digestion flask to which $7.41 \mathrm{~g}$ of catalyst mixture $\left(\mathrm{K}_{2} \mathrm{SO}_{4}: 7 \mathrm{~g}, \mathrm{CuSO}_{4}: 0.21 \mathrm{~g}\right.$, and $\mathrm{TiO}_{2}$ : $0.21 \mathrm{~g}$ ) were added followed by $15 \mathrm{ml}$ of concentrated sulphuric acid. The contents of the flask were digested by heating in a fume chamber for about 1 hour at $420^{\circ} \mathrm{C}$ to allow the nitrogen held in the heterocyclic ring to be released. The content was connected to the nitrogen distillation unit containing $80 \mathrm{ml}$ distilled water and $50 \mathrm{ml}$ of $40 \% \mathrm{v} / \mathrm{w} \mathrm{NaOH}$, which convert ammonium $\left(\mathrm{NH}_{4}+\right)$ into ammonia $\left(\mathrm{NH}_{3}\right)$ thereafter steam distilled into a flask containing $30 \mathrm{ml}$ boric acid 
solution with mixed indicators (bromocresol green and methyl red). Distillation was allowed to proceed until $100-150 \mathrm{ml}$ were collected. The distillate was titrated with $0.1 \mathrm{~N} \mathrm{HCl}$ until color change from blue to dirty green or orange end point, the volume of acid used for neutralization was noted. The percentage of nitrogen was calculated as follows:

$\% \mathrm{~N}=(\mathbf{V}$ sample $-\mathbf{V}$ blank $) * \mathbf{N ~ H C l} * 14,007 * 100 / \mathbf{m}$ (sample), where $\mathbf{V}-$ volume in $\mathrm{ml} ; \mathbf{m}$ mass in g; and $\mathbf{N}$ - normality of $\mathrm{HCl}$.

Crude fat was determined in triplicate by the Soxhlet extraction method using petroleum ether (Model ST255 Soxtec ${ }^{\text {tm }}$, Foss, DK). Feed samples that had been processed, cooked, or extruded often have fat that is bound to proteins, carbohydrates, and/or minerals, making it unavailable for solubilization. For these feeds, the samples were first hydrolysed by boiling with hydrochloric acid (so as to breaks these linkages), and by so doing allowing the fat to be subsequently solvent extracted. Two gram of dried sample was weighed into the thimble, plugged with cotton wool and inserted into the extraction unit. $15 \mathrm{ml}$ of petroleum ether was poured inside each cup (with boiling chips). The pre weighted cups were also inserted into the extraction unit. Extraction was done for $15 \mathrm{~min}$ in "Boiling" position and for 30-45 $\mathrm{min}$ in "Rising" position before the solvent evaporates. The cup was released, dried at $105^{\circ} \mathrm{C}$ for 30 min, and cooled in a desiccator. The fat remaining in the cup was weighed and the percentage fat calculated.

The chromic oxide contents of diets and feces was determined using a spectrophotometric method and 1,5-diphenylcarbazide for the determination of chromium as adjusted by BREMERNETO et al. (2005). The sample (100mg, duplicate) was classically digested with a nitric/perchloric acid mixture leading to the oxidation of chromium (III) to chromium (VI), and an aliquot of the diluted extract then used for reaction with 1,5-diphenylcarbazide. Absorbance was measured at $550 \mathrm{~nm}$, using $1 \mathrm{~cm}$ path length optical cuvettes. Potassium dichromate was used as a standard substance to obtain the standard curve ranging from 0.25 to $2.5 \mathrm{~m} / \mathrm{mL}$ of $\mathrm{Cr}_{2} \mathrm{O}_{3}$.

The internal marker acid-insoluble ash (AIA) within shrimp feeds and feces was analyzed following the method proposed by ATKINSON et al. (1984) with slight modification. Briefly, sample was weighed $(2.0,3.0,10.0$ and $15.0 \mathrm{~g}$ for the diets and 0.5 to $2.0 \mathrm{~g}$ for the feces) in 
triplicate into a pre weighed porcelain crucible and placed in a muffle furnace. Temperature was gradually increased to $600^{\circ} \mathrm{C}$ and the sample then ashed for $6 \mathrm{~h}$. The sample was then transferred to a desiccator, cooled and weighed, discounting the crucible weight. The resulting ash was then boiled in $25 \mathrm{~mL} \mathrm{HCl} 2 \mathrm{~N}$ for 5 minutes, filtered with the aid of a vacuum pump through ashless filter paper (Whatman 44) and residue then washed with hot water. The filter paper and residue were then placed in porcelain crucible and ashed for $6 \mathrm{~h}$ at $600{ }^{\circ} \mathrm{C}$. The resulting AIA was transferred to desiccator, cooled and weighed, discounting the crucible weight.

\section{Apparent digestibility coefficients}

Apparent digestibility coefficients for dry matter and crude protein of the diet was calculated using the following equations (CHO et al., 1985):

ADC Dry matter $(\%)=100-[100(\%$ marker in feed $/ \%$ marker in feces $)$; where markers $\left(\mathrm{Cr}_{2} \mathrm{O}_{3}\right.$ and AIA) are expressed as \% (dry matter basis). ADC Crude protein (\%) $=100-$ [100 (\% marker in feed / \% marker in feces) x (\% CP in feces / \% CP in feed); where crude protein $(\mathrm{CP})$ and markers ( $\mathrm{Cr}$ and $\mathrm{AIA})$ are expressed as \% (dry matter basis).

\section{Water quality}

Temperature, salinity and dissolved oxygen (DO) were monitored daily using a YSI $85^{\circledR}$ meter (YSI Inc., Yellow Springs, $\mathrm{OH}$ ). Ammonia-nitrogen, $\mathrm{NO}_{2}-\mathrm{N}$, and $\mathrm{pH}$ were monitored weekly. Samples for analyzes of ammonia-nitrogen, $\mathrm{NO}_{2}-\mathrm{N}$, and $\mathrm{pH}$ were collected at the exit of the experimental tanks and analyzed using a commercial colorimetric kit for saltwater (Alfakit, Florianópolis, SC, Brazil).

\section{Statistical analysis}

Data were analyzed as a design using the JMP ${ }^{\circledR}$ version 12.0.1 (SAS Institute Inc., Cary, NC, USA). Significant differences in the means between dietary treatments were evaluated by one-way ANOVA and Tukey's multiple range tests., and with Student's t-test where there were only two treatments. Probabilities were considered significant at $P<0.05$. 


\subsection{Results}

Water quality

The water quality parameters observed over the 7-week study are shown in Table 6.

Table 6 - Water quality over the 7-week feeding trial.

\begin{tabular}{lllllll}
\hline $\begin{array}{l}\text { Temperature } \\
\left({ }^{\circ} \mathrm{C}\right)\end{array}$ & $\begin{array}{l}\text { Salinity } \\
(\mathrm{ppt})\end{array}$ & $\begin{array}{l}\text { Dissolved } \\
\mathrm{O}_{2}(\mathrm{mg} / \mathrm{L})\end{array}$ & $\begin{array}{l}\mathrm{NH}_{3}-\mathrm{N} \\
(\mathrm{mg} / \mathrm{L})\end{array}$ & $\mathrm{NO}_{2}-\mathrm{N}(\mathrm{mg} / \mathrm{L})$ & $\mathrm{pH}$ & $\begin{array}{l}\text { Alkalinity } \\
\left(\mathrm{CaCO}_{3} \mathrm{mg} / \mathrm{L}\right)\end{array}$ \\
\hline $30.1(0.8)$ & $34.2(2.5)$ & $4.6(0.5)$ & $\begin{array}{l}0.08 \\
(0.08)\end{array}$ & $0.02(0.01)$ & $8.0(0.0)$ & $114.0(20.7)$ \\
\hline
\end{tabular}

Values expressed as mean (s.d.).

\section{Feed offer}

The total feed offered $(\mathrm{g})$ during the 7 weeks of the feeding trial is presented in Figure 16.

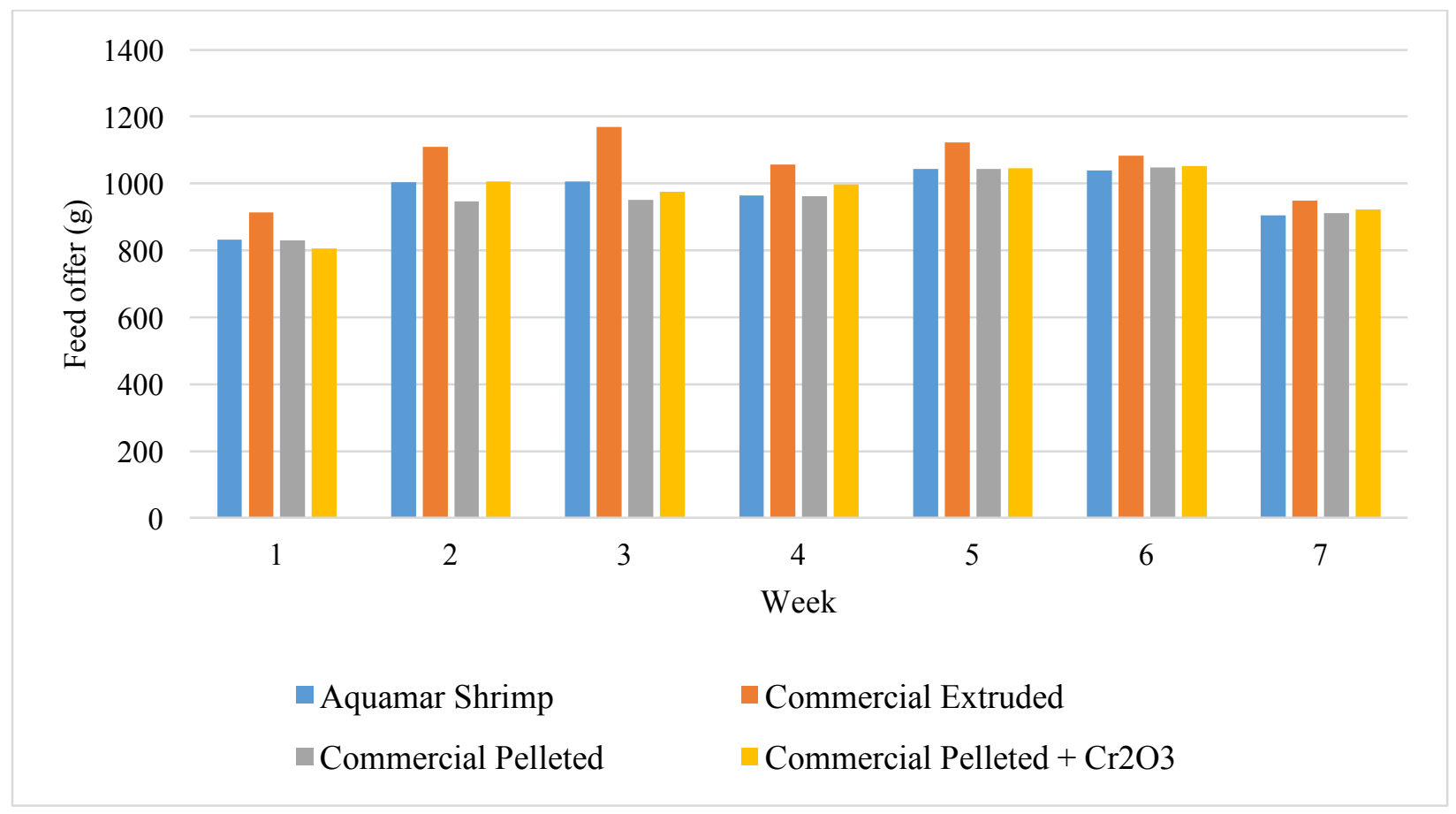

Figure 14 Feed quantity offered during the 7 weeks (48 days) of the trial. Each column represents the sum of seven replicates (tanks) from each treatment (feed). The week \#7 represents the sum of feed weight from six days. 


\section{Animal performance}

Shrimp performance over the 7-week digestibility trial are summarized in Table 7. The Commercial Extruded diet produced significantly $(P<0.05)$ greater responses than all other diets for the measured growth parameters (final body weight $(\mathrm{g})$, weight gain (\%), weight gain (g/week), and specific growth rate (SGR)). Protein efficiency ratio of diet Commercial Extruded $(1.2 \pm 0.1)$ was significantly higher comparing with the other, except for diet Commercial Pelleted $+\mathrm{Cr}_{2} \mathrm{O}_{3}(1.1 \pm 0.1)$. Diet Aquamar Shrimp had the highest FCR value (3.0 \pm 0.3$)$, being statistically equal with diet Commercial Pelleted $(2.7 \pm 0.3)$. The adjusted FCR (considering the mortality) was lower compared with the FCR. Survival was reasonably good (82.8-88.1\%) for all dietary treatments and was not significantly different among treatments $(P>0.05)$. No difference $(P>0.05)$ in performance was observed when $\mathrm{Cr}_{2} \mathrm{O}_{3}$ was added to the Commercial Pelleted diet. On the other hand, the process of extrusion influence positively in all performance parameters measured in this study. 
Table 7 - Performance of Litopeneus vannamei fed experimental and commercial diets for 7 weeks.

\begin{tabular}{|c|c|c|c|c|c|c|c|c|c|}
\hline Diet & $\begin{array}{l}\text { Initial } \\
\text { body } \\
\text { weight }(\mathrm{g})\end{array}$ & $\begin{array}{l}\text { Final body } \\
\text { weight }(\mathrm{g})\end{array}$ & $\begin{array}{l}\text { Mean feed } \\
\text { offered } \\
\left(\mathrm{g} \text { shrimp }^{-1}\right. \\
\left.\text { day }^{-1}\right)\end{array}$ & $\begin{array}{l}\text { Weight gain } \\
(\%)\end{array}$ & $\begin{array}{l}\text { Weight gain } \\
\text { (g/week) }\end{array}$ & SGR & PER & FCR & $\begin{array}{l}\text { Survival } \\
(\%)\end{array}$ \\
\hline Aquamar Shrimp $^{1}$ & $6.3(0.5)$ & $14.1(0.7)^{b}$ & $0.33(0.01)^{\mathrm{b}}$ & $125.7(8.9)^{\mathrm{b}}$ & $1.1(0.1)^{\mathrm{c}}$ & $1.7(0.1)^{b}$ & $1.0(0.1)^{b}$ & $3.0(0.3)^{\mathrm{a}}$ & $82.8(4.3)$ \\
\hline Commercial Extruded $^{2}$ & $6.1(0.2)$ & $15.5(0.5)^{\mathrm{a}}$ & $0.36(0.01)^{\mathrm{a}}$ & $152.3(8.9)^{\mathrm{a}}$ & $1.3(0.1)^{\mathrm{a}}$ & $1.9(0.1)^{\mathrm{a}}$ & $1.2(0.1)^{\mathrm{a}}$ & $2.4(0.3)^{\mathrm{b}}$ & $88.1(4.7)$ \\
\hline Commercial Pelleted $^{3}$ & $6.2(0.4)$ & $14.5(0.8)^{\mathrm{b}}$ & $0.32(0.01)^{\mathrm{b}}$ & $133.2(11.3)^{\mathrm{b}}$ & $1.2(0.1)^{\mathrm{bc}}$ & $1.7(0.1)^{\mathrm{b}}$ & $0.9(0.1)^{\mathrm{b}}$ & $2.7(0.3)^{\mathrm{ab}}$ & $84.0(5.0)$ \\
\hline $\begin{array}{l}\text { Commercial Pelleted + } \\
\mathrm{Cr}^{2} \mathrm{O}^{4}\end{array}$ & $6.2(0.2)$ & $14.8(0.4)^{\mathrm{b}}$ & $0.33(0.00)^{\mathrm{b}}$ & $137.5(8.4)^{\mathrm{b}}$ & $1.2(0.0)^{\mathrm{b}}$ & $1.8(0.1)^{\mathrm{b}}$ & $1.1(0.1)^{\mathrm{ab}}$ & $2.5(0.2)^{\mathrm{b}}$ & $86.7(4.8)$ \\
\hline
\end{tabular}

${ }^{1}$ Shrimp experimental diet, Aquamar Shrimp

${ }^{2}$ Shrimp commercial extruded diet.

${ }^{3}$ Shrimp in-house prepared dry pellet.

${ }^{4}$ Shrimp in-house prepared dry pellet adding $\mathrm{Cr}_{2} \mathrm{O}_{3}$.

Mean feed offered $\left(\mathrm{g} \mathrm{shrimp}^{-1}\right.$ day $\left.^{-1}\right)=$ (weight of feed offered / number of day) $/$ number of shrimp.

Weight gain $(\%)=($ final weight - initial weight $) /$ initial weight $* 100$.

Weight gain $\left(\mathrm{g}\right.$ shrimp ${ }^{-1}$ week $\left.{ }^{-1}\right)=($ final shrimp biomass $(\mathrm{g})-$ initial shrimp biomass $(\mathrm{g})) /$ number of week.

SGR - specific growth rate $=(\ln$ final weight - initial weight $) /$ days $* 100)$.

PER - protein efficiency ratio $=($ final shrimp biomass $(\mathrm{g})-$ initial shrimp biomass $(\mathrm{g})) /$ grams protein fed (dry matter basis $)$.

FCR - feed conversion ratio $=$ total feed offered $(\mathrm{g}$, as fed) / (final shrimp biomass $(\mathrm{g})$ - initial shrimp biomass $(\mathrm{g})$ ). 


\section{Marker analysis}

The standard curve for the chromic oxide analysis is presented in Figure 17 . The $\mathrm{R}^{2}$ of 0.99968 obtained in the standard curve it is in the range suggested by the spectrophotometric method of 1,5-diphenylcarbazide for the determination of chromium adjusted by BREMERNETO et al. (2005). The generated equation $(y=0.4287 x+0.0010)$ was used in the prediction of $\mathrm{Cr}_{2} \mathrm{O}_{3}$, expressed in percentage. A low coefficient of variation $(<5 \%)$ was obtained in all the samples.

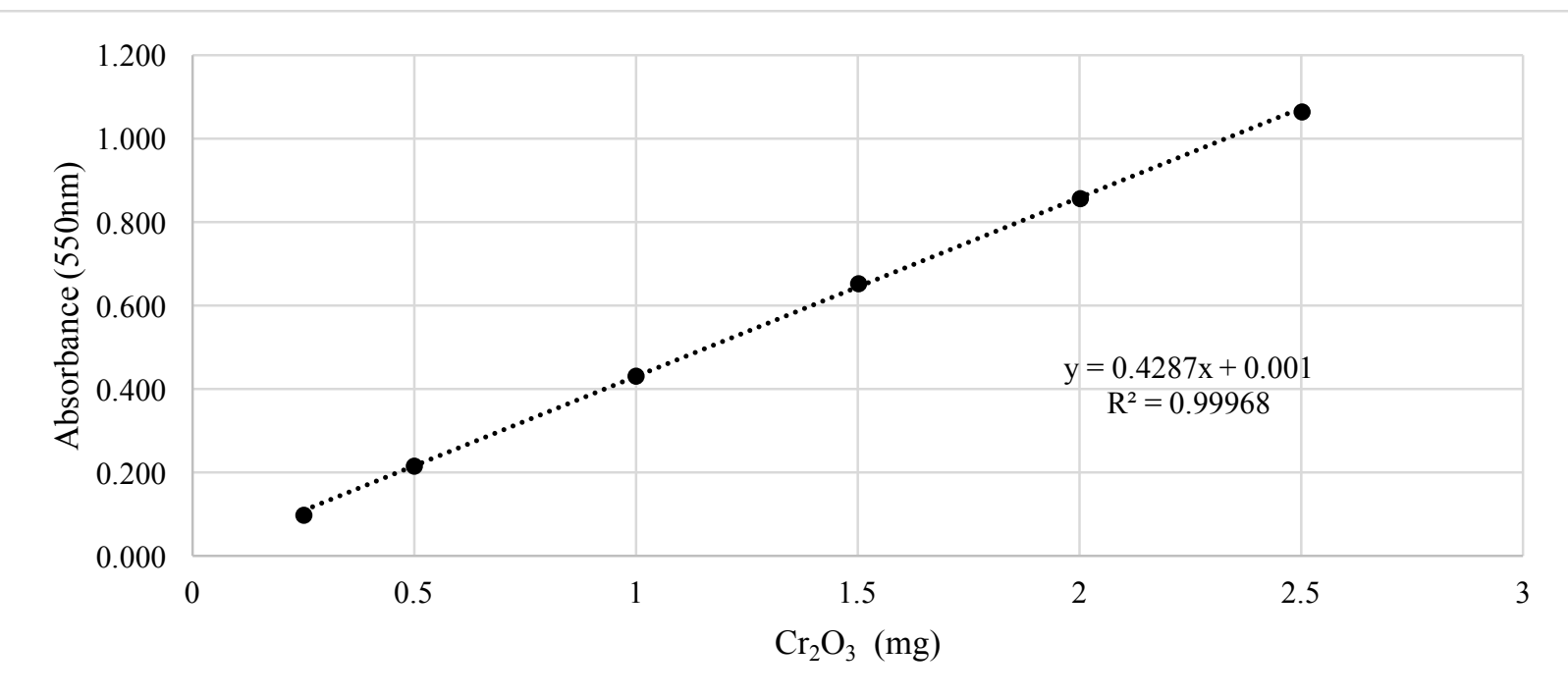

Figure 17 Potassium dichromate was used as a standard substance to obtain the standard curve ranging from 0.25 to $2.5 \mathrm{mg} / \mathrm{mL}$ of $\mathrm{Cr}_{2} \mathrm{O}_{3}$.

The influence of sample quantity in the determination of the internal marker acid insoluble acid (AIA) is presented in Table 8 and Figure 18. It was observed that feeds samples with low percentage of AIA (less than 1\%) had a high (>5\%) coefficient of variation (CV) when analyzed with amounts less than $15 \mathrm{~g}$. The CV gets lower as the amount of sample increase, as shown in Figure 18. For the diets that have $\mathrm{Cr}_{2} \mathrm{O}_{3}$ in their composition (Aquamar Shrimp and Potimar Pelleted $\mathrm{Cr}_{2} \mathrm{O}_{3}$ ), the percentage of AIA was greater, concluding that the $\mathrm{Cr}_{2} \mathrm{O}_{3}$ is part of the AIA. 
Table 8 - Influence of sample quantity (g) in the standard deviation (SD) and coefficient of variation (CV) of internal marker (acid insoluble ash - AIA) in two commercial shrimp feeds.

\begin{tabular}{lllll}
\hline Feed & Quantity $(\mathrm{g})$ & AIA $(\%)$ & SD & CV $(\%)$ \\
\hline Commercial pelleted & 2.0 & 0.10 & 0.046 & 51.7 \\
& 3.0 & 0.17 & 0.027 & 16.9 \\
& 10.0 & 0.16 & 0.013 & 8.9 \\
& 15.0 & 0.18 & 0.003 & 1.5 \\
Commercial extruded & & & & \\
& 2.0 & & & \\
& 3.0 & 0.10 & 0.081 & 87.3 \\
& 10.0 & 0.12 & 0.063 & 58.6 \\
& 15.0 & 0.16 & 0.028 & 19.0 \\
\hline
\end{tabular}

Values are the mean of three replicates per feed sample.

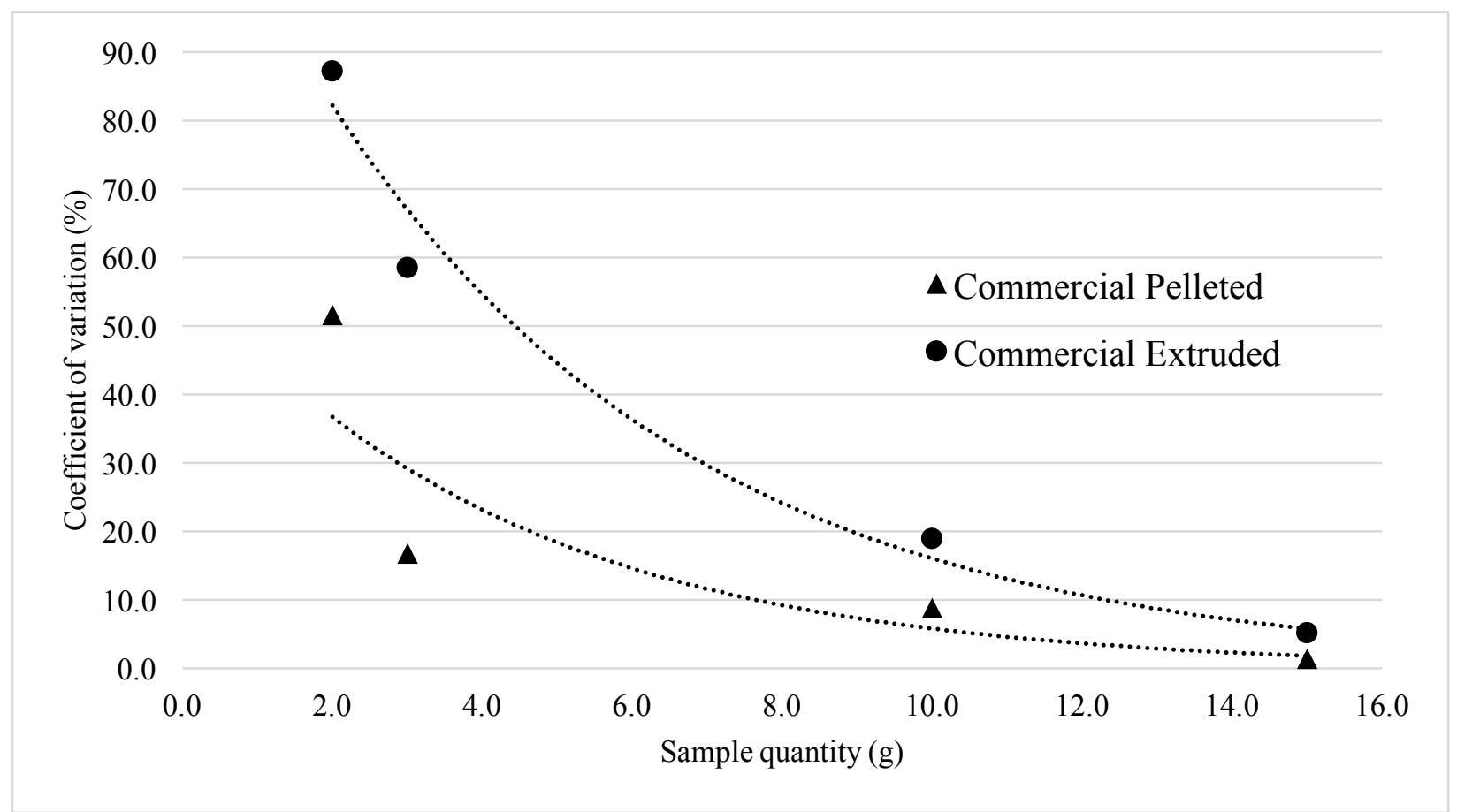

Figure 18 Influence of feed sample quantity ( $g$ ) in the coefficient of variation (CV) of internal marker (acid insoluble ash - AIA) in two commercial shrimp feeds. 
The results of the AIA content in feeds and feces is shown in Table 9. The CV for feed samples (three replicates) were below 5\%. For the feces samples, the CV of AIA content between the seven tanks ranged from 8.0 to $18.0 \%$. The $\%$ of AIA in feces was proportional with the $\%$ in the feed.

Table 9 - Mean (s.d.) value and coefficient of variation (CV) of internal marker (acid insoluble ash - AIA) in feed and feces (\%, dry matter).

\begin{tabular}{lllll}
\hline \multirow{2}{*}{ Diet } & Feed & \multicolumn{3}{l}{ Feces } \\
\cline { 2 - 5 } & AIA $(\%)$ & CV $(\%)$ & AIA (\%) & CV (\%) \\
\hline Aquamar Shrimp & $1.92(0.06)$ & 3.12 & $4.18(0.45)$ & 11.00 \\
Commercial Extruded & $0.18(0.01)$ & 5.00 & $0.68(0.07)$ & 10.00 \\
Commercial Pelleted & $0.18(0.00)$ & 1.48 & $0.68(0.05)$ & 8.00 \\
Commercial Pelleted $+\mathrm{Cr}_{2} \mathrm{O}_{3}$ & $0.61(0.02)$ & 3.88 & $1.44(0.26)$ & 18.00 \\
\hline
\end{tabular}

Feed AIA content value is the mean of three replicates, feces AIA content value is the mean of seven replicates (tank).

\section{Apparent digestibility coefficients}

The apparent digestibility coefficients (ADC) for dry matter and crude protein by shrimp fed with the experimental and commercial diets is shown in Table 10.

Table 10 - Apparent digestibility coefficients (ADC) for dry matter (ADDM) and crude protein (ADCP) using $\mathrm{Cr}_{2} \mathrm{O}_{3}$ and AIA as inert marker, for shrimp tested over 7-weeks.

\begin{tabular}{lllll}
\hline \multirow{2}{*}{ Diet } & $\mathrm{Cr}_{2} \mathrm{O}_{3}$ & \multicolumn{3}{l}{ AIA } \\
\cline { 2 - 5 } & $\mathrm{ADDM}(\%)$ & ADCP (\%) & ADDM (\%) & ADCP(\%) \\
\hline Aquamar Shrimp & $57.3(4.9)^{\mathrm{a}}$ & $67.4(3.8)^{\mathrm{a}}$ & $53.7(5.1)^{\mathrm{b}}$ & $64.6(4.3)^{\mathrm{c}}$ \\
Commercial Pelleted $+\mathrm{Cr}_{2} \mathrm{O}_{3}$ & $65.5(1.7)^{\mathrm{b}}$ & $79.3(0.8)^{\mathrm{b}}$ & $54.8(8.5)^{\mathrm{b}}$ & $73.0(4.9)^{\mathrm{b}}$ \\
Commercial Pelleted & - & - & $72.3(2.4)^{\mathrm{a}}$ & $82.8(1.8)^{\mathrm{a}}$ \\
Commercial Extruded & - & - & $73.1(2.5)^{\mathrm{a}}$ & $83.3(1.5)^{\mathrm{a}}$ \\
\hline
\end{tabular}

Values expressed as mean (s.d.) of seven replicates (tanks). Different superscript letters within the same column indicate significant difference $(P<0.05)$ for ADC values.

The potential influence of the quantity of AIA (feed) in the ADC of dry matter (ADDM) and crude protein (ADCP) in shown in Figure 19. It was observed a decreasing tendency in the $\mathrm{ADC}$, as the AIA content increases in the diet. 


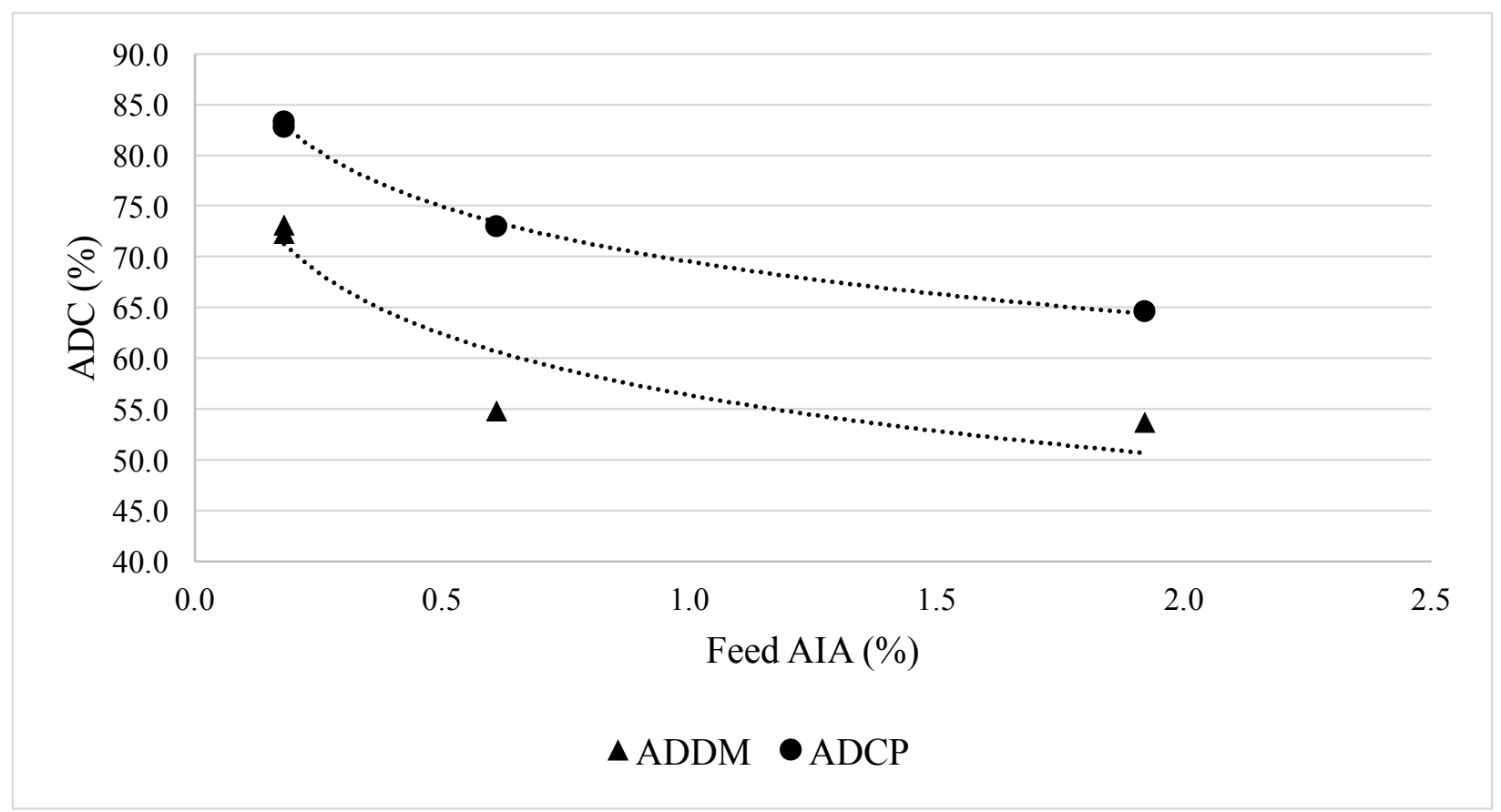

Figure 19 Potential influence of the quantity of AIA (feed) in the ADC of dry matter (ADDM) and crude protein $(A D C P)$.

The influence of external $\left(\mathrm{Cr}_{2} \mathrm{O}_{3}\right)$ and internal (AIA) markers on the apparent digestibility coefficient (ADC) of dry matter (DM) is shown in Figure 20. There was no significant difference between both markers, $\mathrm{Cr}_{2} \mathrm{O}_{3}$ and AIA for the diet Aquamar Shrimp. Difference was observed in diet Commercial Pelleted $+\mathrm{Cr}_{2} \mathrm{O}_{3}$, that had lower ADC value (54.8\%) using AIA, compared with the external marker $\mathrm{Cr}_{2} \mathrm{O}_{3}(65.5 \%)$.

The influence of marker on the ADC for crude protein (CP) is presented in Figure 21. For the ADC of $\mathrm{CP}$, there was observed significantly difference between $\mathrm{Cr}_{2} \mathrm{O}_{3}$ and AIA markers only for the diet Commercial Pelleted $+\mathrm{Cr}_{2} \mathrm{O}_{3}$. The crude protein ADC results for the diet Aquamar Shrimp were 67.4 and 64.6\%, using $\mathrm{Cr}_{2} \mathrm{O}_{3}$ and AIA, respectively, and was not significant different.

The results of $\mathrm{ADC}$ of dry matter and crude protein for the commercial diets using AIA as marker is presented in Figure 22. Comparing the feed processing (extruded vs. pelleted), there was no difference in the results of $\mathrm{ADC}$ of $\mathrm{DM}$ and $\mathrm{CP}$, for both Commercial Pelleted and Commercial Extruded diets. 


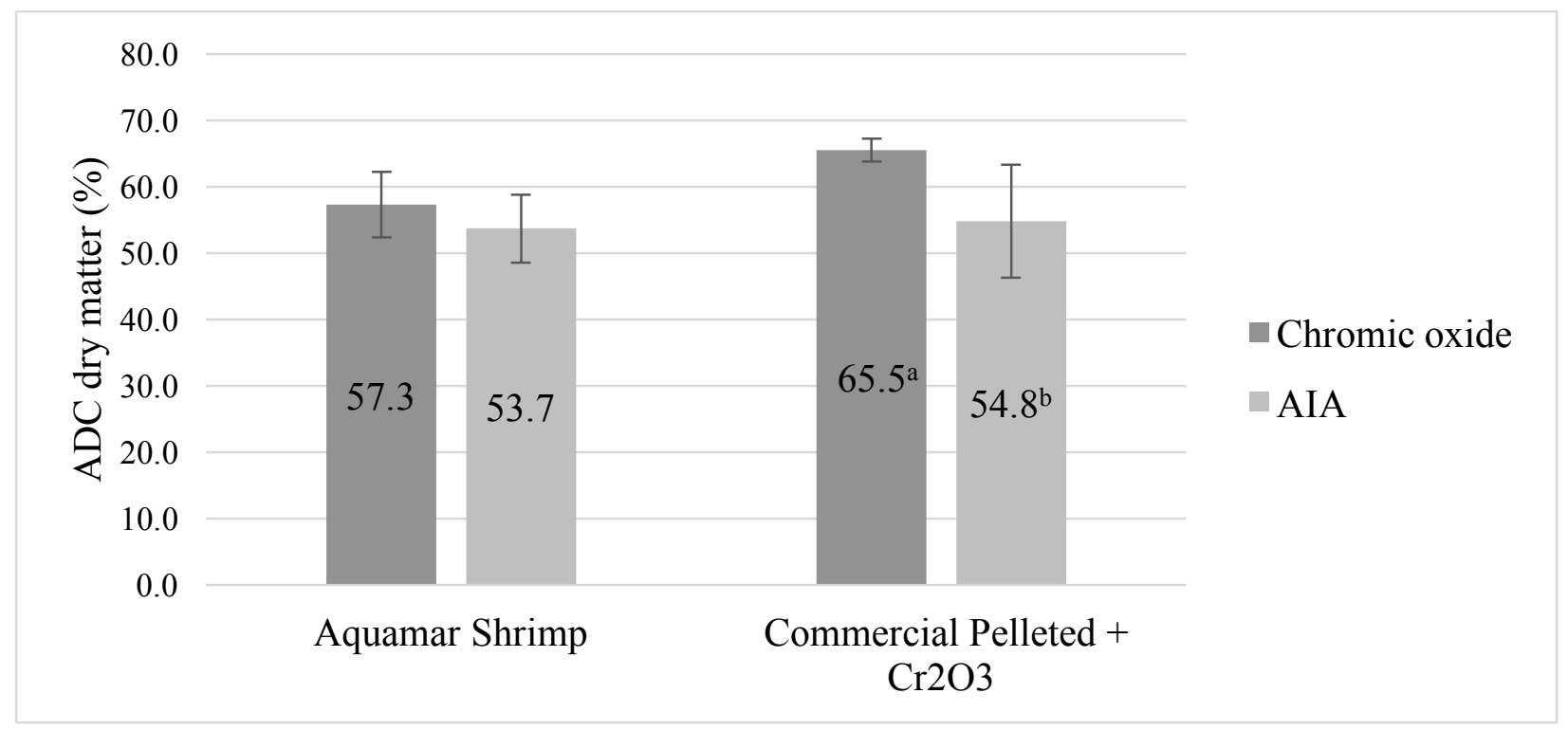

Figure 20 Influence of inert marker $\left(\mathrm{Cr}_{2} \mathrm{O}_{3}\right.$ and AIA) on the apparent digestibility coefficient (ADC) of dry matter. Each column represents the mean (s.d. as error bar) of seven tanks. Different superscript letters indicate significant difference $(\mathrm{P}<0.05)$ within the same diet. 


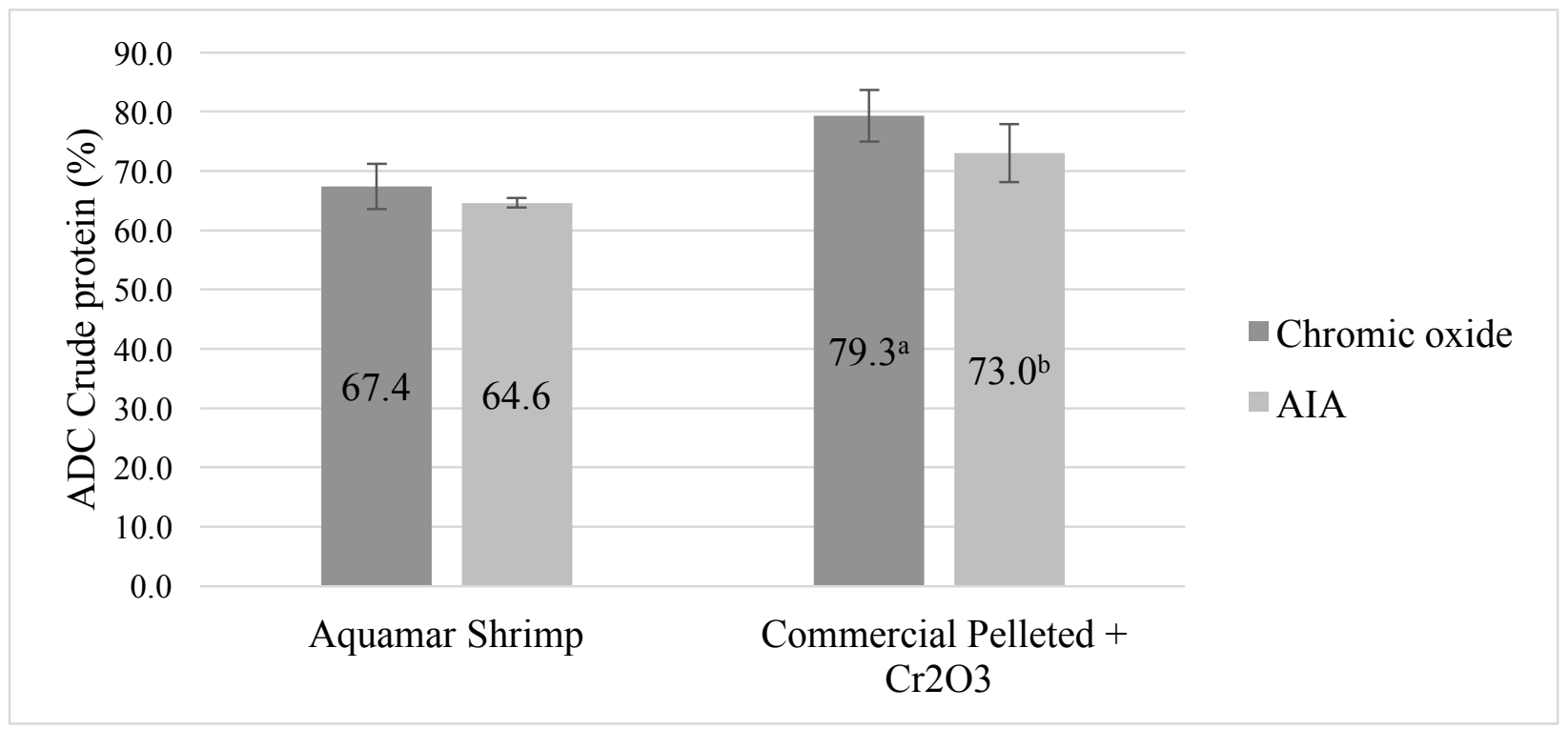

Figure 21 Influence of inert marker $\left(\mathrm{Cr}_{2} \mathrm{O}_{3}\right.$ and AIA) on the apparent digestibility coefficient (ADC) of crude protein. Each column represents the mean (s.d. as error bar) of seven tanks. Different superscript letters indicate significant difference $(\mathrm{P}<0.05)$ within the same diet.

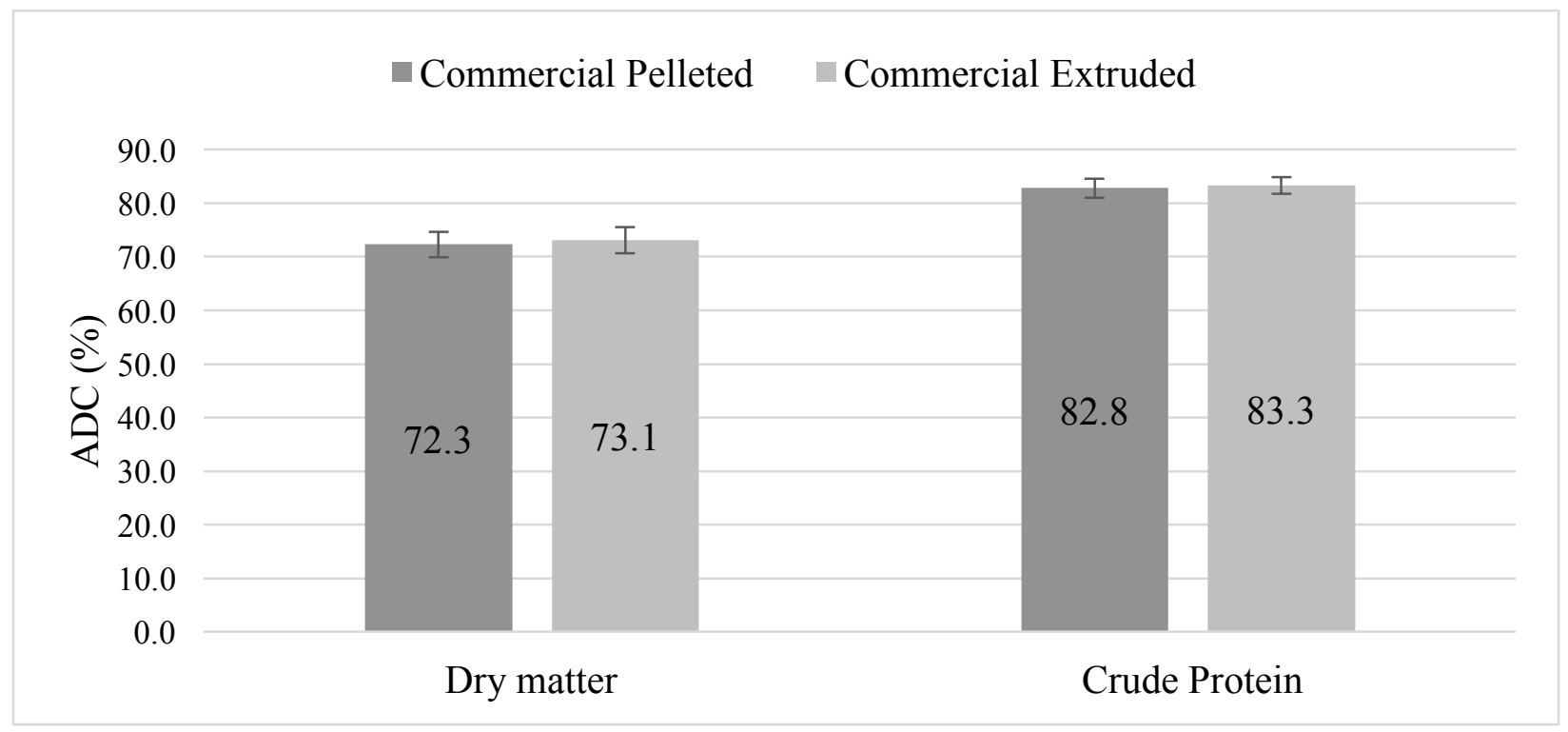

Figure 22 Influence of feed processing on the apparent digestibility coefficient of dry matter and crude protein, using the marker AIA. Each column represents the mean (s.d. as error bar) of seven tanks. 


\subsection{Discussion}

Water quality values observed during this experiment within the recommended limits for shrimp (VAN WYK et al., 1999). Although dissolved oxygen levels varied between experimental tanks, values were consistently greater than $4.0 \mathrm{mg} / \mathrm{L}$ and exceeded the minimum requirements of $3.0 \mathrm{mg} / \mathrm{L}$ for shrimp culture (SEIDMAN; LAWRENCE, 1986). Temperature ranged between 29 and $30^{\circ} \mathrm{C}$, which is considered optimum for promoting rapid growth (WYBAN et al., 1995). The $\mathrm{pH}$ also remained in the range considered appropriate for good performance of penaeid shrimp (7.0-9.0) (VAN WYK et al., 1999). According to VAN WYK et al. (1999), an alkalinity $\geq 100 \mathrm{mg} / \mathrm{L} \mathrm{CaCO}_{3}$ is recommended for the culture of penaeids, which it is under the average obtained in this study $(114.0 \mathrm{mg} / \mathrm{L})$.

The best overall shrimp growth performance was observed in animals fed with the Commercial Extruded feed, with a final shrimp body weight $(15.5 \pm 0.5 \mathrm{~g})$, weight gain $(152 \pm$ $8.9 \%)$, and weight gain per week $(1.3 \pm 0.1 \mathrm{~g})$ significantly higher $(P<0.05)$ than the other treatments. Although the average FCR for the feed Commercial Extruded was better (2.4 \pm 0.3$)$ it was still high for the industry standards. NUNES; ROCHA (2015) reported that the FCR of pond raised shrimps at farms located in the northeast of Brazil ranged from 1.0 to 1.5. Moreover, an over-feeding of shrimp using the belt-feeders to ensure maximum fecal excretion and collection, may have increased the FCR. Direct comparison between all the treatments may not be possible because of the differences in dietary proximate composition (mainly crude protein and lipid content) between diets, and a comparison between both commercial pelleted feeds showed no significant difference between them in terms of performance results, suggesting that chromic oxide did not interfere with these parameters.

A major consideration in the choice of an inert marker is the ease and accuracy of its analysis. Acid insoluble ash (AIA) is an inexpensive marker for determining digestibility of crustacean diets and can be quantified using minimum equipment and technical expertise. The endogenous AIA content of the commercial feeds used in the present study ranged from 0.18 to $0.60 \%$. THONNEY et al. (1985) recommended that the dietary AIA content should exceed $0.75 \%$ on a dry matter basis in order to get accurate measurements and that appropriate diets should contain certain ingredients that are high in AIA. Precise results may be obtained without 
addition of exogenous sources and with low quantity of samples $(2.0 \mathrm{~g})$. In the present study, in order to achieve a low coefficient of variation (less than 5.0\%) in the AIA analysis, it was necessary to use high feed $(15.0 \mathrm{~g})$ and feces $(2.0 \mathrm{~g})$ amount samples. Collecting sufficient feces is a challenge in digestibility studies with shrimp, and the accumulation of a reasonable quantity of dry sample from each replicate (tank) may be a major limitation factor. However, we were successful during the feces collection in this trial, accumulating at least $15.0 \mathrm{~g}$ of dry feces samples from each tank. Moreover, SMITH; TABRETT (2004) suggested that improvement in the homogeneity of the feed could reduce the $\mathrm{CV}$ of the measured concentrations of nutrients and marker in the feces.

Unrealistic digestibility values with the use of AIA as marker has been assigned to analytical imprecision due to a low dietary and fecal AIA content that introduced a large margin of error to the calculation (VAN KEULEN; YOUNG, 1977; JONES; DE SILVA, 1998). There is some controversy in the literature about whether AIA can be validly used as a marker as some of it appears to be absorbed during digestion (LEAVITT, 1985; JONES; DE SILVA, 1998). JONES; DE SILVA (1998), working with the Australian freshwater crayfish Cherax destructor compared estimates of ADC obtained with chromic oxide to the estimates obtained with a range of internal markers: ash, crude fiber, AIA and hydrolysis resistant organic matter. Based on the ease and speed of determination, they concluded that dietary ash could be used as a digestibility marker where more sophisticated analytical facilities are not available. DEERING et al. (1996) obtained similar estimates of ADC using chromic oxide, ytterbium acetate and AIA, though the coefficient of variation of the estimate with AIA was about twice as large as with the other markers. As the ash techniques are gravimetric, a greater mass of feces would need to be collected than with chromic oxide, particularly if the ash content of the diets is low.

In several studies the AIA content of feeds has been increased by addition of exogenous sources of AIA. Thus, AIA would be also classified as an external marker, but the original objective of this study was to transfer the technique to the field using commercial feeds without the addition of any external source or marker. Although the addition of exogenous AIA sources will improve precision of measurement (THONNEY, 1981), MCCARTHY et al. (1974) found that when Celite ${ }^{\circledR}$ was added to pig diets, the AIA method underestimated digestibility of nitrogen and energy in comparison to total collection, while comparable values were found 
between methods when Celite ${ }^{\circledR}$ was excluded. They suggested that some Celite ${ }^{\circledR}$ may be partly lost during feeding. A similar trend with addition of bentonite was reported in studies with abalone (SALES; BRITZ, 2001). TACON; RODRIGUES (1984) found that precision decreased when dietary AIA concentration was increased to $2.0 \%$ with acid-washed sand in trout, while the opposite (increased precision) was found with the addition of a product of fine diatoms to pig diets (JONGBLOED et al., 1991) and Celite $^{\circledR}$ to broiler diets (SCOTT; BALDAJI, 1997). Although SCHANG et al. (1983) stated that it is reasonable to assume that the flow of AIA through the alimentary tract of poultry reflects the passage of undigested feed residues, WETHERBEE; GRUBER (1993) reported differential intestinal passage rates for AIA and feed in the lemon shark (Negaprion brevirostris).

The main concern about the use of chromic oxide as a digestibility marker in crustacean studies has been its apparent differential rate of passage through the digestive tract, as observed by color changes in the feces (FORSTER; GABBOTT, 1971; BORDNER et al., 1983; LEAVITT, 1985; JONES; DE SILVA, 1997). In this study, we did not measure the rate of passage, but color changes in the feces was noticed during the feces collection. In the present study, the estimated ADC results using AIA as marker were lower for both ADDM and ADCP, when compared with values obtained using $\mathrm{Cr}_{2} \mathrm{O}_{3}$ as marker. DIVAKARAN et al. (2000) evaluating ADC of soybean meal by L. vanammei, at two different levels of inclusion pf soybean meal and chromic oxide (0.5 and $1.0 \%)$, suggested that the level of soybean meal influenced the rate of passage of the chromic oxide through the digestive tract, and the interaction with each other may be affect the calculated digestibility coefficients. DIVAKARAN (2005) suggested the $\sim 1 \%$ free chromium, as chromium salts, in chromic oxide could be absorbed by shrimp, therefore it could be possible the low ADC of the Commercial Pelleted $+\mathrm{Cr}_{2} \mathrm{O}_{3}$ reported in this study may have been caused by chromium affecting the gut either as an irritant or as a "mild" toxicant. LEAVITT (1985) considered that it was not valid to use chromic oxide as it had a differential passage, relative to organic matter, in the gut of the American lobster. BROWN et al. (1986) also reported that adult red crayfish egested chromium more rapidly than the remaining undigested portion of the diet and, in addition, reported that crayfish ingested a lower proportion of chromic oxide than was in the feed, suggesting selective rejection of the chromic oxide. SHIAU; LIANG (1995) found that different molecular species of the oxides of chromium influenced carbohydrate 
utilization in tilapia, suggesting absorption and physiological activity of the chromium. The purity of chromic oxide can vary between 98\% and 99.99\% (ALDRICH, 2003). Lower purity chromic oxide, when included at $0.5 \%$ or $1.0 \%$ in a diet can add to the soluble chromium content of the diet, or contain other contaminants, that could have a physiological effect (SMITH; TABRETT, 2004). Consequently, consideration may need to be given to the purity of the material used. In this study, it was used the inclusion rate of chromic oxide to lower concentration $(0.5 \%)$ than generally reported, in order to minimize any physiological effect of the marker or entrained contaminants.

Unlike fish, stripping or dissection are still not feasible methods of collecting fecal material from crustaceans. Loss of nutrients from the feces, without the loss of markers, during the period between defecation and collection may cause an overestimation of digestibility. BURFORD; WILLIAMS (2001) measured the loss of $\mathrm{N}$ from the feces of P. monodon and found that $4.9 \mathrm{mg}$ of fecal $\mathrm{N}$ (dry matter basis) was lost through leaching in $4.5 \mathrm{~h}$. SMITH; TABRETT (2004) have found a difference of $8.4 \mathrm{mg}$ of total $\mathrm{N}$ between feces that were collected on an hourly basis over $6 \mathrm{~h}$ and then pooled, and those that were collected on a six-hourly basis, from the feces of P. monodon. ALLAN et al. (1999) found an increase in ADC with increased immersion time after $12 \mathrm{~h}$ when measuring the digestibility of silver perch Bidyanus bidyanus feeds using a modified Guelph settling system. When working with shrimp, it appears that collection of feces at intervals of $<1 \mathrm{~h}$ would be optimal, though this may not always be practical. In the present study, feces collection intervals were only 1 hour, and the feces were kept with minimum quantity of water (in the collection tubes) in order to reduce nutrient leaching at maximum.

The industrial process of pelletizing in simple terms consist in taking raw materials finely ground, which, through the application of heat, moisture and mechanical pressure can be transformed into larger particles and stable nature. In the present study, the in-house prepared diets were cold pelleted, being a different process compared with the industrial steam pelleted. At present most commercial shrimp feeds are manufactured using conventional steam pelleting technology, with extended pre and/or post-pellet conditioning so as to produce water stable feeds. This is the inverse with fish feeds where most of the companies are using extrusion technology. The use of conventional steam pelleting technology for the production of shrimp 
feeds has been due to the need to produce fast sinking feeds because of the bottom feeding habits of crustaceans. Though, recent advances in extrusion technology has allowed the feed companies to produce sinking extruded shrimp feeds with improved nutrient digestibility and water stability compared with conventional pelleted shrimp feeds. Although the extrusion process requires a higher investment and operating costs, it is more profitable in terms of its ability to lower feed formulation costs, ability to utilize locally available ingredients, improve starch gelatinization and nutrient digestibility, reduce feed loss and water pollution, produce a wide range of feed particle sizes, ensure feed pasteurization and feed biosecurity, and reduce feeds costs per unit of production at the farm level (TACON, 2016). Also the smallest diameter of the extruded feed can be from $1 \mathrm{~mm}$. In the case of the pelletized, it can be from 2.0 to $2.3 \mathrm{~mm}$. In this way, the availability of food extruded is greater for each shrimp. During the experimental period a trend of lower feed intake was observed for the Commercial pelleted fed group than that for Commercial Extruded fed group. The observed attractability property of the extruded feed might have increased the feed intake, and consequently improved the animal performance. MISRA et al. (2002) working with post-larvae of Macrobrachium rosenbergii obtained better FCR in extruded pellet fed group than steam pellet fed group. They correlated the result with the lower feed intake of animals fed the extruded feed. These results are in agreement with the present study where better FCR were observed with the extruded diet. The poorer FCR of shrimp fed the Commercial Pellet might have been due to the over estimation of feed intake as it was more prone to leaching. The supposed better water stability of extruded pellet may have improved the feed efficiency of the Commercial Extruded fed group during the experimental period. 


\subsection{Conclusions}

The use of inert markers as a method of measuring the digestibility of a feed has been established in terrestrial animal nutrition. The adaptation of these marker techniques to aquaculture nutrition provides a tool for researchers that need to ensure the applicability and rapid transfer of research data to farmers, and industry. The use of endogenous dietary AIA as a marker in digestibility studies is easy and simple in that the method of determination is simple and does not involve costly equipment or chemicals, but may be difficult in that a high degree of precision and skill is needed during analysis for it. Most digestibility studies where AIA had not met the expectations of a suitable marker did not attribute this to marker failure, but to analytical inaccuracy due mainly to low AIA contents. On the basis of the present investigation, AIA has been shown to be an effective endogenous marker for digestibility trials with L. vanammei, however, for commercial feeds attention should be paid to the levels of AIA in the feed. The findings of this trial also highlight the importance of identifying suitable alternatives to chromic oxide as an inert marker for digestibility trials in shrimp.

Moreover, the Commercial Extruded feed showed better animal performance than Commercial Pelleted feed for L. vannamei juvenile. Extruded pellets promoted higher feed intake, better FCR, weight gain and protein utilization. However, apparent digestibility coefficients of both feeds were not significantly different from each other. The production of feeds for aquaculture is the fastest growing sector in the global feed industry. Although a large amount of shrimp feed is still produced by conventional pelletizer technology, extrusion is becoming utilized to a larger extent because it has several advantages over pelletizing which include the following:

1- Extruded feeds are usually capable of carrying higher fat levels than pelleted feeds;

2- For many species extrusion increases carbohydrate availability;

3- Extrusion can aid in the destruction of micro-organisms and some other contaminants;

4- Under some circumstances greater water stability can be achieved with extruded feeds;

5- A variety of local available ingredients can be readily incorporated into extruded products. 


\subsection{References}

AKIYAMA, D. M.; COELHO, S. R.; LAWRENCE, A. L.; ROBINSON, E. H. Apparent digestibility of feedstuffs by the marine shrimp Penaeus vannamei Boone. Nippon Suisan Gakkaishi, v. 55, p. 91-98. 1989.

ALDRICH. Handbook of Fine Chemicals and Laboratory Equipment, 2003-2004. SigmaAldrich, Castle Hill, NSW, Australia. 2003.

ALLAN, G. L.; ROWLAND, S. J.; PARKINSON, S.; STONE, D. A.; JANTRAROTAI, W. Nutrient digestibility for juvenile silver perch Bidyanus bidyanus: development of methods. Aquaculture, v. 170, p. 131-145. 1999.

ATKINSON, J. L.; HILTON, J. W.; SLINGER, S. J. Evaluation of acid-insoluble ash as an indicator of feed digestibility in rainbow trout Salmo gairdneri. Canadian Journal of Fisheries and Aquatic Sciences, v. 41, p. 1384-1386. 1984.

AZEVEDO, P. A.; CHO, C. Y.; LEESON, S.; BUREAU, D. P. Effects of feeding level and water temperature on growth, nutrient and energy utilisation and waste outputs of rainbow trout Oncorhynchus mykiss. Aquatic Living Resources, v. 11, p. 227-238. 1998

BORDNER, C. E.; D'ABRAMO, L. R.; CONKLIN, D. E. Assimilation of nutrients by cultured hybrid lobsters (Homarus sp.) fed experimental diets. Proceedings of the World Mariculture Society, v.14, p. 11-24. 1983.

BREMER NETO, H.; GRANER, C. A. F.; PEZZATO, L. E.; PADOVANI, C. R. Determinação de rotina do crômio em fezes, como marcador biológico, pelo método espectrofotométrico ajustado da 1,5- difenilcarbazida. Ciência Rural, v. 35, n. 3, p. 691$697,2005$.

BROWN, P. B.; WILLIAMS, C. D.; ROBINSON, E. H. Evaluation of methods for determining digestion coefficients for adult red swamp crayfish Procambarus clarkii. Journal of the World Aquaculture Society, v. 17, p. 19-24. 1986.

BURFORD, M. A.; WILLIAMS, K. C. The fate of nitrogenous waste from shrimp feeding. Aquaculture 198, 79-93. 2001.

CARVALHO, R. A. P. L.; LEMOS, D.; TACON, A. G. J. Performance of single-drain and dualdrain tanks in terms of water velocity profile and solids flushing for in vivo digestibility studies in juvenile shrimp. Aquaculture Engineering, v. 57, p. 9-17. 2013.

CHEVALIER, P. L.; WORMHOUDT, A. V. Alpha-glucosidase from the hepatopancreas of the shrimp, Penaeus vannamei (Crustacea-Decapoda). The Journal of Experimental Zoology, v. 280, p. 384-394. 1998. 
CHO, C. Y.; COWEY, C. B.; WATANABE, T. Finfish Nutrition in Asia. Methodological Approaches to Research and Development. Int. Development Research Centre, Ottawa, Canada, 154 pp. 1985.

COLVIN, P.M. Nutritional studies on penaeid prawns: protein requirements in compounded diets for juvenile Penaeus indicus (Milne Edwards). Aquaculture, v. 7, p. 315-326. 1976.

DAVIS, D. A.; ARNOLD, C. R. Evaluation of five carbohydrate sources for Penaeus vannamei. Aquaculture, v. 114, p. 285-292. 1993.

DAVIS, D. A.; ARNOLD, C. R.; MCCALlUM, I. Nutritional value of feed peas (Pisum sativum) in practical diet formulations for Litopenaeus vannamei. Aquaculture Nutrition 8, 87-94. 2002.

DE SILVA, S. S. Digestibility evaluations of natural and articial diets. In: S.S. De Silva (Editor), Proceedings of the Third Asian Fish Nutrition Network Meeting, Fish Nutrition Research in Asia. Asian Fisheries Society, Special Publication 4, Manila (Philippines), pp. 36-45. 1989.

DE SILVA, S. S. Evaluation of the use of internal and external markers in digestibility studies. In: C.Y. Cho, C.B. Cowey, T. Watanabe (Editors), Finfish Nutrition in Asia. Methodological Approaches to Research and Development, International Development Research Centre, Ottawa (Canada), pp. 96-102. 1985.

DE SILVA, S. S.; ANDERSON, T. A. Fish Nutrition in Aquaculture. Chapman and Hall, London, 319 pp. 1995

DE SILVA, S. S.; PERERA, M.K., MAITIPE, P. The composition, nutritional status and digestibility of thediets of Sarotherodon mossambicus from 9 man-made lakes in Sri Lanka. Environmental Biology of Fishes, v. 11, p. 205-219. 1984.

DEERING, M. J.; HEWITT, D. R.; SARAC, H. Z. A comparison of inert markers used to estimate protein digestibility in the leader prawn Penaeus monodon. Journal of World Aquaculture Society, v. 27, p. 103-106. 1996.

DIVAKARAN, S. Chromic oxide: The inert marker for in vivo digestibility studies in shrimp, problems and solutions. Aqua Feeds: Formulation and Beyond, v. 2, p. 28-29. 2005.

DIVAKARAN, S.; VELASCO, M.; BEYER, E.; FORSTER, I.; TACON, A. G. J. Soybean meal apparent digestibility for Litopenaeus vannamei, including a critique of methodology. In: Cruz -Suárez, L.E., Ricque-Marie, D., Tapia-Salazar, M., Olvera-Novoa, M.A. y CiveraCerecedo, R., (Eds.) Avances en Nutrición Acuícola V. Memorias del V Simposium Internacional de Nutrición Acuícola. 19-22 Noviembre, 2000. Mérida, Yucatán, México. 2000 .

FAO 2016. Fisheries and aquaculture software. FishStatJ - software for fishery statistical time 
series. In: FAO Fisheries and Aquaculture Department [online]. Rome. Released March 2016. Available at http://www.fao.org/fishery/statistics/software/fishstatj/en. 2016.

FORSTER, J. R. M.; GABBOT, P. A. The assimilation of nutrients from compounded diets by the prawns Palaemon serratus and Pandalus platyceros. Journal of the Marine Biological Association of the United Kingdom, v. 51, p. 943-961. 1971.

GARCIA-CARRENO, F. L.; NAVARRETE DEL TORO, A.; EZQUERRA, J. M. Digestive shrimp proteases for evaluation of protein digestibility in vitro: I. Effect of protease inhibitors in protein ingredients. Journal of Marine Biotechnology 5, 36-40. 1997.

JONES P. L.; DE SILVA, S. S. Comparison of internal and external markers in digestibility studies involving the Australian freshwater crayfish, Cherax destructor Clark (Decapoda, Parasta- cidae). Aquaculture. Research, v. 29, p. 487-493. 1998.

JONGBLOED A. W.; BAKKER, J. G. M.; GOEDHART, P. W.; KROL-KRAMER, F. Evaluation of chromic oxide with lower concentration and of $\mathrm{HCl}$-insoluble ash as markers for measuring overall apparent digestibility of some dietary nutrients for pigs. Proceedings of the 5th International Symposium on Digestive Physiology in Pigs, Wageningen, (The Netherlands), pp. 325-329. 1991.

KOTB, A. R.; LUCKEY, T. D. Markers in nutrition. Nutrition Abstracts and Reviews, v. 42, p. 813-845. 1972.

KWANYUEN, P., BURTON, J.W. A Modified Amino Acid Analysis Using PITC Derivatization for Soybeans with Accurate Determination of Cysteine and Half- Cystine. Journal of American Oil Chemistry Society, v. 87, p. 127-132. 2010.

LAN, C.C.; PAN, B. S. In-vitro digestibility simulating the proteolysis of feed protein in the midgut gland of grass shrimp (Penaeus monodon). Aquaculture, v. 109, p. 59-70. 1993.

LEAVITT, D. F. An evaluation of gravimetric and inert marker techniques to measure digestibility in the American lobster. Aquaculture, v. 47, p. 131-142. 1985.

LEE, P. G.; LAWRENCE, A. L. Digestibility. In: D’Abramo, L/R/, Conklin, D.E., Akiyama, D.E. (Eds.), Crustacean Nutrition. World Aquaculture Society, Baton Rouge, LA, USA, pp. 194-260. 1997.

MCCARTHY, J. F., AHERNE, F. X., OKAI, D. B. Use of $\mathrm{HCl}$ insoluble ash as an index material for determining apparent digestibility with pigs. Canadian Journal of Animal Science, v. 54, p. 107-109.1974.

MISRA, C. K.; SAHU, N. P.; JAIN, K. K. Effect of extrusion processing and steam pelleting diets on pellet durability, water absorption and physical response on Macrobrachium rosenbergii. Asian-Australasian Journal of Animal Sciences, v. 15, p. 1354-1358. 2002. 
MORALES, A. E.; CARDENETE, G.; SANZ, A.; DE LA HIGUERA, M. Re-evaluation of crude fibre and acid-insoluble ash as inert markers, alternative to chromic oxide, in digestibility studies with rainbow trout Oncorhynchus mykiss. Aquaculture, v. 179, p. 7179. 1999.

NUNES, A. J. P.; ROCHA, I. P. Overview and latest developments in shrimp and tilapia aquaculture in Northeast Brazil. World Aquaculture, Baton Rouge, EUA, v. 46, p. 10-17. 15 jun. 2015.

PERERA, W. M. K.; CARTER, G. C., HOULIHAN, D. F. Apparent absorption efficiencies of amino acids in rainbow trout, Oncorhynchus mykiss (Walbaum), fed diets containing bacterial single-cell protein. Aquaculture Nutrition. 1, 95-103. 1995.

RYMER, C. The measurement of forage digestibility in vivo. In: D.I. Givens, E. Owen, R.F.E. Axford, H.M. Ohmed (Editors). Forage Evaluation in Ruminants. CABI International, Walling- ford, Oxon (UK), pp. 113-132. 2000.

SALES J.; BRITZ, P. J. Evaluation of different markers to determine apparent nutrient digestibility coefficients of feed ingredients for South African abalone, (Haliotis midae L.). Aquaculture, v. 202, p. 113-129. 2001.

SCOTT T. A.; SILVERSIDES, F. G.; CLASSEN, H. L.; SWIFT M. L.; BEDFORD, M. R.; HALL, J. W. A broiler chick bioassay for measuring the feeding value of wheat and barley in complete diets. Poultry Science, v. 77, p. 449-455. 1998.

SCOTT, T. A.; BALDAJI, F. Comparison of inert markers [chromic oxide or insoluble ash $\left(\right.$ Celite $\left.{ }^{\circledR}\right)$ ] for determining apparent metabolizable energy of wheat-or barley-based broiler diets with or without enzymes. Poultry Science, v. 76, p. 594-598. 1997.

SEIDMAN, E. R.; LAWRENCE, A.L. Growth, feeding digestibility and proximate body composition of juvenile Penaeus vannamei and Penaeus monodon growth at different dissolved oxygen levels. Journal of World Mariculture Society, v. 16, p. 333-346. 1986.

SHIAU, S. Y.; LIANG, H. S. Carbohydrate utilization and digestibility by tilapia, Oreochromis niloticus x $O$. aureus, are affected by chromic oxide inclusion in the diet. Journal of Nutrition, v. 125, p. 976-982. 1995.

SMITH, D. M.; TABRETT, S. J. Accurate measurement of in vivo digestibility of shrimp feeds. Aquaculture, v. 232, p. 563-580. 2004.

SMITH, L. L.; LEE, P. G.; LAWRENCE, A. L.; STRAWN, K. Growth and digestibility by three sizes of Penaeus vannamei Boone: effects of dietary protein level and protein source. Aquaculture, v. 46, p. 85-96. 1985.

TACON, A. G. J. Risks and benefits of extruded shrimp feeds. Asian-Pacific Aquaculture 2016 Meeting Abstract. Available at https://www.was.org/meetings. 2016. 
THONNEY, M. L.; PALHOF, B. A.; DECARLO, M. R.; ROSS, D. A.; FIRTH, N. L.; QUAAS R. L.; PEROSIO, D. J.; DUHA-IME, D. J.; ROLINS, S.R.; NOUR, A. Y. M. Sources of variation of dry matter digestibility measured by the acid insoluble ash marker. Journal of Dairy Science, v. 68, p. 661-668. 1985.

VAN KEULEN, J.; YOUNG, B. A. Evaluation of acid-insoluble ash as a natural marker in ruminant digestibility studies. Journal of Animal Science, v. 44, p. 282-287. 1977.

VAN WYK, P.; DAVIS-HODGKINS, M.; LARAMORE, C.R.; MAIN, K.; MOUNTAIN, J., SCARPA, J. Farming marine shrimp in recirculating freshwater production systems: A practical manual. FDACS Contract \#4520. Florida Department of Agriculture Consumer Services, Tallahassee, FL, US. 1999.

VOGTMANN, H.; PFIRTER, H. P.; PRABUCKI, A. L. A new method of determining metabolizability of energy and digestibility of fatty acids in broiler diets. British Poultry Science, v. 16, p. 531-534. 1975.

WETHERBEE, B. M.; GRUBER S. H. Use of acid-insoluble ash as a marker in absorption efficiency studies with the lemon shark. Progressive Fish-Culturist, v. 55, p. 270-274. 1993.

WYBAN, J.; WALSH, W.A.; GODIN, D.M. Temperature effects on growth, feeding rate and feed conversion of the Pacific white shrimp (Penaeus vannamei). Aquaculture, v. 138, p. 267-279. 1995. 


\section{CHAPTER 3}

Feeding of juvenile cobia Rachycentron canadum:

Evaluation of practical feeds in floating net cages and comparison of different dietary fishmeal replacers within indoor tanks 


\section{Preface}

This chapter contains the result of my research undertaken at the Instituto Oceanográfico of Universidade de São Paulo, Brazil, with financial support of the Coordination for the Improvement of High Level Education Personnel (CAPES), as part of the activities of the AquaMar Research Project "Feeding Tomorrow's Fish: Environmental and Sustainable Aquaculture Feeds and Feeding Regimes for Marine Farming”. The information contained in this chapter has been presented in national conferences, as follow:

RAGGI, T.; LEMOS, D.; TACON, A. G. J. Feeding and nutrition of cobia, Rachycentron canadum, in floating net cages: performance and digestibility. In XI Feira Nacional do Camarão. Fortaleza, Ceará, Brazil. 10 -13 November, 2014.

RAGGI, T.; LEMOS, D.; ALVES, J. M. C.; YASUMARU, F.; FREITAS, L. F.; OTA, R. H.; TACON, A. G. J. Fishmeal replacement by animal and plant source proteins in practical diets for cobia, Rachycentron canadum: performance and digestibility. In XII Feira Nacional do Camarão. Fortaleza, Ceará, Brazil. 16 -19 November, 2015. 


\section{Abstract}

Two feeding trials were conducted with juvenile cobia, Rachycentron canadum, at the Oceanographic Institute, University of São Paulo, Ubatuba, SP, Brazil: (1) a 10-week feeding trial conducted within floating net cages to test the nutritional efficacy of different dietary feeding regimes ranging from the use of trash-fish, in-house formulated feeds, to dry commercial extruded marine fish feed; and (2) a 10-week feeding trial conducted within indoor waterrecirculated tanks to test the nutritional efficiency of different potential dietary fishmeal replacers within dry in-house prepared diets.

Different commercially-based diets were tested within floating net cages, including a trash-fish control diet, a semi-moist diet composed of trash-fish and a binder premix, an in-house dry formulated diet, and one commercially available extruded marine fish feed. In the case of the indoor tank-based feeding trial, different practical-type diets were formulated and manufactured containing $50 \%$ crude protein from different animal and plant protein sources, including a national fishmeal diet, a salmon fishmeal diet, a poultry-by-product meal diet, a soy protein concentrate meal diet, and a combination of poultry-by-product meal and feather meal diet. In addition to the above different protein sources, a diet was also tested without supplemental taurine together with a dry commercial fish feed. Juvenile cobia (initial weighting $127 \mathrm{~g}$ for the cage study and $89 \mathrm{~g}$ for the tank study) were randomly stocked in both systems and hand-fed $a d$ libitum two times daily at approximately 09:00 and 14:00 h. Fish were group weighed biweekly to monitor growth performance. Feces were collected 3-4 h post feeding at each collection period by the fecal stripping technique, in order to assess dry matter and crude protein apparent digestibility coefficient.

Generally, fish performance was superior in the net-cage feeding trial compared with the indoor water-recirculated tank trial. Fish weight gain in both feeding trials were not significantly different between the experimental diets, with the exception of fish fed the trash-fish control diet which displayed the best growth response and feed performance. Overall, the fish growth and performance of the experimental diets were very similar, showing that the alternative ingredients could be included and replace part (50\%) of the fishmeal component. Apparent crude protein digestibility coefficients of over $80 \%$ were obtained for all diets from both trials. The results from both trials concluded that the cobia requires practices diets with high levels of crude protein 
and lipid, and the inclusion of alternative plant-based and terrestrial animal protein sources was possible.

Comparing the estimated essential amino acid (EAA) requirements of juvenile cobia using two different approaches (protein accretion and E/A ratio), an underestimation of the EAA requirement values was noticed when lysine was used as the reference EAA. The quantitative EAA requirement values estimated by the protein accretion method was highly correlated to the average of each of the EAA requirement for the species of carnivorous fish reported in the literature, and could be recommended for formulation of commercial feed for cobia. Using amino acids profile to set basis for dietary amino acids profile and requirements is a viable technique and may bring additional benefits of formulating diets eliciting higher feeding efficiency and reduced nutrient loss and waste and metabolites excretion. Also, the results suggest the need for nutritional improvement of existing commercial diets currently employed for cobia production in Brazil. 


\subsection{Introduction}

Species overview

Cobia, Rachycentron canadum (Linnaeus), are a carnivorous pelagic fish, distributed worldwide, with the exception of the eastern Pacific Ocean, in sub-tropical, tropical and temperate waters (BRIGGS, 1960). Cobia display many characteristics that are favorable for aquaculture, primarily due to their rapid growth, with fingerlings reaching a marketable size of 4$6 \mathrm{~kg}$ within a year (CHOU, et al., 2001). Other benefits include low production cost coupled with a high market value due to its high quality white fillet. In Japan, the belly portion with its high lipid content is highly valued and the fillets are suitable for the sashimi (raw fish) industry (CHOU et al., 2001). Furthermore, cobia display good feed efficiency ratios (FAULK; HOLT, 2003; ZHOU et al., 2006), readily accept commercially formulated dry diets (CHOU et al. 2001), spawn readily in captivity (FAULK; HOLT, 2005), have high fecundity (FAULK; HOLT, 2005), a high survival rate on post-weaning (LIAO et al., 2004), good larval production prospects (BENETTI et al., 2008), ability to withstand variations in salinity (RESLEY et al., 2006), and also display a beneficial response to vaccination, probiotics and immune-stimulants (BENETTI et al., 2008; GENG et al., 2011, 2012).

Due to these favorable production-related characteristics cobia aquaculture has been growing in popularity since the early 1990s especially in Asia, and in particular within China and Taiwan, and more recently within the United States of America, the Caribbean, Central America, Brazil, Australia and the Marshall Islands (BENETTI et al., 2008). Cobia typically are cultured in near-shore sea cages, and more recently in land-based recirculating systems and ponds (LIAO et al., 2004). Cobia aquaculture has risen dramatically over the last decade, however, only recently has work been published on the specific nutritional requirements of this species due in part to the relative success of existing commercial compounded feeds which give a good indication of the nutritional requirement of this fish. At present, commercial cobia feeds are based on those for Asian sea bass or grouper and achieve acceptable growth with feed conversion ratios (FCRs) ranging from 1.5 to 1.8. Currently, in areas such as Taiwan where cobia culture is particularly popular, animals are being fed once daily at a feeding rate of 0.5 - 
$0.7 \%$ of body weight on a pelleted feed containing $42-45 \%$ of crude protein and $15-16 \%$ of fish oil, with an FCRs of about 1.5 during the grow-out stage (LIAO et al., 2004).

The world production of cobia has been increasing gradually, and in 2014, 40,326 tonnes were reportedly produced (FAO, 2016). Most cobia is produced in near-shore floating cages in China, Taiwan and Vietnam (NHU et al., 2011; FAO, 2016), but there is also a trend toward offshore aquaculture (KAPETSKY et al., 2013). Although marine fish farming currently has few commercial importance in Brazil (MPA, 2015), a recent study indicates that Brazil has one of the greatest offshore aquaculture potentials in the world (KAPETSKY et al., 2013). In the last 5 years, two offshore cobia farms were deployed off Recife, northeastern Brazil, and smaller-scale, near-shore cobia farming operations are currently ongoing in Rio de Janeiro and São Paulo (BEZERRA et al., 2015). In order to this industry to continue its expansion into the future there is a necessity for increasing the general knowledge of cobias basic nutritional requirements.

\section{Feeding habits}

Feeding habits of cobia in the wild have been evaluated with the help of recreational fishermen, with sampling events off the coast of USA (FRANKS et al., 1996). Some studies have demonstrated that cobia are opportunistic carnivores that feed primarily on benthic and epibenthic crustaceans and fish (KAISER; HOLT, 2004). In one study, prey items were divided into size classes and grouped into four categories (shrimp, crabs, teleost fishes, and elasmobranch fishes) to determine changes in food habits with growth (SMITH, 1995). Of the 110 stomachs examined from cobia caught off the coast of North Carolina, 24 species of crustaceans, 16 species of fishes, and 1 cephalopod were identified (SMITH, 1995). The largest amounts of crustaceans found included iridescent swimming crab Portunus gibbesii, brown shrimp Penaeus aztecus, mantis shrimp Stomapotapods, coarsehand lady crab Ovalipes stephensoni, blotched swimming crabs Portunus spinimanus, and rock shrimp Sicyonia brevirostris. Smaller cobia seemed to eat penaeid shrimps and teleost fishes, but as the cobia got larger, the consumption of decapod crab, and elasmobranchs such as smooth dogfish and sting rays increased (SMITH, 1995). FRANKS et al. (1996) examined the stomach contents of 49 juvenile cobia caught in the northern Gulf of Mexico and found that their diets consisted of mainly fishes, crustaceans, and cephalopods. Fish were predominant and anchovies were leading 
among them. Crustaceans ranked first in terms of numeric importance, with decapods being the most common. Only two species of cephalopods were found in cobia stomachs, slender inshore squid and longfin inshore squid. Smaller juvenile cobia tended to prefer crustaceans and fishes, while the larger juveniles preferred fishes. MEYER; FRANKS (1996) reported that adult cobia in the north-central Gulf of Mexico typically ate fishes, crustaceans, and cephalopods as well, with crustaceans being the primary food source. FRANKS et al. (1996) also noticed that juveniles tended to feed during the daylight. Since cobia are very strong swimmers and aggressive feeders, they are very capable of catching moving prey objects (FRANKS et al., 1996), and the contents of their stomachs are evidence of this fact. These findings are very important in order to develop compound feeds for a species with a limited knowledge in terms of their feeding habits and dietary nutritional requirements.

\section{Cobia nutrient requirements}

Since cobia is quickly becoming an important species for aquaculture, it is essential to determine their optimal quantitative nutritional requirements. Juvenile cobia exhibit very rapid growth rates, and in order to maximize their true growth potential, protein, lipid, carbohydrate and energy requirements must be determined so that cost-effective feed formulations can be developed. It also is necessary to determine optimum feeding rates, feeding frequencies and feeding methods in order to further improve feed conversion ratios.

Despite the global interest in cobia, relatively few studies have been conducted which focus on quantitative nutritional requirements. To date most studies have concentrated on optimal levels of dietary lipid and protein, the digestibility of selected feed ingredients, and the replacement of fishmeal with alternative dietary protein sources. The optimal dietary protein and lipid levels for juvenile cobia have been determined by varying the percentage of dietary protein from 36 to $60 \%$ and lipid from 3 to $18 \%$ (CHOU et al., 2001). Cobia fed diets containing 44, 48, and $52 \%$ protein exhibited higher weight gain and feed conversion than cobia fed other diets, but weight gain showed a peak at $44.5 \%$ dietary protein, so this was determined to be the most suitable level for maximum growth (CHOU et al., 2001). For lipid, weight gain tended to increase with dietary lipid content, but leveled off around $5.76 \%$, so this is thought to be the optimal level of dietary lipid for cobia (CHOU et al., 2001). A second study conducted by HER 
et al. (2001) used protein levels of 37, 41, and 45\% along with lipid levels of $0,5,10$, and 15\% and dietary energy levels of 307, 347.6, 389.8, and $432.4 \mathrm{kcal}$ per $100 \mathrm{~g}$ diet to determine the optimal protein/energy ratio. Results showed that cobia fed a diet containing $37 \%$ protein and $15 \%$ lipid exhibited statistically similar growth and feed conversion ratios to cobia fed diets containing 41 and $45 \%$ protein along with high energy levels. This study determined that the optimal dietary protein/energy ratio for cobia was $86-115 \mathrm{mg}$ protein $/ \mathrm{kcal}$, and that a diet containing $37 \%$ protein and an energy level of $432 \mathrm{kcal}$ supports optimal growth. This reduction in protein level, but increase in lipid level and energy shows the possible protein-sparing effects of lipid in cobia diets. However, CRAIG et al. (2006) did not observe protein sparing by lipid in a 3 x 2 factorial design with protein levels of 40 and 50\% crude protein (CP) and lipid levels of 6, 12 and 18\% total lipid (dry weight basis). There were no significant differences in weight gain or feed efficiency ratios in this study utilizing 12 and $44 \mathrm{~g}$ juvenile cobia. One other study has evaluated the impact of dietary lipid on growth, feed utilization, lipid deposition, and lipid metabolism of juvenile cobia (WANG et al., 2005). Diets consisted of $47 \%$ protein and lipid levels of either 5, 15, or $25 \%$. Results showed that lipid levels higher than $15 \%$ had a negative effect on growth, and as lipid level increased, there was a decline in feed intake. Increasing the amount of dietary lipid also led to an increase in tissue and whole-body lipid levels. Cobia deposited fat in the muscle and viscera when fed 5 and 15\% lipid, whereas cobia fed 25\% lipid tended to deposit fat in adipose tissue and muscle. Nitrogen intake and gain were significantly lower in the $25 \%$ lipid diet, but muscle protein was unaffected by dietary lipid level. Hence, lipid levels above $15 \%$ were not beneficial due to accumulation of fat and decreased growth, and there was no evidence that protein could be spared by dietary lipid (WANG et al., 2005).

Commercial production facilities currently utilize a wide range of dietary formulations, mainly due to the limited information on quantitative nutritional requirements for cobia. In the Asia/Pacific region, including Taiwan, China and Vietnam, cobia typically is fed a diet consisting of $42-45 \%$ crude protein and $15-16 \%$ lipid on a dry weight basis (LIAO et al., 2004). These fish are usually fed once a day, six days a week at a feeding rate of $0.5-0.7 \%$ body weight (LIAO et al., 2004). In North American facilities, current formulations utilized for grow out of juvenile cobia range from 50-59\% crude protein and 14-17\% total lipid (dry weight basis). While there are conflicting data concerning the ability of cobia to utilize lipid in place of protein, these 
higher lipid levels can contribute to a more desirable final product in terms of the sashimi market, but excessively high protein levels (> 50\% CP dry matter basis) are not cost effective and should be lowered, not only for economic, but also for environmental reasons (CRAIG et al., 2006).

These studies clearly illustrate that like many other species of fish, body composition of cobia can be manipulated by dietary inputs (PERES; OLIVA-TELES, 1999; WANG et al., 2005). One study conducted by TURNER; ROOKER (2005) involved the impact of four different diets on the fatty acid profile and growth of juvenile cobia. One diet, which served as their control diet, was a commercial feed, while the other three consisted of wild-caught fish, shrimp, or squid. The results showed that juvenile cobia fed the control diet and the squid diet grew significantly larger than cobia fed the other diets. A significant difference in levels of all individual polyunsaturated fatty acids (PUFAs) was also noticed among the diets. Among diets, the squid diet seemed to exhibit the highest dietary fatty acid contribution, followed by the shrimp diet, and then the fish diet. Juveniles fed the different diets began to exhibit different PUFA signatures from day 49 to day 61 . These data show a connection between growth, increase in biomass, and dietary PUFA composition because the cobia fed the squid diet grew the largest, had the greatest increase in relative biomass, and received the highest amount of dietary PUFAs. However, it was also noticed in this study that the cobia fed the shrimp diet exhibited the highest increase in relative biomass based on percent contribution of dietary fatty acids. This is currently the only study that deal with growth and fatty acid profiles of juvenile cobia that are fed wildcaught diets.

A more recent area of research that has raised considerable interest is the area of bioenergetics. The main goal of aquaculturists and nutritionists is to achieve maximum growth. Since growth seems to be the last in line for obtaining energy, it becomes very important to understand how a fish distributes its energy to functions other than growth (SMITH, 1989). Two recent bio-energetic studies have also been conducted using juvenile cobia. SUN et al. (2006a) used a feed (Anguilla sp.) formulated for eel feed with five ration levels (starvation, 3\%, 6\%, and $9 \%$ of initial body weight and ad libitum) to determine the growth-ration relationship and energy budget for cobia (initial body weight $10 \mathrm{~g}$ ). Fecal production significantly increased with increased ration. The optimal ration for juvenile cobia was $9 \%$ because specific growth rate also 
increased with increased ration, but there was no significant difference observed between the $9 \%$ and ad libitum ration. Also, feed conversion efficiency increased with ration up to $9 \%$ and then decreased at ad libitum. The proportion of energy intake that was retained as growth ranged from 6.5 to $22.1 \%$ and was the highest at the $9 \%$ ration per day. Another experiment conducted by SUN et al. (2006b) used three different feed types [natural sardine fish (NSF), commercial eel formulated feed (CEFF), and commercial marine fish formulated feed (CMFF)] and four ration levels varying between starvation and ad libitum to investigate growth, fecal production, nitrogenous excretion, and energy budget of cobia (initial body weight $28 \mathrm{~g}$ ). The chemical composition of the fish was affected by both feed and ration. As ration increased, so did protein, lipid, and energy content of the fish. Protein, lipid and energy contents were highest for fish fed the NSF and CEFF-feeds and lowest for the CMFF feed. Both fecal production and nitrogenous excretion were higher with increased ration for each feed type. Fecal production was highest for fish fed CMFF and lowest for the NSF feed, and nitrogenous excretion was the opposite. In general, specific growth rates (SGR) and feed efficiencies (FE) for the NSF and CEFF fed cobia were superior to the cobia fed the CMFF feed. Their results indicated that the NSF feed was preferred by juvenile cobia, and that ration levels between 70 and $100 \%$ of satiation appeared suitable.

\section{Amino acid requirement}

There have been a limited number of studies into the specific amino acid requirements of cobia. Indeed, only three out of the ten considered essential amino acids (WILSON, 2002) have been investigated. Currently there are no reports in the literature of amino acid related deficiency in cobia fed commercial diets suggesting this species has similar requirements to those of other commonly cultured marine fish. ZHOU et al. (2006) determined the requirement of methionine in juvenile cobia in terms of maximum growth and lowest FCR, to be $1.19 \%$ of dry diet in the presence of $0.67 \%$ cysteine, corresponding to $2.64 \%$ of dietary protein dry weight. This supports the preliminary estimate of $2.66 \%$ (methionine + cysteine) when expressed as percent of dietary protein determined previously by CHOU et al. (2004). ZHOU et al. (2007) also determined the requirement of lysine in juvenile cobia to be $2.33 \%$ of dry diet (5.30\% dietary protein). These values for methionine and lysine are in accordance with those of commonly cultured fish, 1.83.2\% and 3.2-6.2\% dietary protein, respectively (WILSON, 2002). 
In addition, SALZE et al. (2012) suggested that taurine was an essential nutrient for cobia larvae. WATSON et al. (2014) showed that increasing dietary taurine in a diet containing $34.5 \%$ fishmeal did not result in significantly different growth or production characteristics in cobia, but did result in significantly increased taurine levels in fillet, liver, and plasma. LUNGER et al. (2007) found that taurine supplementation does have a significant impact on growth and feed efficiency of juvenile cobia when they are fed diets containing high levels of plant-based proteins as replacement for fishmeal.

CHI et al. (2014) suggested that supplementation of a low-fishmeal diet with crystalline methionine $(0.3 \%)$ improves body weight gain and exerts a beneficial effect on juvenile cobia reared under laboratory conditions for 60 days. The arginine requirement for cobia (initial weight $14.7 \mathrm{~g}$ ) was estimated to be $5.17 \%$ of dietary protein (ZHAO et al., 2007), which is lower than $6.20 \%$ (dietary protein) obtained by REN et al. (2014) (initial weight $3.8 \mathrm{~g}$ ). The variances between two studies are possibly reflected by: fish of different sizes, initial weight $3.38 \mathrm{~g}$ compared with $14.7 \mathrm{~g}$; different ingredients as intact protein sources, commercial ingredients compared with casein and gelatin; experimental conditions, indoor flow-through aquaria compared with outdoor net cage. However, there is no information about glutamate being used for the endogenous synthesis of arginine in cobia, at least in channel catfish, glutamate appears to spare up to $33 \%$ of the arginine requirement (BUENTELLO; GATLIN, 2000).

Various researchers have observed improved growth and feed efficiency when experimental diets were supplemented with essential amino acid (EAA) to simulate levels found in isolated fish protein or the respective eggs and whole-body tissue of the species being studied (RUMSEY; KETOLA, 1975; ARAI, 1981; OGATA et al., 1983). The EAA requirements of certain fish have also been shown to correlate well with the indispensable amino acid profile of the whole-body tissue of that fish (COWEY; TACON, 1983; WILSON; POE, 1985). Therefore, it seems reasonable to suggest that these types of information may be useful in designing test diets for fish when their amino acid requirements have not been established, as cobia.

On the basis of observations in other animals, COWEY; TACON (1983) suggested that the EAA requirements of fish species should be related to, or even governed by, the profile of amino acids present in muscle tissue. They showed a high correlation between the requirement 
pattern found by feeding experiments for the 10 EAA as determined for carp by NOSE (1979) using amino acid test diets and the profile of the same amino acids in the whole-body tissue of growing carp. WILSON; POE (1985) also have tested this hypothesis in channel catfish. They obtained a regression coefficient of 0.96 when the EAA requirement profile for the channel catfish was regressed against the whole-body EAA profile found in a 30-g channel catfish. A lower regression coefficient of 0.68 was found when the requirement profile was regressed against the channel catfish egg amino acid profile. They concluded that the amino acid profiles of whole body could be used in formulating fish feeds until consistent requirement data were available for that species.

OGINO (1980) estimated the EAA requirements of common carp and rainbow trout based on the amounts of each amino acid retained in the carcass of the animal fed a high-quality protein diet and resulting in elevated growth. This method has been used to estimate the amino acid requirements of the Mozambique tilapia Oreochromis mossambicus (JAUNCEY et al., 1983), Siberian sturgeon Acipenser baerii (KAUSHIK et al., 1991), white sturgeon Acipenser transmontanus (NG; HUNG, 1995), Arctic charr Salvelinus alpinus (GURURE et al., 2007), prawn Marsupenaues japonicus (TESHIMA et al., 2002), and sea bass Dicentrarchus labrax (GABER et al., 2015). Even though it is generally accepted that this technique provides an ideal profile of EAA for protein accretion, it is questionable whether the net amino acid retention values can actually be used to establish the amino acid requirements for maximum growth. In general, the requirement values estimate by this method are lower than those determined by dose-responde growth studies. This may be due to the fact that normally only about 30 to $40 \%$ of dietary nitrogen is retained by growing fish (NRC, 2011).

ARAI (1981) used A/E ratios [(EAA content/total EAA including cysteine and tyrosine) $\times$ 1000] of whole-body Coho salmon fry to formulate test diets for this fish specie. Fish fed casein diets supplemented with amino acids to simulate the $\mathrm{A} / \mathrm{E}$ ratios of whole-body tissue showed much improved growth and feed efficiency. OGATA et al. (1983) used A/E ratios based on amino acid composition data from Cherry salmon to design test diets for Cherry and Amago salmon fry. A casein diet supplemented with amino acids to simulate the $\mathrm{A} / \mathrm{E}$ ratios of cherry salmon resulted in better growth in both species than diets containing casein alone, casein plus amino acids to simulate the $\mathrm{A} / \mathrm{E}$ ratio of eyed cherry salmon eggs, or white fishmeal. Amino acid 
ratios have been used as a means of estimating the requirements of all EAA when requirement of only one $\mathrm{AA}$ is known by relating the $\mathrm{A} / \mathrm{E}$ ratio of each $\mathrm{EAA}$ to that of the $\mathrm{A} / \mathrm{E}$ ratio of the known AA times the requirement value for the known AA (MOON; GATLIN, 1991). This technique has also been used by other investigators to estimate the amino acid requirements of fish (FORSTER; OGATA, 1998; MOON; GATLIN, 1991; PORTZ; CYRINO, 2003; TWIBELL et al., 2003).

The relationship between whole-body amino acid profiles and amino acid requirement profiles discussed above is very similar to the ideal protein concept that has been advocated for use in expressing the amino acid requirements of swine (Agricultural Research Council, 1981). The ideal protein concept is based on the idea that there should be a direct correlation between the whole-body amino acid profile of the animal and the dietary amino acid requirements of that animal. In addition, since lysine is normally the first limiting amino acid in most feedstuffs, the requirements for the other indispensable amino acids are expressed relative to the lysine requirement. Thus, if one knows the dietary lysine requirement and the whole-body amino acid composition of an animal, then one should be able to estimate the dietary requirement for the remaining indispensable amino acid requirements of the animal relative to the lysine requirement.

\section{Fishmeal replacement}

Fishmeal is generally considered to represent the "gold standard" dietary protein source for carnivorous fishes. However, even though the animal feeds and competing industries have increased demands for fishmeal, global production of this commodity has remained relatively stable over the last decade, and supplies are unlikely to increase (FAO, 2014). Indeed, the increasing scarcity of suitable protein sources for human consumption may result in the use of industrial fish for the plate, resulting in a further weakening in supplies (CRAIG; MCLEAN, 2005). Already, aquafeeds account for $>50 \%$ of variable operating costs of intensive aquaculture operations, with dietary lipids and protein representing the costliest nutrient sources (TACON, 1997). If aquaculture is to continue to expand to meet global demands for seafood products, development of cost-effective and sustainable dietary formulations will be mandatory. This only can occur through significant reductions in the dependence of the aquafeed industry upon 
fishmeal supplies. Because fishmeal represents a finite resource and as it has become more expensive over time (FAO, 2014), it is not surprising to find that the aquafeed industry has sought out alternative, less expensive, protein sources. For alternative or supplemental proteins to be useful, however, they must possess certain characteristics. Alternative proteins must be competitively priced relative to fishmeal on a unit protein basis. They cannot negatively impact fish performance (digestibility, growth, disease resistance, etc.) or product quality and must be commodities (i.e., traded internationally) (HARDY; TACON, 2002). As well, alternative ingredients must not be environmentally degrading with respect to nitrogen and phosphorus discharge and should be easily handled, stored and amenable to pelleting. Because of these restrictions, there presently exists, only few number of potential candidates. These include the pulses, oilseeds, grains, rendered animal meals, processing discards and fishery by-catch. Soybean meal, in particular, represents one of the most widely-used alternate protein sources employed by aquaculture, due to its global availability, cost, relatively high digestibility, good amino acid profile and high protein content (STOREBACKKEN et al., 2000). Nevertheless, soybean and other alternative protein meals each contain a variety of anti-nutritional factors that negatively impact production performance of cultured fish (FRANCIS et al., 2001).

Recently there has been great interest in the area of dietary fishmeal replacement for cobia. Some researchers have conducted studies with alternate plant-based ingredients, mainly soybean meal (CHOU et al., 2004; LUNGER et al., 2006; WANG et al., 2004; ZHOU et al., 2004,2005 ) indicating that soybean meal can replace up to $40 \%$ of fishmeal without adversely affecting growth or protein utilization. Also, some animal by-products ingredients have been tested as fishmeal substitutes (LUNGER et al., 2007; ZHOU et al., 2004; SAADIAH et al., 2011). Amino acid requirements require specific attention when replacing fishmeal with alternative products. To date there is very little data available on the amino acid requirements of cobia, reducing the ability to determine the potential limiting amino acids when replacing fishmeal with alternate protein sources. However, CHOU et al. (2004) suggested methionine would be the limiting amino acid based on a study using soybean meal as an alternate protein. Methionine concentrations decreased from 2.52 to $1.36 \mathrm{~g}(\% \mathrm{CP})$ as the soybean meal protein replacement level was increased from $0 \%$ to $60 \%$ while all other EAA remained relatively constant. Interestingly, taurine supplementation at $0.5 \%$ dry diet increased fish weight and 
improved FEs in juvenile cobia fed diets containing high levels of plant-based proteins (LUNGER et al., 2007). Taurine supplementation would also appear to improve feed palatability of diets containing high levels of plant-based protein, a result also observed by BROTONSMARTINEZ, (2004) in European sea bass fry.

\section{Objectives}

The objectives of the present work were:

1- Develop management and feeding protocols for cobia produced in floating net cages and fed with practical and commercial diets;

2- Analyze the diet and whole body amino acid composition of cobia fed a high-quality protein diet in order to estimate their EAA requirements, based on the amounts of each amino acid retained in the carcass;

3- Compare the estimated EAA with the present estimation values for cobia and other marine carnivorous fish species;

4- Evaluate growth performance, liver histopathology, and apparent digestibility coefficients for dry matter and crude protein, of cobia fed commercial and fishmeal-based diets partially replaced by alternative feedstuffs commercially available in the Brazilian market place. 


\subsection{Materials and Methods}

Field visits

In order to better understand the performance of cobia Rachycentron canadum culture in Brazil, one small-scale and one industrial-scale commercial cobia farm were visited, located in the city of Ubatuba and São Sebastião, respectively (Figure 1). The cities are situated in the North coast of São Paulo State (Southeastern Brazil), where the weather is humid sub-tropical, and the average water temperature is around $25^{\circ} \mathrm{C}$, ranging from a low of $19^{\circ} \mathrm{C}$ in the winter up to $30^{\circ} \mathrm{C}$ in the summer. Depth in the areas vary between 6 to $20 \mathrm{~m}$ and the sites are protected from the open sea. The anchoring system consisted of cables and concrete moorings, and it was built and installed by the farmers themselves. Routine management operations were performed using boats. Fish were fed a commercial extruded diet (45\% CP and 15\% lipids) twice daily. Floating cages were made by aluminum with wood (square) in the small-scale farm, and by highdensity polyethylene (circular) in the industrial-scale farm. Cages were stocked with 15-20 g cobia at a density of 3 fish $\mathrm{m}^{-3}$, and the fish were sold with 3-4 $\mathrm{kg}$ individual live weight. The duration of the nursery and grow-out phase were around 2 and 18 months, respectively (Figure 2).

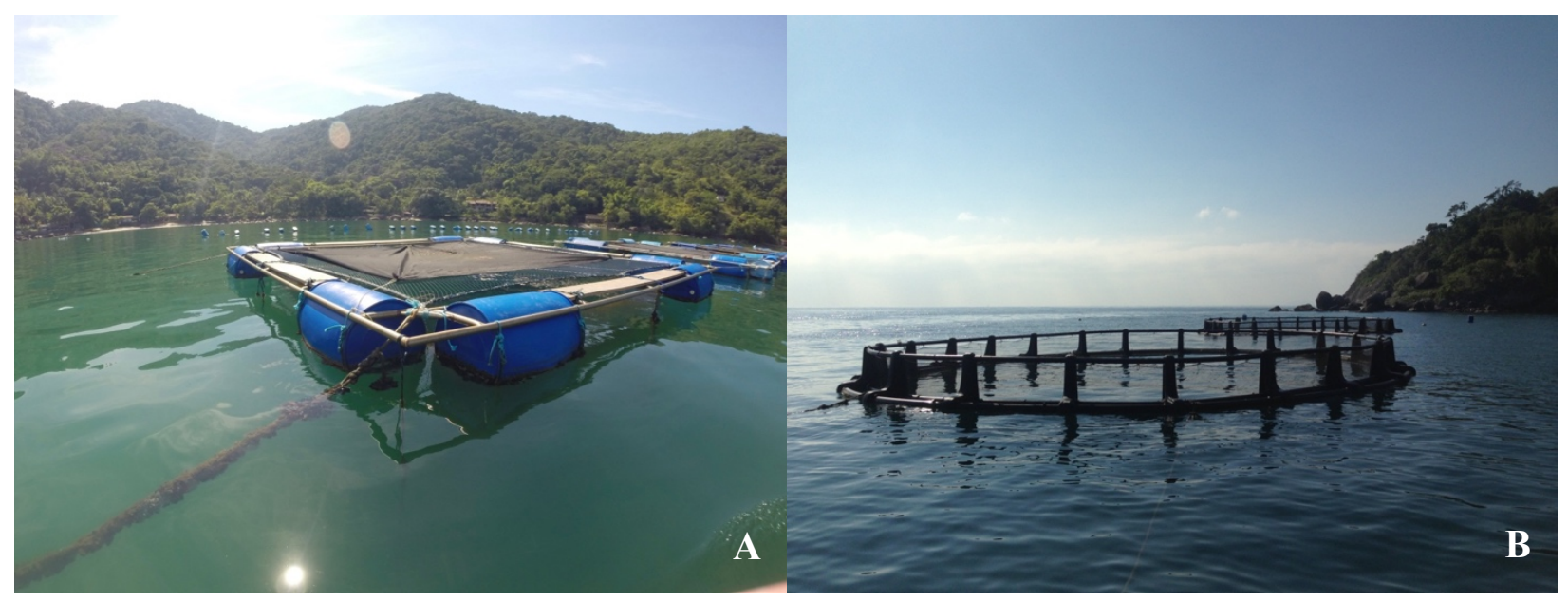

Figure 1 Commercial cobia Rachycentron canadum grow-out farms: Small-scale (A) and industrial-scale (B) commercial cobia farm visited during the field trips, located in the city of Ubatuba and São Sebastião, respectively. 


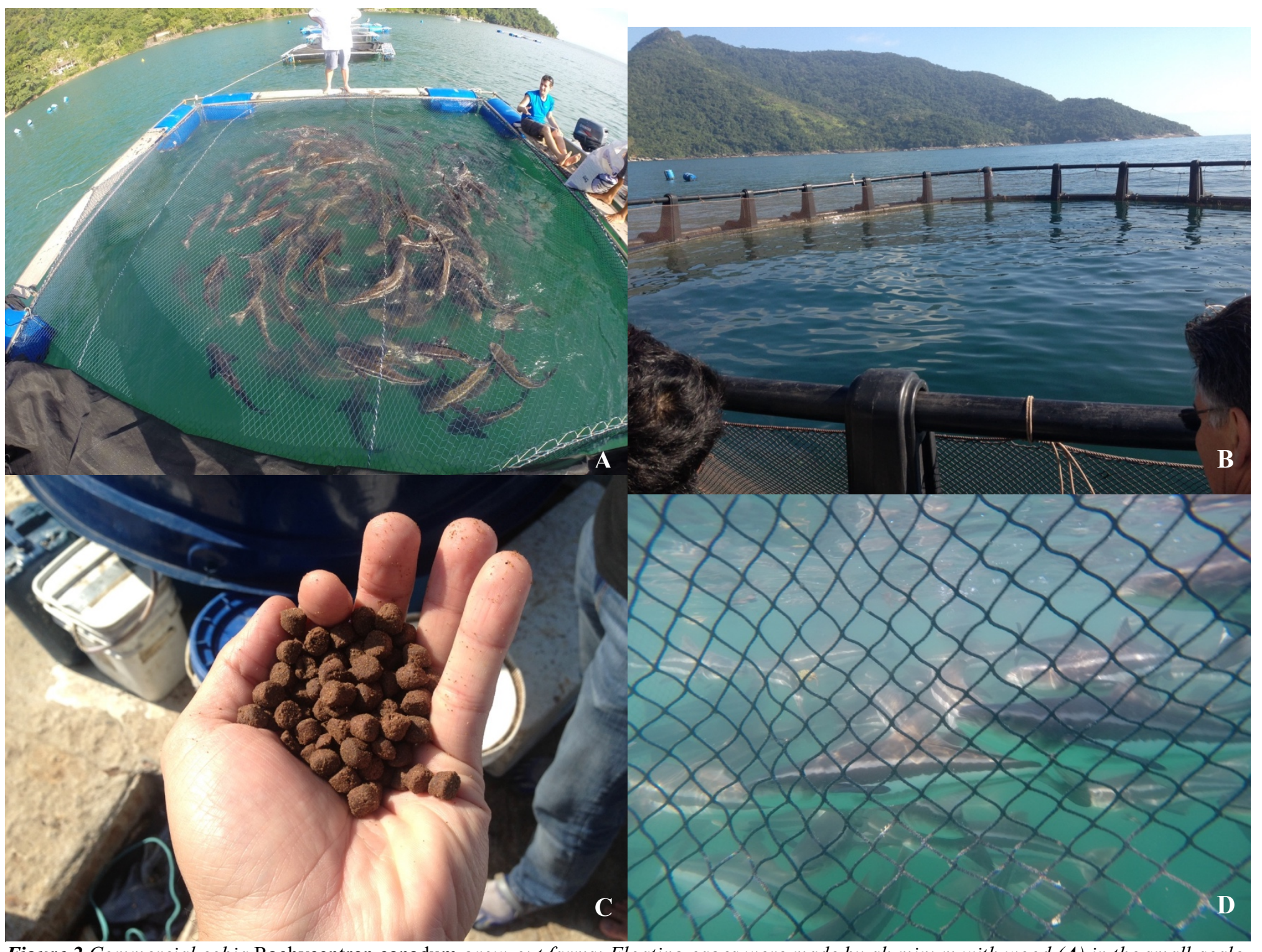

Figure 2 Commercial cobia Rachycentron canadum grow-out farms: Floating cages were made by aluminum with wood (A) in the small-scale farm, and by high-density polyethylene (B) in the industrial-scale farm. Fish were fed a commercial diet (45\% crude protein and $15 \%$ lipids) twice daily $(\boldsymbol{C})$. Fish were sold with 3-4 $\mathrm{kg}(\boldsymbol{D})$. 
Experimental animals and rearing

Approximately 2,000 juvenile of cobia Rachycentron canadum, initially weighting $6.0 \mathrm{~g}$ in average, were obtained from the commercial marine fish hatchery Redemar Alevinos, Ilhabela, SP, Brazil (Figure 3). The animals were submitted to 24 hours of fasting before being transported in plastic bags inflated with pure oxygen and then sealed. The suspension of feeding is critical in the preparation of fish for transport, because in the fasted state they consume less oxygen, excrete less ammonia and carbon dioxide and reduce the amount of feces excreted, contributing to maintaining the quality of water during transportation. Fish were housed in a 7,000 L open flow system tank (Figure 4), maintained at average temperature of $25^{\circ} \mathrm{C}$ and fed a $56 \%$ CP commercial feed (Fish Breed-M, INVE do Brasil Ltda, Fortaleza, CE, Brazil) four times a day until satiation, in order to reduce cannibalism. A maintenance diet (Table 1), with the same formulation (excluding chromic oxide) of the reference diet used in both feeding trials, was prepared and gradually added to de commercial diet, until total replacement. Cannibalism was observed only after 3 weeks of stocking. The water quality parameters (salinity, $\mathrm{pH}$, dissolved oxygen and temperature) were monitored daily (at about 08:00 am), using a YSI 85 ${ }^{\circledR}$ Meter (YSI Inc., Yellow Springs, USA). Acclimation and maintenance of the fishes occurred over the course of 3 months, prior to grading and stocking.

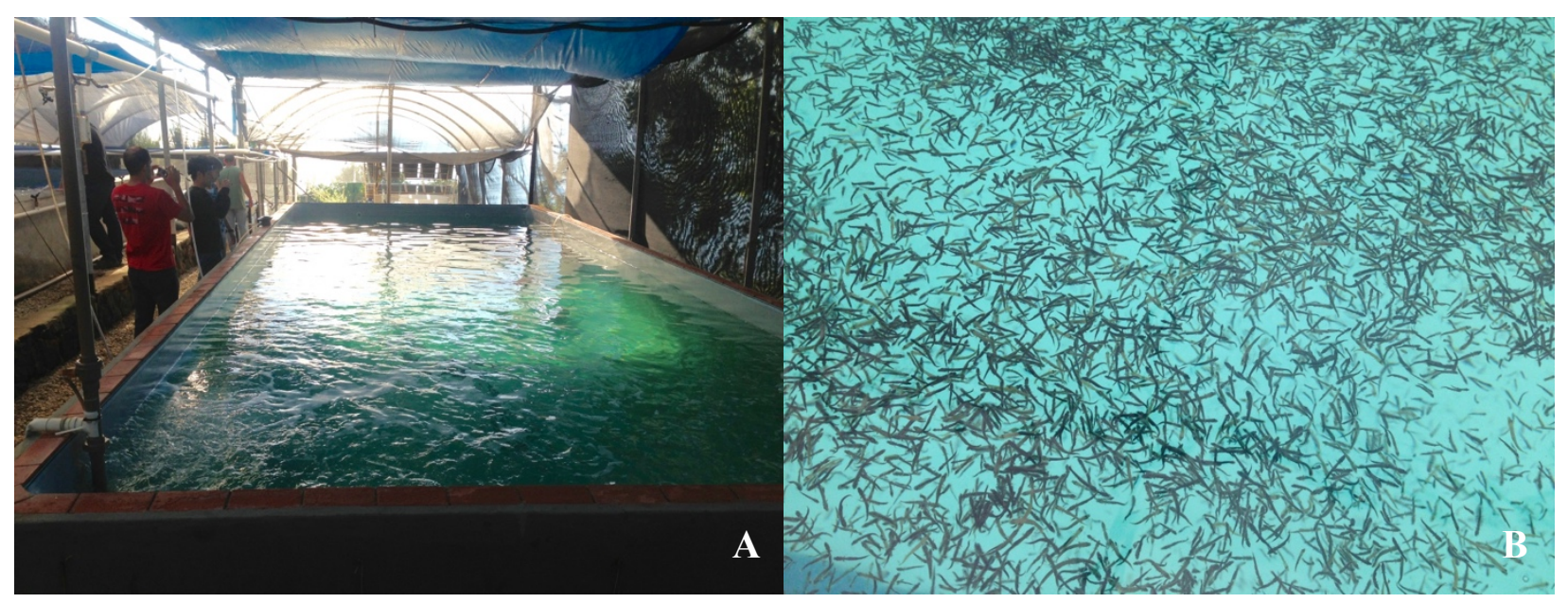

Figure 3 Commercial cobia Rachycentron canadum hatchery: Broodstock tank in the commercial marine fish hatchery Redemar Alevinos (A), fingerlings of cobia Rachycentron canadum (B). 
Table 1 - Formulation and proximate composition of maintenance diet used during the nursery phase for fingerling cobia Rachycentron canadum (\%, as is basis).

\begin{tabular}{ll}
\hline Ingredient & $\%$ \\
Fishmeal $^{1}$ & 50.0 \\
Poultry by product meal $^{1}$ & 10.5 \\
Squid meal $^{1}$ & 10.0 \\
Blood meal $^{1}$ & 3.0 \\
Wheat flour $^{1}$ & 10.0 \\
Wheat gluten $^{1}$ & 5.0 \\
Soy lecithin $^{1}$ & 1.0 \\
Fish oil $^{1}$ & 5.0 \\
Fish protein hydrolysate $^{2}$ & 4.0 \\
Vitamin and mineral premix $^{3}$ & 1.0 \\
Taurine $^{5}$ & 0.5 \\
Proximate composition $_{\text {Moisture }}$ & \\
Crude protein $_{\text {Crude fat }}$ & 6.7 \\
Fiber $^{\text {Ash }}$ & 48.1 \\
NFE & 12.1 \\
\hline
\end{tabular}

${ }^{1}$ Sourced by Guabi Nutrição animal, Campinas, SP, Brazil.

${ }^{2}$ Aquativ, Diana, Even, France.

${ }^{3}$ DSM, São Paulo, SP, Brazil.

${ }^{4}$ Sigma, St Louis, MO, USA.

${ }^{5}$ Sweetmix, Sorocaba, SP, Brazil.

${ }^{6}$ Nitrogen-free extract calculated by difference: 100 - moisture - crude protein - ash - crude fat - fiber.

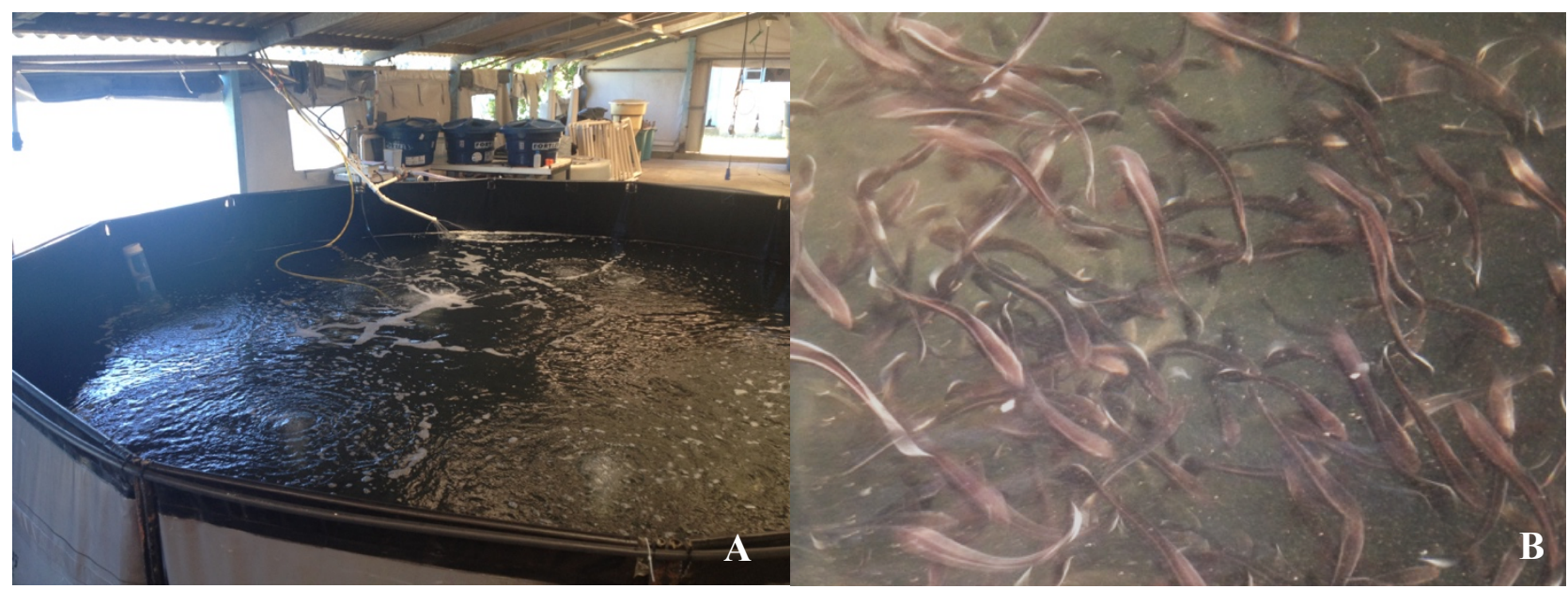

Figure 4 Cobia Rachycentron canadum nursery: Fish were housed in a 7,000 L open flow system tank (A). Acclimation and maintenance of the fishes occurred over the course of 3 months, prior to grading and stocking (B). 


\section{Experimental culture conditions}

Sea net-cage feeding trial

A new experimental system for commercial marine fish was developed to work at the Oceanographic Institute of the University of São Paulo, Ubatuba, Brazil (Figure 5). The objective of this system was to enable the conduct of research on marine fish species in experimental units approaching the maximum reality of local commercial cage producers.

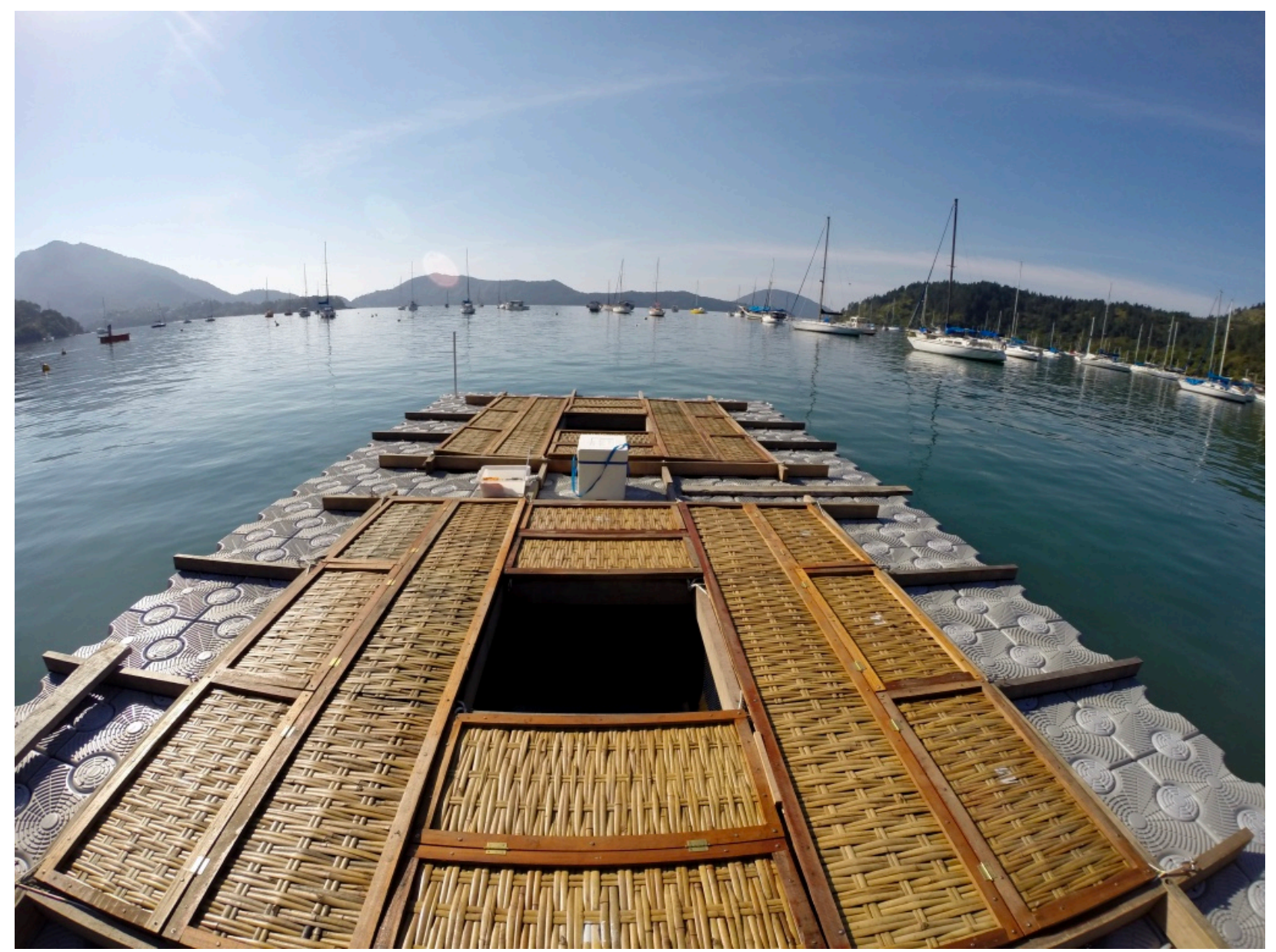

Figure 5 Sea cage net: experimental floating cage net system for marine fish located at the Oceanographic Institute, University of São Paulo, Ubatuba, Brazil.

A floating platform measuring $10.0 \mathrm{~m} \times 5.0 \mathrm{~m}$ was anchored about $90.0 \mathrm{~m}$ from the coast with an average depth of $3.0 \mathrm{~m}$. The platform was made of high-density polyethylene blocks, measuring 50.0 x 50.0 x $42.0 \mathrm{~cm}$ (Model Pierplas EVO, NTC Moldes e Plásticos, Caxias do Sul, 
RS, Brazil), and attached to each other by a plastic screw. It was mounted in rectangular format, leaving two spaces $(3.0 \mathrm{~m} \times 3.0 \mathrm{~m})$ inside, able to fit 16 net cages (Figure 6). The structure was moored with two concrete anchors of $500 \mathrm{~kg}$ each. A set of sixteen cages measuring $1.0 \mathrm{~m} \times 1.0$ $\mathrm{m} \times 1.3 \mathrm{~m}$, with nylon net of $8 \mathrm{~mm}$, composes the experimental system for commercial marine fish. The lids were made by a wooden structure, protecting the fishes against sunburns and natural predators (Figure 6). To hang the cages, it was developed two wooden frameworks that fits on the top of the platform (Figure 6). Each end of the cage net was attached on the wood framework by a stainless steel shackle. A PVC pipe frame filled with rocks was made to fit into the bottom of each cages, in order to keep net cubicle opened (Figure 7).

The routine transportation was done by kayak and a small boat, both equipped with paddles (Figure 7). The nets were exchanged and cleaned with a high-pressure washer every two weeks, to remove the fouling (Figure 7) and to repair when necessary. Feeds were transported within insulated plastic containers inside a thermal box, maintaining their integrity.

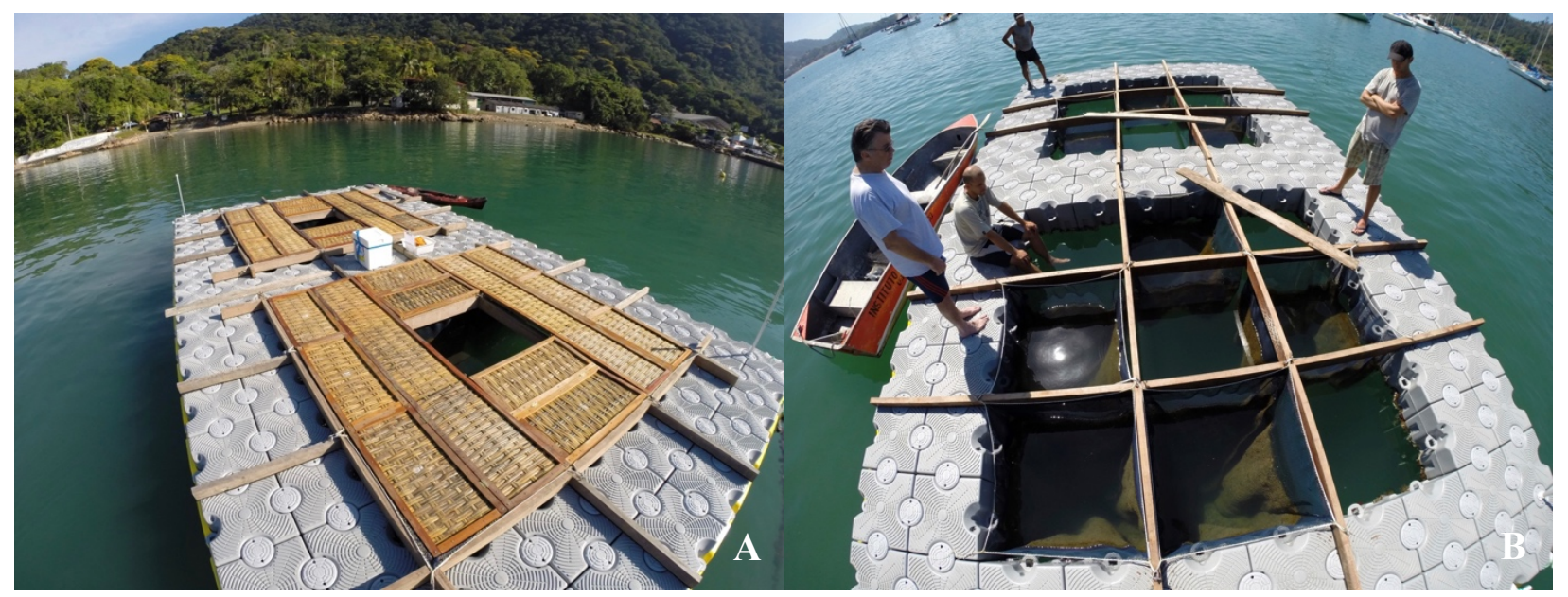

Figure 6 Sea cage net system: wooden framework developed to fit the cages and covers (A); lids made by a wooden structure, protecting the fishes against sunburns and natural predators $(\boldsymbol{B})$. 


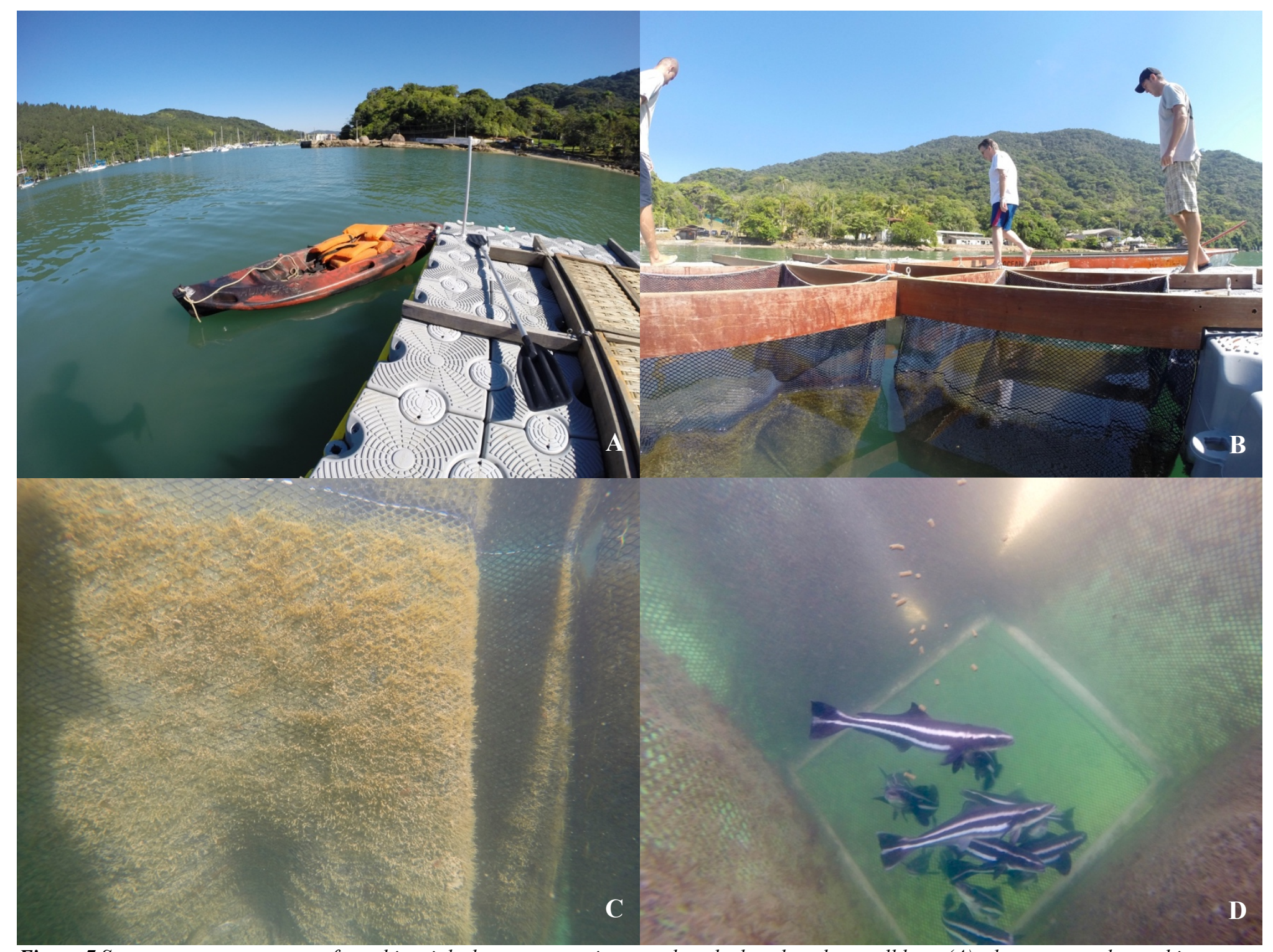

Figure 7 Sea cage net management for cobia trial: the transportation was done by kayak and a small boat (A); the nets were hanged in a wooden frameworks that fit on the top of the platform $(\boldsymbol{B})$; fouling was removed every two weeks $(\boldsymbol{C}) ;$ a PVC pipe frame was fitted into the bottom of each cages $(\boldsymbol{D})$. 


\section{Recirculated-tank based feeding trial}

A performance and digestibility feeding trial was also conducted at the Laboratory of Aquaculture of the Oceanography Institute, University of São Paulo, located in Ubatuba, SP, Brazil in a custom-designed, water-recirculating aquaculture system (RAS; Figure 8). The RAS was comprised of twenty-eight $500 \mathrm{~L}$ circular fiberglass tanks $(1.0 \mathrm{~m}$ of diameter with a conical bottom), biofilter with media for biological filtration and a side-looped protein skimmer to remove smaller solids and decrease turbidity. An immersion heater with a power of $1500 \mathrm{~W}$ with thermostats was placed in the header tank, in order to maintain water temperature at $28^{\circ} \mathrm{C}$. Supplemental aeration was provided to each tank to maintain dissolved oxygen levels near saturation. The water collected directly from the sea was stored in three tanks of 10,000 L each. Before entering the system, the water passed through a cartridge filter of 5 and $25 \mu \mathrm{m}$, and an ultraviolet filter and disinfected by UV before entering into tanks at a flow rate of $4 \mathrm{~L} \mathrm{~min}^{-1}$.

The system was operated as a closed water recirculation system and the water lost through evaporation and sampling, cleaning, and backwashing of filters, replaced as needed. Tanks were covered by a shading lid with natural illumination. Animals were acclimated during one week, and fed with the maintenance diet (Table 1) before the start of the feeding trial. 


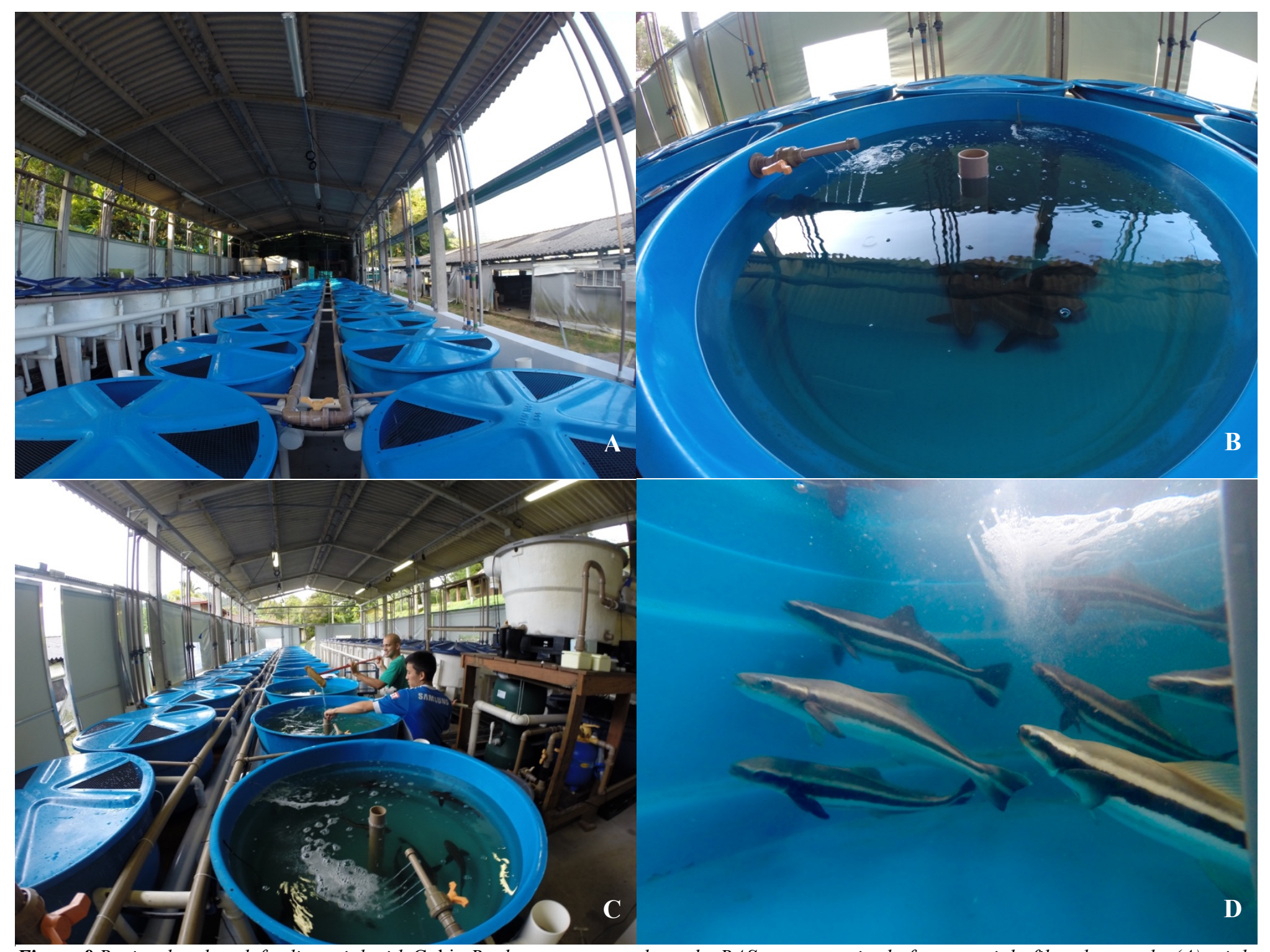

Figure 8 Recirculated-tank feeding trial with Cobia Rachycentron canadum: the RAS was comprised of twenty-eight fiberglass tanks (A); eight juvenile cobias were placed into each of the experimental tanks $(\boldsymbol{B})$; fish in each tank were weighed every two weeks to monitor growth performance $(\boldsymbol{C})$; animals were acclimated during one week, and fed with the maintenance diet $(\boldsymbol{D})$. 


\section{Diets and feeding protocols}

\section{Ingredients}

The main criteria used for ingredient selection was their market availability and current use within commercial aquaculture feeds in Brazil. The feed ingredients chosen included both animal and plant protein sources, including fishmeal [FM, national (Brazil) and imported (Chile)], poultry by-product meal, squid meal, blood meal, feather meal, soybean protein concentrate (SPC), wheat flour, and wheat gluten. The proximate and amino acid composition of the ingredients used are presented in Table 2.

Sea net-cage feeding trial diets

Three experimental diets and one commercial cobia feed were tested in the outdoor netcage feeding trial as follows:

1- Aquamar: experimental dry cold-pelleted diet,

2- SM: semi-moist diet composed of $60 \%$ of the diet Aquamar $+40 \%$ of trash-fish,

3- TF: trash-fish, composed by whole sardine Sardinella brasiliensis,

4- Commercial: locally available commercial extruded cobia feed (Matsuda Nutrição Animal, São Sebastião do Paraíso, MG, Brazil).

The ingredients used in the manufacture of the diet Aquamar were the same used for the maintenance diet (except chromic oxide), and their proximate and amino acid composition are presented in Table 2. The formulation and proximate chemical composition of the Aquamar diet is shown in Table 3. Fishmeal was used as the main source of dietary protein in the prepared diets. The micro ingredients (vitamin and mineral premix, chromic oxide, and taurine) were mixed in a portion of $0.5 \mathrm{~kg}$ of wheat flour and added to an industrial food mixer (Model ES600, Hobart Manufacturing Corporation, Troy, OH, USA) and mixed/homogenized for 10 minutes. Then, the macro ingredients (FM, squid meal, blood meal, poultry by-product meal, wheat flour, and wheat gluten) were added (totaling $20 \mathrm{~kg}$ ) and mixed for an additional 15 minutes (Figure 3). Finally, the liquid ingredients (fish oil, soy lecithin, fish hydrolysate, and approximately $25 \%$ of distilled water) were added, and the feed mixed for an additional 15 minutes. The Aquamar diet were prepared as $3 \mathrm{~mm}$-diameter pellets, and the internal (die) 
temperature of the pelleting was $37.5^{\circ} \mathrm{C}$ (Figure 9). The resulting moist pellets were then dried $\left(38^{\circ} \mathrm{C}\right)$ overnight in a drying cabinet using an air blower until the moisture level was $8.7 \%$. The pellets were placed in polypropylene bags and excess air was removed and then stored frozen ($\left.15^{\circ} \mathrm{C}\right)$ until fed. Chromic oxide $\left(\mathrm{Cr}_{2} \mathrm{O}_{3}\right)$ was used as an inert marker and was incorporated at $0.5 \%$. The semi-moist diet (SM) was prepared by mixing the Aquamar diet $(60 \%)$ with ground (2-mm) trash-fish (40\%), and then pelleting the mixture through a $5 \mathrm{~mm}$-diameter die plate (Figure 9). The resultant moist pellets were handily broken into smaller pieces $\left(\sim 0.5 \mathrm{~cm}^{3}\right)$, and then stored in plastic containers within a freezer until fed. The trash-fish (mainly sardine Sardinella brasiliensis) was bought fresh (average price of US\$0.50/kg) from commercial fishing boats, stored within a freezer, and then manually chopped $\left(\sim 1 \mathrm{~cm}^{2}\right)$ using a cleaver (Figure 9). Proximate composition of the diets are presented in Table 3. The commercial extruded feed (Matsuda Nutrição Animal, São Sebastião do Paraíso, MG, Brazil) was provided by a local commercial cobia farm (Maricultura Ilha de Buzios, São Sebastião, SP, Brazil). 


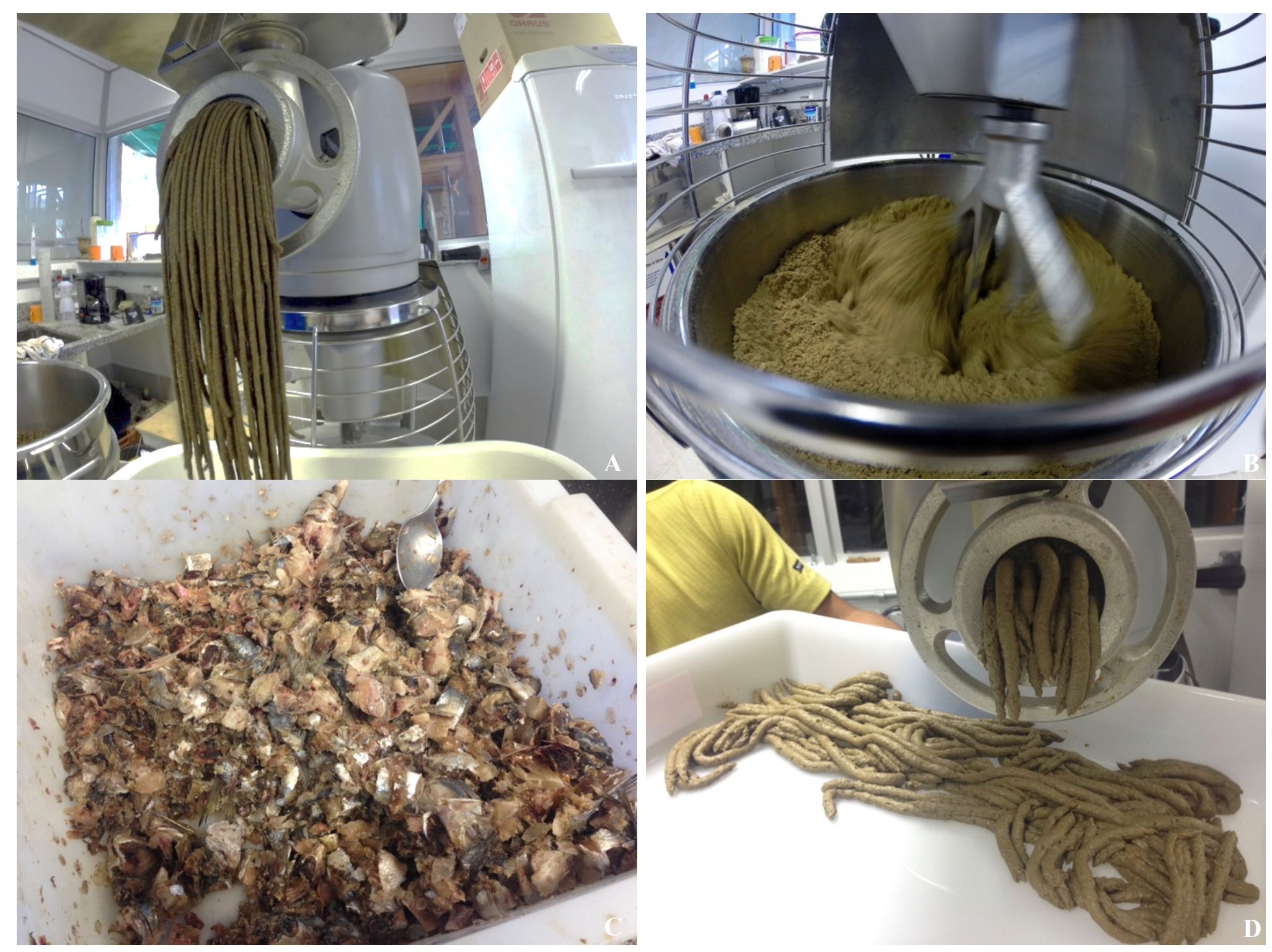

Figure 9 Feed preparation: ingredients were homogenized in an industrial food mixer (A); and cold-pelleted through a 3-mm die (B); trash-fish were bought from local fishing boats $(\boldsymbol{C})$; finished semi-moist feed prepared by mixing the Aquamar diet (60\%) with trash-fish (40\%)(D). 
Table 2 - Proximate and amino acid composition of the main ingredients used in the experimental diets for cobia Rachycentron canadum fed for 10 weeks (\%, as is basis).

\begin{tabular}{|c|c|c|c|c|c|c|c|c|c|}
\hline & $\begin{array}{l}\text { Fishmeal } \\
\text { (Brazilian) }^{1}\end{array}$ & $\begin{array}{l}\text { Fishmeal } \\
\text { (Chilean) }^{2}\end{array}$ & $\begin{array}{l}\text { Poultry by } \\
\text { product meal }^{2}\end{array}$ & $\begin{array}{l}\text { Squid } \\
\text { meal }^{2}\end{array}$ & $\begin{array}{l}\text { Blood } \\
\text { meal }^{2}\end{array}$ & $\begin{array}{l}\text { Feather } \\
\text { meal }^{2}\end{array}$ & $\begin{array}{l}\text { Wheat } \\
\text { flour }^{2}\end{array}$ & $\begin{array}{l}\text { Wheat } \\
\text { gluten }\end{array}$ & $\begin{array}{l}\text { Soy protein } \\
\text { concentrate }^{3}\end{array}$ \\
\hline \multicolumn{10}{|c|}{ Proximate composition } \\
\hline Moisture & 8.57 & 10.13 & 4.99 & 3.66 & 2.43 & 3.96 & 10.38 & 8.88 & 6.53 \\
\hline Crude protein & 59.20 & 65.82 & 49.59 & 86.56 & 98.91 & 85.34 & 14.50 & 77.84 & 61.72 \\
\hline Crude fat & 11.37 & 8.36 & 17.47 & 4.86 & 1.53 & 9.67 & 2.59 & 4.91 & 2.65 \\
\hline Crude fiber & 0.50 & 0.50 & 0.66 & 1.75 & 0.50 & 0.50 & 0.69 & 0.50 & 3.63 \\
\hline Ash & 16.68 & 16.22 & 26.74 & 3.66 & 1.79 & 3.04 & 1.18 & 0.87 & 6.62 \\
\hline $\mathrm{NFE}^{4}$ & 3.68 & 0.00 & 0.55 & 0.00 & 0.00 & 0.00 & 70.66 & 7.00 & 18.85 \\
\hline Calcium (Ca) & 3.96 & 4.21 & 4.96 & 0.07 & 0.07 & 0.62 & 0.03 & 0.07 & 0.28 \\
\hline Phosphorus (P) & 2.76 & 2.55 & 2.47 & 0.67 & 0.09 & 0.46 & 0.27 & 0.21 & 0.67 \\
\hline \multicolumn{10}{|c|}{ Essential amino acids } \\
\hline Arginine & 3.16 & 3.69 & 3.04 & 5.89 & 5.80 & 5.67 & 0.60 & 2.47 & 3.88 \\
\hline Histidine & 2.05 & 1.23 & 0.72 & 1.94 & 5.10 & 1.06 & 0.33 & 1.43 & 1.49 \\
\hline Isoleucine & 2.03 & 1.96 & 1.57 & 3.23 & 3.60 & 3.52 & 0.50 & 2.40 & 2.48 \\
\hline Leucine & 3.79 & 3.76 & 3.13 & 6.40 & 10.40 & 7.20 & 0.94 & 4.80 & 4.58 \\
\hline Lysine & 4.20 & 4.17 & 2.27 & 7.08 & 8.30 & 2.70 & 0.36 & 1.24 & 3.72 \\
\hline Methionine & 1.40 & 1.61 & 0.78 & 2.42 & 0.73 & 3.90 & 0.17 & 1.00 & 0.40 \\
\hline Phenylalanine & 1.84 & 1.89 & 1.61 & 2.87 & 3.90 & 3.81 & 0.61 & 3.35 & 2.76 \\
\hline Threonine & 2.24 & 2.43 & 1.58 & 3.35 & 3.80 & 3.75 & 0.36 & 1.63 & 2.01 \\
\hline Tryptophan & - & - & - & - & - & - & - & - & - \\
\hline Valine & 2.19 & 2.25 & 2.06 & 3.05 & 6.70 & 5.55 & 0.54 & 2.34 & 2.34 \\
\hline Taurine & 0.46 & 0.76 & 0.09 & 0.46 & 0.12 & 0.12 & 0.00 & 0.00 & 0.00 \\
\hline \multicolumn{10}{|c|}{ Non-essential amino acids } \\
\hline Cystine & 0.61 & 0.57 & 1.19 & 1.48 & 0.81 & 5.90 & 0.29 & 2.64 & 0.80 \\
\hline Tyrosine & 1.38 & 1.38 & 1.01 & 2.67 & 2.70 & 2.61 & 0.19 & 1.90 & 1.41 \\
\hline Serine & 1.94 & 2.39 & 2.27 & 3.39 & 4.90 & 8.70 & 0.62 & 3.18 & 2.81 \\
\hline Aspartic Acid & 3.73 & 4.25 & 1.35 & 7.53 & 5.56 & 5.44 & 0.63 & 1.91 & 5.86 \\
\hline Glutamic Acid & 6.98 & 7.89 & 4.65 & 12.60 & 8.60 & 9.40 & 4.89 & 31.90 & 11.52 \\
\hline Proline & 2.69 & 3.44 & 3.65 & 3.83 & 3.57 & 7.41 & 1.55 & 9.23 & 2.99 \\
\hline Alanine & 3.41 & 2.90 & 2.94 & 4.52 & 6.10 & 4.01 & 0.48 & 1.77 & 2.36 \\
\hline
\end{tabular}

Data are mean values $(n=2)$.

${ }^{1}$ Residue meal from fish processing (sardine Sardinella brasiliensis), Indústrias Alimentícias Leal Santos Ltda, Rio Grande, RS.

${ }^{2}$ Sourced by Guabi Nutrição animal, Campinas, SP, Brazil.

${ }^{3}$ Sementes Selecta Ltda, Araguari, MG.

${ }^{4}$ Nitrogen-free extract calculated by difference: 100 - moisture - crude protein - ash - crude fat - fiber.

Dash indicates not determined. 
Table 3 - Formulation and proximate composition of the experimental and commercial feeds for cobia Rachycentron canadum fed for 10 weeks.

\begin{tabular}{|c|c|c|c|c|}
\hline \multirow[b]{2}{*}{ Ingredient $(\%)$} & \multicolumn{4}{|c|}{ Diet } \\
\hline & Aquamar $^{1}$ & Semi-moist ${ }^{2}$ & $\begin{array}{l}\text { Trash- } \\
\text { fish }^{3}\end{array}$ & Commercial $^{4}$ \\
\hline Fishmeal (Brazilian) ${ }^{5}$ & 50.0 & - & - & - \\
\hline Poultry meal ${ }^{5}$ & 10.0 & - & - & - \\
\hline Squid meal ${ }^{5}$ & 10.0 & - & - & - \\
\hline Blood meal $^{5}$ & 3.0 & - & - & - \\
\hline Wheat flour ${ }^{5}$ & 10.0 & - & - & - \\
\hline Wheat gluten $^{5}$ & 5.0 & - & - & - \\
\hline Fish oil ${ }^{5}$ & 5.0 & - & - & - \\
\hline Fish hydrolysate ${ }^{6}$ & 4.0 & - & - & - \\
\hline Soybean lecithin oil ${ }^{5}$ & 1.0 & - & - & - \\
\hline Mineral and vitamin premix ${ }^{7}$ & 1.0 & - & - & - \\
\hline $\mathrm{Cr}_{2} \mathrm{O}_{3}^{8}$ & 0.5 & - & - & - \\
\hline Taurine $^{9}$ & 0.5 & - & - & - \\
\hline \multicolumn{5}{|c|}{ Proximate composition (\% as is basis) } \\
\hline Moisture & 8.7 & 32.8 & 69.0 & 5.3 \\
\hline Crude protein & 52.3 & 38.7 & 18.9 & 41.5 \\
\hline Crude lipid & 15.8 & 13.6 & 4.1 & 18.5 \\
\hline Crude fiber & 0.5 & 0.1 & 0.0 & 0.8 \\
\hline Ash & 11.3 & 8.8 & 3.9 & 8.4 \\
\hline $\mathrm{NFE}^{10}$ & 11.4 & 5.9 & 4.4 & 30.7 \\
\hline Calcium $(\mathrm{Ca})$ & 4.0 & $\mathrm{na}^{11}$ & na & 2.1 \\
\hline Phosphorus (P) & 2.4 & na & na & 1.2 \\
\hline Gross energy $\left(\mathrm{MJ} \mathrm{kg}^{-1}\right)$ & 4875.6 & 3713.1 & 1743.8 & na \\
\hline \multicolumn{5}{|l|}{ Marker } \\
\hline $\mathrm{Cr}_{2} \mathrm{O}_{3}$ & 0.46 & 0.21 & - & - \\
\hline
\end{tabular}

\footnotetext{
${ }^{1}$ Experimental dry cold-pelleted diet

${ }^{2}$ Semi moist diet; frozen trash fish: diet Aquamar (40:60 misture, w/w).

${ }^{3}$ Frozen fish; mainly sardine Sardinella brasiliensis.

${ }^{4}$ Cobia extruded commercial diet (Matsuda Nutrição Animal, São Sebastião do Paraíso, MG, Brazil).

${ }^{5}$ Sourced by Guabi Nutrição animal, Campinas, SP, Brazil.

${ }^{6}$ Aquativ, Diana, Even, France.

${ }^{7}$ DSM, São Paulo, SP - consisted of (mg/kg premix) the following: ascorbic acid, 250.0; DL-calcium pantothenate 125.0; choline chloride, 750.0; inositol, 400.0; folic acid 6.0; biotin, 0.6; niacin, 100; vitamin A (6000 UI/kg), ; vitamin D3 (2000 UI/kg), ; vitamin E, 350.0; vitamin K3, 5.0; vitamin B1, 35.0; vitamin B2, 25.0; vitamin B6, 35.0; vitamin $\mathrm{B} 12,0.1$; Se, 0.5; Cr, 0.5; Iron, 100.0; Cu, 10.0; Zinc, 150.0; Mg, 25.0; Iodine, 3.0; Cobalt, 0.5 .

${ }^{8}$ Sigma, St Louis, MO, USA.

${ }^{9}$ Sweetmix, Sorocaba, SP, Brazil.

${ }^{10}$ Nitrogen-free extract calculated by difference: 100 - moisture - crude protein - ash - crude lipid - fiber.

${ }^{11}$ na: not analyzed.

Data are means for 3 replicates.

Dash indicates not determined.
} 
Recirculating-water tanks feeding trial diets

Fishmeal-based control diet (AM1-NFM) - similar to commercial cobia diets (in regard of CP and lipid contents) - was formulated to contain 50\% CP from national FM (residue meal from fish processing, sardine Sardinella brasiliensis), poultry by-product meal, squid meal, blood meal, wheat flour, and wheat gluten, which was also used to provide starch-related binding. Fish oil and soybean lecithin were included as lipid sources and provided in combination with FM a total of $17 \%$ total lipid. Five experimental diets were derived from the control diet by replacing FM protein with locally available protein sources, while maintaining diets iso-nitrogenous and iso-lipidic. The six experimental diets, including a commercial cobia extruded feed, tested in the recirculating-water tank were as follows:

1- AM1-NFM: national FM (Brazilian),

2- $\quad$ AM2-CFM: imported FM (Chilean),

3- AM3-PBM: national poultry by-product meal,

4- $\quad$ AM4-SPC: national soy protein concentrate (SPC),

5- AM5-PBF: national poultry by-product meal + feather meal,

6- $\quad$ AM6-TAU: control diet (AM1-NFM) without taurine supplementation (0.5\%),

7- Commercial: national commercial extruded cobia feed (Matsuda Nutrição Animal, São Sebastião do Paraíso, MG, Brazil).

The formulations and compositions of the six experimental diets and one commercial feed are shown in Table 4. Both diets AM4-SPC and AM5-PBF were supplemented with DLmethionine and lysine (Evonik Degussa GmbH, Hanau, Germany). Also, dicalcium phosphate was added (1.5\%) to diet AM4-SPC as an additional source of dietary phosphorus. Chromic oxide $\left(\mathrm{Cr}_{2} \mathrm{O}_{3}\right)$ was included at $0.5 \%$ within all the experimental diets as an inert indigestible marker. The diets were prepared as described previously for the Aquamar diet (sea net-cage trial). 
Table 4 - Formulation and proximate composition of the six experimental diets and one commercial feed for cobia Rachycentron canadum fed for 10 weeks.

\begin{tabular}{|c|c|c|c|c|c|c|c|}
\hline \multirow{2}{*}{ Ingredient (\%) } & \multicolumn{7}{|c|}{ Diet } \\
\hline & AM1-NFM & AM2-CFM & AM3-PBM & AM4-SPC & AM5-PBF & AM6-TAU & Commercial \\
\hline Fishmeal (Brazilian) $^{1}$ & 50.0 & - & 25.0 & 25.0 & 25.0 & 50.0 & - \\
\hline Fishmeal (Chilean) ${ }^{2}$ & - & 45.0 & - & - & - & - & - \\
\hline Poultry by product meal ${ }^{2}$ & 10.0 & 11.0 & 36.0 & 11.2 & 23.0 & 10.0 & - \\
\hline Squid meal ${ }^{2}$ & 10.0 & 10.0 & 10.0 & 10.0 & 10.0 & 10.0 & - \\
\hline Blood meal $^{2}$ & 3.0 & 2.0 & 5.0 & 3.0 & 4.0 & 3.0 & - \\
\hline Feather meal $^{2}$ & - & - & & - & 7.0 & - & - \\
\hline Wheat flour ${ }^{2}$ & 10.2 & 12.2 & 7.3 & 7.4 & 12.7 & 10.7 & - \\
\hline Wheat gluten ${ }^{2}$ & 5.0 & 5.0 & 5.0 & 5.0 & 5.0 & 5.0 & - \\
\hline Soy protein concentrate ${ }^{3}$ & - & - & - & 21.0 & - & - & - \\
\hline Dicalcium phosphate $^{2}$ & - & - & - & 1.5 & - & - & - \\
\hline Fish oil $^{2}$ & 4.8 & 7.8 & 4.7 & 8.1 & 5.7 & 4.8 & - \\
\hline Fish hydrolysate ${ }^{4}$ & 4.0 & 4.0 & 4.0 & 4.0 & 4.0 & 4.0 & - \\
\hline Soybean lecithin oil ${ }^{2}$ & 1.0 & 1.0 & 1.0 & 1.0 & 1.0 & 1.0 & - \\
\hline Mineral and vitamin premix ${ }^{5}$ & 1.0 & 1.0 & 1.0 & 1.0 & 1.0 & 1.0 & - \\
\hline $\mathrm{Cr}_{2} \mathrm{O}_{3}{ }^{6}$ & 0.5 & 0.5 & 0.5 & 0.5 & 0.5 & 0.5 & - \\
\hline Taurine $^{7}$ & 0.5 & 0.5 & 0.5 & 0.5 & 0.5 & - & - \\
\hline DL-methionine $^{8}$ & - & - & - & 0.6 & 0.3 & - & - \\
\hline Lysine $^{8}$ & - & - & - & 0.2 & 0.3 & - & - \\
\hline \multicolumn{8}{|c|}{ Proximate composition (\%, as is basis) } \\
\hline Moisture & 5.5 & 6.4 & 7.6 & 4.7 & 5.4 & 4.5 & 5.3 \\
\hline Crude protein & 50.7 & 51.1 & 50.1 & 48.6 & 49.4 & 50.0 & 41.5 \\
\hline Crude fat & 17.0 & 17.0 & 18.0 & 11.0 & 16.9 & 16.9 & 18.5 \\
\hline Ash & 16.6 & 12.1 & 17.2 & 13.8 & 15.0 & 17.3 & 8.4 \\
\hline $\mathrm{NFE}^{9}$ & - & - & - & - & - & - & 30.74 \\
\hline \multicolumn{8}{|l|}{ Marker } \\
\hline $\mathrm{Cr}_{2} \mathrm{O}_{3}$ & 0.45 & 0.45 & 0.42 & 0.46 & 0.45 & 0.45 & - \\
\hline
\end{tabular}

${ }^{1}$ Residue meal from fish processing (sardine Sardinella braziliensis), Indústrias Alimentícias Leal Santos Ltda, Rio Grande, RS.

${ }^{2}$ Sourced by Guabi Nutrição Animal Ltda, Campinas, SP.

${ }^{3}$ Sementes Selecta Ltda, Araguari, MG.

${ }^{4}$ Spécialités Pet Food SAS, Elven, France.

${ }^{5}$ DSM, São Paulo, SP - consisted of (mg/kg premix) the following: ascorbic acid, 250.0; DL-calcium pantothenate 125.0; choline chloride, 750.0; inositol, 400.0; folic acid 6.0; biotin, 0.6; niacin, 100; vitamin A (6000 UI/kg),

vitamin D3 (2000 UI/kg), ; vitamin E, 350.0; vitamin K3, 5.0; vitamin B1, 35.0; vitamin B2, 25.0; vitamin B6, 35.0; vitamin B12, 0.1; Se, 0.5; Cr, 0.5; Iron, 100.0; Cu, 10.0; Zinc, 150.0; Mg, 25.0; Iodine, 3.0; Cobalt, 0.5.

${ }^{6}$ Sigma, St Louis, MO, USA.

'Sweetmix, Sorocaba, SP, Brazil.

${ }^{8}$ Evonik Degussa GmbH, Hanau, Germany.

Nitrogen-free extract calculated by difference: 100 - moisture - crude protein - ash - crude fat - fiber.

Data are mean for 3 replicates.

Dash indicates not determined or zero if not present. 
Sea net-cage feeding trial protocol

Fifteen fish (127.74 $\pm 10.84 \mathrm{~g}$ initial body weight) were randomly distributed into 12 experimental cages (Figure 6). The initial density corresponded to $1.9 \mathrm{~kg} / \mathrm{m}^{3}$. There were 3 replicates per dietary treatment. Diets were transported to the cages each day within insulated plastic containers, and the containers for individual cages then weighed on a top-pan balance before and after feeding. Animals were hand-fed seven days per week, two times per day, at 09:00 and 16:00 $\mathrm{h}$ until apparent satiation, without overfeeding (Figure 10). Since the experimental diets sinks, the duration of the feeding routine was around 1:00 hour, in order for one person to feed all the 12 net-cages. Fish were weighed at the start of the experiment and at successive biweekly intervals for the duration of the feeding trial (10 weeks). The weighing process was done on the top of the floating platform, with animals being weighed wet in groups using a $20 \mathrm{~L}$ bucket filled with seawater and a scale powered by a car battery. Fish mortalities were recorded whenever apparent. For carcass comparison analysis, fish were collected at the start of the experiments (from a representative population sample) and from each tank at the end of the feeding trial (5 fish per cage) and frozen for subsequent analysis on an individual cage basis.

Recirculating-water tank feeding trial protocol

After the acclimation period, eight juvenile individuals $(88.7 \pm 1.3 \mathrm{~g})$ were randomly placed into each of 28 experimental tanks, at an initial density of $1.75 \mathrm{~kg} / \mathrm{m}^{3}$ (Figure 11). Tanks were arbitrarily assigned to one of seven diets ( $\mathrm{n}=4$ replicate tanks/diet) and animals were handfed two times per day, at 09:00 and 16:00 h until apparent satiation, without overfeeding. All experimental animals were weighed at bi-weekly intervals for the duration of the experiment (70-day). Fish were weighed wet using a $20 \mathrm{~L}$ bucket, and an analytical balance $(0.01 \mathrm{~g})$. 


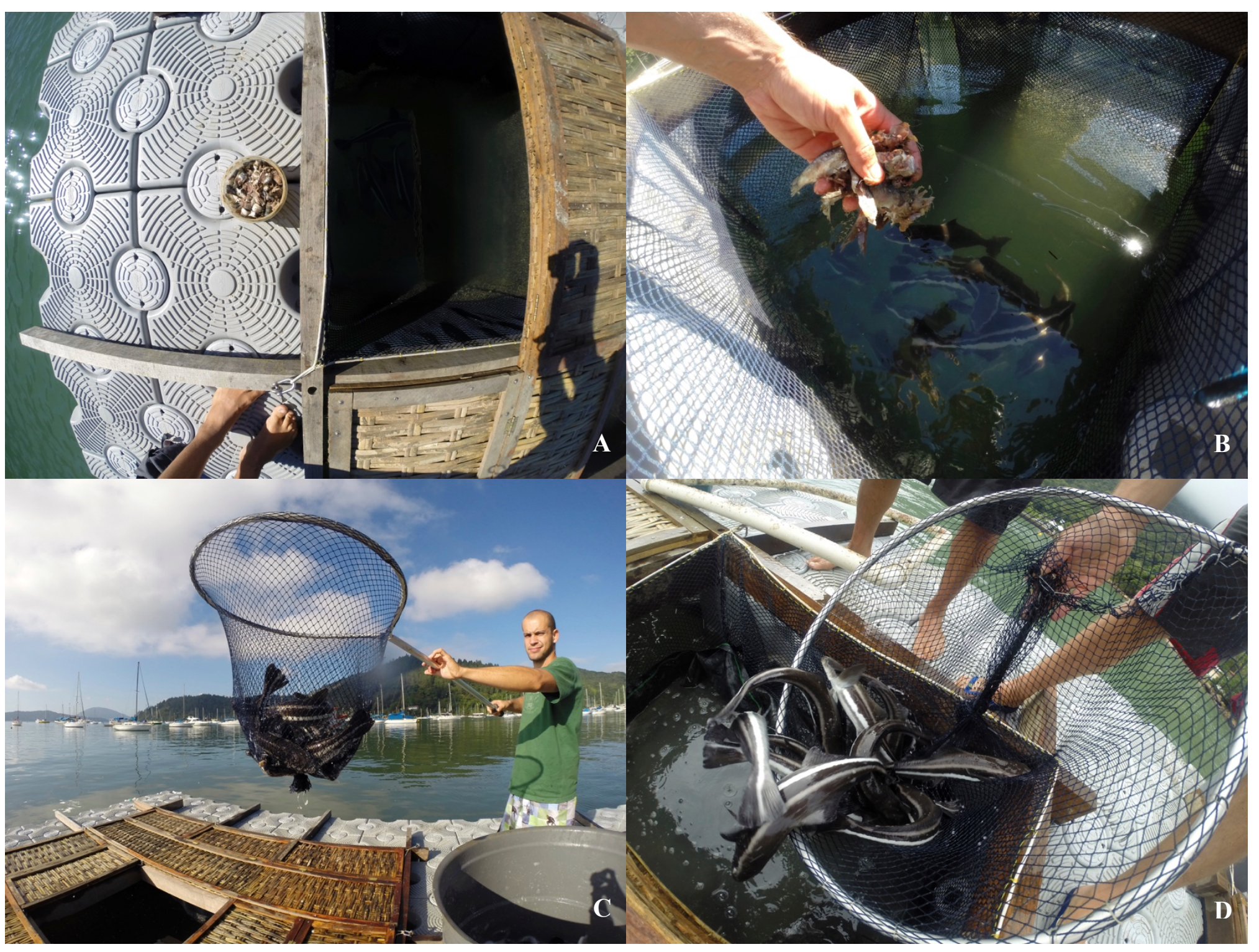

Figure 10 Cobia Rachycentron canadum sea cage feeding trial protocols: diets were transported within insulated plastic containers (A); fish were hand-fed two times per day, at 09:00 and 16:00 $\mathrm{h}(\boldsymbol{B})$; the weighing process was done on the top of the floating platform (C); animals were weighed in group $(\boldsymbol{D})$. 
Fish performance calculations

Experimental net-cages and indoor tanks of both feeding trials were evaluated after 10 weeks. Fish were anesthetized using clove oil $(1.0 \mathrm{ml} / \mathrm{L}$ ), and then weighed individually (Figure 10; 11). Feed and fish performance was evaluated using the following biometrics:

Initial body weight $(\mathrm{g})=$ (initial total mass of tank weight / number of fish),

Final body weight $(\mathrm{g})=($ final total mass of tank weight / number of fish $)$,

Weight gain $(\%)=($ final fish biomass $(\mathrm{g})$ - initial shrimp biomass $(\mathrm{g})) /$ initial fish biomass $(\mathrm{g}) * 100$,

SGR - specific growth rate $=(\ln$ final weight $-\ln$ initial weight $) /$ days $* 100$,

FCR - feed conversion ratio $=$ total feed offered $(\mathrm{g}$, as fed $) /[$ final fish biomass $(\mathrm{g})-$ initial fish biomass $(\mathrm{g})]$,

PER - protein efficiency ratio $=[$ final fish biomass $(\mathrm{g})-$ initial fish biomass $(\mathrm{g})]$ / grams protein fed (dry matter basis),

Survival $(\%)=($ final number of fish $/$ initial number of fish $) * 100$.

Feces collection

After the 10-week performance period, there was scheduled a fecal stripping routine for all treatments, in order to obtain feces samples sufficient for proximate and marker analysis. Each cage and tank was sampled every two days (total of four times) over a two-week period. Fish were fed their respective diets to apparent satiety as determined by the loss of feeding activity, 5 hours before (8:00 to 9:00 am) the feces collection. Feces were then collected the following afternoon (2:00 PM) from each fish within each tank using stripping techniques based on those reported by GLENCROSS (2011). Fish were anesthetized using clove oil (1.0 ml/L). Once loss of equilibrium by the fish was observed (around 1 minute), close attention was then paid to the relaxation of the ventral abdominal muscles of the fish to enable the fish to be 
removed from the water prior to the fecal matter being expelled. The feces were then removed from the distal intestine using gentle abdominal pressure during this muscle relaxation (Figure 12). Hands were rinsed between handling each fish to ensure that the feces were not contaminated by urine or mucous. Fish were not stripped on consecutive days in order to minimize stress on the animal (as determined by loss of appetite and physical damage, of which none was observed) and maximize feed intake prior to fecal collection. Around $200 \mathrm{~g}$ of wet feces were collected from each cage/tank, in order to guarantee a minimum amount of dry samples enough for the analyses. Fecal samples from different days were pooled within tanks and kept frozen at $-15^{\circ} \mathrm{C}$. Samples were oven-dried at $60^{\circ} \mathrm{C}$ and analyzed for proximal composition (dry matter, crude protein and ash) and inert marker $\left(\mathrm{Cr}_{2} \mathrm{O}_{3}\right)$.

\section{Liver histopathology and visual body cavity examination}

At the end of the fecal collection period, 4 fish were taken from each replicate cage and tank, culled in ice with water and then enumerated. Hepatosomatic index [HIS - (liver weight / body weight) * 100] was calculated from each fish, and the same liver was used for the histopathology analysis. Two fragments of each organ $\left(0.5 \mathrm{~cm}^{3}\right)$ were cut and sectioned by first placing the tissue in a $15 \mathrm{ml}$ ambar glass vial contaning Bouin's fixative solution. Bouin's solution was prepared by mixing $75 \mathrm{ml}$ of saturated aqueous picric acid, $25 \mathrm{ml}$ of formalin, and 5 $\mathrm{ml}$ of glacial acetic acid. The tissues were fixed in Bouin's solution overnight, then washed 3 times with $70 \%$ ethanol until most of the yellow color was removed from the tissues. Liver samples were subjected to histological processing with inclusion in Paraplast, sectioned into $5 \mu \mathrm{m}$ thick sections and stained with hematoxylin-eosin (H\&E). Histological sections were observed and examined under a light microscope (model Olympus IX73, Olympus Inc., Tokyo, Japan), and the images captured using a digital camera Eurekam 3.0 with software Bel View 7 (BEL Engineering srl, Monza, Italia). Pictures from the body cavity of each fish were also taken for visual inspection of fat accumulation, organ coloration and general morphology (Figure 11). 


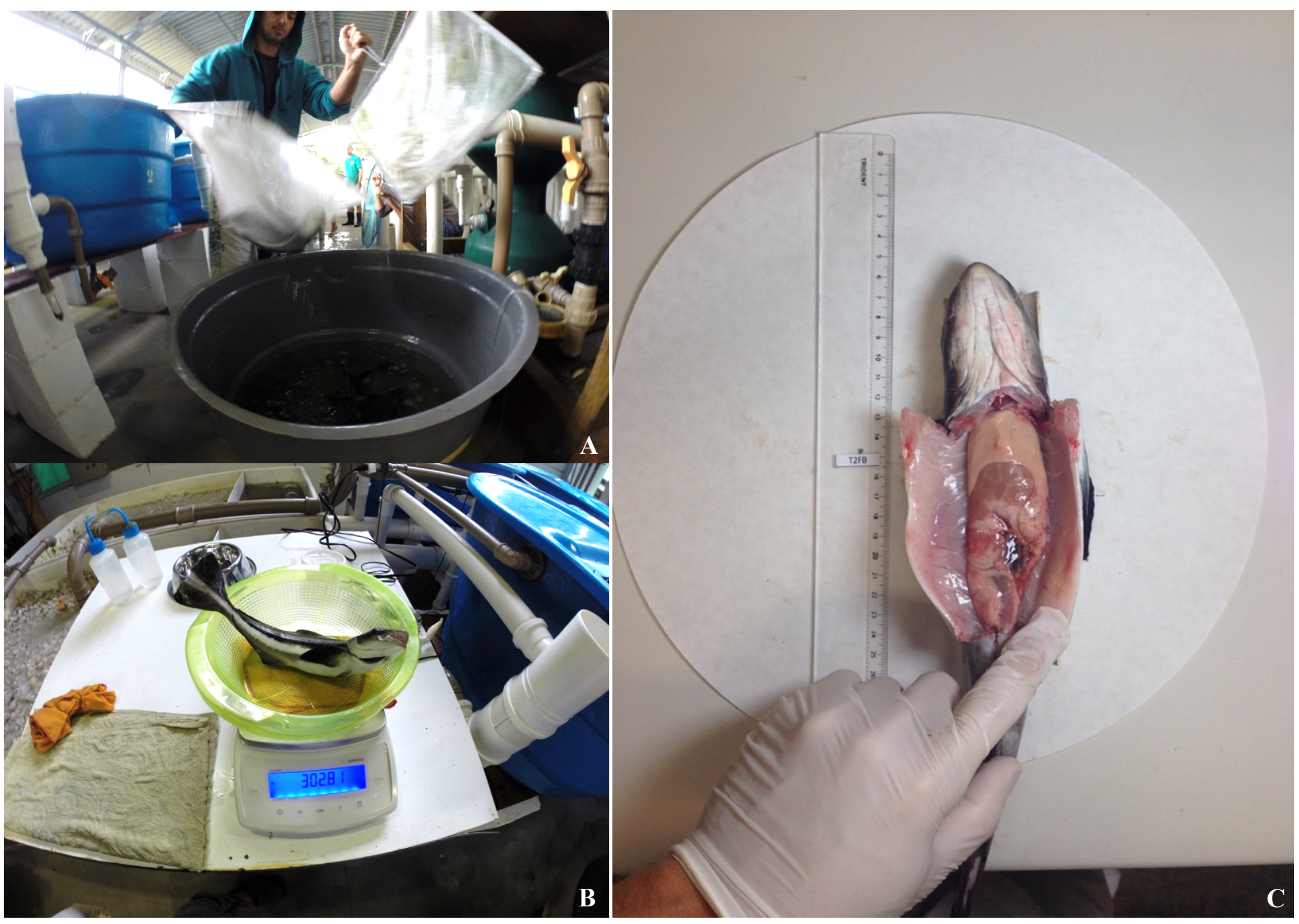

Figure 11 Recirculated-water tanks feeding trial protocols: fish were anesthetized using clove oil, and then weighed individually by treatment tank (A); feces were collected from each fish within each tank using stripping techniques (B); pictures from the body cavity of each fish were taken for visual analysis of organ coloration, and fat accumulation $(\boldsymbol{C})$. 


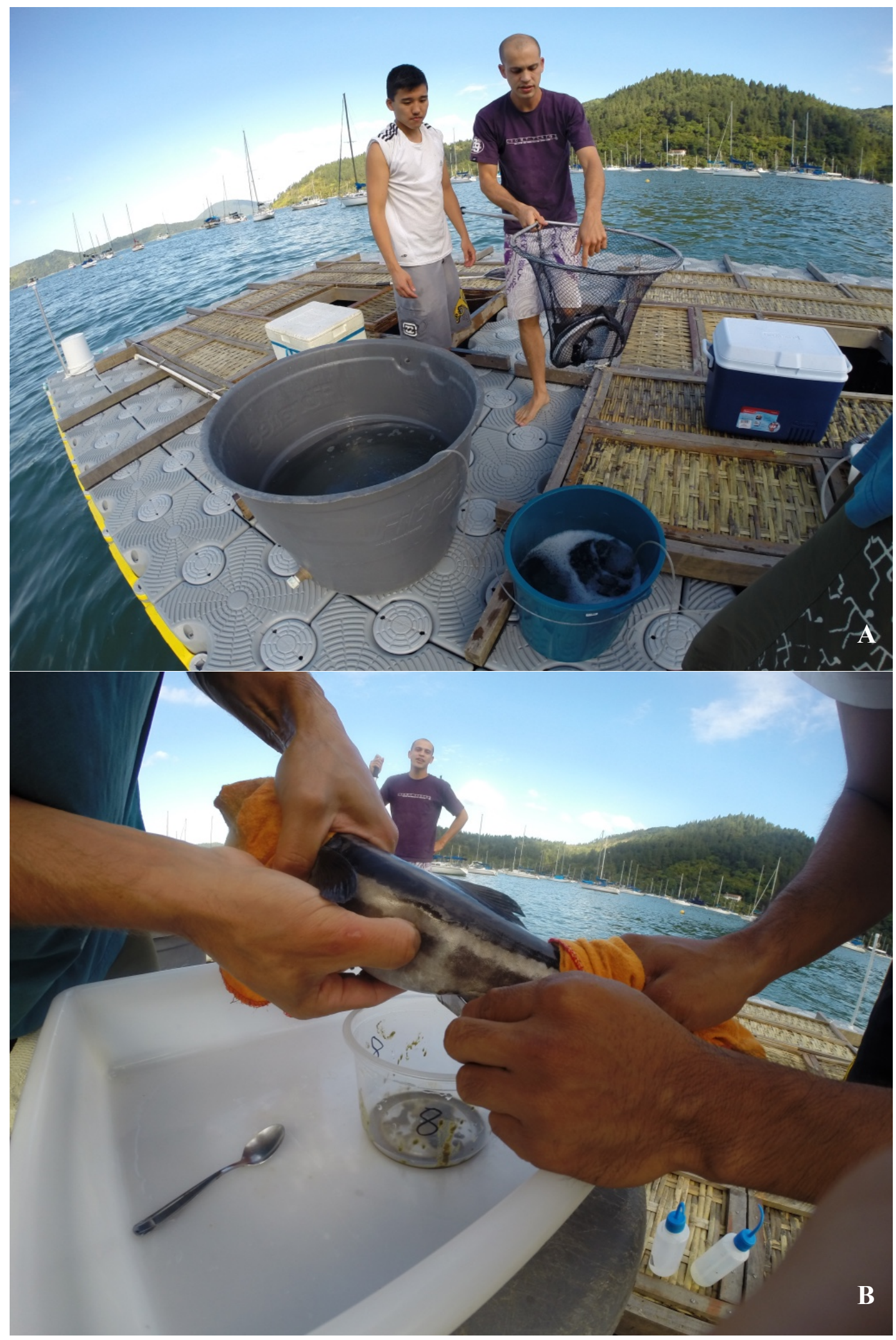

Figure 12 Feces collection: fish were anesthetized with clove oil before feces collection (A); feces were collected from each fish within each tank using stripping techniques $(\boldsymbol{B})$. 


\section{Chemical analysis}

Feed ingredients were analyzed at a commercial analytical laboratory (Labtec Laboratório de Análises Químicas Ltda, Campinas, São Paulo, Brazil), using standard AOAC (1997) methods for proximate composition. Dry matter was calculated by gravimetric analysis following oven drying at $105^{\circ} \mathrm{C}$ for $24 \mathrm{~h}$. Crude protein $(\mathrm{N} \times 6.25)$ was determined by the Dumas method (AOAC, 1997) on a Leco Truspec (Leco Corporation, St. Joseph, MI, USA). Crude fat was analyzed using hexane extraction (ANKOM XT15, ANKOM Technologic Corp, NY USA), fiber by acid and alkaline digestion (FiberCap 2021/2023, Foss Tecator, Hilleroed, DK), ash by incineration at $550^{\circ} \mathrm{C}$ in a muffle furnace, and nitrogen free extract by difference of dry matter minus the sum of protein, fat, fiber and ash. Amino acids were analyzed by HPLC (Shimadzu Prominence HPLC SPD-20A, Shimadzu Analytical, Kyoto, Japan) after acid and alkaline digestion by the ionic exchange method (KWANYUEN; BURTON, 2010). Tryptophan was analyzed after alkaline hydroxylation with lithium hydroxide.

The proximate composition of whole-body, diets and feces was determined according to standards methods (AOAC, 1997), as previously detailed describe in Chapter 2. Briefly, dry matter was calculated by gravimetric analysis following oven drying at $105^{\circ} \mathrm{C}$ for $24 \mathrm{~h}$. Ash content was determined gravimetrically by combustion in a furnace at $550^{\circ} \mathrm{C}$ for $6 \mathrm{~h}$ (Method 942.05; AOAC, 1997). Crude protein was analyzed in quadruplicate by determination of total nitrogen $(\mathrm{N} \times 6.25)$ according to the Kjeldahl method using block digestion and steam distillation (Model Kjeltec $^{\text {tm }} 8200$, Foss, DK). Crude fat was determined in triplicate by the Soxhlet extraction method using petroleum ether (Model ST255 Soxtec $^{\mathrm{tm}}$, Foss, DK). The chromic oxide contents of diets and feces was determined using a spectrophotometric by the method of 1,5-diphenylcarbazide for the determination of chromium as adjusted by BREMERNETO et al. (2005). 


\section{Whole-body amino acids}

For the trash-fish treatment, carcass amino acids and crude protein contents of cobia at the beginning and end of the cage feeding trial was determined to assess increments of body protein and amino acids during the feeding period. Ten individuals were randomly sampled at the start and five of each cage at the end of the feeding experiment, weighed, and freeze-dried for subsequent amino acid analysis.

Amino acid concentrations in carcasses was determined by high-performance liquid chromatography (HPLC) in a commercial laboratory (CBO Análises Laboratoriais, Campinas, SP, Brazil). Preparation for HPLC analysis involved hydrolysis of the samples according to the procedures described by WHITE et al. (1986). Briefly, the samples were hydrolysed with $6 \mathrm{~N}$ hydrochloric acid containing phenol $(3 \mathrm{~g} / \mathrm{L})$ for $24 \mathrm{~h}$ at $110.9^{\circ} \mathrm{C}$. 2-Aminobutyric acid was added to the hydrolysate as an internal standard. Each hydrolysate was then diluted and adjusted to $\mathrm{pH}$ 2.2 to 2.3 , the same as the amino acid standard. The hydrolysates were passed through a $0.45-\mu \mathrm{m}$ Millex-HV ${ }^{\circledR}$ membrane filter (Millipore, Bedford, MA). Amino acids in the sample were prederivatised with phenylisothiocyanate (PITC, or Edman's reagent). The derivatized sample (PTC derivative, $20 \mu \mathrm{L})$ was diluted with sample diluent $(20 \mu \mathrm{L}, 5 \mathrm{mM}$ sodium phosphate $\mathrm{NaHPO}_{4}$ buffer, $\mathrm{pH}$ 7.4: acetonitrile 95:5 v/v) before being injected into reversed-phase binary gradient HPLC, using a Shimadzu ${ }^{\circledR}$ amino acid analysis system (Shimadzu, Kyoto, Japan), fitted with a packed column (C18, 4.6 X $250 \mathrm{~mm}$; model CTO-20A, Shimadzu, Kyoto, Japan) maintained at $50 \pm 1{ }^{\circ} \mathrm{C}$ in a column oven to be detected by their UV absorbance ( $\lambda \max 254 \mathrm{~nm}$; model SPD-20A, Shimadzu, Kyoto, Japan). The mobile phase eluents used were eluents A and $\mathrm{B}$, whereas eluent A comprised sodium acetate $(940 \mathrm{ml}, \mathrm{pH}$ 6.6) mixed with acetonitrile $(60 \mathrm{ml})$, and eluent B used was acetonitrile: sodium acetate $(60: 40, \mathrm{v} / \mathrm{v})$.

For the determination of tryptophan, samples were hydrolysed enzymatically with Pronase (Pancreatin) at $45^{\circ} \mathrm{C}$ for 24 hours, followed by colorimetric reaction with 4-Dimethylamino benzaldehyde (DAB) in $21.2 \mathrm{~N}$ sulfuric acid and read on a spectrophotometer at $590 \mathrm{~nm}$. Tryptophan content was calculated from a standard curve, according to SPIES (1967). The quantification of amino acids was carried out by comparing the sample with the standard, and the results were expressed as \% dry sample basis. 


\section{Estimation of essential amino acid requirements}

Daily amino acid retention (\%) in the whole-body of cobia was calculated using the method proposed by OGINO, 1980:

Daily AA retention $(\%)=($ final $\%$ of specific AA * final body weight $)-($ initial $\%$ of specific AA * initial body weight) / number of days.

The whole-body essential amino acid (EAA) profile of cobia was used to calculate the $\mathrm{A} / \mathrm{E}$, which is defined as the content of each essential amino acid divided by the sum of all essential amino acids, including cysteine and tyrosine, multiplied by 1,000 (ARAI, 1981). Requirements in EAA, except lysine and methionine, were estimated following the formula recommended by ARAI (1981):

EAA requirement ratio $=[\mathrm{A} / \mathrm{E}$ of essential amino acid * (lysine or methionine requirement $(\%)] /(\mathrm{A} / \mathrm{E}$ ratio of lysine or methionine in the carcass), using lysine or methionine requirement values determined by ZHOU et al. (2006, 2007).

For comparison purposes, requirement on EAA of cobia was thus estimated by both carcass deposition (OGINO, 1980) and carcass composition (ARAI, 1981) methods.

\section{Apparent digestibility coefficients}

Apparent digestibility coefficients for dry matter and crude protein of the experimental diets were calculated using the following equations (CHO et al., 1985):

ADC Dry matter $(\%)=100-[100 *(\%$ marker in feed $/ \%$ marker in feces $)]$; where marker $\left(\mathrm{Cr}_{2} \mathrm{O}_{3}\right)$ were expressed as \% (dry matter basis).

ADC Crude protein $(\%)=100-[100 *(\%$ marker in feed $/ \%$ marker in feces $) *(\% \mathrm{CP}$ in feces / \% CP in feed)]; where crude protein (CP) and marker $\left(\mathrm{Cr}_{2} \mathrm{O}_{3}\right)$ were expressed as \% (dry matter basis). 


\section{Water quality parameters}

Temperature, salinity and dissolved oxygen (DO) were monitored daily using a YSI $85^{\circledR}$ Meter (YSI Inc., Yellow Springs, OH). These parameters were measured twice a day (8:00 and 16:00) from inside two randomly selected net-cages, and outside the floating platform, and in the morning (8:00) within the recirculating-water tanks.

\section{Statistical analysis}

Data were analyzed as a design using the $\mathrm{JMP}^{\circledR}$ version 12.0.1 (SAS Institute Inc., Cary, NC, USA). Significant differences in the means between dietary treatments were evaluated by one-way ANOVA and Tukey's multiple range tests, and with Student's t-test where there were only two treatments. Probabilities were considered significant at $P<0.05$. 


\subsection{Results}

\section{Sea net-cage feeding trial}

\section{Water quality}

Water quality was determined as described previously and varied as follows over the 10weeks feeding trial: water temperature $24.9 \pm 1.3^{\circ} \mathrm{C}$; salinity $33.7 \pm 0.2 \mathrm{ppt}$; dissolved oxygen $5.73 \pm 0.36 \mathrm{mg} / \mathrm{L}$ (Figure 13). These parameters were measured twice a day (8:00 and 16:00) from inside two selected cages and outside the floating platform, and there was no significant difference between the results. Some pollutants were observed during the trial, mainly from the recreational boats anchored around the experimental floating platform, however this pollution did not appear to negatively influence fish behavior and performance. However, during the very low tides, the net cages touched the bottom sediment which stressed the animals, causing reduced feed intake at these times. A similar decrease in feed intake was also observed during rainstorms due to increase water turbidity.

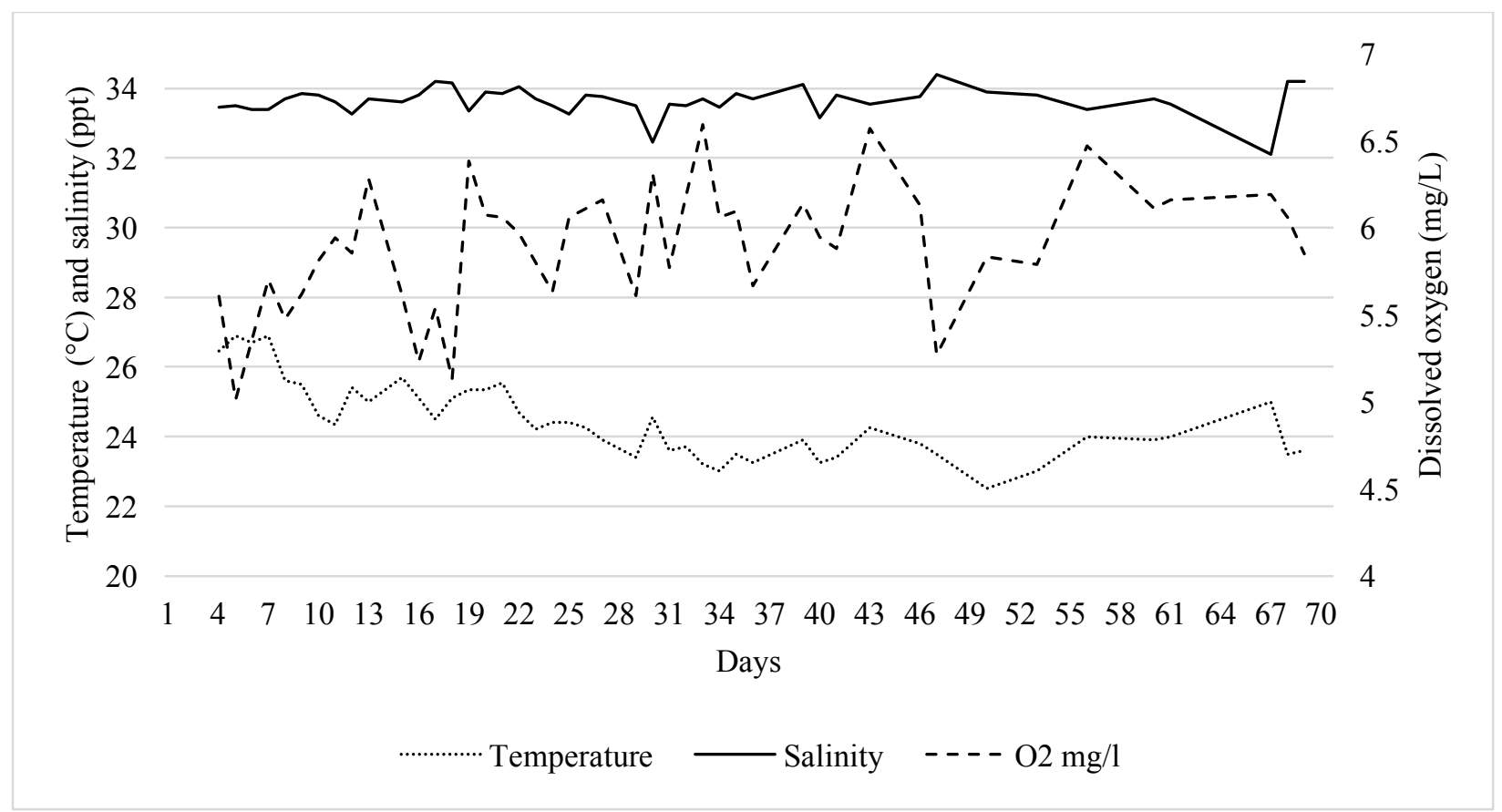

Figure 13 Temperature $\left({ }^{\circ} \mathrm{C}\right)$, salinity (ppt), and dissolved oxygen $(\mathrm{mg} / \mathrm{L})$ variations during the 70-day experimental period in the sea net-cage feeding trial with cobia Rachycentron canadum. 


\section{Animal performance}

Fish performance (initial and final weight, net production, weight gain, SGR, PER, FCR and survival) results for the 10-week outdoor net-cage feeding trial are presented in Table 5. As expected, fish fed with Trash-fish diet showed the highest final weight $(630.6 \pm 27.1 \mathrm{~g})$, whilst for the dry pellets diets, the Aquamar diet showed the best performance (final weight $526.4 \pm$ 46.3g; FCR $1.6 \pm 0.1$ ) compared with the Commercial diet (final weight 413.2 \pm 51.3 , FCR $1.9 \pm$ 0.2). The protein PER was significant higher for the trash-fish $(1.6 \pm 0.0)$ diet, compared with all other treatments. There are some considerations regarding the high FCR values observed fish fed the Trash-fish and Semi-moist diets (3.80 \pm 0.1 and $2.3 \pm 0.1$, respectively), and this was related to their higher moisture content $(69.0 \pm 0.2$, and $32.8 \pm 0.1 \%$, respectively). All treatments displayed good survival over the 10-week feeding period, ranging from 98.0 to $100.0 \%$ (Table 5). 
Table 5 - Juvenile cobia Rachycentron canadum growth and feed performance in the outdoor cage net system over the 10-week experimental period.

\begin{tabular}{|c|c|c|c|c|c|c|c|c|}
\hline Diet & $\begin{array}{l}\text { Initial body } \\
\text { weight }(\mathrm{g})\end{array}$ & $\begin{array}{l}\text { Final body } \\
\text { weight }(\mathrm{g})\end{array}$ & $\begin{array}{l}\text { Net production } \\
\text { per tank }(\mathrm{g})\end{array}$ & $\begin{array}{l}\text { Weight gain } \\
(\%)\end{array}$ & SGR & FCR & PER & $\begin{array}{l}\text { Survival } \\
(\%)\end{array}$ \\
\hline Aquamar & 127.1 & $526.4^{\mathrm{a}}$ & $5989.3^{\mathrm{a}}$ & $314.5^{\mathrm{ab}}$ & $2.0^{\mathrm{ab}}$ & $1.6^{\mathrm{c}}$ & $1.2^{\mathrm{b}}$ & 100.0 \\
\hline Semi-moist & 131.8 & $557.8^{\mathrm{a}}$ & $6389.7^{\mathrm{a}}$ & $323.8^{\mathrm{ab}}$ & $2.0^{\mathrm{ab}}$ & $2.3^{\mathrm{b}}$ & $1.1^{\mathrm{b}}$ & 100.0 \\
\hline Trash-fish & 122.7 & $630.6^{\mathrm{a}}$ & $7618.3^{\mathrm{a}}$ & $413.9^{\mathrm{a}}$ & $2.3^{\mathrm{a}}$ & $3.8^{\mathrm{a}}$ & $1.6^{\mathrm{a}}$ & 100.0 \\
\hline Commercial & 128.2 & $413.2^{\mathrm{b}}$ & $4044.0^{\mathrm{b}}$ & $226.3^{\mathrm{b}}$ & $1.7^{\mathrm{b}}$ & $1.9^{\mathrm{c}}$ & $1.3^{\mathrm{b}}$ & 97.8 \\
\hline
\end{tabular}

Values (mean for 3 replicates per diet).

Different superscript letters within the same column indicate significant difference $(P<0.05)$.

Weight gain $(\%)=($ final weight - initial weight $) /$ initial weight $* 100$.

$\mathrm{SGR}-$ specific growth rate $=(\ln$ final weight - initial weight $) /$ days $* 100)$.

FCR - feed conversion ratio $=$ total feed offered $(\mathrm{g}) /($ final fish biomass $(\mathrm{g})-$ initial fish biomass $(\mathrm{g}))$.

PER - protein efficiency ratio $=$ grams weight gained $/$ grams protein fed. 


\section{Apparent digestibility coefficient}

The estimation of ADC of dry matter (DM) and crude protein (CP) was only possible for the diets containing the external marker $\mathrm{Cr}_{2} \mathrm{O}_{3}$, namely the Aquamar and Semi-moist diets. Significant differences were observed in ADC of DM between the diets Aquamar (69.4\%) and Semi-moist (82.6\%). Similarly, the ADC of CP for the Semi-moist diet was significant higher (89.6\%), comparing with the Aquamar diet (78.7\%) (Table 6).

Table 6 - Apparent digestibility coefficients (ADC) for dry matter (DM) and crude protein (CP) by juvenile cobia fed the six experimental diets*.

\begin{tabular}{lll}
\hline Diet & DM & CP \\
\hline Aquamar & $69.4^{\mathrm{a}}$ & $78.7^{\mathrm{a}}$ \\
Semi-moist & $82.6^{\mathrm{b}}$ & $89.6^{\mathrm{b}}$ \\
\hline
\end{tabular}

*Values are means for 4 replicates per diet. Different superscript letters within the same column indicate significant difference $(P<0.05)$ for ADC values.

\section{Feed intake}

The sum of morning (9:00) and afternoon (16:00) feed intake ( $\mathrm{kg}$, as fed basis) is presented in Figure 14. A trend for higher feed consumption was observed during the morning (9:00) for fish fed the Aquamar, trashfish and Semi-moist diets, whilst the reverse was true for fish fed the Commercial diet.

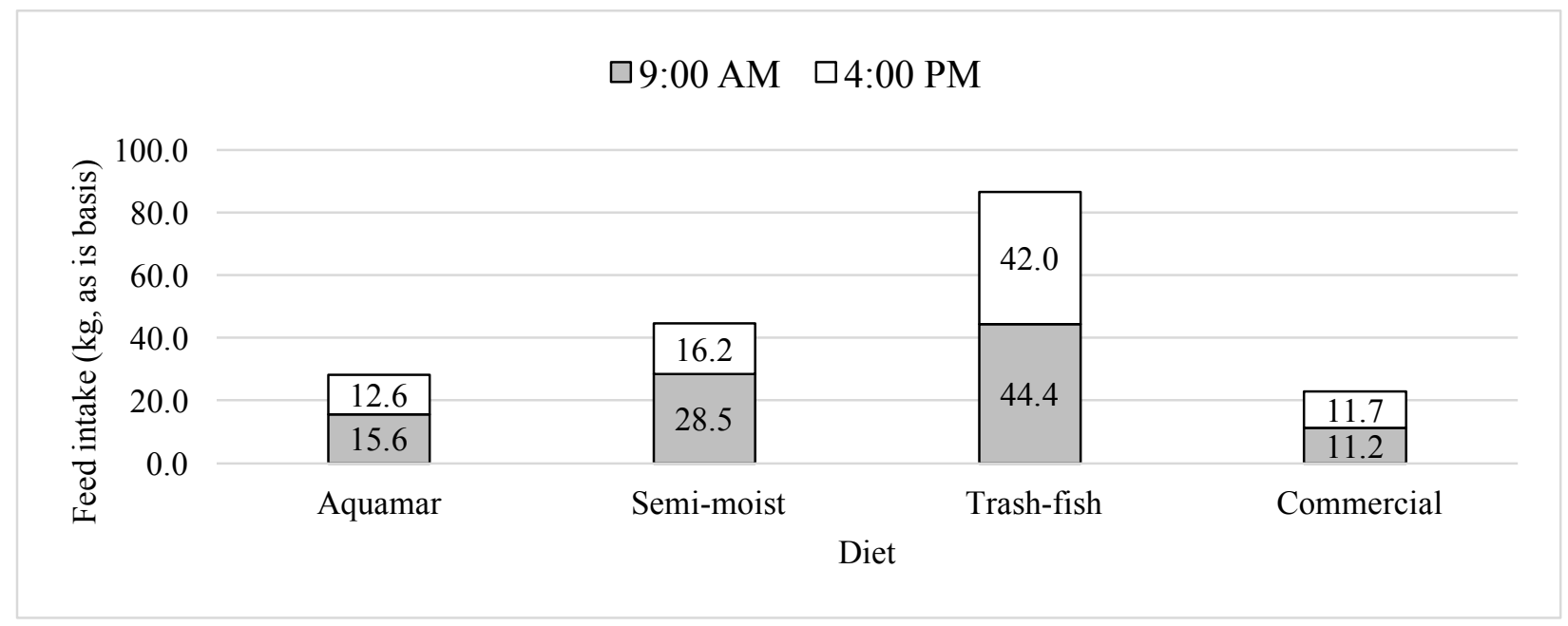

Figure 14 Total feed intake (kg, as is basis) of juvenile cobia Rachycentron canadum fed the three experimental diets and one commercial feed for 10 weeks (sum weight; $n=3$ ). 
Hepatosomatic index

The hepatosomatic index (HIS) is presented in Figure 15. No significant differences $(P<$ 0.05) were observed between the Aquamar, Trash-fish, and Semi-moist diet. However, a higher HSI was observed in fish fed the Commercial diet $(3.9 \pm 0.4)$.

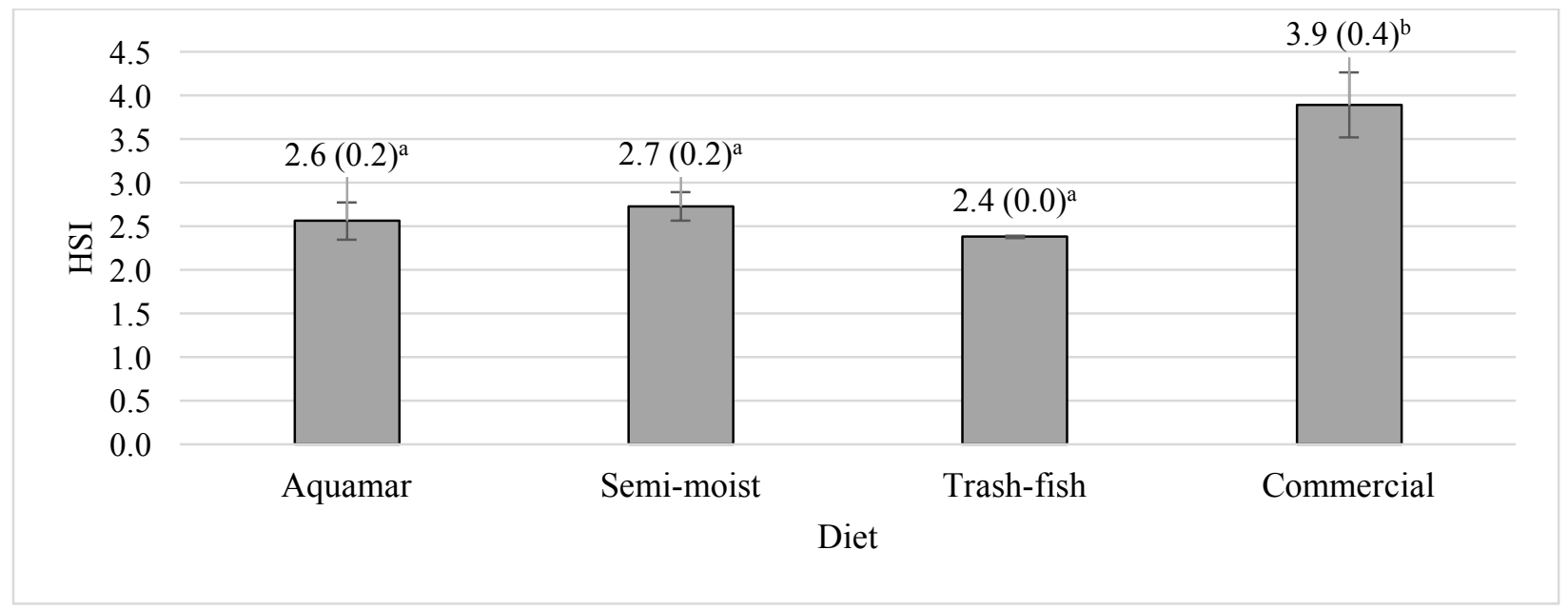

Figure 15 Hepatosomatic index (HIS) of juvenile cobia Rachycentron canadum fed three experimental diet and one commercial feed for 10 weeks (mean $\pm s d ; n=3)$. Different superscript letters indicate significant difference (P < $0.05)$.

\section{Histological examinations}

All the sampled fish presented round hepatocytes with an increased volume and presence of cytoplasmatic macrovacuoles with well-defined limits and some peripheral nuclei, distributed in a diffuse manner. These findings suggested a lesion with steatosis or fatty metamorphosis. This morphology was more evident for those cobia fed the Commercial feed (Figure 16). No apparent differences were found in livers from fish fed the Semi-moist and Trash-fish. Smaller and regular hepatocytes were found in those cobia fed the Aquamar diet (Figure 16). 


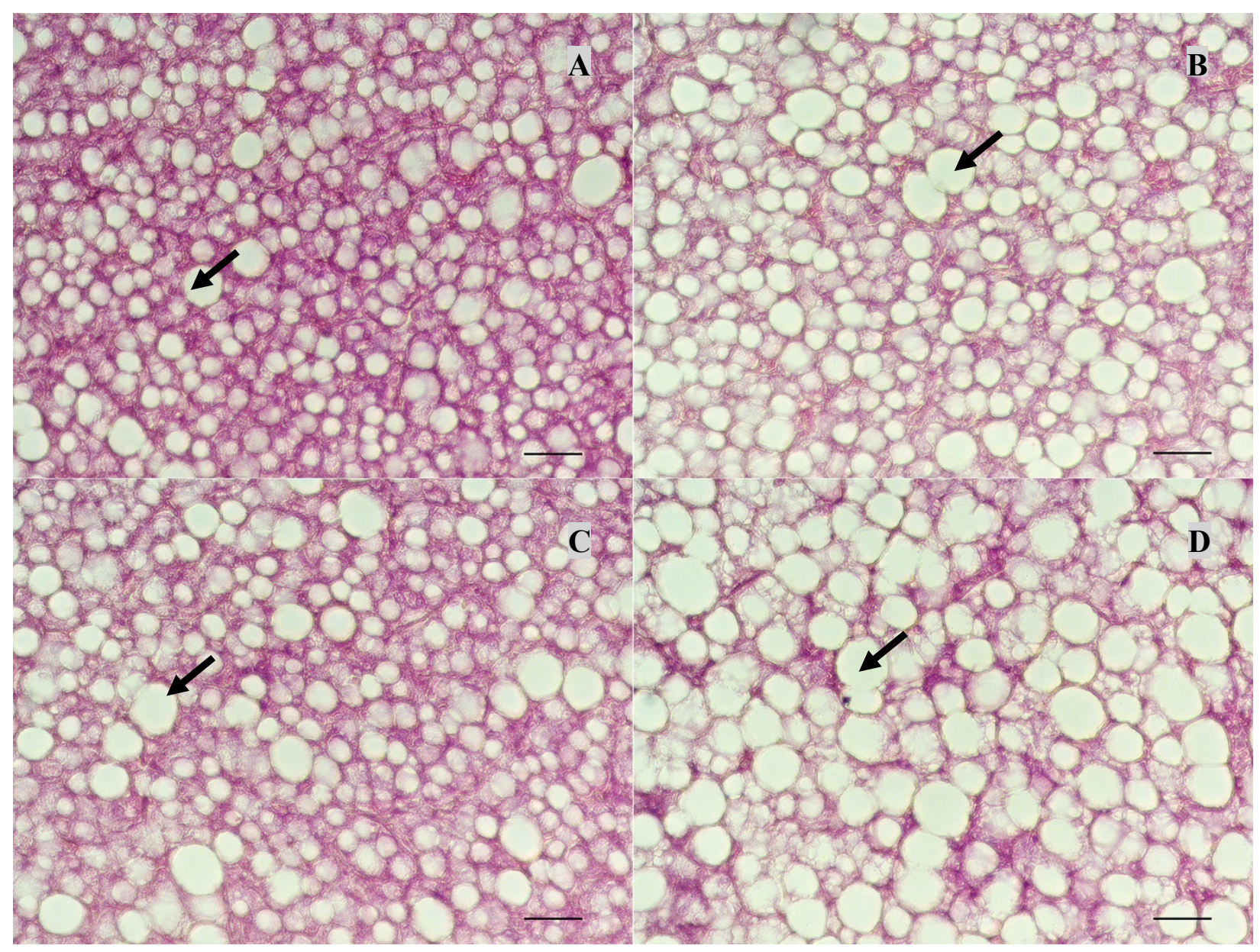

Figure 16 Hepatocytes from juvenile cobia Rachycentron canadum fed the four diets Aquamar (A), Semi-moist (B), Trash-fish (C), and Commercial (D), showing large lipid vacuoles (black arrows) occupying the whole cytoplasm and displacing cell nuclei to peripheral cell margins (hematoxylin-eosin, 40x). Bar $=20 \mu \mathrm{m}$.

Visual body cavity analysis

Overall the visual aspect of the body cavities of the three experimental diets (Aquamar, Trash-fish, and Semi-moist) were very similar, with no drastic differences noticed in the size and coloration of the internal organs. However, a substantial amount of fat deposition attached to the intestine was observed in the body cavity within all treatments. The most noticeable difference was observed in fish fed the Commercial diet, where a significant increase of visceral fat content, pale liver coloration and swollen liver were observed in all of the four fish sampled from each cage (Figure 17). 


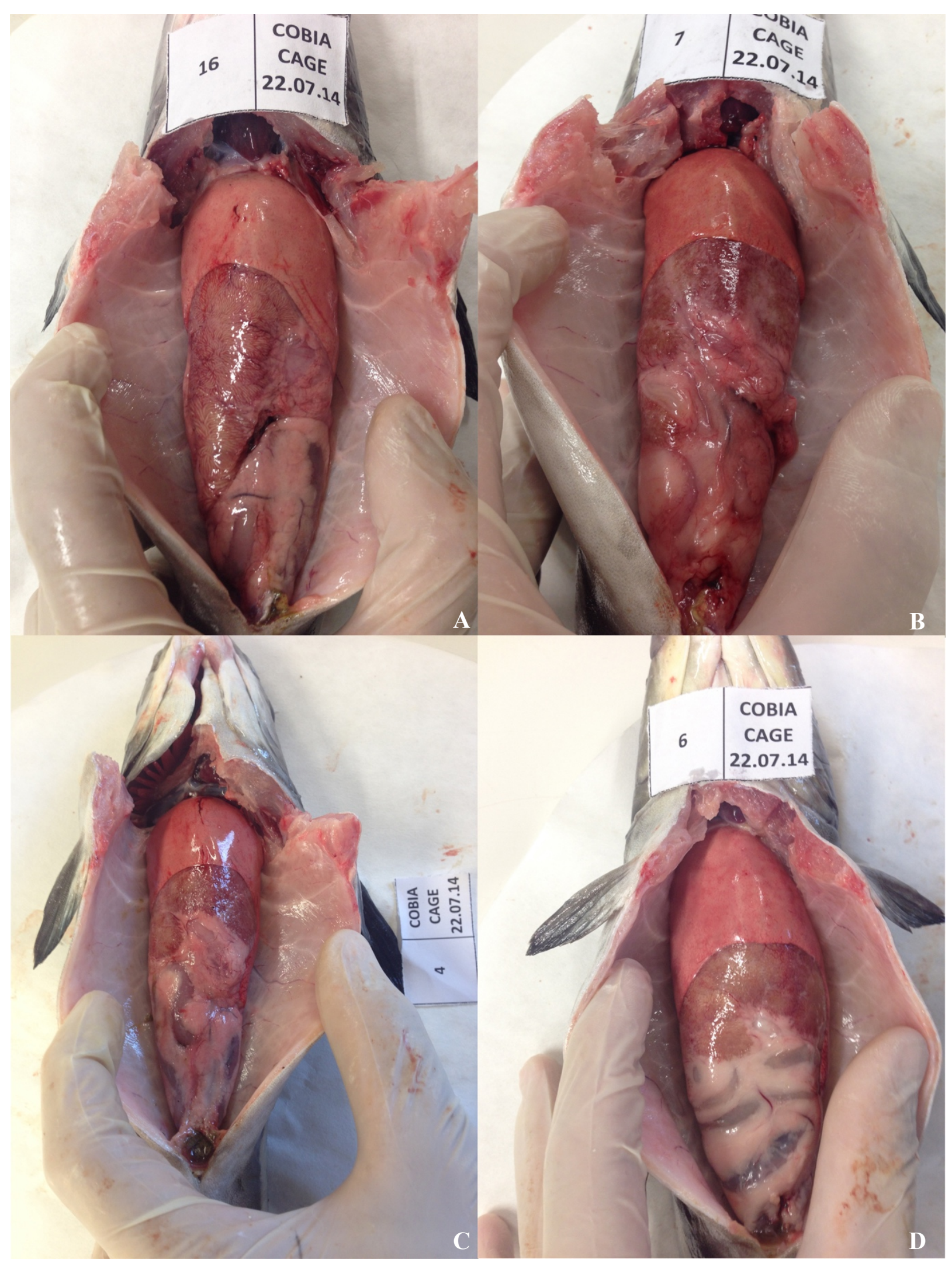

Figure 17 Visual body cavity: pictures of juvenile cobia Rachycentron canadum fed experimental diets Aquamar (A), Trash-fish (B), Semi-moist (C) and Commercial feed (D) for 10 weeks. 
Diets, whole-body and trash-fish amino acid composition

The dietary (trash-fish) and whole-body (initial and final WB) amino acid profiles (\%, as is basis) are given in Table 7. As expected, lysine was the most abundant essential amino acid, while tryptophan and taurine were the lowest of these found in both initial and final WB samples and trash-fish. The dietary (Aquamar and Commercial) amino acid profiles (\%, as is basis) are shown in Table 8. Different composition was observed between these two diets. A lack of taurine was observed in the Commercial feed. In addition, tryptophan was not analyzed for both diets.

Good correlation $\left(R^{2}=0.98\right)$ of the amino acid profiles were obtained between both initial and final WB carcass samples. Overall, these values did not show a great variation when compared with the Trash-fish amino acid profile. The A/E ratios of the essential amino acid compositions of whole-body (initial and final) revealed a similar trend (Table 9).

\section{Estimation of essential amino acid requirements}

The final whole-body amino acid profile and estimate of dietary amino acid requirement (\% dry matter basis) of cobia, based on carcass daily deposition (OGINO, 1980) and amino acid profile ratio (ARAI, 1981) methods is presented in Table 10. The values are expressed as percent total dry matter, in order to be compared with published values. Since lysine is normally the first limiting amino acid in most feedstuffs, the requirements for the other indispensable amino acids are usually expressed in relation to the lysine requirement based on the amino acid profile method (ARAI, 1981). Also, for comparison reason, methionine was used as the reference amino acid. A significant correlation $\left(\mathrm{R}^{2}=0.99\right)$ was obtained comparing the final whole-body EAA profile with the estimated EAA requirements by the OGINO method (Figure 18). When it was compared with the estimated EAA by the ARAI method, also a high correlation $\left(\mathrm{R}^{2}=0.99\right)$ was obtained when lysine was used as the reference amino acid. The same occurred when methionine was used as reference (Figure 18). Overall, the estimated values of EAA obtained by the ARAI method (A/E ratio) using the requirement of lysine $(2.33 \%)$ as the reference amino acid, where below the values acquired by the OGINO method. Furthermore, when the requirement of methionine (1.69\%) was used as the reference amino acid, the results were highly correlated with 
the OGINO method results (Table 10). Graphical comparison of methods for estimating essential amino acid requirements from whole-body amino acid profile is presented in Figure 18.

Table 7 - Dietary (trash-fish, Sardinella brasiliensis) and whole-body (initial and final) amino acid profiles of juvenile cobia Rachycentron canadum.

\begin{tabular}{|c|c|c|c|}
\hline$E A A^{a}(\%$, "as-is" basis) & Trash-fish & Initial whole-body & Final whole-body \\
\hline Arginine & 1.02 & 1.04 & 1.04 \\
\hline Histidine & 0.63 & 0.35 & 0.32 \\
\hline Isoleucine & 0.80 & 0.71 & 0.71 \\
\hline Leucine & 1.18 & 1.09 & 1.03 \\
\hline Lysine & 1.52 & 1.40 & 1.38 \\
\hline Methionine & 0.46 & 0.41 & 0.40 \\
\hline Phenylalanine & 0.68 & 0.61 & 0.58 \\
\hline Threonine & 0.74 & 0.70 & 0.68 \\
\hline Tryptophan & 0.23 & 0.22 & 0.27 \\
\hline Valine & 1.00 & 0.87 & 0.85 \\
\hline Taurine & 0.20 & 0.18 & 0.13 \\
\hline \multicolumn{4}{|l|}{$N E A A^{b}(\%$, "as-is" basis) } \\
\hline Cystine & 0.48 & 0.45 & 0.40 \\
\hline Tyrosine & 0.55 & 0.51 & 0.47 \\
\hline Serine & 0.66 & 0.64 & 0.60 \\
\hline Glycine & 1.18 & 1.23 & 1.37 \\
\hline Aspartic Acid & 1.37 & 1.23 & 1.32 \\
\hline Glutamic Acid & 2.23 & 2.15 & 2.20 \\
\hline Proline & 0.72 & 0.74 & 0.82 \\
\hline Alanine & 1.10 & 1.04 & 1.08 \\
\hline Total amino acids ( $\mathrm{AAA})$ & 16.73 & 15.57 & 15.66 \\
\hline Crude protein (\%, "as is" basis) & 18.93 & 16.71 & 16.36 \\
\hline Mean fish weight (g) & - & 127.8 & 630.6 \\
\hline
\end{tabular}

${ }^{\mathrm{a}}$ Essential amino acids.

${ }^{\mathrm{b}}$ Nonessential amino acids.

Values are mean $(n=2)$. 
Table 8 - Amino acid composition (\%, "as is" basis) of diet Aquamar and Commercial feed.

\begin{tabular}{lll}
\hline$E A A^{a}$ & Aquamar $^{1}$ & Commercial $^{2}$ \\
\hline Arginine & 2.60 & 2.29 \\
Histidine & 0.97 & 1.23 \\
Isoleucine & 1.37 & 1.31 \\
Leucine & 2.89 & 3.91 \\
Lysine & 2.65 & 2.65 \\
Methionine & 0.91 & 1.07 \\
Phenylalanine & 1.56 & 1.98 \\
Threonine & 1.50 & 1.66 \\
Tryptophan & - & - \\
Valine & 1.59 & 2.34 \\
Taurine & 0.27 & 0.00 \\
NEAA & & \\
Cystine & 0.37 & 0.40 \\
Tyrosine & 0.87 & 1.19 \\
Serine & 1.79 & 1.82 \\
Aspartic Acid & 2.69 & 3.08 \\
Glutamic Acid & 7.20 & 6.49 \\
Proline & 3.16 & 2.64 \\
Alanine & 2.80 & 3.09 \\
\hline Experimenta & &
\end{tabular}

${ }^{1}$ Experimental dry cold-pelleted diet.

${ }^{2}$ Cobia extruded commercial diet (Matsuda Nutrição Animal, São Sebastião do Paraíso, MG, Brazil).

${ }^{a}$ Essential amino acids.

${ }^{\mathrm{b}}$ Nonessential amino acids.

Dash indicates not determined. 
Table 9 - $\mathrm{A} / \mathrm{E}^{\mathrm{a}}$ ratios of the amino acid composition of whole-body (initial and final) of juvenile cobia Rachycentron canadum, and trash-fish (mainly Sardinella brasiliensis).

\begin{tabular}{llll}
\hline$E A A^{b}$ & Initial body-weight & Final body-weight & Trash-fish \\
\hline Arginine & 121.9 & 125.9 & 107.6 \\
Histidine & 41.1 & 38.2 & 66.0 \\
Isoleucine & 83.5 & 85.6 & 84.5 \\
Leucine & 127.7 & 125.1 & 124.7 \\
Lysine & 163.8 & 166.7 & 159.8 \\
Methionine & 48.1 & 48.6 & 48.1 \\
Phenylalanine & 71.4 & 69.8 & 71.8 \\
Threonine & 81.9 & 81.9 & 78.3 \\
Tryptophan & 25.6 & 32.8 & 24.1 \\
Valine & 101.3 & 103.5 & 105.5 \\
Taurine & 21.0 & 16.2 & 20.6 \\
$N E A A^{c}$ & & & \\
Cystine & 52.4 & 48.6 & 50.9 \\
Tyrosine & 60.2 & 56.9 & 58.1 \\
Serine & 75.3 & 73.2 & 69.1 \\
Glycine & 144.0 & 165.4 & 124.0 \\
Aspartic Acid & 143.6 & 160.4 & 144.3 \\
Glutamic Acid & 251.6 & 266.4 & 235.4 \\
Proline & 86.6 & 99.8 & 75.6 \\
Alanine & 122.3 & 130.9 & 115.8 \\
\hline
\end{tabular}

${ }^{\mathrm{a}} \mathrm{A} / \mathrm{E}$ (amino acid essential rate $)=($ amount of each amino acid in whole-body / total essential amino acids, including cystine and tyrosine) $* 1,000$.

${ }^{\mathrm{b}}$ Essential amino acids.

${ }^{\mathrm{c}}$ Nonessential amino acids. 
Table 10 - Final whole-body amino acid profile and estimative of dietary amino acid requirement of cobia Rachycentron canadum, as based on carcass daily deposition ${ }^{1}$ and wholebody amino acid profile methods ${ }^{2,3}$.

\begin{tabular}{|c|c|c|c|c|}
\hline & \multirow{2}{*}{ Final whole-body } & \multicolumn{3}{|c|}{ Estimation method } \\
\hline & & Ogino $(1980)^{1}$ & Arai $(1981)^{2}$ & Arai $(1981)^{3}$ \\
\hline \multicolumn{5}{|l|}{$E A A^{a}(\%$, dry matter $)$} \\
\hline Arginine & 3.03 & 3.00 & 1.76 & 3.08 \\
\hline Histidine & 0.92 & 0.89 & 0.53 & 0.94 \\
\hline Isoleucine & 2.06 & 2.04 & 1.20 & 2.10 \\
\hline Leucine & 3.01 & 2.94 & 1.75 & 3.06 \\
\hline Lysine & 4.01 & 3.96 & 2.33 & 4.08 \\
\hline Methionine & 1.17 & 1.15 & 0.68 & 1.19 \\
\hline Phenylalanine & 1.68 & 1.64 & 0.98 & 1.71 \\
\hline Threonine & 1.97 & 1.94 & 1.14 & 2.00 \\
\hline Tryptophan & 0.79 & 0.82 & 0.46 & 0.80 \\
\hline Valine & 2.49 & 2.46 & 1.45 & 2.53 \\
\hline Taurine & 0.39 & 0.35 & 0.23 & 0.40 \\
\hline \multicolumn{5}{|l|}{$N E A A^{b}(\%$, dry matter $)$} \\
\hline Cystine & 1.17 & 1.13 & - & - \\
\hline Tyrosine & 1.37 & 1.33 & - & - \\
\hline Serine & 1.76 & 1.72 & - & - \\
\hline Glycine & 3.98 & 4.04 & - & - \\
\hline Aspartic Acid & 3.86 & 3.90 & - & - \\
\hline Glutamic Acid & 6.41 & 6.39 & - & - \\
\hline Proline & 2.40 & 2.44 & - & - \\
\hline Alanine & 3.15 & 3.15 & - & - \\
\hline Total amino acids ( $\left.\sum \mathrm{AA}\right)$ & 45.62 & 45.62 & - & - \\
\hline
\end{tabular}

${ }^{\mathrm{a}}$ Essential amino acids.

${ }^{b}$ Nonessential amino acids.

${ }^{1}$ Ogino (1980) Daily AA retention $(\%)=($ final \% of specific AA * final body weight) - (initial $\%$ of specific AA * initial body weight) / number of days.

${ }^{2}$ Arai $(1981)$ EAA requirement $=[\mathrm{A} / \mathrm{E}$ of essential amino acid $*($ lysine requirement $(\%)] /$ $(\mathrm{A} / \mathrm{E}$ ratio of lysine in the final $\mathrm{WB})$. Lysine requirement of 2.33 (\% dry $\mathrm{CP}$ ) estimated by broken-line (Zhou et al., 2007).

${ }^{3}$ Arai $(1981)$ EAA requirement $=[\mathrm{A} / \mathrm{E}$ of essential amino acid $*$ (methionine requirement $(\%)]$ / $(\mathrm{A} / \mathrm{E}$ ratio of methionine in the final WB). Methionine requirement of $1.19(\%$ dry $\mathrm{CP})$ estimated by broken-line (Zhou et al., 2006).

Dash indicates not determined or zero if not present. 


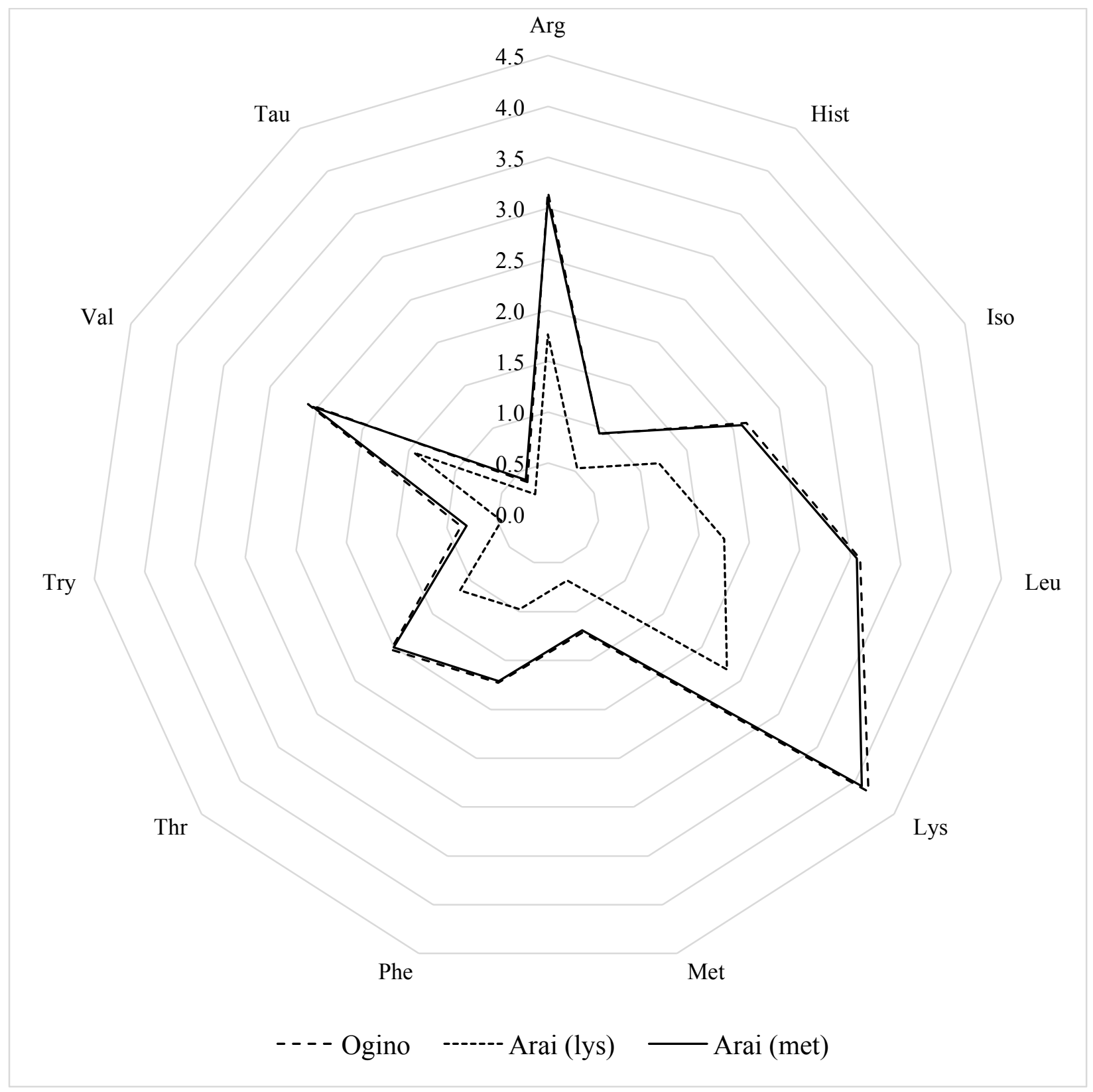

Figure 18 Graphical comparison of methods for estimating essential amino acids (EAA) requirements from wholebody amino acid profile of cobia Rachycentron canadum. Arg: arginine, His: histidine, Iso: isoleucine, Leu: leucine, Lys: lysine, Met: methionine, Phe: phenylalanine, Thr: threonine, Try: tryptophan, Val: valine, and Tau: taurine. Ogino: Daily AA retention (\%) = (final \% of specific AA * final body weight) - (initial \% of specific AA * initial body weight) / number of days; Arai (lys): EAA requirement $=(A / E$ of essential amino acid * (lysine requirement $(\%)) /(A / E$ ratio of lysine in the final WB). Lysine requirement of $2.33(\%$ dry CP) estimated by broken-line (Zhou et al., 2007); Arai (met): EAA requirement $=($ A/E of essential amino acid $*$ (methionine requirement $(\%)) /(A / E$ ratio of methionine in the final WB). Methionine requirement of 1.19 (\% dry CP) estimated by broken-line (Zhou et al., 2006). 
The estimated contents of EEA to meet the minimum requirements of EEA under different conditions (digestibility coefficients and dietary crude protein contents) at 3\% of feeding rate are shown in Table 11. The values are expressed in $\mathrm{g} / 100 \mathrm{~g}$ (dry matter basis), and the content to meet the daily EAA requirements is variable with feeding level and level in diet and digestibility of protein sources.

Table 11 - The content of EAA $(\mathrm{g} / 100 \mathrm{~g})$ in dry matter basis to meet the requirements of EAA of cobia when fed under the conditions of $45 \%$ and $50 \%$ CP in diet, $80 \%$ and $90 \%$ of apparent digestibility coefficient of crude protein, feeding rate $3 \%$ of body weight*.

\begin{tabular}{lllll}
\hline Crude protein & \multicolumn{2}{c}{$50 \%$} \\
\hline Digestibility (\%) & 80.0 & 90.0 & 80.0 & 90.0 \\
\hline Arginine & 1.98 & 1.76 & 1.78 & 1.58 \\
Histidine & 0.58 & 0.52 & 0.52 & 0.47 \\
Isoleucine & 1.34 & 1.19 & 1.21 & 1.07 \\
Leucine & 1.93 & 1.72 & 1.74 & 1.55 \\
Lysine & 2.60 & 2.32 & 2.34 & 2.08 \\
Methionine & 0.76 & 0.67 & 0.68 & 0.61 \\
Phenylalanine & 1.08 & 0.96 & 0.97 & 0.86 \\
Threonine & 1.27 & 1.13 & 1.15 & 1.02 \\
Tryptophan & 0.54 & 0.48 & 0.49 & 0.43 \\
Valine & 1.62 & 1.44 & 1.46 & 1.30 \\
Taurine & 0.23 & 0.21 & 0.21 & 0.18 \\
\hline
\end{tabular}

*The estimation was based on the amino acid profiles of whole-body (Ogino, 1980). 


\section{Recirculating-water tank feeding trial}

\section{Water quality}

Water quality parameters over the course of the recirculating-water tank feeding trial are presented in Table 12 and Figure 19. The average water temperature $\left(24.7 \pm 1.0^{\circ} \mathrm{C}\right)$ was below the expected level set by the heater $\left(28^{\circ} \mathrm{C}\right)$. Moreover, the trial was conducted in the beginning of autumn, when the temperature usually starts to decline. Salinity was constant $(34.4 \pm 2.0 \mathrm{ppt})$ and dissolved oxygen were kept in average of $5.77 \pm 1.49 \mathrm{mg} / \mathrm{L}$.

Table 12 - Water quality parameters over the 10-weeks indoor tank feeding trial.

\begin{tabular}{llll}
\hline Temperature $\left({ }^{\circ} \mathrm{C}\right)$ & Salinity $(\mathrm{ppt})$ & Dissolved oxygen $(\%)$ & Dissolved oxygen $(\mathrm{mg} / \mathrm{L})$ \\
\hline $24.7(1.0)$ & $34.4(2.0)$ & $80.7(11.3)$ & $5.77(1.49)$ \\
\hline
\end{tabular}

Values (mean \pm s.d. for 3 replicates).

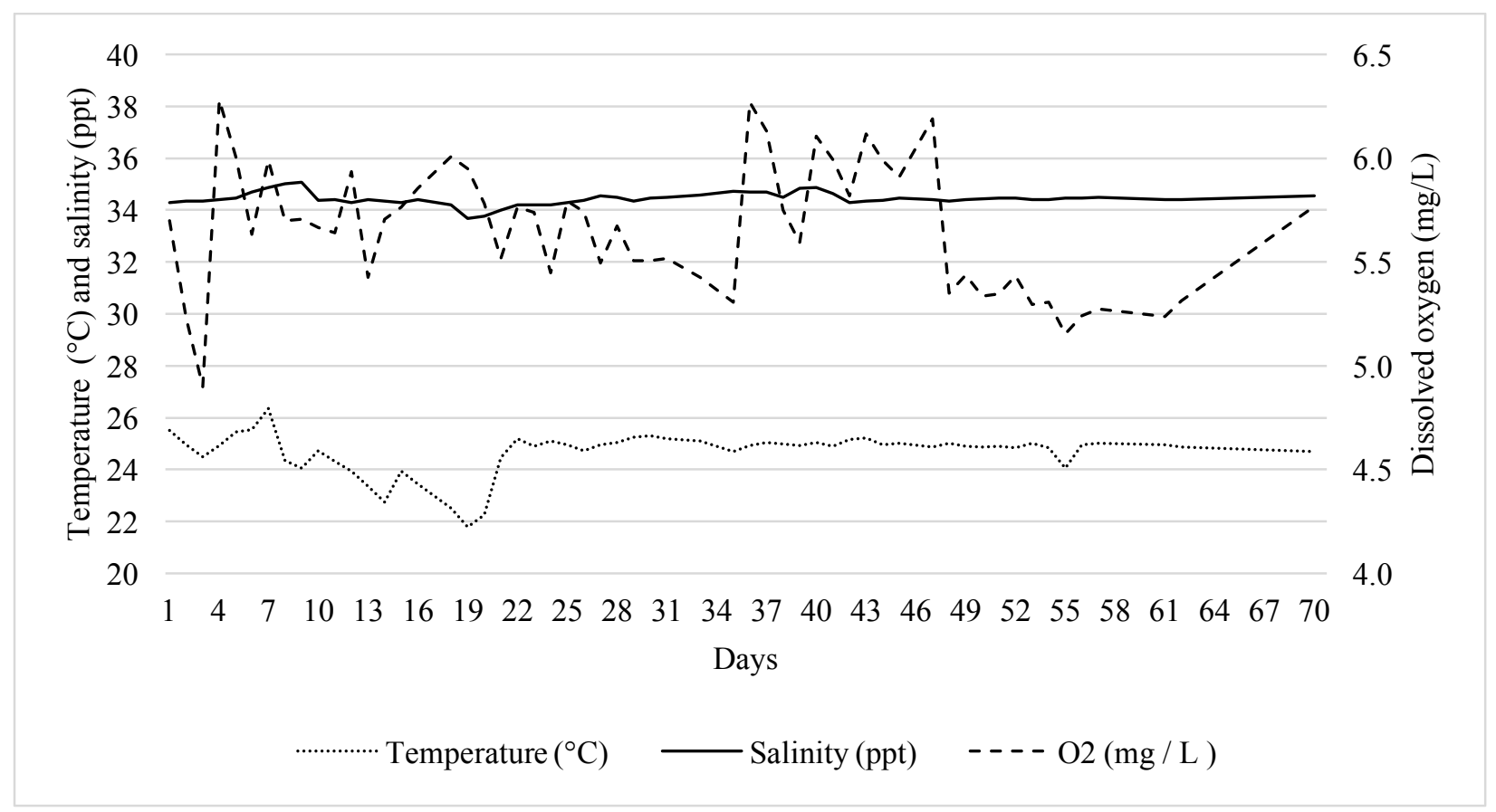

Figure 19 Temperature $\left({ }^{\circ} \mathrm{C}\right)$, salinity (ppt), and dissolved oxygen (mg/L) variations during the 70-day experimental period in the recirculating-water tank feeding trial with cobia Rachycentron canadum. 


\section{Growth and feed performance}

The growth and feed performance data are presented in Table 13. No significant difference was observed in mean final body weight between fish fed the six experimental diets, with fish fed the commercial control diet displaying significantly lower final body weight and growth response. The poorest feed conversion rates (FCR) were observed for fish fed AM3-PBM $(1.4 \pm 0.1)$, AM5-PBF $(1.4 \pm 0.1)$ and the Commercial diet $(1.6 \pm 0.1)$. Similar FCRs were recorded for diets AM1-NFM (1.2 \pm 0.0$)$, AM2-CFM (1.2 \pm 0.1$)$, AM4-SPC (1.3 \pm 0.0$)$, and AM6-TAU $(1.3 \pm 0.1)$. No mortality was recorded over the 10 -week trial period. 
Table 13 - Juvenile cobia Rachycentron canadum growth and feed performance in the indoor tank system over the 10-week experimental period.

\begin{tabular}{|c|c|c|c|c|c|c|c|c|}
\hline Diet & $\begin{array}{l}\text { Initial body } \\
\text { weight }(\mathrm{g})\end{array}$ & $\begin{array}{l}\text { Final body } \\
\text { weight }(\mathrm{g})\end{array}$ & $\begin{array}{l}\text { Net production } \\
\text { per tank }(\mathrm{g})\end{array}$ & $\begin{array}{l}\text { Weight gain } \\
(\%)\end{array}$ & SGR & FCR & PER & $\begin{array}{l}\text { Survival } \\
(\%)\end{array}$ \\
\hline AM1-NFM & 87.6 & $301.7^{\mathrm{a}}$ & 1712.5 & $244.2^{\mathrm{a}}$ & $1.8^{\mathrm{a}}$ & $1.2^{\mathrm{c}}$ & 1.8 & 100.0 \\
\hline AM2-CFM & 87.7 & $295.6^{\mathrm{a}}$ & 1662.7 & $237.0^{\mathrm{a}}$ & $1.7^{\mathrm{a}}$ & $1.2^{\mathrm{c}}$ & 1.5 & 100.0 \\
\hline AM3-PBM & 87.3 & $278.6^{\mathrm{ab}}$ & 1530.3 & $219.0^{\mathrm{a}}$ & $1.7^{\mathrm{a}}$ & $1.4^{\mathrm{ab}}$ & 1.6 & 100.0 \\
\hline AM4-SPC & 91.2 & $300.8^{\mathrm{a}}$ & 1676.6 & $229.7^{\mathrm{a}}$ & $1.7^{\mathrm{a}}$ & $1.3^{\mathrm{c}}$ & 1.8 & 100.0 \\
\hline AM5-PBF & 89.8 & $310.0^{\mathrm{a}}$ & 1762.1 & $245.6^{\mathrm{a}}$ & $1.8^{\mathrm{a}}$ & $1.4^{\mathrm{bc}}$ & 1.8 & 100.0 \\
\hline AM6-TAU & 88.6 & $276.7^{\mathrm{ab}}$ & 1505.1 & $212.5^{\mathrm{ab}}$ & $1.6^{\mathrm{a}}$ & $1.3^{\mathrm{c}}$ & 1.4 & 100.0 \\
\hline Commercial & 89.1 & $242.9^{\mathrm{b}}$ & 1230.4 & $172.9^{\mathrm{b}}$ & $1.4^{\mathrm{b}}$ & $1.6^{\mathrm{a}}$ & 1.5 & 100.0 \\
\hline
\end{tabular}

Values (mean for 3 replicates per treatment).

Different superscript letters within the same column indicate significant difference $(P<0.05)$.

Weight gain $=($ final weight - initial weight $) /$ initial weight $* 100$.

SGR - specific growth rate $=($ ln final weight - initial weight $) /$ days $* 100)$.

FCR - feed conversion ratio $=$ total feed offered $(\mathrm{g}) /($ final fish biomass $(\mathrm{g})$ - initial fish biomass $(\mathrm{g}))$.

PER — protein efficiency ratio $=$ grams weight gained $/$ grams protein fed. 


\section{Apparent digestibility coefficient}

No significant difference was obtained for apparent digestibility coefficient (ADC) of dry matter (DM), the results ranging from $65.4 \%$ to $72.1 \%$. For the ADC of crude protein (CP), diets AM1-NFM $(84.1 \pm 4.8 \%)$ and AM4-SPC $(90.5 \pm 0.9 \%)$ had the best results, and significant different compared with the other diets. No ADC was estimated for the Commercial feed, since it contained no internal reference marker.

Table 14 - Apparent digestibility coefficients (ADC) for dry matter (DM) and crude protein (CP) by juvenile cobia fed the six experimental diets*

\begin{tabular}{lll}
\hline Diet & DM & CP \\
\hline AM1-NFM & $68.9(4.6)$ & $84.1(4.8)^{\mathrm{ab}}$ \\
AM2-CFM & $67.6(1.3)$ & $81.0(1.9)^{\mathrm{b}}$ \\
AM3-PBM & $67.1(1.6)$ & $83.7(2.2)^{\mathrm{b}}$ \\
AM4-SPC & $72.1(2.3)$ & $90.5(0.9)^{\mathrm{a}}$ \\
AM5-PBF & $67.8(3.8)$ & $82.2(3.3)^{\mathrm{b}}$ \\
AM6-TAU & $65.4(3.2)$ & $82.4(2.5)^{\mathrm{b}}$ \\
\hline
\end{tabular}

*Values (mean (s.d.) for 4 replicates per diet; different superscript letters within the same column indicate significant difference $(P<0.05)$ for ADC values.

\section{Feed intake}

The sum of morning (9:00) and afternoon (16:00) feed intake ( $\mathrm{kg}$, as is basis) is shown in Figure 20. No significant difference was observed between the treatments, and a trend of higher consumption in the morning (9:00) was recorded. Since the experimental diets were sinking pelleted, the duration of the feeding routine was around 1:30 to 2:00 hours, in order for one person to feed all the 28 tanks. 


\section{$\square 9: 00$ AM $\quad \square 4: 00$ PM}

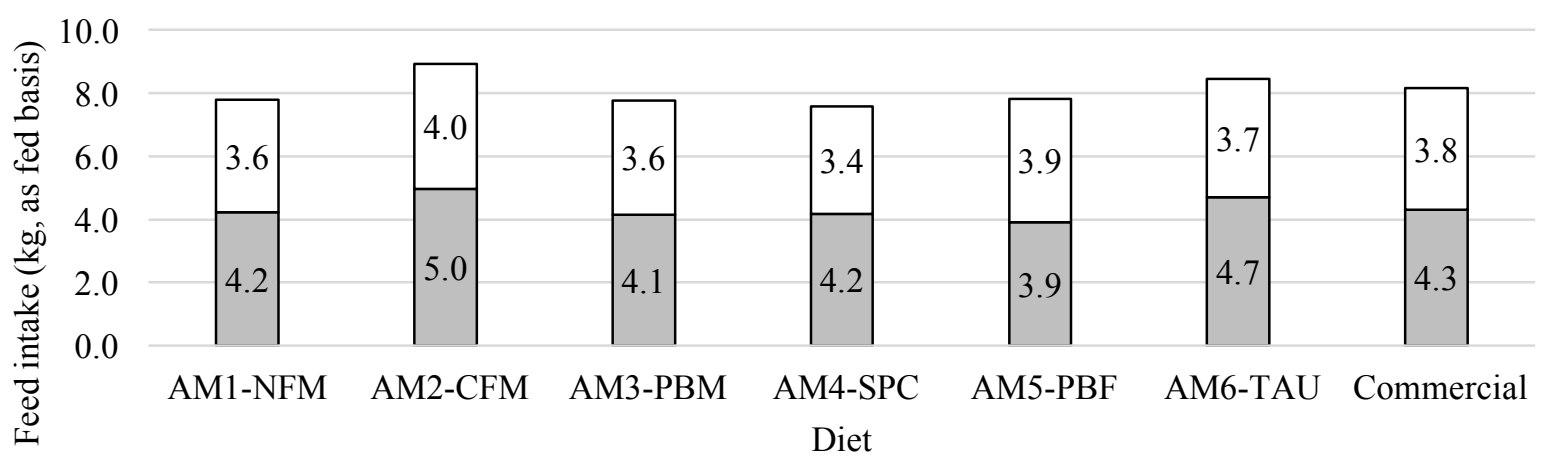

Figure 20 Total feed intake ( $\mathrm{kg}$, as fed basis) of juvenile cobia Rachycentron canadum fed the six experimental diets and one commercial feed for 10 weeks (sum weight; $n=4$ ).

\section{Hepatosomatic index}

The hepatosomatic index (HIS) is presented in Figure 21. No significant differences $(P<$ 0.05) were observed between the six experimental diets. Although, diet AM4-SPC which had the lowest fat content $(11.0 \pm 1.3 \%)$ displayed the lowest HIS $(2.2 \pm 0.1)$. However, a significant higher HSI was recorded in fish fed the Commercial diet (4.6 \pm 0.3$)$.

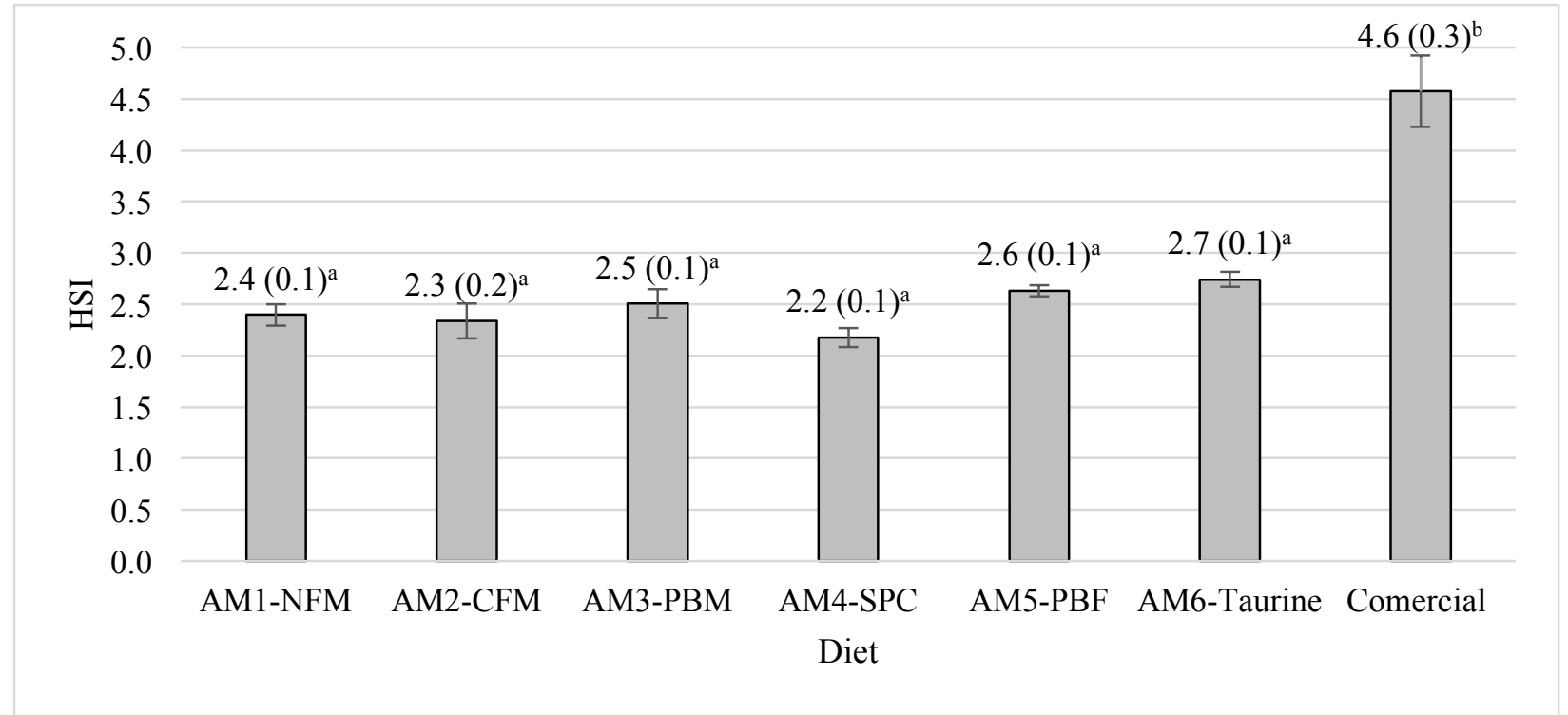

Figure 21 Hepatosomatic index (HIS) of juvenile cobia Rachycentron canadum fed six experimental diet and one commercial feed for 10 weeks (mean $\pm s d ; n=4$ ). 


\section{Histological examinations}

All the sampled fish presented round hepatocytes with an increased volume and presence of cytoplasmatic macrovacuoles with well-defined limits and some peripheral nuclei, distributed in a diffuse manner. These findings suggested a lesion with steatosis or fatty metamorphosis. This morphology was more evident for those individual fed the Commercial feed (Figure 22). No apparent differences were found in livers from fish fed the experimental diets (Figure 23).

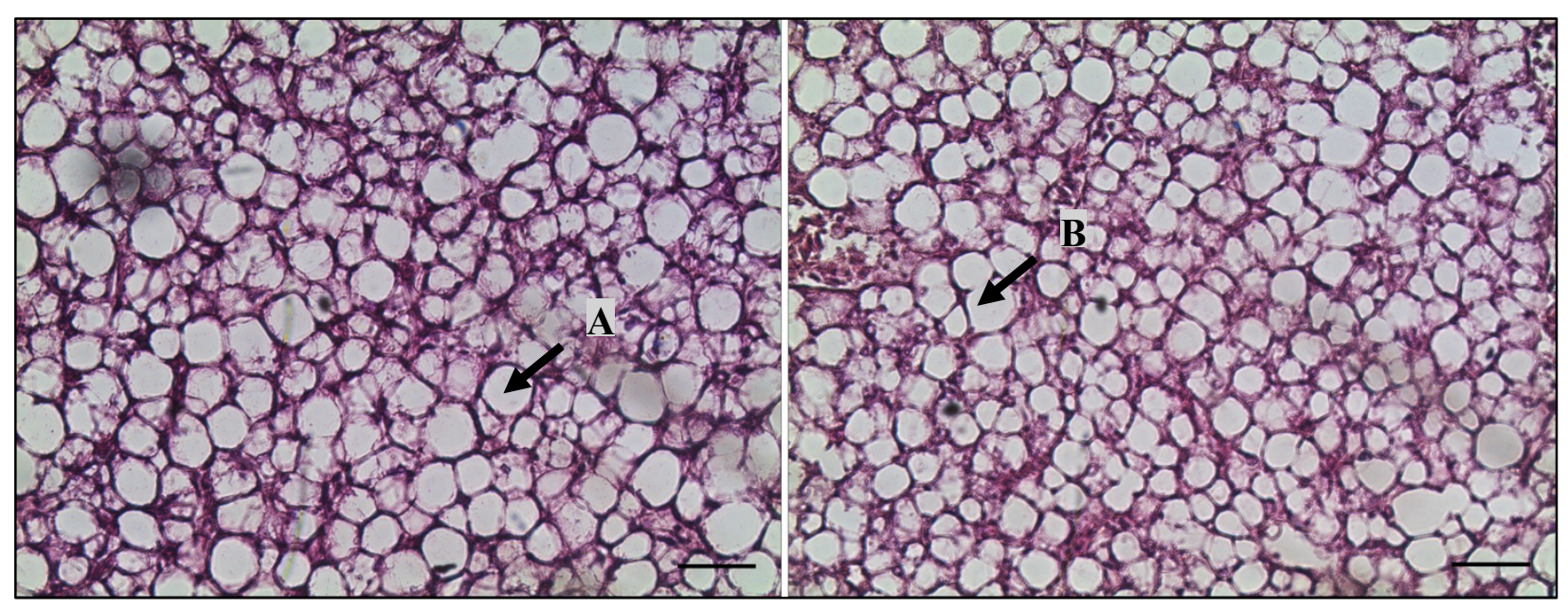

Figure 22 Hepatocytes from juvenile cobia Rachycentron canadum fed the Commercial feed, showing large lipid vacuoles $(\boldsymbol{A})$ occupying the whole cytoplasm and displacing cell nuclei $(\boldsymbol{B})$ to peripheral cell margins (hematoxylineosin, 40x). Bar $=20 \mu \mathrm{m}$. 


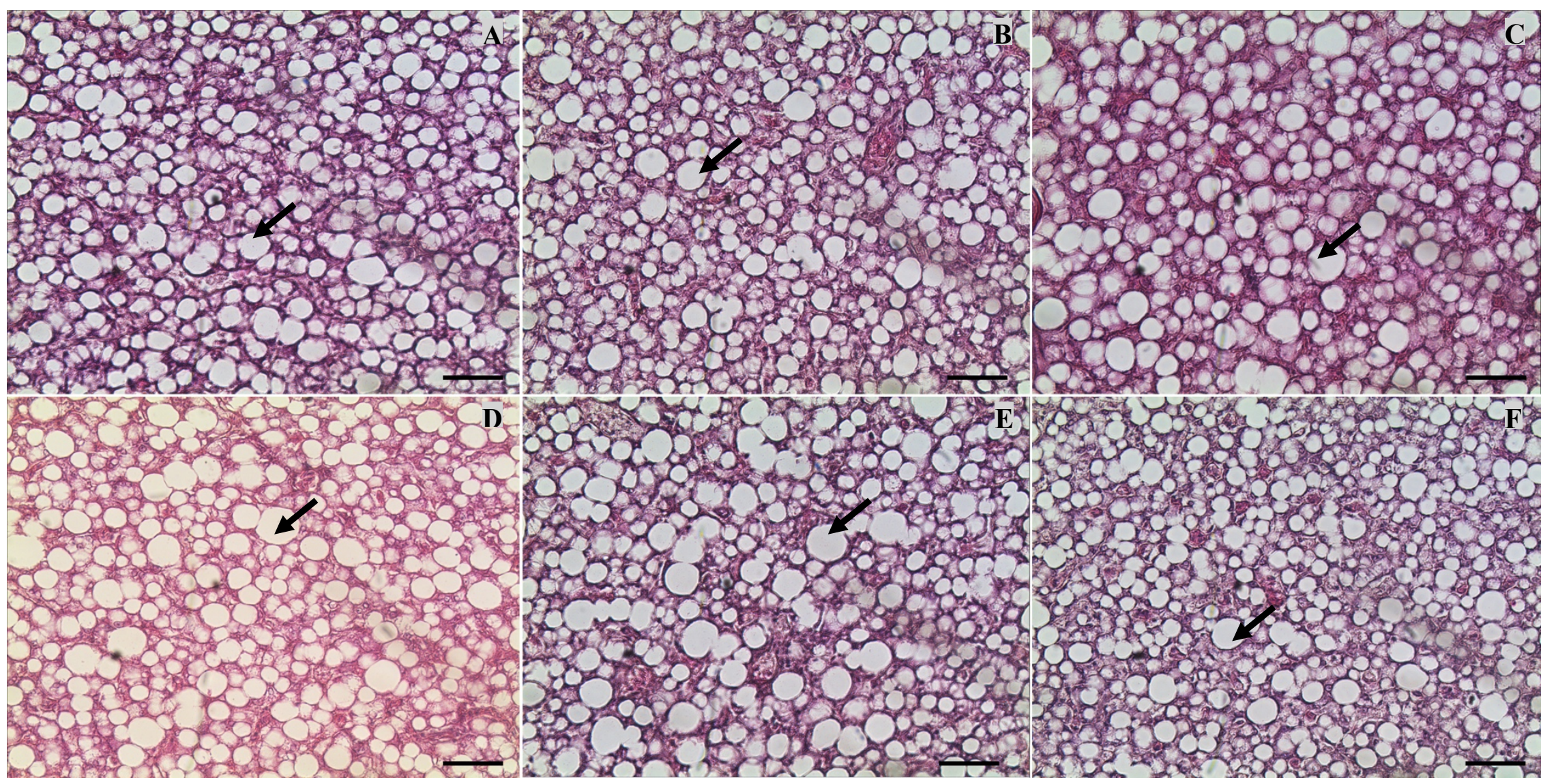

Figure 23 Hepatocytes from juvenile cobia Rachycentron canadum fed the six experimental diets AM1-NFM (A), AM2-CFM (B), AM3-PBM (C), AM4-SPC (D), $A M 5-P B F(\boldsymbol{E})$, and AM6-TAU (F), showing large lipid vacuoles (black arrows) occupying the whole cytoplasm and displacing cell nuclei to peripheral cell margins (hematoxylin-eosin, 40x). Bar $=20 \mu \mathrm{m}$. 
Visual body cavity examination

Overall the visual aspect of the body cavities of the six experimental diets were very similar, with no drastic differences noticed in the internal organ coloration and size. A substantial fat deposition in the body cavity, more evident attached to the intestine, was observed in several fishes. Nodules in the liver was found in one fish fed the Commercial diet (Figure 24). The most obvious difference was noticed for fish fed the Commercial diet, where the increase in visceral fat content, pale liver coloration and swollen liver was observed in all the four fish of each tank (Figure 25).

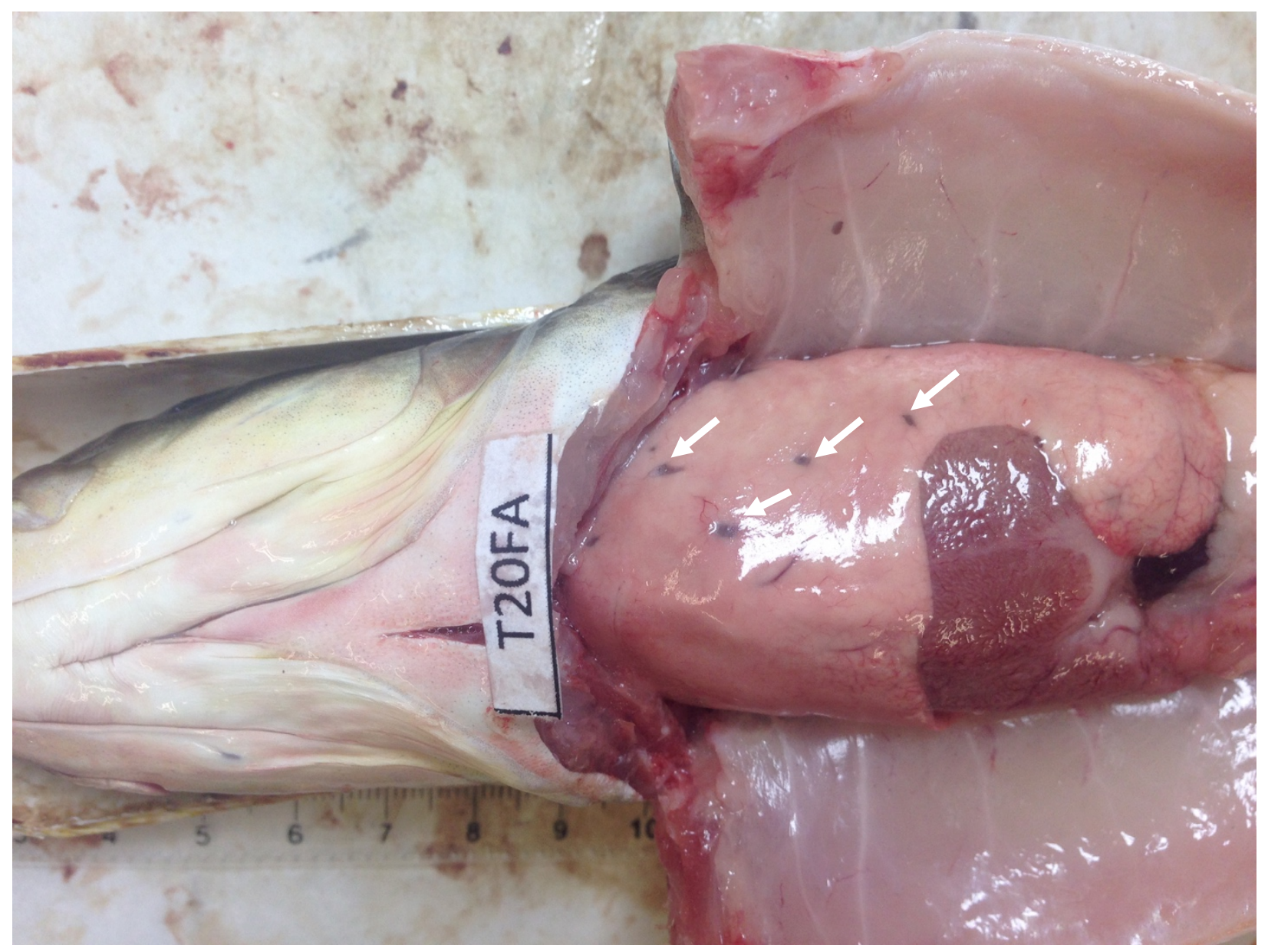

Figure 24 Dark nodules in the liver (arrows) was found in juvenile cobia fed the Commercial feed. Also, the increase of fat content, pale coloration and swollen liver was observed. 


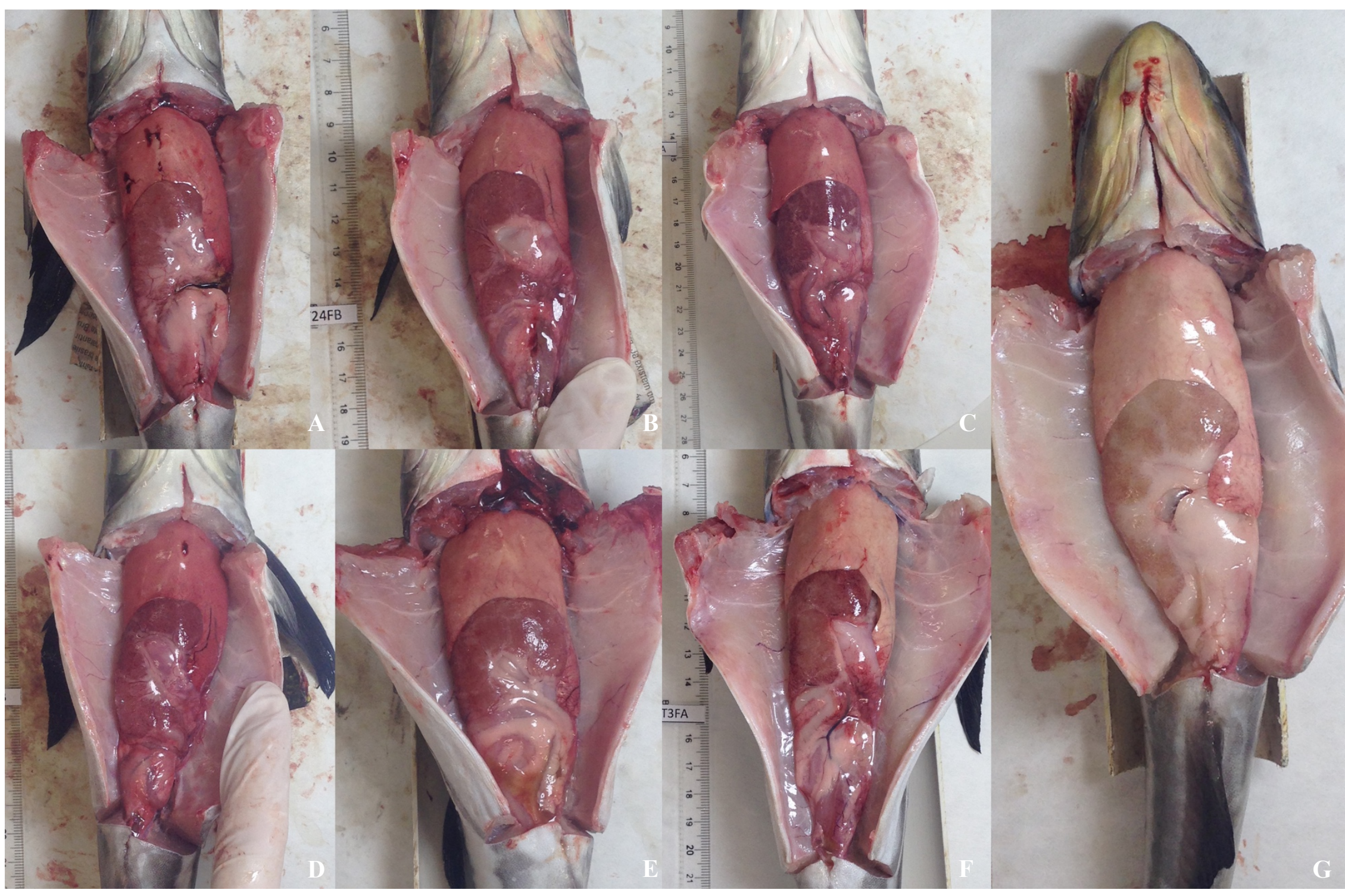

Figure 25 Visual body cavity: pictures of juvenile cobia Rachycentron canadum fed the six experimental (AM1-NFM (A), AM2-CFM (B), AM3-PBM (C) , AM4$S P C(\boldsymbol{D}), A M 5-P B F(\boldsymbol{E}), A M 6-T A U(\boldsymbol{F})$ diets, and one commercial feed Commercial (G) for 10 week. 


\subsection{Discussion}

Water quality parameters for both systems during each trial were within ideal ranges for cobia, with the exception of the water temperature (sea net-cage trial: $24.5 \pm 1.1^{\circ} \mathrm{C}$; recirculatedwater tank trial: $24.8 \pm 2.1^{\circ} \mathrm{C}$ ). CHEN; SUN (2014) showed that juvenile cobia grew fastest at $33^{\circ} \mathrm{C}$ when fed at satiation but with growth rate equal or better at $27^{\circ} \mathrm{C}$ when food was restricted, whereas the fish showed overall significant lower growth rates at $21^{\circ} \mathrm{C}$ except for the starved treatment. In another study (CHEN; SUN, 2009), it was showed an improved energy utilization with increased fish size at temperature range of $27-33^{\circ} \mathrm{C}$. In the present study, the average temperatures for both trials were below this range, and might have negatively affected fish performance. Despite this, the fish were still very active during this study. DENSON et al. (2003) suggested that juvenile cobia require moderate to high salinity (20-35 ppt) for sustained growth and health, which is in accordance with the results recorded in both trial (34 ppt). Unfortunately, total ammonia nitrogen, nitrite and $\mathrm{pH}$ was not measured during both trials. In order to maintain high water quality parameter in the recirculated-water tanks system, fresh filtered seawater was added to account for the daily loss of about $10 \%$ of total water volume per day.

With the exception of fish fed the trash-fish control diet, which displayed the best growth response and feed performance, fish weight gain (WG) in both feeding trials were not significantly different between the experimental diets, and it is in accordance with results reported in other studies with cobia with similar body weight and experiment period (ESTRADA et al., 2015). However, in both trials fish fed the Commercial diet presented the poorest growth and feed response. This poor performance may have to do with the lack of taurine, and also other factors. LUNGER et al. (2007), working with juvenile cobia initially weighing 28g, recommended taurine supplementation at $0.5 \%$ (diet). Amino acid analysis of the Commercial diet showed acceptable content of methionine and lysine (1.07 and 2.65\%, respectively), but did not were detected taurine in its composition (Table 8).

Regarding the protein efficiency ratio (PER), the treatment trash-fish diet had the best result (1.6) compared with individuals fed the Aquamar and Semi-moist diets (1.2 and 1.1, respectively). This result was probably due to the higher $\mathrm{CP}$ digestibility of the trash-fish 
treatment. In the recirculating-water tanks trial, cobia fed the various diets with different protein sources exhibited equal PER, which indicated no detrimental impact of plant based and animal by-products protein incorporation. Compared to other published studies with cobia (CHOU et al., 2004; ZHOU et al., 2005), the values obtained in the present study were very similar. ZHOU et al. (2005) observed PERs ranging from 1.3 to 1.8 , very alike of those observed in the present study, which ranged from 1.6 to 1.8 in the recirculated tanks trial and 1.1 to 1.6 in the cage net trial. The average feed conversion ratios (FCR) obtained in this study are in accordance with results obtained in experimental trials conducted with small animals and not reaching market size (2-5kg). LIAO et al. (2004) recorded FCR value of 1.5 for cobia reared in grow-out cages. BENETTI et al. (2010) observed a variation in FCR values between 1.3 and 2.2 and the overall estimated FCR of cobia was 1.8 during 10 months culture period. A similar trend was observed in the present study. In commercial farms, as a consequence of disease outbreaks, escapes and highly variable survival rates, FCR fluctuate broadly between the juvenile stages and the later stages.

Some studies have shown that it is possible to use diets for cobia juveniles with low inclusion levels of fishmeal. CHOU et al. (2004), working with $32.0 \mathrm{~g}$ cobia juveniles have obtained good growth with feeds containing $26.9 \%$ fishmeal and $28.6 \%$ soybean meal. These authors suggested that the methionine level of diets with increased substitution of fishmeal was the probably limiting factor of growth. In this work, the diet with maximum replacement of fishmeal that caused no significant interruption in growth, contained $2.65 \mathrm{~g}$ of sulfur amino acids (methionine and cystine) / $100 \mathrm{~g}$ of $\mathrm{CP}$ or $1.28 \%$ of the diet $(0.85 \%$ methionine on a dry matter basis). With a similar objective but working with smaller fish, ZHOU et al. (2005) carried out an experiment with cobia ( $8.3 \mathrm{~g}$ body weight) in floating cages for eight weeks. The animals were fed iso-proteic and iso-lipidic diets (45\% CP and 15\% fat) with increasing levels of soybean meal to replace fishmeal. The authors observed that the performance of cobia was not affected when it was replaced up to $20 \%$ of fishmeal in the diet with soybean meal, concluding that the optimal inclusion of fishmeal and soybean meal was $40.5 \%$ and $13.5 \%$, respectively.

The differences between both studies (CHOU et al., 2004; ZHOU et al., 2005) and the present study are related with the source and quality of fishmeals and the use of purified proteins and additives in the diet. Both studies used casein, choline chloride and anchovy flour, 
commonly produced from whole fish, with a crude protein content of between 67.8 and $70.7 \%$. In the present study the fishmeal used was derived from the residue of sardine and farmed salmon processing wastes respectively, with a CP content of 59.2 and $65.8 \%$, respectively. Therefore, the differences in inclusions of fishmeal and methionine in the studies were probably due to differences in the protein digestibility of the ingredients used. On the other hand, ZHOU et al. (2004) evaluated the digestibility of protein, lipids and EAA for cobia juveniles. The authors concluded that the fishmeal (Peruvian), soybean meal, poultry meal, meat and bone meal, peanut meal and canola meal had a protein and lipid digestibility higher than $87 \%$ and methionine digestibility of $90 \%$. Although it was not possible to compare diets based only on their ingredients content, the differences show that cobia was able to efficiently use a variety of different feed ingredient sources. However, the present study showed that the cobia fed the Commercial feed displayed suboptimal growth and performance compared with all experimental diets in both net-cages and recirculating-water tanks, despite the diet having a $\mathrm{CP}$ and lipid content of $41.5 \%$ and $18.5 \%$, respectively. This poor performance might also be due to the low digestibility of the diet compared with the other diets used in the study.

There is a possibility that a significant portion of the gross energy content of the Commercial feed was derived from carbohydrates of low nutrient digestibility, such as those present within conventional soybean meal. Unlike the Commercial feed, a significant portion of the gross energy of the experimental diets was present in the form of fish oil of high nutrient digestibility for marine fish (NRC, 2011). However, there are some inconsistencies regarding the lipid requirements of cobia in the literature. One of the first studies conducted on this topic (CHOU et al., 2001) suggested that cobia had a lipid requirement of about 5.76\%. The authors reported that diets containing $31.0 \%$ of fishmeal and $11.5 \%$ of soybean meal, and up to $18.9 \%$ lipid (dry basis) resulted in low growth. CRAIG et al. (2006), working with cobia juveniles (body weight of $7.4 \mathrm{~g}$ and $185.9 \mathrm{~g}$ ) obtained the best results in weight gain with diets containing $12.0 \%$ total lipids. These results contradict what has been observed in a commercial level in Asia. Feeds for marine fish typically contain lipid levels up to 18\% (NUNES; MADRID, 2013). According to CRAIG et al. (2006), in Taiwan and other Asian countries, cobia are raised with diets containing $48 \%$ crude protein (CP) and 18\% lipids (dry basis), whereas in the United States, commercial feeds are made with excessive levels of CP, around 58\% and 15\% lipid (dry 
basis). The high lipid content of Asian diets, according to the authors, was attributed to the fact that cobia in these countries was being produced and sold for the sashimi market, which requires a greater deposition of fat in the meat.

The fishmeal replacement studies on cobia using other protein sources have shown positive results as reported by some researchers. ZHOU et al. (2004) evaluated the ability of cobia to digest fish meal, soybean mean (roasted and defatted), poultry meal, meat and bone meal, peanut meal, rapeseed meal, and corn gluten meal. The digestibility of dry matter for all ingredients was generally poor, especially for plant-based ingredients, but cobia was capable of effectively digesting protein and lipid in almost all ingredients. Protein digestibility was worst for rapeseed meal and meat and bone meal. Energy digestibility for fishmeal and poultry meal was significantly higher than for peanut meal, rapeseed meal, and solvent-extracted soybean meal, while phosphorous digestibility was significantly higher for fishmeal and corn gluten meal than all other ingredients. The availability of amino acids was highest for corn gluten meal among the plant-based ingredients, and highest for fishmeal and poultry meal among the animal ingredients. Due to the decreased digestibility of plant-based ingredients with high amounts of carbohydrate, they will not likely be good replacements for fishmeal in cobia diets. Two promising alternate ingredients are poultry meal and corn gluten meal (ZHOU et al., 2004). CHOU et al. (2004) conducted a study in which soybean meal replaced fish meal in increments of $10,20,30,40,50$, and $60 \%$. A significant negative effect was noticed for weight gain, feed conversion, protein efficiency ratio, and net protein utilization when replacement of fishmeal increased from 40 to $50 \%$, indicating that soybean meal can replace up to $40 \%$ of fishmeal without adversely affecting growth or protein utilization. ZHOU et al. (2005) conducted a similar study with diets that would replace $0,10,20,30,40,50$, and $60 \%$ of fishmeal with soybean meal. Protein content in the muscle decreased with increasing inclusion of soybean meal, while deposition of lipid in the liver tended to increase. Weight gain, protein efficiency ratio, and feed conversion ratio were negatively affected when soybean meal replaced greater than $40 \%$ of fishmeal. These results agreed with those of CHOU et al. (2004).

Other forms of alternate dietary protein have been investigated in juvenile cobia. LUNGER et al. (2006) demonstrated that replacement of fishmeal with a minimum of $25 \%$ of an organically certified yeast-based protein could be applicable in juvenile cobia $(11.5 \mathrm{~g})$. Weight 
gain and FCR were significantly affected by the inclusion of the yeast-based protein with decreasing values as inclusion levels rose above $25 \%$ dietary protein, though the diet containing $25 \%$ of the yeast-based protein source had equal weight gain and FCR value as those fish fed the control diet composed of $100 \%$ fishmeal. Additionally, the diet containing $25 \%$ yeast-based protein significantly enhanced plasma protein concentration in the cobia suggesting a possible beneficial immunological impact. LUNGER et al. (2007) undertook a study into the effects of a variety of organic protein supplementation upon growth and feed conversion in juvenile cobia. Weight gain was similar for all fish fed diets containing $40 \%$ of any given alternate protein source. However, fish fed the blended diet with $23 \%$ alternate proteins and $8 \%$ fishmeal exhibited significantly lower weight gain, SGR and FCR values. Cobia fed the diet without any fishmeal did not survive to the end of the study. Biological indices were only significantly affected in the $8 \%$ fishmeal diet. SAADIAH et al. (2011) suggested that PBM could replace $100 \%$ dietary fishmeal without adversely affecting the growth performance, but an optimal replacement level at approximately 60\% was recommended for better growth performance and efficient feed utilization. The present results obtained are similar to previous findings and suggestions with other ingredients used. Growth performance shown by juvenile cobia was very good and indicated that diets containing high inclusion level up to $25 \%$ protein dietary of PBM, SPC, and PBM + Feather meal were well accepted by cobia. These findings suggested that it is possible to use alternatives ingredients in diets for cobia without negative effect on growth performance. However, longer term studies are clearly required to confirm these preliminary results.

In the present study, protein digestibility coefficients over $80 \%$ were obtained for diets from both trials. Cobia was capable of digesting dry matter and crude protein very effectively in almost all of the ingredients tested. These findings agree with previous published studies for cobia that have evaluated FM replacement with plant-based feed ingredients. Previous experiments have been successful in replacing FM in cobia diets (SALZE et al., 2010; WATSON et al., 2014), with ethanol-extracted SPC as the major protein source (27-66\% of the diet). In the present study, special attention was given to the high crude protein digestibility result (90.5\%) attained for the AM4-SPC diet, tested in the recirculating-water indoor tank trial, with a inclusion of $21 \%$ in the formula. Interestingly, the growth and feed performance were not 
significant different compared with the other diets. Moreover, the semi-moist diet had a good CP digestibility coefficient (89.6\%) which was significant different from the the dry diet Aquamar diet $(78.7 \%)$ in the net-cage study. The results of the present study indicated that good quality terrestrial and plant based ingredients can successfully replace fishmeal in the commercial diets for cobia. The preference among diet manufacturers for fishmeal as the major protein source in formulated aquafeeds is easily understood by the high digestibility of crude protein, lipid, and energy, and the high availability of amino acids in fishmeal (ALLAN et al., 2000). Digestibility coefficients of several other ingredients, including poultry meal, meat bone meal, soybean meal, and corn gluten meal, were similar for juvenile cobia to those of fishmeal. The disadvantage of these well-digested high-protein ingredients compared with fishmeal are that the essential amino acid content, amino acid profile, and amino acid availability of these ingredients are generally inferior to fishmeal (Table 2).

The correlation between dietary lipid and body lipid concentrations has been well studied. Too much dietary lipid may result in excessive fat deposition in the visceral cavity and tissues. OTWELL; RICKARDS (1981) suggested that total body-fat content is an important determining factor of consumer acceptance and greater fat deposition occurring in viscera (led by high-energy diets) can reduce the commercial value of the product. In the present study, the hepatosomatic index (HSI) were directly affected by dietary fat level. The HSI increased proportionally with the different lipid levels in the diets, but not significantly different between the experimental diets. In both trials, the Commercial diets resulted in significant higher HSI values, suggesting that these diets are composed of different lipid sources, compared with the experimental diets (fish oil). HSI is an important trait directly affecting the yield in the cobia production (WANG et al., 2005).

When dietary lipid or energy exceeds the capacity of hepatic cells to oxidize fatty acids, increased synthesis and deposition of triacylglycerols in vacuoles result, causing the morphological alteration known as steatosis. Cobia's liver changes in this study were compatible with diagnosis of steatosis or fatty metamorphosis. These findings reflect nutritional and metabolic disturbances in these fish. This type of liver histological alteration due to variations in dietary lipids has been frequently associated with nutritional imbalances in cultured fish (TACON, 1996), including rainbow trout Oncorhynchus mykiss (CABALLERO et al., 2002; 
FIGUEIREDO-SILVA et al., 2005), Atlantic salmon Salmo salar (VEGUSDAL et al., 2005; RUYTER et al., 2006; KJAER et al., 2008), red drum Sciaenops ocelatus (TUCKER et al., 1997), turbot Scophthalmus maximus (BELL et al., 2003), gilthead sea bream Sparus aurata (ALEXIS, 1997; CABALLERO et al., 1999; MONTERO et al., 2001; WASSEF et al., 2007; BENEDITO-PALOS et al., 2008), Atlantic cod Gadus morhua (KJAER et al., 2009), hybrid tilapia Oreochromis niloticus $\times$ O. aureus (GENC et al., 2005), European sea bass Dicentrarchus labrax (SPISNI et al., 1998; MOURENTE et al., 2005), and Eurasian perch Perca uviatilis (BLANCHARD et al., 2008). ROBAINA et al. (1998) found that the use of soybean meal produced peripancreatic deposits of lipid in gilthead sea bream liver, with the fat deposits reduced if the dietary n-3 to n-6 ratio was increased. Replacement of $60 \%$ anchovy oil by soybean meal oil caused severe steatosis in gilthead sea bream, characterized by marked hepatocyte cytoplasmic vacuolation with strong nuclear displacement and lipid infiltration (CABALLERO et al., 2004), which could be related to a lipogenic effect of linoleic acid similar to that described in mammals (IKEDA et al., 1998; IDE, 2000; HALVORSEN et al., 2001). Effects of dietary vegetable oil on fish liver integrity appear to be dependent on the species studied, and also on the type of oil, with marine species more vulnerable to the presence of steatosis signals when vegetable oil, especially those rich in n-6 PUFA, are included in the diet. However, this is not a pathological alteration, since the reversibility after refeeding with fish oil of even acute lipid accumulation, when necrosis or infiltrations are not found, only indicates metabolical imbalance. Nevertheless, the appearance of this morphology is affected by factors other than dietary vegetable oil, such as the level and quality of dietary proteins (MORAIS et al., 2001), dietary lipid levels (CABALLERO et al., 1999; KJAER et al., 2008), lipidic oxidation (ROBERTS, 2002), the presence of phytosterols (MILLER et al., 2008), and temperature (BLANCHARD et al., 2008).

Published literature concerning hepatic steatosis in aquatic organisms, specifically in saltwater fish, is still scarce (ESTRADA et al., 2015). In freshwater fish, the degradation of excess linoleic acid predominantly occurs in peroxisomes. However, it is difficult for saltwater fish to replicate this organelle. This difficulty contributes to the accumulation of fatty acids and development of steatosis. The accumulation of fat in the liver is likely due to physiological or pathological changes. However, there are great variations in the ability of different fish species to 
store lipids, making difficult their study. Steatosis was described in gilthead sea bream (Sparus auratus L.) and sea bass (Dicentrarchus labrax L.), accompanied with high mortality when natural feed was substituted by artificial feed. The severity of the change was proportional to the time that the fish ingested artificial feed (SPINI et al., 1998). Fishmeal supply reduced the severity of steatosis (SHIMADA et al., 2014). In the present study, we noted a similar effect, cobia fed commercial feed presented macrovacuolar steatosis in higher intensity compared with the experimental diets tested. ARAÚJO et al. (2014) obtained similar results when soybean meal was included at 33, 41.5 and 50\% in practical diets for cobia, in order to substitute fishmeal. Also, swollen and pale liver was obtained, similar with those observed in the current study. Lesions that compromise the hepatic parenchyma may lead to clinical signs of insufficiency, such as a delay in growth and a predisposition to infections by opportunistic pathogens such as parasites and bacteria, usually followed by higher mortality (SPINI et al., 1998).

Many studies have been carried out on protein and amino acid nutrition involving a very large number of fish species. A review chapter on protein and amino acid nutrition in fish and shrimp was compiled as part of the National Research Council review entitled Nutrient Requirements of Fish and Shrimp (NRC, 2011). The chapter provides a review of the nutritional biochemistry of proteins and amino acids. The chapter discusses methodological approaches and experiments associated with defining essential amino acid requirements and applying them to practical diet formulation in fish and shrimp. Literature on quantitative amino acid requirements of some commercially marine fish species is briefly summarized in Table 15 .

Quantitative data on amino acid requirements for all EAA are available only for few number of species (NRC, 2011), with apparently high degree of variation between the values (COWEY; 1994; MAMBRINI; KAUSHIK 1995; WILSON; 2002). The best explanation for this apparent variability in EAA requirement data are related to methodology issues (COWEY; 1995): (1) the mode of expression of data (relative to dietary dry matter or dietary CP level, or in absolute terms per unit metabolic mass per day, etc.), (2) the composition and type of diet used and whether the fish were able to reach their near maximum growth potential, (3) the principle used for the estimation of requirement and (4) the statistical method used for analyzing numerical data on dose-response. It is important to note that published research sometimes reports different EAA requirements even for a single species. For example, lysine requirements 
for rainbow trout have been reported to range from 1.3 to $2.7 \%$ (dietary dry matter) (NRC, 2011; Table 15). According to KIM et al. (1992), these differences may be a result of laboratory variations, including fish size, temperature, and experimental diets composition, and/or differences in metabolic losses which may be due in part, to variations in physiological conditions encountered in various experiments or because of genetic differences in the test stock of fish being used. These factors affect the metabolic status of the fish, thereby directly or indirectly influencing the efficiency of protein accretion and growth, and consequently, affecting estimates of nutrient requirements. Thus, EAA requirements can be expected to differ according to the energy needs required to satisfy routine metabolic demands of fish cultured under different conditions. 
Table 15 - Quantitative essential amino acid (\% dietary dry matter, EAA) requirements of some commercial carnivorous fish species and estimative of dietary amino acid requirement of cobia Rachycentron canadum, as based on carcass daily deposition and whole-body amino acid profile methods.

\begin{tabular}{|c|c|c|c|c|c|c|c|c|}
\hline \multirow[b]{2}{*}{ EAA } & \multirow{2}{*}{$\begin{array}{l}\text { Rainbow } \\
\text { Trout }^{1}\end{array}$} & \multirow{2}{*}{$\begin{array}{l}\text { Atlantic } \\
\text { salmon }^{2}\end{array}$} & \multirow{2}{*}{$\begin{array}{l}\text { Japanese } \\
\text { Flounder }^{3}\end{array}$} & \multirow{2}{*}{$\begin{array}{l}\text { Asian Sea } \\
\text { Bass }^{4}\end{array}$} & \multicolumn{4}{|c|}{ Cobia } \\
\hline & & & & & Literature $^{5}$ & $\begin{array}{l}\text { Ogino } \\
(1980)^{6}\end{array}$ & $\begin{array}{l}\text { Arai } \\
(1981)^{7}\end{array}$ & $\begin{array}{l}\text { Arai } \\
(1981)^{8}\end{array}$ \\
\hline Arginine & $1.4-3.0$ & $1.6-2.2$ & $2.0-2.5$ & 1.8 & 2.8 & 3.2 & 1.8 & 3.1 \\
\hline Histidine & $0.5-0.6$ & - & - & - & - & 0.9 & 0.5 & 0.9 \\
\hline Isoleucine & $0.7-1.4$ & - & - & - & - & 2.1 & 1.2 & 2.1 \\
\hline Leucine & $1.1-3.4$ & - & - & - & - & 3.1 & 1.7 & 3.1 \\
\hline Lysine & $1.3-2.7$ & $2.0-2.2$ & $1.5-2.1$ & 2.1 & 2.3 & 4.2 & 2.3 & 4.1 \\
\hline Methionine & $0.4-0.9$ & 0.7 & $1.4-1.5$ & 1.0 & 1.2 & 1.2 & 0.7 & 1.2 \\
\hline Phenylalanine & 0.7 & - & - & - & - & 1.7 & 1.0 & 1.7 \\
\hline Threonine & 1.1 & 1.1 & & & & 2.0 & 1.1 & 2.0 \\
\hline Tryptophan & $0.1-0.3$ & - & - & - & - & 0.9 & 0.5 & 0.8 \\
\hline Valine & $0.8-1.6$ & - & - & - & - & 2.6 & 1.4 & 2.5 \\
\hline Taurine & - & - & - & - & - & 0.4 & 0.2 & 0.4 \\
\hline
\end{tabular}

'Oncorhynchus mykiss: Cho et al., 1992; Chiu et al., 1988; Walton et al., 1986; Fournier et al., 2003; Kim et al., 1992; Jackson; Capper, 1982;

Twibell; Brown, 1997; Rodehutscord et al., 1997; Choo et al., 1991; Walton et al., 1984; Wang et al., 2010; Kim et al., 1992; Cheng et al., 2003; Encarnação et al., 2004; Cowey et al., 1992; Bodin et al.; 2008; Poston; Runsey, 1983; Walton et al, 1986.

${ }^{2}$ Salmo salar: Berge et al., 1997; Lall et al., 1994; Anderson et al, 1993; Espe et al., 2007; Espe et al., 2008.

${ }^{3}$ Paralichthys olivaceus: Alam et al., 2002; Forster; Ogata, 1998; Alam et al., 2000.

${ }^{4}$ Lates calcarifer: Murillo-Gurrea et al., 2001; Coloso et al., 1999.

${ }^{5}$ Rachycentron canadum: Ren et al., 2014; Zhou et al., 2006; Zhou et al., 2007.

${ }^{6}$ Ogino $(1980)$ Daily AA retention $(\%$ dry matter $)=($ final $\%$ of specific AA * final body weight $)$ - (initial \% of specific AA * initial body weight) / number of days.

${ }^{7}$ Arai $(1981)$ EAA requirement $=(\mathrm{A} / \mathrm{E}$ of essential amino acid $*($ lysine requirement $(\%)) /(\mathrm{A} / \mathrm{E}$ ratio of lysine in the final WB $)$; lysine requirement of 2.33 (\% dry matter) estimated by broken-line (Zhou et al., 2007).

${ }^{8}$ Arai (1981) EAA requirement $=(\mathrm{A} / \mathrm{E}$ of essential amino acid * (methionine requirement $(\%)) /(\mathrm{A} / \mathrm{E}$ ratio of methionine in the final WB $)$; methionine requirement of 1.19 (\% dry matter) estimated by broken-line (Zhou et al., 2006).

Dash $=$ not available. 
The original OGINO method assumes that the majority of the ingested EAA are used for tissue protein synthesis and that the whole body amino acid profile is the main determinant of the dietary amino acid requirement profile. Therefore, the EAA values for protein accretion (as \% of dietary protein) shown in Table 9 of this study would equate with the dietary requirement of each EAA for maximal fish growth, according to the OGINO method. However, the amino acid profile laid down in the fish whole body shows a close correlation to the pattern of dietary EAA established by dose-response (COWEY; TACON, 1983; WILSON; POE, 1985). However, this does not mean that the net EAA retentions can be used to quantitate requirements for maximal growth. To obtain these levels of EAA retention, much higher quantities of EAA are actually being fed. This is because only about $30-40 \%$ of dietary nitrogen is normally retained by the growing fish (NRC, 2011). MILLWARD (1994) compared the AA profile required for tissue protein, growth and routine metabolic demands, observing that the AA pattern required for the growth for equivalent amounts of protein is similar to the tissue protein profile itself. However, maintenance profiles (routine metabolic demands) were only similar for the sulfur AA, arginine, histidine and tryptophan, and were slightly lower for threonine, and lower still for lysine, leucine, valine and isoleucine. These results suggest that tissue AA profiles could be used to reasonably predict dietary requirements for the sulfur AA, histidine, tryptophan and arginine, but are less useful for the determination of lysine and the branched chain AA. BOORMAN (1980) showed that for the chick a direct correlation existed between the tissue EAA profile and dietary requirement profile. COWEY; TACON (1981) showed that, this was also true for carp. Neither the method of BOORMAN (1980) or OGINO (1980) take into account the metabolic rate of EAA other than for pattern synthesis in particularly no allowance is made for the maintenance requirement for the AA. However, it is unlikely that maintenance will change the requirement profile (BOORMAN, 1980) and should only have slight influence on the absolute dietary requirements.

The present study estimated the dietary EAA requirements of young cobia based on carcass daily deposition and whole-body amino acid profile methods. These values did not take into account metabolic losses, or the digestibility or efficiencies of utilization of any individual EAA. Lysine and methionine were chosen as the reference EAA in order to estimate the EAA requirements for comparison reasons (ESTRADA et al., 2015). Generally, only lysine is selected 
as the reference amino acid, and there are several reasons for it. First, lysine has only one major function in the animal body and that is for protein tissue deposition, therefore, its requirement is not influenced by other metabolic roles. Second, depending on the fish species and type of ingredients, lysine is usually the most or second most limiting amino acid; thus more is known about the requirements for lysine than other amino acids. Third, the analysis of lysine in feed is usually accomplished without analytical complications (MILES; CHAPMAN, 2008).

When expressed as a percentage of crude protein, the values for methionine and arginine, are generally similar to EAA requirements reported for cobia (ESTRADA et al., 2015). In contrast, the current estimates for lysine requirement are much higher than the reported values for cobia and other marine carnivorous species (NRC, 2011). Similarly, OSTROWSKI; DIVAKARAN (1989) observed higher A/E ratios for lysine, as well as leucine, phenylalanine and arginine, in the dolphin fish, Coryphaena hippurus. These A/E ratios were derived from daily EAA requirements for turnover in muscle, gills and the gastrointestinal tract, based on metabolic demand estimates (FAUCONNEAU; ARNAL, 1983). Interestingly, OSTROWSKI; DIVAKARAN (1989) noted that methionine, an EAA involved in complex metabolic pathways, did not exhibit a high metabolic rate. Similar observations with poultry, showed maintenance profiles for the sulfur AA to be similar to whole-body profiles (FULLER et al., 1989).

Comparing the estimated results of EAA using the two different methods (protein accretion and E/A ratio), an underestimation of the values was noticed when lysine was used as the reference EAA (Figure 18). WILSON (1994) was able to closely predict the EAA requirements for channel catfish by using the quantitative requirement of catfish for lysine that was established by dose response, and deriving the requirements for the other nine EAA by simple proportion using the profile of amino acids in whole body protein. A similar method was used by MOON; GATLIN (1991) to predict the methionine requirement of juvenile red drum, Sciaenops ocellatus, that was confirmed by dose response. Data available today on amino acid requirements do not make a clear distinction between needs for the maintenance and growth components. In the absence of quantitative information on the dietary maintenance needs for cobia, we attempted to estimate the dietary requirements based on its A/E (Table 15). The quantitative EAA requirement values estimated in this way were very close to the average of each of the EAA requirement for the species of carnivorous fish mentioned in Table 15. 
Therefore, until more accurate data is known about the requirements of cobia, the ideal dietary EAA profile may best be estimated by the profile of EAA required for tissue protein accretion, especially during rapid stages of growth (TACON, 1987).

From the actual and many other studies, it appears that the ideal protein would be the one that reflects the whole body EAA profile of the corresponding species. The whole body protein bound amino acid profiles are however very much similar between different species and the amino acids deposited during growth are also similar between different teleosts (Table 16). It has clearly been shown that there is possibly more apparent variability in AA requirement profiles than in the whole body AA profiles of different species (AKIYAMA, 1997). There was a good correlation $\left(R^{2}=0.92\right)$ between the final whole body EAA composition of the cobia from the cage net trial and the average of a large number of sources presented in Table 16.

Table 16 - Whole body amino acid composition of cobia Rachycentron canadum and different fish species (expressed as \% of CP).

\begin{tabular}{lll}
\hline Amino acid & Cobia & Finfish* \\
\hline Arginine & 6.36 & $6.16(0.98)$ \\
Histidine & 1.93 & $2.47(0.63)$ \\
Isoleucine & 4.32 & $4.29(0.92)$ \\
Leucine & 6.32 & $7.20(0.70)$ \\
Lysine & 8.41 & $7.38(0.89)$ \\
Methionine & 2.45 & $2.75(0.45)$ \\
Phenylalanine & 3.52 & $4.10(0.47)$ \\
Threonine & 4.13 & $4.39(0.54)$ \\
Tryptophan & 1.66 & $1.01(0.29)$ \\
Valine & 5.22 & $4.73(0.53)$ \\
Taurine & 0.82 & - \\
Cystine & 2.45 & $0.96(0.26)$ \\
Tyrosine & 2.87 & $3.02(0.62)$ \\
Serine & 3.69 & $4.15(0.47)$ \\
Glycine & 8.35 & $6.81(1.69)$ \\
Aspartic Acid & 8.10 & $9.19(0.85)$ \\
Glutamic Acid & 13.45 & $14.29(2.49)$ \\
Proline & 5.04 & $4.37(1.13)$ \\
Alanine & 6.61 & $6.17(0.82)$ \\
\hline
\end{tabular}

*Data (mean \pm s.d.) from a large number of sources including Wilson; Cowey (1985); Mambrini; Kaushik (1995); Akiyama et al., (1997); and Kim; Lall (2000). 
Whole body $\mathrm{A} / \mathrm{E}$ ratios appear to be suitable indicators of EAA requirements for a number of fish species. In the present study, the highest correlations were observed between whole body $\mathrm{A} / \mathrm{E}$ ratios and dietary $\mathrm{A} / \mathrm{E}$ ratios (in the trash-fish treatment). WILSON (1991) reported reasonable agreement between the EAA requirements for catfish, as estimated using an ideal protein procedure (100\% true digestibility and $100 \%$ biological value), and those determined directly by dose-response experiments.

The daily intake and deposition of EAA of the cobia fed trash-fish are presented in Table 17. In average, $62.7 \%$ of the EAA were retained by the animal, with some variations between each EAA. Histidine and taurine had the lowest EAA retention (35.5 and 45.1\%, respectively), suggesting that these EAA could be involved as substrates for processes other than protein deposition. In addition, tryptophan and arginine had the highest retention $(91.1$ and $74.1 \%$, respectively).

Table 17 - The daily intake (g/fish/day), daily tissue deposition (g/fish/day), and retained quantity (\%) of essential amino acids (EAA) of cobia Rachycentron canadum fed a high-value protein diet for 70 days.

\begin{tabular}{llll}
\hline$E A A$ & $\begin{array}{l}\text { Daily intake } \\
(\mathrm{g} / \text { fish / day })^{\mathrm{a}}\end{array}$ & $\begin{array}{l}\text { Daily deposition } \\
(\mathrm{g} / \text { fish / day })^{\mathrm{b}}\end{array}$ & $\begin{array}{l}\text { Retained } \\
(\%)^{\mathrm{c}}\end{array}$ \\
\hline Arginine & 0.2881 & 0.2135 & 74.1 \\
Histidine & 0.1767 & 0.0628 & 35.5 \\
Isoleucine & 0.2264 & 0.1449 & 64.0 \\
Leucine & 0.3341 & 0.2089 & 62.5 \\
Lysine & 0.4280 & 0.2813 & 65.7 \\
Methionine & 0.1289 & 0.0819 & 63.6 \\
Phenylalanine & 0.1924 & 0.1165 & 60.6 \\
Threonine & 0.2098 & 0.1375 & 65.5 \\
Tryptophan & 0.0644 & 0.0587 & 91.1 \\
Valine & 0.2826 & 0.1749 & 61.9 \\
Taurine & 0.0552 & 0.0249 & 45.1 \\
Average & 0.2170 & 0.1369 & 62.7 \\
\hline
\end{tabular}

${ }^{a}$ Daily EAA intake (g/fish/day) = average feed intake (g/fish/day) * EAA (\%), based on the EAA profile of the trash-fish (sardine Sardinella brasiliensis).

${ }^{\mathrm{b}}$ Daily EAA deposition $(\mathrm{g} / \mathrm{fish} /$ day $)=[$ final EAA $(\%) *$ final body weight $(\mathrm{g})]-[$ initial EAA $(\%) *$ initial body weight $(\mathrm{g})] /$ number of days, based on the EAA profiles of the initial and final body weight, respectively.

${ }^{c}$ EAA retained $(\%)=($ EAA daily deposition / EAA daily intake $) * 100$. 
Overall, the high percentage of EAA retention in the whole body tissue observed in this study, indicated that the trash-fish (composed by sardine) have a good EAA digestibility and availability. The high crude protein digestibility of the trash fish was confirmed comparing both Aquamar and semi moist feed crude protein digestibility (78.7 and 89.6\%, respectively). In order to supply amino acids from protein sources, it must be digested. The nutritional value of a protein depends on the digestibility and availability of amino acids. Digestibility and availability are not synonymous terms. Digestibility refers to the susceptibility of peptide bonds to hydrolysis, while availability refers to the chemical integrity of amino acids, for example, its resistance to processing by heat, high $\mathrm{pH}$, oxidation, etc. (LALL; ANDERSON, 2005). These treatments can limit both digestibility and availability, particularly for lysine, methionine, threonine and tryptophan. Both parameters must be considered to define the nutritional value of proteins. Availability of any nutrient is the result of two processes: digestion and utilization. Thus, amino acid availability will be the result of protein hydrolysis and absorption of the products and the retention of absorbed amino acids. Most high quality fishmeals are considered to be a complete source of amino acids for fish on the basis of published analytical data (NRC, 2011). Animal meat by-products have surplus lysine and arginine but are sometimes deficient in sulfur amino acids and tryptophan. Milk protein available as dried whey is a good source of lysine and tryptophan but is deficient in arginine. Oilseed proteins show characteristically different patterns and they are generally deficient in lysine with the exception of soybean meal. Blood meal contains appreciable amounts of other amino acids, however, it is deficient in isoleucine. Corn gluten meal contains high amounts of isoleucine but has low levels of lysine and tryptophan (ESTRADA et al., 2015). Fishmeal is still an important source of protein in the diets of many intensively reared aquaculture species.

The main function of dietary protein is to provide amino acids and protein quality is measured by both the nitrogen content and amino acid constituents of the protein (NRC, 2011). Therefore, bioavailability of amino acids is generally defined as the proportion of ingested dietary amino acids that are absorbed in a chemical form that renders these amino acids potentially suitable for metabolism or protein synthesis (NRC, 2011). The process of turnover of amino acids, sequentially cycling through protein via synthesis degradation, is extremely specific at different tissue levels, but overall, fish catabolize $40-50 \%$ of body proteins to be returned to the pool of precursors and reused for synthesis (ESTRADA et al., 2015). 
The average temperature, body weight and daily feed intake of cobia fed the trash-fish treatment during 70 days is presented in Figure 26. It was noticed that the Trash-fish intake tends to increase along the experimental period, with some variation between the days. The average intake was $8.27 \mathrm{~g}$ per fish per day (\%, dry matter). The body weight (growth) increased more than five times during the 70 days, and this tendency was not followed by the feed intake, suggesting that the nutrients assimilation was very high, specially by the end of the trial (Figure 26). In addition, it was observed that the feed intake followed the water temperature trend. Although the efficiency of AA utilization for accretion is relatively constant, the efficiency may not be optimum when protein accretion (growth rate) is high and it is continuously decreasing with an increase in feed intake (LALL; ANDERSON, 2005).

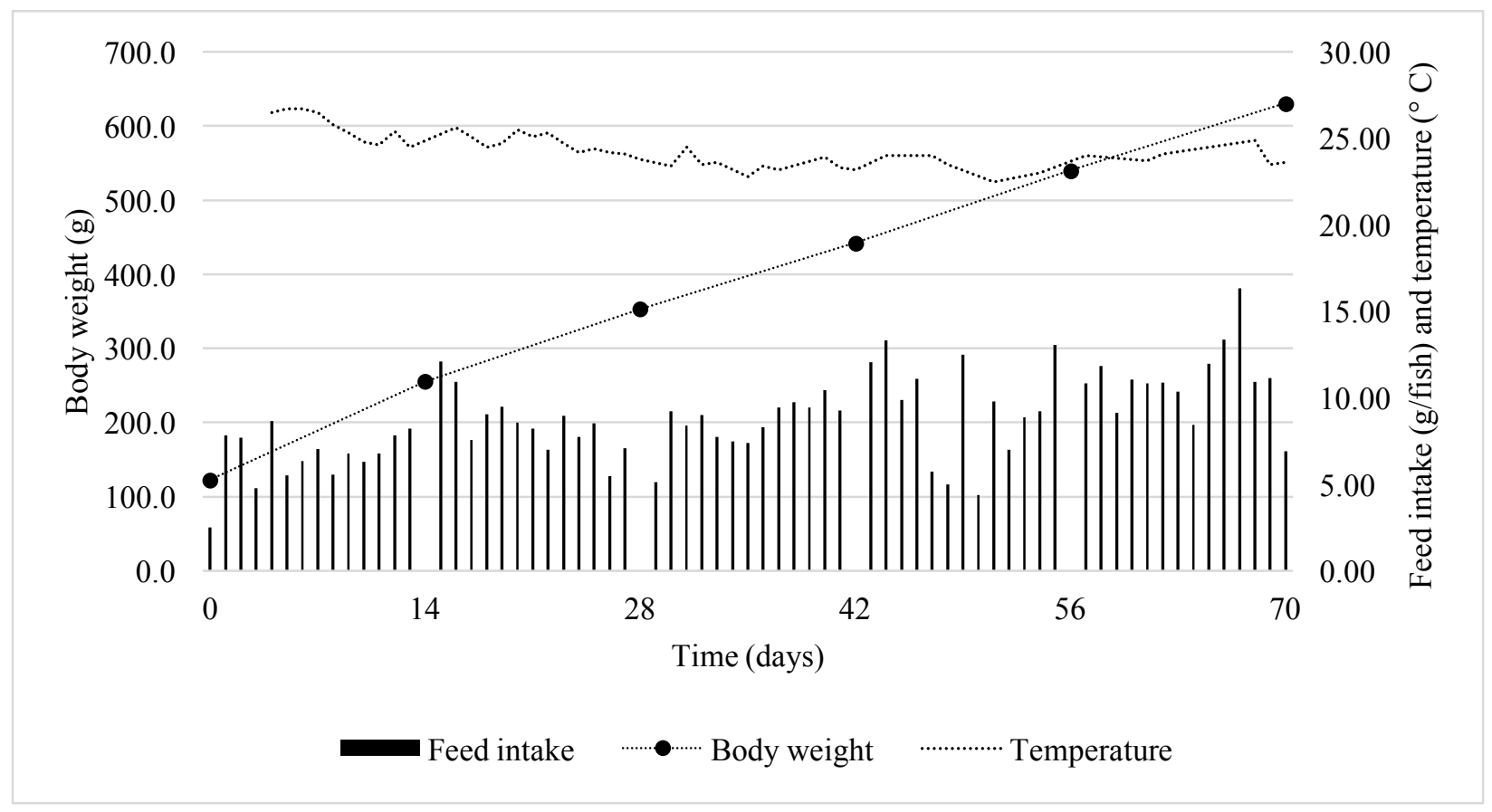

Figure 26 Average body weight (g/fish), daily feed intake (dry matter basis, $g / f i s h)$, and water temperature $\left({ }^{\circ} \mathrm{C}\right)$ in the net-cage system, of juvenile cobia Rachycentron canadum fed trash-fish for 70 days.

Plant proteins are probably the most widely used alternative to fishmeal in carnivorous fish diets, but they present some problems, including lower crude protein levels, palatability issues, amino acid deficiencies and the occurrence of antinutritional factors such as trypsin inhibitors (FRANCIS et al., 2001). Taurine is not generally considered to be an essential amino acid for fish. It is a free amino acid that is present in large quantities in various tissues of marine 
fishes (PARK et al., 2002). In mammals, taurine plays important roles in osmoregulation, bile acid conjugation, membrane stabilization, hormone release, modulation of neurotransmitters, and antioxidation (STURMAN, 1988; HUXTABLE, 1992). Carnivorous fishes in the wild consume large quantities of taurine since it is highly abundant in animal tissues, but this does not apply when aquafeeds contain large amounts of plant protein sources, which are naturally low in taurine. Therefore, it may be necessary to supplement these diets with taurine and other amino acids to acquire benefits.

In the recirculated-water tank feeding trial, supplementing taurine at $0.5 \%$ dry weight to diets that contained variable amounts of protein sources replacing $50 \%$ of fishmeal, resulted in better weight gain and generally exhibited better feed efficiency ratios (although not significant) than animals fed the unsupplemented diet AM6-TAU. As reviewed recently by SALZE; DAVIS (2015), the capacity of aquaculture fish to biosynthesize taurine depends on the species, with most marine species requiring taurine in the diet. Although the underlying physiological processes are not yet completely understood, recent studies have shown that taurine supplementation improves the growth of many marine fish species such as Japanese flounder Paralichthys olivaceus (PARK et al., 2002; KIM et al., 2003; KIM et al., 2005), sea bream Pagrus major (MATSUNARI et al., 2008), yellowtail Seriola quinqueradiata (MATSUNARI, et al., 2005; TAKAGI et al., 2006), cobia Rachycentron canadum (LUNGER et al., 2007), and Florida pompano Trachinotus carolinus (ROSSI; DAVIS, 2012).

Evidence from the present study indicates that cobia require taurine supplementation when fed diets containing some levels of animal and plant-based protein sources. MARTINEZ et al. (2004) reported that sea bass also may need dietary taurine supplementation under certain feeding practices. Rainbow trout that were fed a plant-based diet needed taurine supplemented at $0.5 \%$ dry diet in order to match the growth of fish fed a fish meal-based control diet (GAYLORD et al., 2006). KIM et al. (2003) reported that juvenile olive flounder required taurine supplementation, whereas fingerling olive flounder did not. Optimal levels of taurine supplementation were suggested to be $0.15 \%$ (KIM et al., 2005) or $0.15-0.20 \%$ (PARK et al., 2001). Results thus indicate that taurine supplementation is necessary for some fish species. This could be particularly true for marine species, since taurine plays a critical role in osmoregulation and typically comprises more than $50 \%$ of the free amino acid pool (LOMBARDINI et al., 
1979). Fish raised in seawater may have a greater demand for dietary taurine than fish held in fresh water and a ability to convert cysteine to taurine may be based on their environmental salinity adaptation (GAYLORD et al., 2006). Therefore, the osmotic stabilization provided by taurine may be related to its effects on growth and the fact that supplementation to diets improves growth in numerous species (KIM et al., 2003). Some species may be unable or poor at synthesizing taurine de novo from cysteine. This result may be due to the activity level of Lcysteinesulphinate decarboxylase, which in turn might be influenced by the natural feeding habits of a particular species or from previous feeding history (GAYLORD et al., 2006). Carnivorous fishes therefore, may be less able to synthesize taurine due to their naturally high intake, while herbivorous/omnivorous fish may be more capable of such synthesis due to the lack of taurine in their natural diets. When $S$. quinqueradiata and P. major were fed a taurinedeficient diet they developed "green liver syndrome" and exhibited poor growth performances compared to animals receiving taurine-rich diets (TAKAGI et al., 2006). Taurine deficiency explains the reduction in growth performance when including high levels of taurine-poor ingredients in fish feeds. By supplementing plant-based diets with taurine, growth performance was restored (CHATZIFOTIS et al., 2008; LUNGER et al., 2007).

Species with rapid growth rates, such as cobia, may also experience an increased demand on the de novo synthesis of taurine which cannot be met, especially when fishmeal is replaced in diets by plant protein sources lacking of taurine. When a non-essential amino acid, such as taurine, is added to diets, it may be possible to conserve essential amino acids as well (COWEY, 1994), which could lead to improved growth rates. An explanation for these results could be that taurine alone was able to allow cobia to conserve the small amount of methionine and tryptophan that was present in the unsupplemented diets, thereby improving growth rates.

These findings could dramatically change the amount and types of alternate proteins that can be incorporated into diets for juvenile cobia and decrease the industry's dependence on fishmeal supplies for the continued aquaculture of cobia. The results from this study also argue for the importance of determining quantitative amino acid requirements for cobia, many of which are presently undetermined. 


\subsection{Conclusions}

The results from both trials concluded that the cobia requires practical diets with high levels of crude protein and lipids, and the inclusion of alternative plant-based and terrestrial animal protein sources is possible. Also, the outcome of both trials suggest the need for nutritional improvement of existing commercial diets currently employed for cobia farming in Brazil.

A general consequence of EAA estimation presented is that alternate methods based on whole body protein amino acid composition, although useful as guidelines in establishing EAA profiles to formulate practical or experimental diets for fish species whose EAA are partially or totally unknown, should be applied with caution since they do not provide "true" amino acid requirement values. The quantitative EAA requirement values estimated by the protein accretion method was highly correlated to the average of each of the EAA requirement for the species of carnivorous fish reported in the literature, and could be recommended for formulation of commercial feeds for cobia. Using body amino acids profile to set basis for dietary amino acids profile and requirements is a viable technique and may bring additional benefits of formulating diets eliciting higher feeding efficiency and reduced nutrient loss and waste and metabolites excretion.

Finally, to ensure the applicability and rapid transfer of future research data to commercial farms, wherever possible, nutrition experiments with cobia (based on the use of practical diets) should be conducted in-situ on comparable marine fish farms, and the data generated should also be evaluated from an economic viewpoint. In addition, long term feeding trials are required from fingerling to market size with full nutritional and economic evaluation of results and fish quality parameters. 


\subsection{References}

AKIYAMA, T.; OOHARA, I.; YAMAMOTO, T. Comparison of Essential Amino Acid Requirements with A/E Ratio among Fish Species (Review Paper). Fisheries Science, v. 63, n. 6, p. 963-970. 1997.

ALAM, M. D.; TESHIMA, S. I.; ISHIKAWA, M.; KOSHIO, S. Methionine requirement of juvenile Japanese flounder Paralichthys olivaceus. Journal of the World Aquaculture Society, v. 31(4), p. 618-626. 2000.

ALAM, M. S.; TESHIMA, S. I.; KOSHIO, S.; ISHIKAWA, M. Arginine requirement of juvenile Japanese flounder Paralichthys olivaceus estimated by growth and biochemical parameters. Aquaculture, v. 205(1), p. 127-140. 2002

ALEXIS, M. N. Fish meal and fish oil replacers in Mediterranean marine fish diets. Cahiers Options Mediterraneennes, v. 22, p. 183-204. 1997

ALLAN, G.L.; PARKINSON, S.; BOOTH, M. A.; STONE, D. A. J.; ROWLAND, S. J.; FRANCES, J.; WARNER-SMITH, R. Replacement of fish meal in diets for Australian silver perch, Bidyanus bidyanus: I. Digestibility of alternative ingredients. Aquaculture, v. 186 , p. 293-310. 2000.

ANDERSON, J. S.; LALL, S. P.; ANDERSON, D. M.; MCNIVEN, M. A. Quantitative dietary lysine requirement of Atlantic salmon (Salmo salar) fingerlings. Canadian Journal of Fisheries and Aquatic Sciences, v. 50(2), p. 316-322. 1993.

ARAI, S. A purified test diet for coho salmon, Oncorhynchus kisutch, fry. Bulletin of the Japanese Society of Scientific Fisheries, v. 47, p. 547-550. 1981.

BELL, J. G.; MCGHEE F.; CAMPBELL, P. J.; SARGENT, J.R. Rapeseed oil as an alternative to marine fish oil in diets of post-smolt Atlantic salmon (Salmo salar): changes in flesh fatty acid composition and effectiveness of subsequent fish oil "wash out". Aquaculture, v. 218 , p. $515-528.2003$.

BENEDITO-PALOS, L.; NAVARRO, J. C.; SITJÀ-BOBADILlA, A.; BELL, J. G.; KAUSHIK, S.; PÉREZ-SÁNCHEZ, J. High levels of vegetable oils in plant protein-rich diets fed to gilthead sea bream (Sparus aurata L.): growth performance, muscle fatty acid profiles and histological alterations of target tissues. British Journal of Nutrition, v. 100(05), p. 992-1003. 2008.

BENETTI, D. D.; O'HANLON, B.; RIVERA, J. A.; WELCH, A. W.; MAXEY, C.; ORHUN, M. R. Growth rates of cobia (Rachycentron canadum) cultured in open ocean submerged cages in the Caribbean. Aquaculture, v. 302(3), p. 195-201. 2010.

BENETTI, D. D.; ORHUN, M. R.; SARDENBERG, B.; O'HANLON, B.; WELCH, A.; HOENIG, R.; ZINK, I.; RIVERA, J. A.; DENLINGER, B.; BACOAT, D.; PALMER, K; 
CAVALIN, F. Advances in hatchery and grow-out technology of cobia Rachycentron canadum (Linnaeus). Aquaculture Research, v. 39, p. 701-711. 2008.

BERGE, G. E.; LIED, E.; SVEIER, H. Nutrition of Atlantic salmon (Salmo salar): the requirement and metabolism of arginine. Comparative Biochemistry and Physiology Part A: Physiology, v. 117, n. 4, p. 501-509. 1997.

BLANCHARD, G.; GARDEUR, J. N.; MATHIS, N.; BRUN-BELLUT, J.; KESTEMONT, P. Ultrastructural features of hepatocytes in cultured Eurasian perch (Perca fluviatilis L.) as affected by nutritional and husbandry conditions. British journal of nutrition, 100(02), 317-331. 2008.

BLANCHARD, G.; MAKOMBU, J. G.; KESTEMONT, P. Influence of different dietary 18: 3n3/18: 2 n-6 ratio on growth performance, fatty acid composition and hepatic ultrastructure in Eurasian perch, Perca fluviatilis. Aquaculture, v. 284, n. 1, p. 144-150. 2008.

BODIN, N.; MAMBRINI, M.; WAUTERS, J. B.; ABBOUDI, T.; OOGHE, W.; LE BOULENGE, E., ROLLIN, X. Threonine requirements for rainbow trout (Oncorhynchus mykiss) and Atlantic salmon (Salmo salar) at the fry stage are similar. Aquaculture, v. 274(2), p. 353-365. 2008.

BOORMAN, K. N. Dietary constraints on nitrogen retention. In protein deposition in animals (P.S. Battery and D. B. Lindsey. Eds.). Butterworths London, p. 147-166. 1980.

BRIGGS, J. C. Fishes of worldwide (circumtropical) distribution. Copeia, p. 171-180. 1960.

BROTONS-MARTINEZ, J.; CHATZIFOTIS, S.; DIVANACH, P.; TAKEUCHI, T. Effect of dietary taurine supplementation on growth performance and feed selection of sea bass Dicentrarchus labrax fry fed with demand-feeders. Fisheries Science, v. 70(1), p. 74-79. 2004.

BROWN, M. L. Using whole-body amino acid patterns and quantitative requirements to rapidly develop diets for new species such as striped bass, Morone saxatilis. Journal of Applied Ichthyology, v. 11, p. 342-346. 1995.

BUENTELLO, J. A.; GATLIN, D. M. The dietary arginine requirement of channel catfish (Ictalurus punctatus) is influenced by endogenous synthesis of arginine from glutamic acid. Aquaculture, v. 188(3), p. 311-321. 2000.

CABALLERO, M. J.; LOPEZ-CALERO, G.; SOCORRO, J.; ROO, F. J.; IZQUIERDO, M. S.; FERNANDEZ, A. J. Combined effect of lipid level and fish meal quality on liver histology of gilthead sea bream (Sparus aurata). Aquaculture, v. 179, p. 277-290. 1999.

CABAllerO, M. J.; OBACH, A.; ROSENLUND, G.; MONTERO, D.; GISVOLD, M.; IZQUIERDO, M. S. Impact of different dietary lipid sources on growth, lipid 
digestibility, tissue fatty acid composition and histology of rainbow trout, Oncorhynchus mykiss. Aquaculture, v. 214, p. 253-271. 2002.

CHATZIFOTIS, S., POLEMITOU, I., DIVANACH, P., ANTONOPOULOU, E. Effect of dietary taurine supplementation on growth performance and bile salt activated lipase activity of common dentex, Dentex dentex, fed a fish meal/soy protein concentrate-based diet. Aquaculture, v. 275(1), p. 201-208. 2008.

CHENG, Z. J.; HARDY, R. W.; USRY, J. L. Effects of lysine supplementation in plant proteinbased diets on the performance of rainbow trout (Oncorhynchus mykiss) and apparent digestibility coefficients of nutrients. Aquaculture, v. 215, n. 1, p. 255-265. 2003.

CHI, S., T. B.; DONG, X.; YANG, Q.; LIU, H. Effects of supplemental coated or crystalline methionine in low-fishmeal diet on the growth performance and body composition of juvenile cobia Rachycentron canadum (Linnaeus). Chinese Journal of Oceanology and Limnology, v. 32, p. 1297-1306. 2014.

CHIU, Y. N.; AUSTIC, R. E.; RUMSEY, G. L. Effect of feeding level and dietary electrolytes on the arginine requirement of rainbow trout (Salmo gairdneri). Aquaculture, v. 69, n. 1, p. 79-91. 1988.

CHO, C. Y. Feeding systems for rainbow trout and other salmonids with reference to current estimates of energy and protein requirements. Aquaculture, v. 100, n. 1, p. 107-123. 1992.

CHOU, R. L.; HER, B. Y.; SU, M. S.; HWANG, G.; WU, Y. H.; CHEN, H. Y. Substituting fish meal with soybean meal in diets of juvenile cobia Rachycentron canadum. Aquaculture, v. 229, p. 325-333. 2004.

CHOU, R. L.; SU, M. S.; CHEN, H. Y. Optimal dietary protein and lipid levels for juvenile cobia (Rachycentron canadum). Aquaculture, v. 193, p. 81-89. 2001.

COLOSO, R. M.; MURILlO-GURREA, D. P.; BORLONGAN, I. G.; CATACUTAN, M. R. Sulphur amino acid requirement of juvenile Asian sea bass Lates calcarifer. Journal of Applied Ichthyology, v. 15(2), p. 54-58. 1999.

COWEY, C. B. Amino acid requirements of fish: a critical appraisal of present values. Aquaculture, v. 124, p. 1-11. 1994.

COWEY, C. B. Nutrition: estimating requirements of rainbow trout. Aquaculture, v. 100, n. 1, p. 177-189. 1992.

COWEY, C. B.; TACON, A. G. J. Fish nutrition - relevance to invertebrates. In: Proceedings of the Second International Conference on Aquaculture Nutrition (G.D. Pruder, C.J. Langdon and D.E. Conklin, editors). Rehoboth Beach, Delaware. Special Publication No. 2, World Mariculture Society, Louisiana State University, Baton Rouge. pp. 13-30. 1983. 
CRAIG, S. R.; SCHWARZ, M. H.; MCLEAN, E. Juvenile cobia (Rachycentron canadum) can utilize a wide range of protein and lipid levels without impacts on production characteristics. Aquaculture, v. 261(1), p. 384-391. 2006.

DE BEZERRA, T. R. Q.; DOMINGUES, E. C.; MAIA FILHO, L. F. A.; ROMBENSO, A. N.; HAMILTON, S.; CAVALLI, R. O. Economic analysis of cobia (Rachycentron canadum) cage culture in large-and small-scale production systems in Brazil. Aquaculture International, p. 1-14. 2015.

DENSON, M.R.; STUART K.R.; T.I.J. SMITH. Effects of salinity on growth, survival, and selected hematological parameters of juvenile cobia Rachycentron canadum. Journal of the World Aquaculture Society, v. 34, p. 496-504. 2003.

ENCARNAÇÃO, P.; DE LANGE, C.; RODEHUTSCORD, M.; HOEHLER, D.; BUREAU, W.; BUREAU, D. P. Diet digestible energy content affects lysine utilization, but not dietary lysine requirements of rainbow trout (Oncorhynchus mykiss) for maximum growth. Aquaculture, v. 235(1), p. 569-586. 2004.

ESPE, M.; HEVRØY, E. M.; LIASET, B.; LEMME, A.; EL-MOWAFI, A. Methionine intake affect hepatic sulphur metabolism in Atlantic salmon, Salmo salar. Aquaculture, v. 274(1), p. 132-141. 2008.

ESPE, M.; LEMME, A.; PETRI, A.; EL-MOWAFI, A. Assessment of lysine requirement for maximal protein accretion in Atlantic salmon using plant protein diets. Aquaculture, v. 263(1), p. 168-178. 2007.

ESTRADA, U. R.; YASUMARU, F. A.; TACON, A. G. J.; LEMOS, D. Cobia (Rachycentron canadum): A Selected Annotated Bibliography on Aquaculture, General Biology and Fisheries 1967-2015. Reviews in Fisheries Science \& Aquaculture, v. 24 (1), p. 1-97. 2015.

FAO, 2014. State of World Fisheries and Aquaculture 2014. FAO, Rome, Italy. 2014.

FAO, 2016. Fisheries and aquaculture software. FishStatJ - software for fishery statistical time series. In: FAO Fisheries and Aquaculture Department [online]. Rome. Released March 2016. Available at http://www.fao.org/fishery/statistics/software/fishstatj/en. 2016.

FAUCONNEAU, B.; ARNAL, M. Leucine metabolism in trout: influence of temperature. Comparative Biochemistry and Physiology Part A, v. 82, p. 435-445. 1983.

FAULK, C. K.; HOLT, G. J. Lipid nutrition and feeding of cobia Rachycentron canadum larvae. Journal of the World Aquaculture Society, v. 34, p. 368-378. 2003.

FORSTER, I.; OGATA H. Y. Lysine requirement of juvenile Japanese flounder Paralichthys olivaceus and juvenile red sea bream Pagrus major. Aquaculture, v. 161, p. 131-142. 1998. 
FOURNIER, V.; GOUILLOU-COUSTANS, M. F.; METAILlER, R.; VACHOT, C.; MORICEAU, J.; LE DELLIOU, H.; KAUSHIK, S. J. Excess dietary arginine affects urea excretion but does not improve $\mathrm{N}$ utilisation in rainbow trout Oncorhynchus mykiss and turbot Psetta maxima. Aquaculture, v. 217(1), p. 559-576. 2003.

FRANCIS, G.; MAKKAR, H. P.; BECKER, K. Antinutritional factors present in plant-derived alternate fish feed ingredients and their effects in fish. Aquaculture, v. 199, n. 3, p. 197227. 2001.

FRANKS, J. S.; WARREN, J. R.; BUCHANAN, M. V. Age and growth of cobia, Rachycentron canadum, from the northeastern Gulf of Mexico. Fishery Bulletin, v. 97, p. 459-470. 1999.

FULLER, M. F.; STON, R. M.; BAIRD, B. A. AND ATKINSON, T. The optimal amino acid supplementation. British Journal of Nutrition, v. 41, p. 321-331. 1979.

GABER M. M.; ZAKI M. A.; NOUR A. M.; SALEM, M. EL-S. Amino Acid Requirements of Sea Bass (Dicentrarchus labrax). International Journal of Agricultural Sciences and Natural Resources, v. 2, n. 2, p. 40-45. 2015.

GAYLORD, T. G.; TEAGUE, A. M.; BARROWS, F. T. Taurine Supplementation of all-plant protein diets for rainbow trout (Oncorhynchus mykiss). Journal of the World Aquaculture Society, v. 37, n. 4, p. 509-517. 2006.

GENC, E.; YILMAZ, E.; AKYURT, I. Effects of dietary fish oil, soy-acid oil, and yellow grease on growth and hepatic lipidosis of hybrid tilapia fry. Israeli Journal of AquacultureBamidgeh, v. 57, n. 2, p. 90-96. 2005.

GENG, X.; DONG, X. H.; TAN, B. P.; YANG, Q. H.; CHI, S. Y.; LIU, H. Y.; LIU, X. Q. Effects of dietary chitosan and Bacillus subtilis on the growth performance, non-specific immunity and disease resistance of cobia, Rachycentron canadum. Fish and Shellfish Immunology, v. 31(3), p. 400-406. 2011.

GENG, X.; DONG, X. H.; TAN, B. P.; YANG, Q. H.; CHI, S. Y.; LIU, H. Y.; LIU, X. Q. Effects of dietary probiotic on the growth performance, non-specific immunity and disease resistance of cobia, Rachycentron canadum. Aquaculture Nutrition, v. 18(1), p. 46-55. 2012.

GLENCROSS, B. A comparison of the digestibility of diets and ingredients fed to rainbow trout (Oncorhynchus mykiss) or barramundi (Lates calcarifer)-the potential for inference of digestibility values among species. Aquaculture Nutrition, v. 17, n. 2, p. e207-e215. 2011.

GURURE, R.; ATKINSON, J.; MOCCIA, R.D. Amino acid composition of Arctic charr, Salvelinus alpinus (L.) and the prediction of dietary requirements for essential amino acids. Aquaculture Nutrition, v. 13, p. 266-272. 2007. 
HALVORSEN, B., RUSTAN, A. C.; MADSEN, L.; RESELAND, J.; BERGE, R. K.; SLETNES P.; CHRISTIANSEN, E. N. Effects of long-chain monounsaturated and n-3 fatty acids on fatty acid oxidation and lipid composition in rats. Annals of Nutrition \& Metabolism, v. 45, p. 30-37. 2001.

HARDY, R. W.; TACON, A. G. Fish meal: historical uses, production trends and future outlook for sustainable supplies. Responsible Marine Aquaculture, p. 311-325. 2002.

HER, B. Y.; CHOU, R. L.; CHEN, T. I.; SU, M. S; LIAO, I. C. Effects of protein/energy ratio on growth of juvenile cobia Rachycentron canadum. Asian Fisheries Forum, Kaohsiung (Taiwan), p. 25-30. 2001.

HUXTABLE, R. J. Physiological actions of taurine. Physiological reviews, v. 72, n. 1, p. 101163. 1992.

IDE T. Effect of dietary alpha-linolenic acid on the activity and gene expression of hepatic fatty acid oxidation enzymes. Biofactors, v. 13, p. 9-14. 2000.

IKEDA I.; CHA J. Y.; YANAGITA, T.; NAKATANI, N.; OOGAMI, K.; IMAIZUMI, K.; YAZAMA, K. Effects of dietary alpha-linolenic, eicosapentaenoic and docosahexaenoic acids on hepatic lipogenesis and b-oxidation in rats. Bioscience Biotechnology and Biochemistry, v. 62, p. 675-680. 1998.

JACKSON, A. J.; CAPPER, B. S. Investigations into the requirements of the tilapia Sarotherodon mossambicus for dietary methionine, lysine and arginine in semi-synthetic diets. Aquaculture, v. 29, n. 3-4, p. 289-297. 1982.

JAUNCEY, K.; TACON, J. G. A.; JACKSON, A. J. The quantitative essential amino acid requirements of Orechromis mossambicus. In: International Symposium on Tilapia in Aqua. Israel, 328-337. 1983.

KAISER, J.; HOLT, G. J. Cobia: A new species for aquaculture in the U.S. World Aquaculture 35, 12-14. 2004.

KAPETSKY, J. M.; AGUILAR-MANJARREZ, J.; JENNESS, J. A global assessment of offshore mariculture potential from a spatial perspective. FAO fisheries and aquaculture technical paper no. 549. FAO, Rome.2013.

KAUSHIK S. J.; BREQUE, J.; BLANC, D. Requirements for protein and essential amino acids and their utilization by Siberian sturgeon (Acipenser baeri). In: Acipenser. Actes du colloque (ed. by P.Williot), pp. 25-39. Cemagref, Bordeaux, France. 1991.

KIM, J. D.; LALL, S. P. Amino acid composition of whole body tissue of Atlantic halibut (Hippoglossus hippoglossus), yellowtail flounder (Pleuronectes ferruginea) and Japanese flounder (Paralichthys olivaceus). Aquaculture, v. 187, n. 3, p. 367-373. 2000. 
KIM, K. I; KAYES, T. B.; AMUNDSON, C. H. Requirements for lysine and arginine by rainbow trout (Oncorhynchus mykiss). Aquaculture, v. 106, n. 3, p. 333-344, 1992.

KIM, K. I.; KAYES, T. B.; AMUNDSON, C. H. Requirements for sulfur amino acids and utilization of D-methionine by rainbow trout (Oncorhynchus mykiss). Aquaculture, v. 101, n. 1, p. 95-103. 1992.

KIM, S. K.; TAKEUCHI, T.; AKIMOTO, A.; FURUITA, H.; YAMAMOTO, T.; YOKOYAMA, M.; MURATA, Y. Effect of taurine supplemented practical diet on growth performance and taurine contents in whole body and tissues of juvenile Japanese flounder Paralichthys olivaceus. Fisheries Science, v. 71. 2005.

KIM, S. K.; TAKEUCHI, T.; YOKOYAMA, M.; MURATA, Y.; KANENIWA, M.; SAKAKURA, Y. Effect of dietary taurine levels on growth and feeding behavior of juvenile Japanese flounder Paralichthys olivaceus. Aquaculture, v. 250, p. 765-774. 2005.

KJAER, M. A.; TODORCEVIC, M.; TORSTENSEN, B. E.; VEGUSDAL, A.; RUYTER, B. Dietary n-3 HUFA affects mitochondrial fatty acid beta-oxidation capacity and susceptibility to oxidative stress in Atlantic salmon. Lipids, v. 43(9), p. 813-827. 2008.

KJAER, M. A.; VEGUSDAL, A.; GJØEN, T.; RUSTAN, A. C.; TODORČEVIĆ, M.; RUYTER, B. Effect of rapeseed oil and dietary n-3 fatty acids on triacylglycerol synthesis and secretion in Atlantic salmon hepatocytes. Biochimica et Biophysica Acta (BBA)Molecular and Cell Biology of Lipids, v. 1781(3), p. 112-122. 2008.

KNOPF, K.; STURMAN, J. A.; ARMSTRONG, M.; HAYES, K. C., 1978. Taurine. An essential nutrient for the cat. Journal of Nutrition, v. 108, p. 773-778.

KWANYUEN, P., BURTON, J.W. A Modified Amino Acid Analysis Using PITC Derivatization for Soybeans with Accurate Determination of Cysteine and Half- Cystine. Journal of the American Chemical Society, v. 87, p. 127-132. 2010.

LALL, S. P.; ANDERSON, S. Amino acid nutrition of salmonids: dietary requirements and bioavailability. Cahiers Options Méditerranéennes, v. 63, p. 73-90. 2005.

LALL, S. P.; KAUSHIK, S. J.; LE BAIL, P. Y.; KEITH, R.; ANDERSON, J. S.; PLISETSKAYA, E. Quantitative arginine requirement of Atlantic salmon (Salmo salar) reared in sea water. Aquaculture, v. 124(1-4), p. 13-25. 1994.

LiAO, I. C., HUANG, T. S., TSAI, W. S., HSUEH, C. M., CHANG, S. L., LEANO, E. M. Cobia culture in Taiwan: current status and problems. Aquaculture, v. 237, p. 155-165. 2004.

LOMBARDINI, J. B. Effects of taurine on calcium ion uptake and protein phosphorylation in rat retinal membrane preparations. Journal of neurochemistry, v. 45, n. 1, p. 268-275. 1985. 
LOMBARDINI, J. B.; PANG, P. K. T.; GRIFFITH, R. W. Amino acids and taurine in intracellular osmoregulation in marine animals. Occasional Papers of the California Academy of Sciences, v.134, p. 160-171. 1979.

LUNGER, A. N.; CRAIG, S. R.; MCLEAN, E. Replacement of fish meal in cobia (Rachycentron canadum) diets using an organically certified protein. Aquaculture, v. 257(1), p. 393-399. 2006.

LUNGER, A. N.; MCLEAN, E.; CRAIG, S. R. The effects of organic protein supplementation upon growth, feed conversion and texture quality parameters of juvenile cobia (Rachycentron canadum). Aquaculture, v. 264, n. 1, p. 342-352. 2007.

LUNGER, A. N.; MCLEAN, E.; GAYLORD, T. G.; KUHN, D.; CRAIG, S. R. Taurine supplementation to alternative dietary proteins used in fish meal replacement enhances growth of juvenile cobia (Rachycentron canadum). Aquaculture, v. 271(1), p. 401-410. 2007.

MAMBRINI, MURIEL; KAUSHIK, S. J. Indispensable amino acid requirements of fish: correspondence between quantitative data and amino acid profiles of tissue proteins. Journal of Applied Ichthyology, v. 11, n. 3-4, p. 240-247. 1995.

MARTINEZ, J. B.; CHATZIFOTIS, S.; DIVANACH, P.; TAKEUCHI, T. Effect of dietary taurine supplementation on growth performance and feed selection of sea bass Dicentrarchus labrax fry fed with demand-feeders. Fisheries Science, v. 70, p. 74-79. 2004.

MATSUNARI, H., FURUITA, H., YAMAMOTO, T., KIM, S. K., SAKAKURA, Y., \& TAKEUCHI, T. Effect of dietary taurine and cystine on growth performance of juvenile red sea bream Pagrus major. Aquaculture, v. 274(1), p. 142-147. 2008.

MATSUNARI, H.; TAKEUCHI, T.; TAKAHASHI, M.; MUSHIAKE, K. Effect of dietary taurine supplementation on growth performance of yellowtail juveniles Seriola quinqueradiata. Fisheries Science, v. 71, p. 1131-1135. 2005.

MEYER, G. H., FRANKS, J. S. Food of cobia, Rachycentron canadum, from the northcentral Gulf of Mexico. Gulf Research Reports, v. 9, p. 161-167. 1996.

MILES, R. D.; CHAPMAN, F. A. The concept of ideal protein in formulation of aquaculture feeds. Department of Fisheries and Aquatic Sciences, University of Florida, USA. 2008.

MILLER, M. R.; NICHOLS, P. D.; CARTER, C. G. N-3 oil sources for use in aquaculture alternatives to the unsustainable harvest of wild fish. Nutrition Research Reviews, v. 21(2), p. 85- 96. 2008.

MILLWARD, J. Can we define indispensable amino acid requirement and assess protein quality in adults? Journal of Nutrition, v. 124, p. 1509S-1516S. 1994. 
MONTERO, D.; ROBAINA, L. E.; SOCORRO, J.; VERGARA, J.M.; TORT L.; IZQUIERDO M. S. Alteration of liver and muscle fatty acid composition in gilthead sea bream (Sparus aurata) juveniles held at high stocking density and fed an essential fatty acid deficient diet. Fish Physiology and Biochemistry, v. 24, p. 63-72. 2001.

MOON, H. Y.; GATLIN, D. M. Total sulfur amino acid requirement of juvenile red drum, Sciaenops ocellatus. Aquaculture, v. 95, p. 97-106. 1991.

MOURENTE, G.; GOOD, J. E.; BELL, J. G. Partial substitution of fish oil with rapeseed, linseed and olive oils in diets for European sea bass (Dicentrarchus labrax L.): effects on flesh fatty acid composition, plasma prostaglandins E2 and F2 $\alpha$, immune function and effectiveness of a fish oil finishing diet. Aquaculture Nutrition, v. 11, n. 1, p. 25-40. 2005.

MPA / IBGE (Ministério da Pesca e Aquicultura / Instituto Brasileiro de Geografia e Estatística). Available at http://www.ibge.gov.br. 2015.

MURILlO-GURREA, D. P.; COLOSO, R. M.; BORLONGAN, I. G.; SERRANO, A. E. Lysine and arginine requirements of juvenile Asian sea bass Lates calcarifer. Journal of Applied Ichthyology, v. 17(2), p. 49-53. 2001.

NETO, H. B.; GRANER, C. A. F.; PEZZATO, L. E.; PADOVANI, C. R. Determinação de rotina do crômio em fezes, como marcador biológico, pelo método espectrofotométrico ajustado da 1, 5-difenilcarbazida. Ciência Rural, v. 35(3), p. 691-697. 2005.

NG, W.K.; HUNG, S. S. O. Estimating the ideal dietary indispensable amino acid pattern for growth of white sturgeon, Acipenser transmontanus (Richardson). Aquaculture Nutrition v. 1, p. 85-94. 1995.

NGUYEN, H. Q.; LE, T. L.; TRAN, M. T.; SORGELOOS, P.; DIERCKENS, K.; REINERTSEN, H.; SVENNEVIG, N. Cobia Rachycentron canadum aquaculture in Vietnam: recent developments and prospects. Aquaculture, v. 315(1), p. 20-25. 2011.

NOSE, T. Summary report on the requirements of essential amino acids for carp. In: Tiews, K., Halvcr, J.E. (Eds.), Finfish Nutrition and Fish Feed Technology. Heenemann GmbH, Berlin, pp. 145-156. 1979.

NUNES, A. J. P.; MADRID, R. M. M. Desmistificando a piscicultura marinha: A experiência do Vietnã. Panorama da Aquicultura, v. 24, p. 14-23. 2013.

OGATA, H.; ARAI, S.; NOSE, T. Growth responses of cherry salmon, Oncorhynchus masou, and amago salmon, 0. rhodurus, fry fed purified casein diets supplemented with amino acids. Bulletin of the Japanese Society of Scientific Fisheries, v. 49; p. 1381-1385. 1983.

OGINO, C. Requirements of carp and rainbow trout for essential amino acids. Bulletin of the Japanese Society of Scientific Fisheries, v. 46, p. 171-174. 1980. 
OSTROWSKI, A. C.; DIVAKARAN, S. The amino acid and fatty acid composition of selected tissues of the dolphin fish (Coryphaena hippurus) and their nutritional implications. Aquaculture, v. 80, p. 285-299. 1989

OTWELL, W. S; RICKARDS, W. L. Cultured and wild American eels, Anguilla rostrata: fat content and fatty acid composition. Aquaculture, v. 26, n. 1, p. 67-76. 1981.

PARK, G. S.; TAKEUCHI, T.; SEIKAI, T.; YOKOYAMA, M. The effects of dietary taurine on growth and taurine levels in whole body of juvenile Japanese flounder Paralichthys olivaceus. Nippon Suisan Gakkaishi, v. 67, p. 238-243. 2001.

PARK, G.; TAKEUCHI, T., YOKOYAMA, M., SEIKAI, T. Optimal dietary taurine level for growth of juvenile Japanese flounder Paralichthys olivaceous. Fisheries Science, v. 68, p. 824-829. 2002.

PERES, H., OLIVA-TELES, A. Effect of dietary lipid level on growth performance and feed utilization by European seabass juveniles Dicentrarchus labrax. Aquaculture, v. 179, p. 325-334. 1999.

PORTZ, L.; CYRINO, J. E. P. Comparison of the amino acid contents of roe, whole body and muscle tissue and their $\mathrm{A} / \mathrm{E}$ ratios for largemouth bass Micropterus salmoides (Lacepéde, 1802). Aquaculture Research, v. 34(8), p. 585-592. 2003.

PORTZ, L.; DIAS, C. D. S.; CYRINO, J. E. P. Regressão segmentada como modelo na determinação de exigências nutricionais de peixes. Scientia Agricola, v. 57(4), p. 601607. 2000 .

POSTON, H. A.; RUMSEY, G. L. Factors affecting dietary requirement and deficiency signs of L-tryptophan in rainbow trout. The Journal of nutrition, v. 113, n. 12, p. 2568-2577. 1983.

REN, M.; AI, Q.; MAI, K. Dietary arginine requirement of juvenile cobia (Rachycentron canadum). Aquaculture Research, v. 45(2), p. 225-233. 2014.

RESLEY, M. J.; WEBB, K. A.; HOLT, G. J. Growth and survival of juvenile cobia, Rachycentron canadum, at different salinities in a recirculating aquaculture system. Aquaculture, v. 253(1), p. 398-407. 2006.

ROBAINA, L.; IZQUIERDO, M. S.; MOYANO, F. J.; SOCORRO, J.; VERGARA, J. M.; MONTERO, D. Increase of the dietary $n-3 / n-6$ fatty acid ratio and addition of phosphorus improves liver histological alterations induced by feeding diets containing soybean meal to gilthead seabream, Sparus aurata. Aquaculture, v. 161(1), p. 281-293. 1998.

ROBERTS, R. J.; BULLOCK, A. M. Nutritional pathology. Fish nutrition, p. 453-504. 2002. 
RODEHUTSCORD, M.; BECKER, A.; PACK, M.; PFEFFER, E. Response of rainbow trout (Oncorhynchus mykiss) to supplements of individual essential amino acids in a semipurified diet, including an estimate of the maintenance requirement for essential amino acids. The Journal of nutrition, v. 127(6), p. 1166-1175. 1997.

ROSSI, W., DAVIS, D. A. Meat and Bone Meal as an Alternative for Fish Meal in Soybean Meal-Based Diets for Florida Pompano, Trachinotus carolinus L. Journal of the World Aquaculture Society, v. 45(6), p. 613-624. 2014.

ROSSI, W., DAVIS, D. A. Replacement of fishmeal with poultry by-product meal in the diet of Florida pompano Trachinotus carolinus L. Aquaculture, v. 338, p. 160-166. 2012.

RUMSEY, G. L.; KETOLA, H. G. Amino acid supplementation of casein in diets of Atlantic salmon (Salmo salar) fry and of soybean meal for rainbow trout (Salmo gairdneri) fingerlings. Journal of the Fisheries Board of Canada, v. 32(3), p. 422-426. 1975.

RUYTER, B., MOYA-FALCÓN, C., ROSENLUND, G.; VEGUSDAL, A. Fat content and morphology of liver and intestine of Atlantic salmon (Salmo salar): effects of temperature and dietary soybean oil. Aquaculture, v. 252(2), p. 441-452. 2006.

SAADIAH, I.; ABOL-MUNAFI, A. M.; UTAMA, C. C. Replacement of fishmeal in cobia (Rachycentron canadum) diets using poultry by-product meal. Aquaculture International, v. 19(4), p. 637-648. 2011.

SALZE, G. P.; DAVIS, D. A. Taurine: a critical nutrient for future fish feeds. Aquaculture, v. 437, p. 215-229. 2015.

SALZE G.; MCLEAN E.; SCHWARZ M.H.; CRAIG S.R. Dietary mannan-oligosaccharide enhances salinity tolerance and gut development of larval cobia. Aquaculture, v. 274, p. 148-152. 2008.

SALZE, G.; MCLEAN, E.; CRAIG, S. R. Dietary taurine enhances growth and digestive enzyme activities in larval cobia. Aquaculture, v. 362, p. 44-49. 2012.

SHIAU, S. Y.; CHOU, B. S. Grass shrimp, Penaeus monodon, growth as influenced by dietary taurine supplementation. Comparative biochemistry and physiology, v. 108A, p. 137-142. 1994.

SHIMADA, M. T., CLAUDIANO, G. S., ENGRACIA FILHO J. R.; YUNIS J.; MORAES, F.R. Hepatic Steatosis in Cage-Reared Young Cobia, Rachycentron canadum (Linnaeus, 1766), in Brazil. Journal of Veterinary Science and Medical Diagnosis, v. 3, p. 2.2014.

SMITH, J. W. Life history of cobia, Rachycentron canadum (Osteichthyes: Rachycentridae), in North Carolina waters. Brimleyana, v. 23, p. 1-23. 1995,

SMITH, L. S. Digestive functions in teleost fishes. In: Fish Nutrition Second Edition (J. E. 
Halver, Ed.). Academic Press, NY. pp. 331-421. 1989.

SPIES, J. R. Determination of tryptophan in proteins. Analytical Chemistry, v. 39(12), p. 14121416. 1967.

SPISNI, E., TUGNOLI, M.; PONTICELLI, A.; MORDENTI, T.; TOMASI, V. Hepatic steatosis in artificially fed marine teleosts. Journal of Fish Diseases, v. 21, p. 177-184. 1998.

STOREBAKKEN, T.; SHEARER, K. D.; BAEVERFJORD, G.; NIELSEN, B. G.; ÅSGÅRD, T.; SCOTT, T.; DE LAPORTE, A. Digestibility of macronutrients, energy and amino acids, absorption of elements and absence of intestinal enteritis in Atlantic salmon, Salmo salar, fed diets with wheat gluten. Aquaculture, v. 184(1), p. 115-132. 2000.

STURMAN, J. A. Taurine in development. Journal of Nutrition, v. 118, p. 1169-1176. 1988.

SUN, L.; CHEN, H.; HUANG, L.; WANG, Z. Growth, faecal production, nitrogenous excretion and energy budget of juvenile cobia (Rachycentron canadum) relative to feed type and ration level. Aquaculture, v. 259(1), p. 211-221. 2006a.

SUN, L.; CHEN, H.; HUANG, L.; WANG, Z.; YAN, Y. Growth and energy budget of juvenile cobia (Rachycentron canadum) relative to ration. Aquaculture, v. 257, p. 214-220. 2006 b.

SUN, LIHUA; CHEN, HAORU. Effects of ration and temperature on growth, fecal production, nitrogenous excretion and energy budget of juvenile cobia (Rachycentron canadum). Aquaculture, v. 292, n. 3, p. 197-206. 2009.

SUN, LIHUA; CHEN, HAORU. Effects of water temperature and fish size on growth and bioenergetics of cobia (Rachycentron canadum). Aquaculture, v. 426, p. 172-180. 2014.

TACON, A. G. J. The nutrition and feeding of farmed fish and shrimp; a training manual. 1: The essential nutrients. Food and Agriculture Organization of the United Nations, GCP/RLA/075/ITA, Brazil, 117 pp. 1987.

TACON, A. G. J. Feeding tomorrow's fish: keys for sustainability. Feeding Tomorrow's Fish (A. G. J. Tacon and B. Basurco, editors). Cahiers Options Mediterraneennes, v. 22, p. 1133. 1997.

TACON, A. G. J. Lipid nutritional pathology in farmed fish. Archives of Animal Nutrition, v. 49, p. 33-39. 1996.

TAKAGI, S., MURATA, H., GOTO, T., ENDO, M., YAMASHITA, H., UKAWA, M. Taurine is an essential nutrient for yellowtail Seriola quinqueradiata fed non-fish meal diets based on soy protein concentrate. Aquaculture, v. 280(1), p. 198-205. 2008. 
TESHIMA, S.; ALAM, M. S.; KOSHIO, S.; ISHIKAWA, M.; KANAZAWA, A. Assessment of requirement values for essential amino acids in the prawn, Marsupenaeus japonicus (Bate). Aquaculture Research, v. 33(6), p. 395-402. 2002.

TURNER, J. P.; ROOKER, J.R. Effect of dietary fatty acids on the body tissues of larval and juvenile cobia and their prey. Journal of Experimental Marine Biology and Ecology, v. 322, p. 13-27. 2005.

TWIBELL, R. G.; BROWN, P. B. Dietary arginine requirement of juvenile yellow perch. The Journal of nutrition, v. 127, n. 9, p. 1838-1841. 1997.

TWIBELL, R. G.; GRIFFIN M. E.; MARTIN, J.; PRICE, J.; BROWN; P. B. 2003. Predicting dietary essential amino acid requirements for hybrid striped bass. Aquaculture Nutrition, v. 9, p. 373-381.

TWIBELL, R. G.; GRIFFIN, M. E.; MARTIN, B.; PRICE, J.; BROWN, P. B. Predicting dietary essential amino acid requirements for hybrid striped bass. Aquaculture Nutrition, v. 9(6), p. 373-381. 2003.

VEGUSDAL, A.; GJØEN, T.; BERGE, R. K.; THOMASSEN, M. S.; RUYTER, B. Effect of 18: $1 \mathrm{n}-9,20: 5 \mathrm{n}-3$, and 22: $6 \mathrm{n}-3$ on lipid accumulation and secretion by Atlantic salmon hepatocytes. Lipids, v. 40(5), p. 477-486. 2005.

WALTON, M. J.; COWEY, C. B.; ADRON, J. W. The effect of dietary lysine levels on growth and metabolism of rainbow trout (Salmo gairdneri). British Journal of Nutrition, v. 52, n. 01, p. 115-122. 1984.

WALTON, M. J.; COWEY, C. B.; COLOSO, R. M.; ADRON, J. W. Dietary requirements of rainbow trout for tryptophan, lysine and arginine determined by growth and biochemical measurements. Fish Physiology and Biochemistry, v. 2(1-4), p. 161-169. 1986.

WANG, J. T.; LIU, Y. J.; TIAN, L. X.; MAI, K. S.; DU, Z.Y.; WANG, Y.; YANG, H. J. Effect of dietary lipid level on growth performance, lipid deposition, hepatic lipogenesis in juvenile cobia. Aquaculture, v. 249, p. 439-447. 2005.

WASSEF, E. A.; WAHBY, O. M.; SAKR, E. M. Effect of dietary vegetable oils on health and liver histology of gilthead seabream (Sparus aurata) growers. Aquaculture Research, v. 38 , n. 8, p. 852-861. 2007.

WATSON, A. M.; BARROWS, F. T.; PLACE, A. R. Effects of graded taurine levels on juvenile cobia. North American Journal of Aquaculture, v. 76(3), p. 190-200. 2014.

WATSON, A. M.; BUENTELlO, A.; PLACE, A. R. Partial replacement of fishmeal, poultry by-product meal and soy protein concentrate with two non-genetically modified soybean cultivars in diets for juvenile cobia, Rachycentron canadum. Aquaculture, v. 434, p. 129136. 2014. 
WHITE, J. A.; HART, R. J.; FRY, J. C. An evaluation of the Waters Pico-Tag system for the amino-acid analysis of food materials. Journal of Analytical Methods in Chemistry, v. 8, n. 4, p. 170-177. 1986.

WILSON, R. P. Amino acid nutrition of fish: a new method of estimating requirement values. In: Proceedings of 20th US-Japanese Symposium on Aquaculture Nutrition, pp. 49-89. Newport, Oregon. 28-30 October. 1991.

WILSON, R. P. Amino acids and proteins. In: Fish Nutrition (ed. by J. Halver \& R. Hardy), pp. 143-179. Academic Press, San Diego, CA, USA. 2002.

WILSON, R. P. Utilization of dietary carbohydrate by fish. Aquaculture, v. 124, n. 1, p. 67-80. 1994.

WILSON, R. P.; COWEY, C. B. Amino acid composition of whole body tissue of rainbow trout and Atlantic salmon. Aquaculture, v. 48, n. 3-4, p. 373-376. 1985.

WILSON, R. P.; POE, W. E. Relationship of whole body and egg essential amino acid patterns in channel catfish, Ictalurus punctatus. Comparative Biochemistry and Physiology, v. 80B, p. 385-389. 1985.

ZHAO, H. X.; CAO, J. M.; WU, J. K.; TAN, Y. G.; ZHOU, M.; LIANG, H. O.; YANG, D. W. Studies of arginine requirement for juvenile cobia. Journal of South China Agricultural University, v. 28(4), p. 87-90. 2007.

ZHOU, Q. C.; MAI, K. S., TAN, B. P.; LIUY, J. Partial replacement of fishmeal by soybean meal in diets for juvenile cobia (Rachycentron canadum). Aquaculture Nutrition, v. 11, p. 175-182. 2005.

ZHOU, Q. C.; TAN, B. P.; MAI, K. S.; LIU Y. H. Apparent digestibility of selected feed ingredients for juvenile cobia Rachycentron canadum. Aquaculture, v. 241, p. 441-451. 2004.

ZHOU, Q. C.; WU, Z. H.; CHI, S. Y.; YANG, Q. H. Dietary lysine requirement of juvenile cobia (Rachycentron canadum). Aquaculture, v. 273, p. 634-640. 2007.

ZHOU, Q. C.; WU, Z. H.; TAN, B. P.; CHI, S. Y.; YANG, Q. H. Optimal dietary methionine requirement for juvenile cobia (Rachycentron canadum). Aquaculture, v. 258(1), p. 551557. 2006. 
CHAPTER 4

Dietary methionine requirement of juvenile Florida pompano Trachinotus carolinus. 


\section{Preface}

This chapter contains the result of my internship research (April to September of 2015) undertaken at the Experimental Hatchery of the University of Miami, Rosenstiel School of Marine and Atmospheric Science, USA. The internship was funded by The Brazilian National Council for the Development of Science and Technology (CNPq), as part of the activities of the AquaMar Research Project "Feeding Tomorrow's Fish: Environmental and Sustainable Aquaculture Feeds and Feeding Regimes for Marine Farming”.

The research was conducted under the supervision of the Professor Dr. Daniel Benetti and Dr. Jorge Suarez, as part of the research project concerning the "Use of Soy-based Products in Practical Diets for Florida Pompano, Trachinotus carolinus. Phase III", funded by United Soybean Board of the United States of America. The proposed goal of the project was to quantify the total sulfur amino acid requirement of adult Florida Pompano, Trachinotus carolinus and determine the replacement value of cysteine for methionine, in order to optimize the soybean-based product in aquaculture feeds. Furthermore, the experimental feed design and production of diets were carried out with the collaboration of Dr. Delbert M. Gatlin (Texas A\&M University, USA) and Dr. Frederic T. Barrow (Fish Technology Center, USDA-Idaho, USA). 


\begin{abstract}
Florida pompano Trachinotus carolinus is a truly euryhaline species of high market value and demand. The objective of this study was to quantify the total sulfur amino acid requirement of juvenile Florida Pompano, using combinations of various soybean protein products in order to develop cost-effective and environmentally-friendly diets. A feeding trial was conducted to determine the dietary methionine requirement of juvenile Florida pompano (initial body weight $55 \mathrm{~g}$ ). Six diets were formulated with six graded levels of methionine (D-1: 0.50\%, D-2: 0.70\%, D-3: $0.90 \%$, D-4: $1.10 \%$, D-5: $1.30 \%$, and D-6: $1.50 \%$ of dry diet). The basal diet (D-1) was formulated to contain $43 \%$ crude protein, with half $(21.5 \%)$ of the dietary protein being supplied by fish-meal, wheat gluten, soybean meal, and soy protein concentrate. The remaining $21.5 \%$ of the dietary protein was provided in the from a L-crystalline amino acid premix. Each diet was randomly assigned to triplicate groups of 20 juvenile fish in an open-flow tank water system. Fish were fed twice daily to apparent satiation for 45 days. Significant fish performance results were observed among the treatments. Significant difference in weight gain (from 153.6 to 202.5\%), and specific growth rate (from 2.06 to 2.45\%) were observed in fish fed the basal diet (D-1) and diet D-6, respectively. Relative high coefficients of variation among the three tanks of the same treatment was found for both D-1 and D-6 (12\% and 16\%, respectively). PER was significant lower for the basal diet (D-1), compared with the D-5 and D-6. Overall, the diet supplemented with the higher level of L-methionine showed the best performance results. No significant differences were observed within the FCRs among the treatments. All tanks displayed good survival over the 45 days feeding period, ranging from 95.0 to $100.0 \%$. Based on weight gain, the dietary methionine requirement suggested from the broken-line regression analysis was $1.08 \mathrm{~g} / \mathrm{kg}$ of methionine, $\mathrm{R}^{2}=0.30$, however the low $\mathrm{R}$-square and high variation among the three replicates per diet does not provide sufficiency robustness for its estimation. In conclusion, there was an apparent tendency in the results, but the range of methionine levels employed in this study may not have been broad enough to accurately measure the dietary concentration necessary to estimate the total sulfur amino acid requirement of Florida pompano. In addition, high variation results among the three replicates per diet did not provide sufficiency robustness for its estimation.
\end{abstract}




\subsection{Introduction}

Selecting a new fish species for aquaculture has essential importance for the future development of this industry. In the United States, Florida pompano, Trachinotus carolinus, is among the marine fish species with aquaculture potential that has caught the interest of the industry for being a truly euryhaline species of high market value and demand. This species can be raised in marine or low-salinity environments, tolerates low dissolved oxygen and handling stress, accepts balanced feeds, and can be reproduced in captivity (RICHE, 2009; RICHE; WILLIAMS, 2010). The technology for raising this species from egg to market has been developed at the University of Miami Experimental Hatchery. However, some specific scientific and technological hurdles related to feeds must be tackled and resolved before Florida pompano aquaculture can expand to industrial scale.

Today, private operations are beginning to produce Florida pompano in cages and intensive recirculating systems targeting the production of marketable sized fish year-round. The increasing interest for commercial production in the United States is driven by the strong consumer demand that consistently exceeds supply and by attractive prices. The prices of pompano filets can range from US\$ 35 to US\$ $45 / \mathrm{kg}$, depending on the time of the year and availability (WEIRICH, 2011), making pompano aquaculture economically attractive. However, commercial formulated feeds for this species need to be optimized for production in order to run a profitable aquaculture operation. Generally, fish-meal is incorporated in feeds for marine fishes at levels ranging from 30 to $60 \%$ (WANG et al., 2006). Research efforts have consistently reduced the levels of fish-meal used in aquatic feeds with the inclusion of plant based ingredients such as soybean meal. However, relative low levels of methionine and lysine, the presence of anti-nutritional factors, and palatability problems may limit high inclusion levels of soybean in diets of aquatic animals (GATLIN et al., 2007). The utilization of high levels of soy-based products to replace fish-meal has resulted in depressed growth of pompano (DAVIS et al., 2009; LAZO et al., 1998; RICHE; WILLIAMS, 2011). Therefore, the evaluation of other potential alternative ingredients for fishmeal is necessary. These include specific studies to determine the total sulfur amino acid requirement and cysteine replacement value for methionine.

Methionine and cysteine are classified as sulfur-containing amino acids. Adequate 
amounts of both methionine and cysteine are needed for proper protein synthesis and other physiological functions of the fish. Methionine is one of the first limiting essential amino acids (EAAs) in many fish diets, especially those containing higher levels of plant protein sources such as soybean meal, peanut meal and copra meal (GOFF; GATLIN, 2004). Methionine deficiency results in slow growth, reduced feed efficiency and the development of lanticular cataracts in certain fish species (WALTON et al., 1982; KEEMBIYEHETTY; GATLIN, 1993). Cysteine is considered dispensable because it can be synthesized by the fish from the indispensable amino acid methionine. As cysteine can only be synthesized from a methionine precursor, a portion of the methionine requirement can be spared by cysteine in some fish species (MOON; GATLIN, 1991; KIM et al., 1992; GOFF; GATLIN, 2004). So, it is important to consider the dietary cysteine concentration to quantify the total sulfur amino acid requirement of the cultured species for maximum growth and efficient feed utilization (LUO et al., 2005). If cysteine is included in the diet, it reduces the amount of dietary methionine needed. Thus, to determine the total sulfur amino acid requirement (methionine plus cysteine), the dietary requirement for methionine is determined either in the absence of cysteine or with test diets containing very low levels of cysteine (NRC, 2011). Supplementing soybean meal with commercially available methionine has been shown to improve growth response of many fish species (VIOLA et al., 1982; CAI; BURTLE, 1996). For the supplementation of methionine in fish feeds containing methioninedeficient plant protein sources, accurate information on methionine requirement of fish is essential. In addition, it is known as a precursor of choline and various other metabolic processes (RUCHIMAT et al., 1997; KASPER et al., 2000).

The requirements for digestible protein, and the optimal digestible protein to digestible energy ratio for Florida pompano have been established (RICHE, 2009). However, the requirements for individual amino acids remain unknown. Quantifying these EAA requirements would allow for more precise formulations that result in reduced dietary protein levels, increased nitrogen retention, and cost savings (FURUYA et al., 2004). Dose-response experiments utilizing graded levels of the EAA of interest are often used to estimate the requirement. This approach utilizes a semi-purified or other basal diet with a modest level of one or more intact proteins and supplemented with additional amino acid to match the profile of a high quality reference protein (COWEY, 1995; NRC, 2011). A minimum dietary requirement is then 
estimated based on a given response factor, typically growth or nitrogen retention. Dose response experiments where the physiological variable measured is live weight gain are the most useful means for investigating amino acid requirements of fish (NRC, 2011) and many EAA requirements have been determined with this method. Growth responses such as weight gain have been used extensively by nutritionists because of the easy of taking these measurements and the applicability of the results to fish farmers. When graded levels of a nutrient are fed to replicate groups of fish, the experiment should be of sufficient duration to show a recognizable dose response relationship, with clear differences apparent between treatments (COWEY, 1995). Once a clear relationship between the growth of the fish and the dietary level of a nutrient is apparent, a variety of statistical regression techniques can be applied to the data to determine the requirement value. The use of several fish per tank, with replicate tanks, allows for variations in the responses of individual fish and avoids the confounding of treatment and tank effects. To ensure that the results of a growth study are applicable in practical situations, it is recommended that the rate of growth achieved be comparable to that when the species receives a high quality practical diet. This way, the measured requirement is representative of the amount required for protein accretion and not maintenance of body proteins. The weight gain (\%) and specific growth rate (SGR) are the most commonly used methods to express the growth rate of fish (NRC, 2011).

Many investigators have reported the quantitative methionine requirements of commonly cultured fish species with a range from 0.4 to $1.5 \%$ of the dry diet (NRC, 2011). More recently, NIU et al. (2013) reported the requirements of methionine in golden pompano, Trachinotus ovatus $(1.06 \%$ of the diet). The results of this study are very valuable but the study was performed on another species of pompano and also with small fish (initial body weight: $12.5 \mathrm{~g}$ Final body weight $72.0 \mathrm{~g}$ ). Innovative scientific research is needed to complete our knowledge of the nutritional requirements of Florida Pompano at different ages, in order to develop costeffective and environmentally-friendly diets. Particularly for larger sizes, very little research has been conducted to determine nutritional requirements and development of practical diets for this species. The requirement for total sulfur amino acids can be met by either methionine alone or the proper mixture of methionine and cysteine (MOON; GATLIN, 1991). The objective of this study is to quantify the methionine requirement for adult Florida Pompano, Trachinotus carolinus in large fish, which consume higher amounts of food. 


\subsection{Materials and Methods}

Experimental animals

Juvenile pompano (15g mean weight) were obtained from Harbor Branch Oceanographic Institute, Fort Pierce, FL, USA. Fish were loaded into a hauling tank equipped with a supplemental oxygen supply system and transported to the University of Miami Experimental Hatchery. Fish were then acclimated by slowly replacing the hauling water and subsequently stocked into a 12,000 L open flow system fiberglass tank equipped with supplemental aeration provided by a regenerative air blower and air diffusers (Figure 1). During this period fish were fed to apparent satiation with a $40 \%$ crude protein and $12 \%$ crude fat commercial marine fish extruded diet (EXTR 400, Rangen Inc., Map Angleton, TX). The water quality parameters (salinity, $\mathrm{pH}$, dissolved oxygen and temperature) were monitored daily (at about 08:00 hours), using a YSI $85^{\circledR}$ Meter (YSI Inc., Yellow Springs, USA). Fish remained in this tank for approximately 60 days acclimating to local conditions until reaching an adequate size (55 g initial body weight) for the growth trial.

\section{Experimental culture conditions}

The feeding trial was conducted at the University of Miami Experimental Hatchery (UMEH), Miami, FL, USA, in a flow-through tank water system (Figure 1). The system comprised of eighteen polyethylene plastic tanks $(1,000 \mathrm{~L}, 1.0 \mathrm{~m}$ of diameter with a conical bottom), with a nominal flow rate of $4 \mathrm{~L} / \mathrm{min}$. Well water was pumped with a $2.0 \mathrm{hp}$ centrifugal pump (Hayward Industries Inc., Elizabeth, NJ, USA) and mechanically filtrated with a sand filtered housing filled with crushed coral media (Triton II, Pentair Pool Ltd., Minneapolis, MN, USA). Supplemental aeration was provided to each tank to maintain dissolved oxygen levels near saturation, with each tank containing one air stone and an oxygen stone. Tanks were covered by a shading lid with natural illumination, approximating $12 \mathrm{~h}$ light and $12 \mathrm{~h}$ dark (Figure 1). 


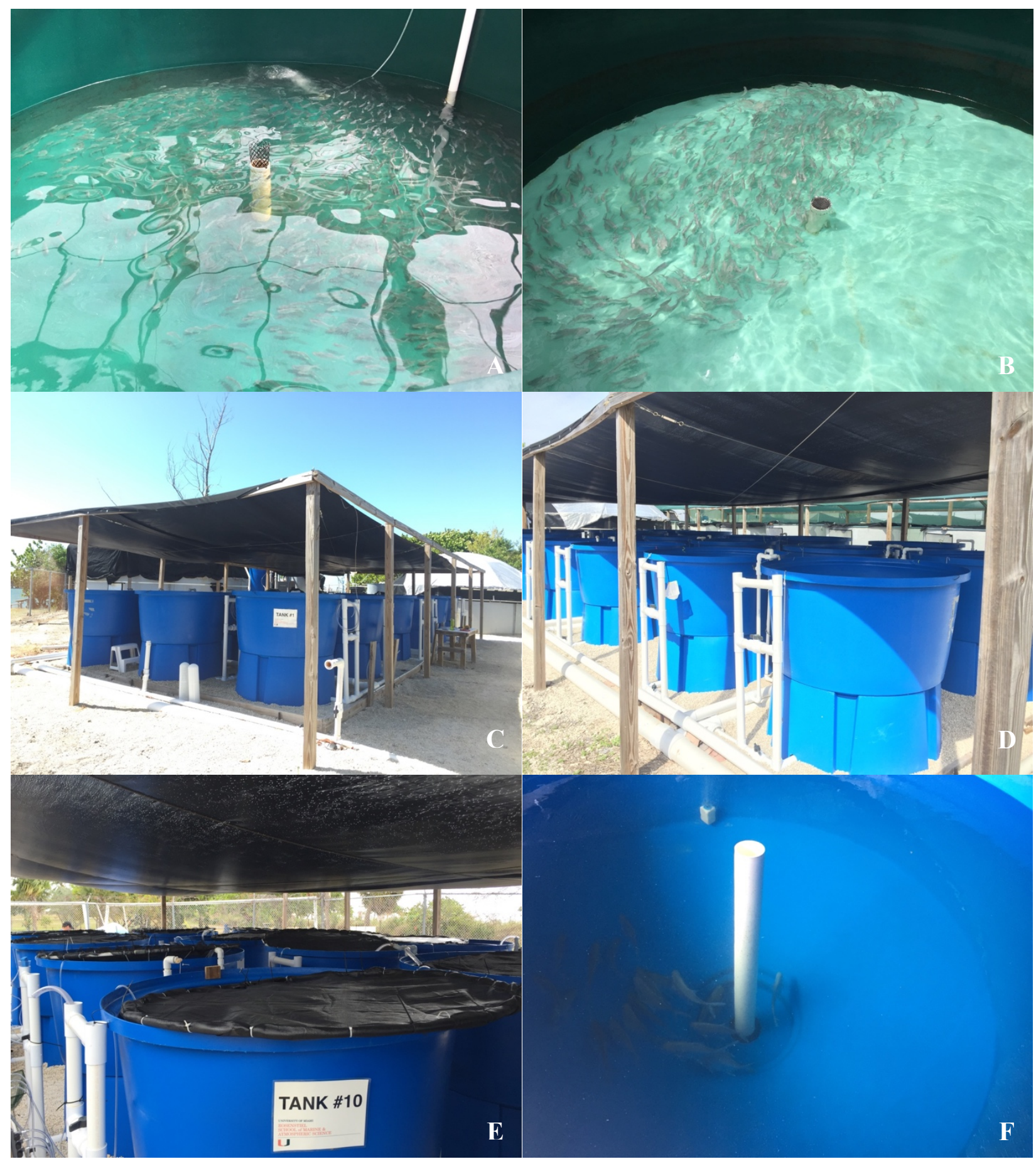

Figure 1 Florida pompano Trachinotus carolinus juveniles stocked into a 12,000 L open flow system fiberglass tank $(\boldsymbol{A} ; \boldsymbol{B})$. Overview of the University of Miami Experimental Hatchery $(\boldsymbol{C})$, comprised of eighteen polyethylene plastic tanks $(\boldsymbol{D})$. Tanks were covered by a shading lid with natural illumination $(\boldsymbol{E})$. View from inside the tank of $1.0 \mathrm{~m}$ of diameter with a conical bottom $(\boldsymbol{F})$. 


\section{Ingredients}

Fish-meal, wheat gluten, soybean meal, and soy protein concentrate (SPC) were used in the diets manufacturing in order to provide $21.5 \%$ of crude protein. Amino acid and proximate compositions of these ingredients were determined by Eurofins Scientific Inc., Nutrition Analysis Center using standard AOAC methods (Table 1).

\section{Experimental diets}

Six iso-nitrogenous and iso-energetic diets were formulated with six graded levels of methionine: D-1: $0.50 \%$, D-2: 0.70\%, D-3: 0.90\%, D-4: 1.10\%, D-5: 1.30\%, and D-6: 1.50\% (Table 2). The basal diet (D-1) was formulated to contain $43 \%$ crude protein, with half $(21.5 \%)$ of the dietary protein being provided by fish-meal, wheat gluten, soybean meal, and soy protein concentrate (SPC). The remaining $21.5 \%$ of the crude protein was sourced from an L-crystalline amino acid premix containing the amino acids listed in Table 3, with the addition of taurine and excluding methionine and cysteine. In order to supplement the diets with the appropriate quantities of the various crystalline amino acids, the amino acid composition of the Florida pompano Trachinotus carolinus tissue was used as a reference. Five fish from UMEH were randomly selected, frozen, grinded, and homogenized before being lyophilized. The lyophilized Florida pompano tissue was then sent to Texas A\&M University Aquacultural Research and Teaching Facility for amino acid composition analyses. The basal diet simulate the amino acid pattern found in 43\% crude protein from Florida Pompano Trachinotus carolinus muscle except for cysteine and methionine (Table 4).

Incremental levels of L-methionine were added to the basal diet to quantify the methionine requirement. These levels ranged such that the lowest and highest levels were well below and above the anticipated requirement, based on values for Trachinotus ovatus (NIU et al., 2013). The dietary methionine levels starting with the lowest L-methionine percent were 0.00, $0.21,0.40,0.61,0.81$, and $1.02 \%$. The diets were made iso-nitrogenous by adjusting the levels of aspartic acid and glutamic acid (at a ratio of 1:1) as the level of L-methionine is increased. The amount of nitrogen in these amino acids were quantified to determine the proper adjustments required for each diet. Formulated methionine levels were confirmed by analysis (Table 5). 
Table 1 - Proximate and amino acid composition of the main ingredients used in the manufactures of the six experimental diets to juvenile Florida pompano Trachinotus carolinus fed for 45 days (\%, as fed basis).

\begin{tabular}{|c|c|c|c|c|}
\hline Proximate composition & Fish meal $^{1}$ & Soybean meal $^{2}$ & $\begin{array}{l}\text { Soy protein } \\
\text { concentrate }\end{array}$ & Wheat flour ${ }^{2}$ \\
\hline Moisture & 6.62 & 9.31 & 6.94 & 12.10 \\
\hline Crude protein & 79.58 & 48.23 & 66.42 & 11.19 \\
\hline Crude fat & 10.01 & 3.41 & 1.00 & 1.76 \\
\hline Crude fiber & $<0.2$ & 3.50 & 3.80 & 0.20 \\
\hline Ash & 4.06 & 6.70 & 5.46 & 0.61 \\
\hline $\mathrm{NFE}^{3}$ & - & 28.84 & 16.38 & 74.14 \\
\hline Energy $(\mathrm{kJ} / \mathrm{g})$ & 23.15 & 18.17 & 19.19 & 16.23 \\
\hline \multicolumn{5}{|l|}{ Essential amino acids } \\
\hline Arginine & 4.83 & 3.25 & 4.62 & 0.41 \\
\hline Histidine & 1.87 & 1.24 & 1.74 & 0.23 \\
\hline Isoleucine & 3.88 & 2.23 & 3.07 & 0.38 \\
\hline Leucine & 7.36 & 3.69 & 5.23 & 0.73 \\
\hline Lysine & 6.98 & 3.13 & 4.40 & 0.28 \\
\hline Methionine & 2.53 & 0.71 & 0.96 & 0.17 \\
\hline Phenylalanine & 3.71 & 2.44 & 3.40 & 0.54 \\
\hline Threonine & 4.08 & 2.12 & 2.98 & 0.38 \\
\hline Tryptophan & 1.01 & 0.70 & 0.97 & 0.13 \\
\hline Valine & 4.45 & 2.31 & 3.17 & 0.47 \\
\hline Taurine & 0.20 & 0.02 & $<0.01$ & $<0.01$ \\
\hline \multicolumn{5}{|c|}{ Non-essential amino acids } \\
\hline Cysteine & 0.94 & 0.69 & 0.90 & 0.24 \\
\hline Tyrosine & 3.10 & 1.59 & 2.17 & 0.30 \\
\hline Serine & 4.00 & 2.69 & 3.77 & 0.59 \\
\hline Aspartic Acid & 7.97 & 5.44 & 7.63 & 0.49 \\
\hline Glutamic Acid & 12.51 & 8.74 & 12.49 & 3.58 \\
\hline Proline & 3.62 & 2.50 & 3.54 & 1.22 \\
\hline Alanine & 4.93 & 2.08 & 2.90 & 0.34 \\
\hline
\end{tabular}

${ }^{1}$ SeaPro 75 - BioOregon Protein, Inc., Warrenton, OR, USA.

${ }^{2}$ Sourced by Fish Technology Center (Bozeman, MT, USA).

${ }^{3}$ Nitrogen-free extract calculated by difference: 100 - moisture - crude protein - ash - crude fat fiber.

Dash indicates not determined or zero if not present. 
Table 2 - Formulation and proximate composition of diets fed to juvenile Florida pompano Trachinotus carolinus for 45 days.

\begin{tabular}{|c|c|c|c|c|c|c|}
\hline \multirow{2}{*}{ Ingredient (\%) } & \multicolumn{6}{|c|}{ Diet } \\
\hline & D-1 & D-2 & D-3 & D-4 & D-5 & D-6 \\
\hline Fish meal SeaPro $75^{1}$ & 12.50 & 12.50 & 12.50 & 12.50 & 12.50 & 12.50 \\
\hline Soy bean, solvent extracted ${ }^{2}$ & 7.50 & 7.50 & 7.50 & 7.50 & 7.50 & 7.50 \\
\hline SPC, Profine $\mathrm{VF}^{2}$ & 7.50 & 7.50 & 7.50 & 7.50 & 7.50 & 7.50 \\
\hline Wheat Flour ${ }^{2}$ & 12.00 & 12.00 & 12.00 & 12.00 & 12.00 & 12.00 \\
\hline Fish Oil $^{2}$ & 13.73 & 13.73 & 13.73 & 13.73 & 13.73 & 13.73 \\
\hline Choline $60 \%{ }^{2}$ & 0.23 & 0.23 & 0.23 & 0.23 & 0.23 & 0.23 \\
\hline Lecithin $^{2}$ & 1.00 & 1.00 & 1.00 & 1.00 & 1.00 & 1.00 \\
\hline Luctamold $^{2}$ & 0.25 & 0.25 & 0.25 & 0.25 & 0.25 & 0.25 \\
\hline Ethoxyquin $^{2}$ & 0.03 & 0.03 & 0.03 & 0.03 & 0.03 & 0.03 \\
\hline Vitamin/Mineral premix ${ }^{3}$ & 1.00 & 1.00 & 1.00 & 1.00 & 1.00 & 1.00 \\
\hline Celufil $^{4}$ & 25.06 & 25.06 & 25.06 & 25.06 & 25.06 & 25.06 \\
\hline Amino acid premix ${ }^{5}$ & 19.21 & 19.21 & 19.21 & 19.21 & 19.21 & 19.21 \\
\hline \multicolumn{7}{|c|}{ Proximate composition (\% as fed basis) } \\
\hline Moisture & 5.61 & 4.77 & 4.28 & 4.96 & 5.84 & 5.32 \\
\hline Crude protein & 39.72 & 40.14 & 40.97 & 39.75 & 39.18 & 38.14 \\
\hline Lipid & 15.26 & 14.97 & 14.42 & 15.05 & 14.70 & 15.10 \\
\hline Ash & 2.08 & 1.95 & 1.95 & 1.92 & 1.94 & 1.86 \\
\hline Gross energy (kcal/100g) & 5.06 & 5.13 & 5.10 & 5.14 & 5.07 & 5.11 \\
\hline
\end{tabular}


Table 3 - Composition of the amino acid premix included in the juvenile Florida pompano Trachinotus carolinus experimental diets.

\begin{tabular}{lllllll}
\hline \multirow{2}{*}{ Amino acid premix (\%) } & \multicolumn{7}{c}{ Diet } \\
\cline { 2 - 7 } & D-1 & D-2 & D-3 & D-4 & D-5 & D-6 \\
\hline Arginine $^{1}$ & 1.49 & 1.49 & 1.49 & 1.49 & 1.49 & 1.49 \\
Histidine $^{2}$ & 0.51 & 0.51 & 0.51 & 0.51 & 0.51 & 0.51 \\
Isoleucine $^{3}$ & 1.03 & 1.03 & 1.03 & 1.03 & 1.03 & 1.03 \\
Leucine $^{4}$ & 1.62 & 1.62 & 1.62 & 1.62 & 1.62 & 1.62 \\
Lysine $^{5}$ & 2.01 & 2.01 & 2.01 & 2.01 & 2.01 & 2.01 \\
Methionine $^{6}$ & $\mathbf{0 . 0 0}$ & $\mathbf{0 . 2 2}$ & $\mathbf{0 . 4 2}$ & $\mathbf{0 . 6 2}$ & $\mathbf{0 . 8 2}$ & $\mathbf{1 . 0 4}$ \\
Cysteine $^{7}$ & 0.00 & 0.00 & 0.00 & 0.00 & 0.00 & 0.00 \\
Phenylalanine $^{8}$ & 0.90 & 0.90 & 0.90 & 0.90 & 0.90 & 0.90 \\
Tyrosine $^{9}$ & 0.17 & 0.17 & 0.17 & 0.17 & 0.17 & 0.17 \\
Threonine $^{10}$ & 0.98 & 0.98 & 0.98 & 0.98 & 0.98 & 0.98 \\
Tryptophan $^{11}$ & 0.43 & 0.43 & 0.43 & 0.43 & 0.43 & 0.43 \\
Valine $^{12}$ & 1.24 & 1.24 & 1.24 & 1.24 & 1.24 & 1.24 \\
Taurine $^{13}$ & 0.46 & 0.46 & 0.46 & 0.46 & 0.46 & 0.46 \\
Serine $^{14}$ & 0.66 & 0.66 & 0.66 & 0.66 & 0.66 & 0.66 \\
Glycine $^{15}$ & 3.20 & 3.20 & 3.20 & 3.20 & 3.20 & 3.20 \\
Aspartic Acid $^{16}$ & 0.52 & 0.41 & 0.31 & 0.21 & 0.11 & 0.00 \\
Glutamic Acid $^{17}$ & 0.52 & 0.41 & 0.31 & 0.21 & 0.11 & 0.00 \\
Alanine $^{18}$ & 2.24 & 2.24 & 2.24 & 2.24 & 2.24 & 2.24 \\
Proline $^{19}$ & 1.23 & 1.23 & 1.23 & 1.23 & 1.23 & 1.23 \\
Total $^{19}$ & 19.21 & 19.21 & 19.21 & 19.21 & 19.21 & 19.21 \\
\hline
\end{tabular}

$1,2,3,4,8,9,11,12,14,15,16,17,18$ Affymetrix, Inc, Santa Clara, CA, USA.

$5,6,7,10,13,19$ Sigma-Aldrich, St. Louis, MO, USA. 
Table 4 - Florida pompano Trachinotus carolinus whole body amino acid profile used as reference in the formulation of the six experimental diets ( $\%$ dry matter).

\begin{tabular}{ll}
\hline Essential amino acids & $\%$ \\
\hline Arginine & 4.51 \\
Histidine & 1.65 \\
Isoleucine & 3.23 \\
Leucine & 5.47 \\
Lysine + tyrosine & 7.22 \\
Methionine & 2.04 \\
Phenylalanine & 3.10 \\
Threonine & 3.17 \\
Tryptophan & - \\
Valine & 3.73 \\
Taurine & 0.77 \\
Non-essential amino acids & \\
Cysteine & 0.16 \\
Glycine & 6.57 \\
Serine & 2.88 \\
Aspartic Acid & 5.76 \\
Glutamic Acid & 8.29 \\
Proline & 3.77 \\
Alanine & 5.32 \\
\hline
\end{tabular}

Data are mean values $(n=3)$.

Dash indicates not determined or zero if not present. 
Table 5 - Analyzed amino acid composition of the six experimental diets fed to juvenile Florida pompano Trachinotus carolinus (\% dry matter).

\begin{tabular}{lllllll}
\hline \multirow{2}{*}{ Amino acid } & \multicolumn{7}{c}{ Diet } \\
\cline { 2 - 7 } & $\mathrm{D}-1$ & $\mathrm{D}-2$ & $\mathrm{D}-3$ & $\mathrm{D}-4$ & $\mathrm{D}-5$ & $\mathrm{D}-6$ \\
\hline Arginine & 3.09 & 3.06 & 3.05 & 3.04 & 3.00 & 3.02 \\
Histidine & 1.04 & 1.03 & 1.04 & 1.03 & 1.00 & 1.03 \\
Isoleucine & 2.15 & 2.13 & 2.18 & 2.14 & 2.11 & 2.14 \\
Leucine & 3.62 & 3.59 & 3.61 & 3.59 & 3.55 & 3.57 \\
Lysine & 3.55 & 3.49 & 3.48 & 3.51 & 3.44 & 3.51 \\
Methionine & $\mathbf{0 . 5 2}$ & $\mathbf{0 . 7 1}$ & $\mathbf{0 . 9 2}$ & $\mathbf{1 . 1 1}$ & $\mathbf{1 . 2 9}$ & $\mathbf{1 . 5 6}$ \\
Cysteine & 0.27 & 0.27 & 0.27 & 0.27 & 0.27 & 0.28 \\
Phenylalanine & 2.03 & 2.03 & 2.03 & 2.01 & 1.99 & 2.00 \\
Tyrosine & 4.28 & 4.26 & 4.26 & 4.26 & 4.19 & 4.27 \\
Threonine & 1.93 & 1.90 & 1.90 & 1.88 & 1.87 & 1.90 \\
Tryptophan & 0.71 & 0.68 & 0.69 & 0.73 & 0.71 & 0.71 \\
Valine & 2.61 & 2.54 & 2.48 & 2.48 & 2.44 & 2.46 \\
Taurine & 0.71 & 0.70 & 0.71 & 0.71 & 0.71 & 0.72 \\
Serine & 1.53 & 1.50 & 1.50 & 1.46 & 1.45 & 1.49 \\
Glycine & 4.54 & 4.45 & 4.45 & 4.47 & 4.39 & 4.49 \\
Aspartic Acid & 2.77 & 2.62 & 2.55 & 2.46 & 2.33 & 2.28 \\
Glutamic Acid & 4.47 & 4.27 & 4.19 & 4.03 & 3.85 & 3.79 \\
Alanine & 1.16 & 1.13 & 1.16 & 1.14 & 1.12 & 1.14 \\
Proline & 2.47 & 2.41 & 2.41 & 2.40 & 2.40 & 2.38 \\
Total & 43.45 & 42.77 & 42.88 & 42.72 & 42.11 & 42.74 \\
\hline
\end{tabular}




\section{Manufacturing of experimental diets}

All diets were manufactured at the Fish Technology Center (Bozeman, MT, USA) by cooking extrusion, under the supervision of Dr. Frederick T. Barrows (Figure 2). The ingredients were ground to a particle size of $<200 \mu \mathrm{m}$ using an air-swept pulverizer (Model 18H, Jacobsen, Minneapolis, MN, USA). The diets were processed using a twin-screw cooking extruder (DNDL-44, Buhler AG, Uzwil, Switzerland) with an 8-14 second exposure to 125$145^{\circ} \mathrm{C}$ in the extruder barrel using a $5 \mathrm{~mm}$ die opening. Pressure at the die head varied from 3247 bar, depending on test ingredient. Pellets were flash dried with a $4 \mathrm{M}$ conveyor and cooling fan then collected and batch dried with a pulse bed drier (Buhler AG, Uzwil, Switzerland) for approximately 20 minutes at $98^{\circ} \mathrm{C}$ resulting in final moisture levels less than $10 \%$ followed by cooling with forced air at ambient temperature for approximately 15 minutes. All added fish oil was top-coated on the dried and cooled feed using a vacuum coater (A.J. Mixing, Ontario, Canada). Diets were stored in plastic lined paper bags at room temperature until fed.

\section{Feeding protocol}

Twenty fish (average weight of $55.0 \pm 9.9$ g) were individually weighed and randomly distributed in each of the eighteen tank, at initial density of $1.1 \mathrm{~kg} / \mathrm{m}^{3}$. Fish were weighed at the beginning and end of the experiment (45 days). The weighing process was carried out on a table next to the tank system, and the animals anaesthetized with $200 \mathrm{mg} / \mathrm{L}$ of tricaine methanesulfonate (MS-222; Western Chemical, Inc., Ferndale, WA, USA), and then individually weighed (dry) using a plastic ruler and an analytical balance (Figure 2). There were 3 replicates per each of the six dietary treatments. The fish were fed test diets to apparent satiation (without overfeeding) twice daily at 9:00 and 16:00 h. As long as fish were fed to satiation, they would never come up water surface again. Hence, their apparent satiation could be judged by feeding behavior observation. Fecal matter was siphoned off and the unconsumed feed, if any, collected soon after active feeding, dried and weighed to measure the actual amount of feed consumed (Figure 2). The duration of the feeding routine was around 1:00 hour, in order for one person to feed all the 18 tanks. Fish mortalities were recorded whenever apparent. The feeding trial lasted for 45 days. 


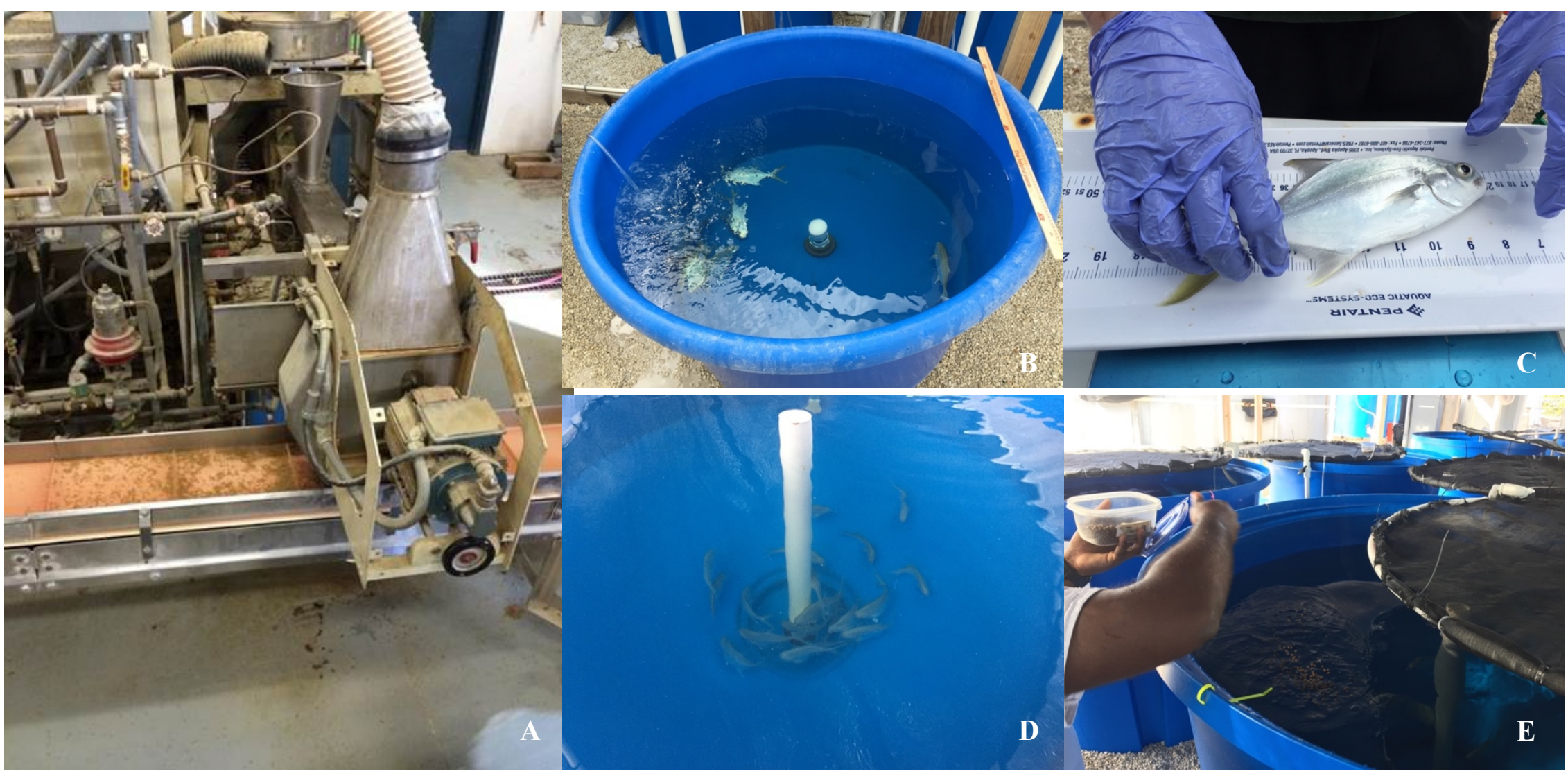

Figure 2 Manufacturing of diets at the Fish Technology Center (Bozeman, MT, USA). Photo courtesy of Dr. Rick Barrows (A). Animals were anaesthetized (B), then individually weighed using a plastic ruler and an analytical balance $(\boldsymbol{C})$. Twenty fish (average weight of $55.0 \pm 9.9 \mathrm{~g}$ ) were randomly distributed in each of the eighteen tank $(\boldsymbol{D})$. The fish were fed test diets to apparent satiation (without overfeeding) twice daily at 9:00 and 16:00 $h(\boldsymbol{E})$. 
Fish performance calculations

At the termination of the experiment (45 days), all fish from each replicate of dietary treatments were pooled separately, culled with $200 \mathrm{mg} / \mathrm{L}$ of tricaine methanesulfonate (MS-222; Western Chemical, Inc., Ferndale, WA, USA), and individually weighted. Visceral somatic index and hepatosomatic index was calculated using three fish per treatment (Figure 3). Feed and fish performance was evaluated using the following biometrics:

Initial body weight $(\mathrm{g})=$ (initial total mass of tank weight / number of fish),

Final body weight $(\mathrm{g})$ = (final total mass of tank weight / number of fish),

Weight gain $(\%)=($ final fish biomass $(\mathrm{g})-$ initial shrimp biomass $(\mathrm{g})) /$ initial fish biomass $(\mathrm{g}) * 100$,

SGR - specific growth rate $=(\ln$ final weight $-\ln$ initial weight $) /$ days $* 100$,

$\mathrm{FCR}-$ feed conversion ratio $=$ total feed offered $(\mathrm{g}$, as fed) $/($ final fish biomass $(\mathrm{g})-$ initial fish biomass (g)),

PER - protein efficiency ratio $=($ final fish biomass $(\mathrm{g})-$ initial fish biomass $(\mathrm{g})) /$ grams protein fed (dry matter basis),

Survival $(\%)=($ final number of fish / initial number of fish $) * 100$,

Visceral somatic index $(\mathrm{VSI})=($ viscera weight $/$ fish weight $) * 100$,

Hepatosomatic index $($ HIS $)=($ liver weight $/$ fish weight $) * 100$. 


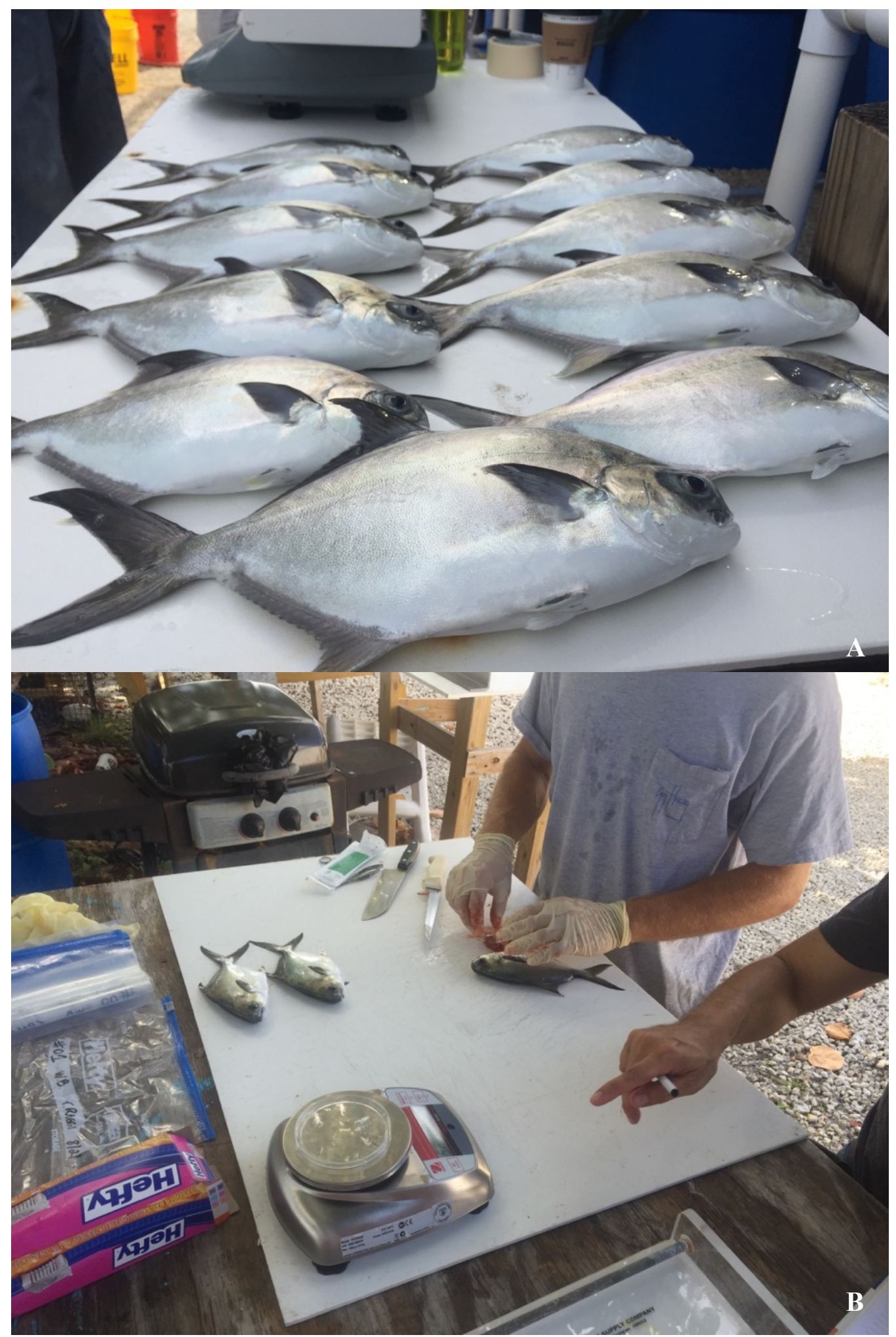

Figure 3 At the termination of the experiment, all fish from each replicate of dietary treatments were pooled separately, culled, and individually weighted (A). Visceral somatic index and hepatosomatic index was calculated using three fish per treatment (B). 


\section{Chemical analysis}

Chemical analyses were done by service providers using standard methods (AOAC, 2005). Moisture was determined by drying in an oven at $105{ }^{\circ} \mathrm{C}$ for $24 \mathrm{~h}$; protein levels were calculated from the determination of total nitrogen with a LECO auto-analyzer, and the calculations were based on N x 6.25 (AOAC, 2005). Dietary crude fat contents were determined gravimetrically following lipid extraction using the Soxhlet method, and crude ash by incineration in a muffle furnace at $550{ }^{\circ} \mathrm{C}$ for $24 \mathrm{~h}$ (AOAC, 2005). Feed energy content were measured using an adiabatic bomb calorimeter. Amino acids concentrations in the diets were analyzed via the UPLC (Acquity system; Waters Corporation) and the commercial kit MassTrak (POHLENZ et al., 2012). The MassTrak kit uses precolumn derivatization of amino acids with a 6-aminoquinolyl-N-hydroxysuccinimidyl carbamate tag (AccQTag), followed by reversed-phase UPLC on a C18 column ( $1.7 \mathrm{~mm} ; 2.1 \times 150 \mathrm{~mm})$ and UV detection at $260 \mathrm{~nm}$.

\section{Water quality parameters}

Water quality parameters (temperature, salinity, dissolved oxgen, and $\mathrm{pH}$ ) were monitored routinely, once a day, using an YSI 556 multi probe meter (Yellow Spring Instruments Co., Yellow Springs, OH, USA). Ammonia-nitrogen was monitored weekly, and samples for analyzes of ammonia were collected at the exit of the experimental tanks and analyzed using a DR/890 Portable Colorimeter (Hach Lange, Düsseldorf, Germany).

\section{Statistical analysis}

All statistical analyses were made by using the Statistical Analysis Software Program of SAS $^{\circledR} 2002-2005$. All growth data were subjected to analysis of variance (ANOVA). Differences among treatment means were determined by Tukey's multiple range test at a $P<0.05$ level of significance. A polynomial regression was calculated to fit the data. The adequate level of methionine for achieving efficient growth and conversion efficiency for adults Florida Pompano were estimated using broken-line regression analysis $(Y=a+b X$; ROBBINS et al., 1979). 


\subsection{Results}

Water quality

Water quality parameters were determined as described previously and are presented in Table 6. No water quality complications occurred during the growth trial and the parameters were maintained within acceptable ranges for Florida pompano.

Table 6 - Water quality parameters during the feeding trial.

\begin{tabular}{ccccc}
\hline Temperature $\left({ }^{\circ} \mathrm{C}\right)$ & $\begin{array}{c}\text { Dissolved oxygen } \\
(\mathrm{mg} / \mathrm{L})\end{array}$ & $\mathrm{pH}$ & $\begin{array}{c}\text { Salinity } \\
(\mathrm{ppt})\end{array}$ & $\begin{array}{c}\text { Total ammonia } \\
\text { nitrogen }(\mathrm{mg} / \mathrm{L})\end{array}$ \\
\hline $30.21(0.04)$ & $10.47(1.12)$ & $8.02(0.27)$ & $37.54(0.40)$ & $0.08(0.00)$ \\
\hline
\end{tabular}

Data are means \pm (standard deviation).

\section{Diets analysis}

Analysis of the amino acid and nutrient compositions of the six test diets indicate that there was good agreement between the intended nutrient levels (based on the feed ingredients compositions) and the amounts present in the final dry diets. A satisfying increase in methionine content was obtained in the diets, although it was not identical to the quantities added initially. These small discrepancies may be due to sampling errors or random variability in the samples sent for analysis. The final levels of methionine were $0.52,0.71,0.92,1.11,1.29$, and $1.56 \%$ of the diet (dry matter basis), respectively, by adding crystalline L-methionine (Table 5).

\section{Animal performance}

Fish performance (initial and final individually weight, weight gain, FE, FCR, PER, SGR and survival) results for the 45 days feeding trial are presented in Table 7. Animals showed complete acclimation to the facility's water and culture systems and accepted all experimental diets with no noticeable palatability problems. Some suggestive differences in performance of Florida pompano were observed among the treatments. Significant difference in weight gain (from 153.6 to $202.5 \%$ ), and specific growth rate (from 2.06 to $2.45 \%$ ) were observed in fish fed the basal diet (D-1) and diet D-6, respectively. Relative high coefficients of variation among the three tanks of the same treatment was found for both D-1 and D-6 (12\% and 16\%, respectively) 
(Figure 4). PER was significant lower for the basal diet (D-1), compared with the D-5 and D-6. Overall, the diet supplemented with the higher level of L-methionine showed the best performance results. No significant differences were observed within the FCRs among the treatments. All tanks displayed good survival over the 45 days feeding period, ranging from 95.0 to $100.0 \%$ (Table 7 ).

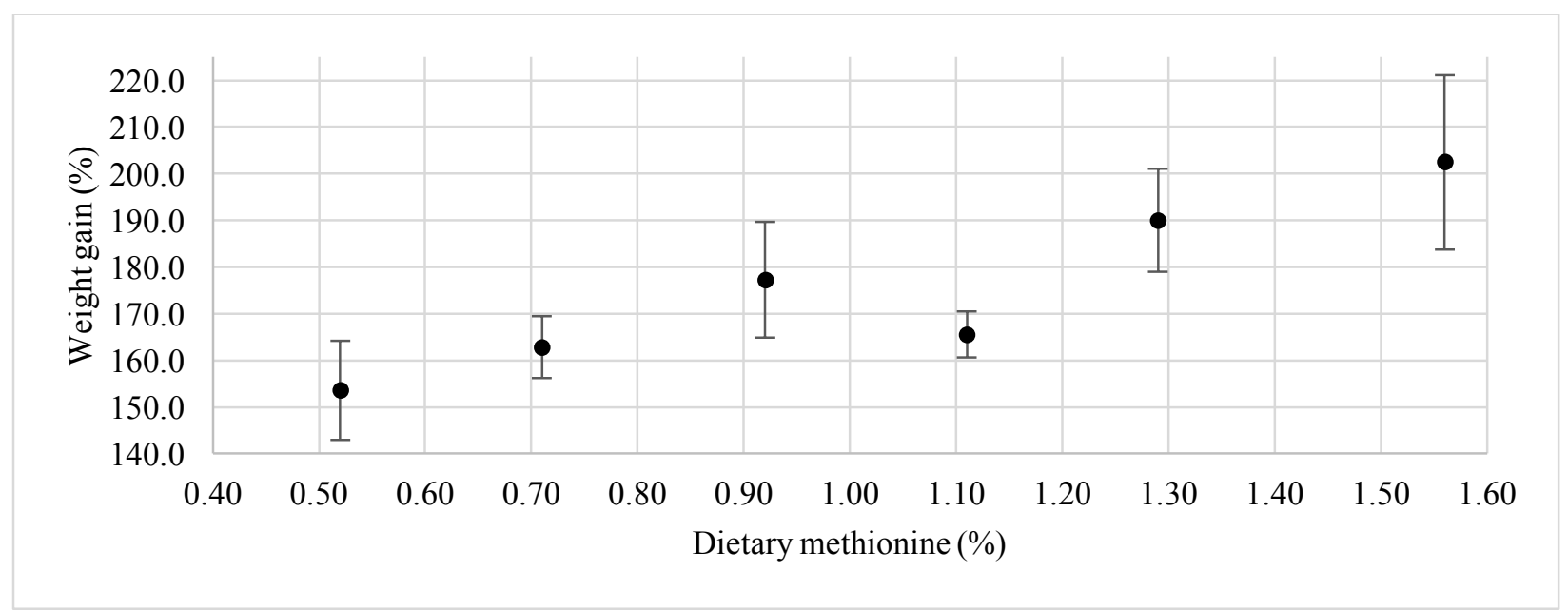

Figure 4 Relation between weight gain (\%) and dietary methionine (\%) among the six experimental diets with graded levels of L-methionine. Error bars represent \pm standard deviation. 


\section{Feed intake}

The total feed intake ( $\mathrm{kg}$, as fed basis) over the 45 days is presented in Figure 5. No significant differences were found among the treatments. The average daily feed intake was $5.38 \%$ of the body weight per fish.

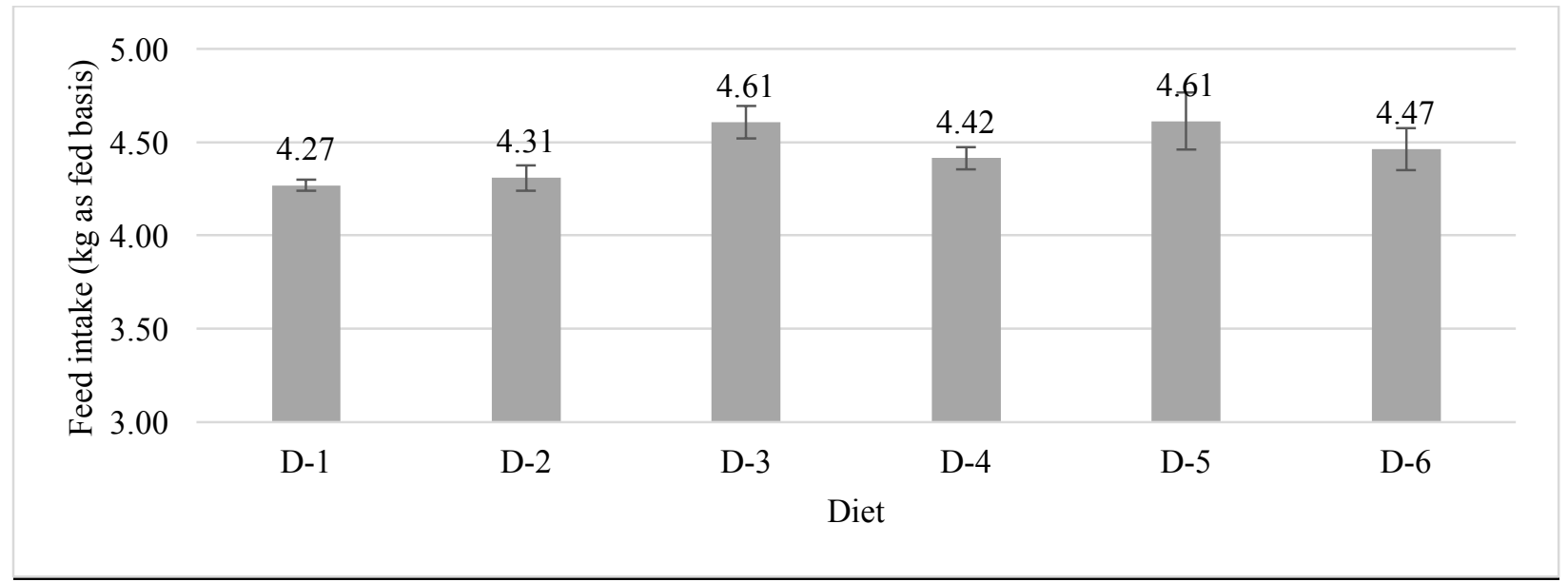

Figure 5 Total feed intake (kg, as is basis) of juvenile Florida pompano Trachinotus carolinus fed diets with graded levels of dietary methionine for 45 days (sum weigh; $n=3$ ). 
Table 7 - Initial weight, final weight, survival, weight gain, feed efficiency (FE), feed conversion rate (FCR), protein efficiency ratio (PER), and specific growth ratio (SGR) of Florida pompano Trachinotus carolinus fed diets with graded levels of dietary methionine for 45 days.

\begin{tabular}{lllllllll}
\hline Diet & $\begin{array}{l}\text { Initial weight } \\
(\mathrm{g})\end{array}$ & $\begin{array}{l}\text { Final weight } \\
(\mathrm{g})\end{array}$ & $\begin{array}{l}\text { Weight gain }^{2} \\
(\%)\end{array}$ & FE $^{3}$ & FCR $^{4}$ & PER $^{5}$ & SGR $^{6}$ & Survival $(\%)^{\mathrm{a}}$ \\
\hline $\mathrm{D}-1$ & $55.3(1.43)$ & $140.0(2.5)^{\mathrm{a}}$ & $153.6(10.6)^{\mathrm{a}}$ & $0.42(0.02)^{\mathrm{ab}}$ & $2.39(0.09)$ & $1.00(0.04)^{\mathrm{ab}}$ & $2.06(0.10)^{\mathrm{a}}$ & $100.0(0.0)$ \\
D-2 & $54.0(1.49)$ & $141.9(6.0)^{\mathrm{ab}}$ & $162.8(6.6)^{\mathrm{a}}$ & $0.39(0.04)^{\mathrm{a}}$ & $2.60(0.27)$ & $0.93(0.09)^{\mathrm{a}}$ & $2.15(0.06)^{\mathrm{ab}}$ & $95.0(5.0)$ \\
D-3 & $55.9(1.33)$ & $154.8(3.3)^{\mathrm{ab}}$ & $177.3(12.4)^{\mathrm{ab}}$ & $0.43(0.04)^{\mathrm{ab}}$ & $2.33(0.21)$ & $1.02(0.08)^{\mathrm{ab}}$ & $2.26(0.10)^{\mathrm{ab}}$ & $96.7(3.3)$ \\
D-4 & $56.4(0.92)$ & $149.9(5.0)^{\mathrm{ab}}$ & $165.6(5.0)^{\mathrm{ab}}$ & $0.44(0.01)^{\mathrm{ab}}$ & $2.25(0.05)$ & $1.07(0.02)^{\mathrm{ab}}$ & $2.17(0.04)^{\mathrm{ab}}$ & $100.0(0.0)$ \\
D-5 & $54.8(0.83)$ & $159.0(8.5)^{\mathrm{ab}}$ & $190.0(11.1)^{\mathrm{ab}}$ & $0.48(0.01)^{\mathrm{b}}$ & $2.09(0.03)$ & $1.15(0.02)^{\mathrm{b}}$ & $2.36(0.08)^{\mathrm{ab}}$ & $100.0(0.0)$ \\
D-6 & $53.4(0.63)$ & $161.5(8.6)^{\mathrm{b}}$ & $202.5(18.7)^{\mathrm{b}}$ & $0.47(0.02)^{\mathrm{ab}}$ & $2.14(0.11)$ & $1.17(0.06)^{\mathrm{b}}$ & $2.45(0.14)^{\mathrm{b}}$ & $95.0(5.0)$ \\
\hline
\end{tabular}

Data are means \pm (standard error mean) for 3 replicates per treatment.

Values with the same superscript in a column are not statistically different as determined by Tukey's multiple range test $(P<0.05)$.

${ }^{1}$ Percent of methionine of the analyzed experimental diets.

${ }^{2}$ Weight gain $=($ final weight - initial weight $) /$ initial weight $* 100$.

${ }^{3} \mathrm{FE}-$ feed efficiency $=$ final weight - initial weight $) /$ total dry feed intake.

${ }^{4} \mathrm{FCR}-$ feed conversion ratio $=$ grams fed $/$ grams weight gained.

${ }^{5} \mathrm{PER}$ - protein efficiency ratio = grams weight gained / grams protein fed.

${ }^{6} \mathrm{SGR}-$ specific growth rate $=(\ln$ final weight - initial weight $) /$ days $\left.* 100\right)$. 
Visceral somatic and hepatosomatic index

Visceral somatic index (VSI) was constant as inclusion rate of L-methionine source increased, with no significantly difference between the treatments (Table 8). The range of VSI was 4.72-5.47 with the lowest VSI from the D-4 and the highest VSI in fish fed the diet containing $0.52 \%$ of methionine (D-1). Hepatosomatic index (HSI) ranged from 1.81 to 2.18 and was no significantly impacted by dietary treatment. Smallest livers were observed in fish fed the diet containing more than $0.71 \%$ of methionine (Table 8 ).

Table 8 - Visceral somatic (VSI) index and hepatosomatic index (HSI) of Florida pompano, Trachinotus carolinus fed diets with different dietary methionine levels for 45 days.

\begin{tabular}{lll}
\hline Diet & $\mathrm{VSI}^{1}$ & $\mathrm{HSI}^{2}$ \\
\hline D-1 & $5.47(0.50)$ & $2.18(0.24)$ \\
D-2 & $5.14(0.45)$ & $2.10(0.37)$ \\
D-3 & $4.81(0.29)$ & $1.87(0.25)$ \\
D-4 & $4.72(0.20)$ & $1.81(0.18)$ \\
D-5 & $5.03(0.66)$ & $1.93(0.57)$ \\
D-6 & $5.13(0.52)$ & $1.97(0.23)$ \\
\hline
\end{tabular}

Data are means \pm (standard error mean) for 3 replicates per diet.

${ }^{1}$ Visceral somatic index $(\mathrm{VSI})=($ viscera weight $/$ fish weight $) * 100$.

${ }^{2}$ Hepatosomatic index $(\mathrm{HSI})=($ liver weight $/$ fish weight $) * 100$.

\section{Broken-line regression}

On subjecting the percentage of weight gain data to a straight-line single breakpoint model, a breakpoint was found at $1.08 \%$ of methionine (Figure 6). The resulted $\mathrm{R}^{2}$ was equal to 0.30 . The optimal dietary methionine levels for maximal growth of juvenile pompano were estimated to be $1.08 \%$, corresponding to $2.51 \%$ of dietary protein (dry matter basis). 


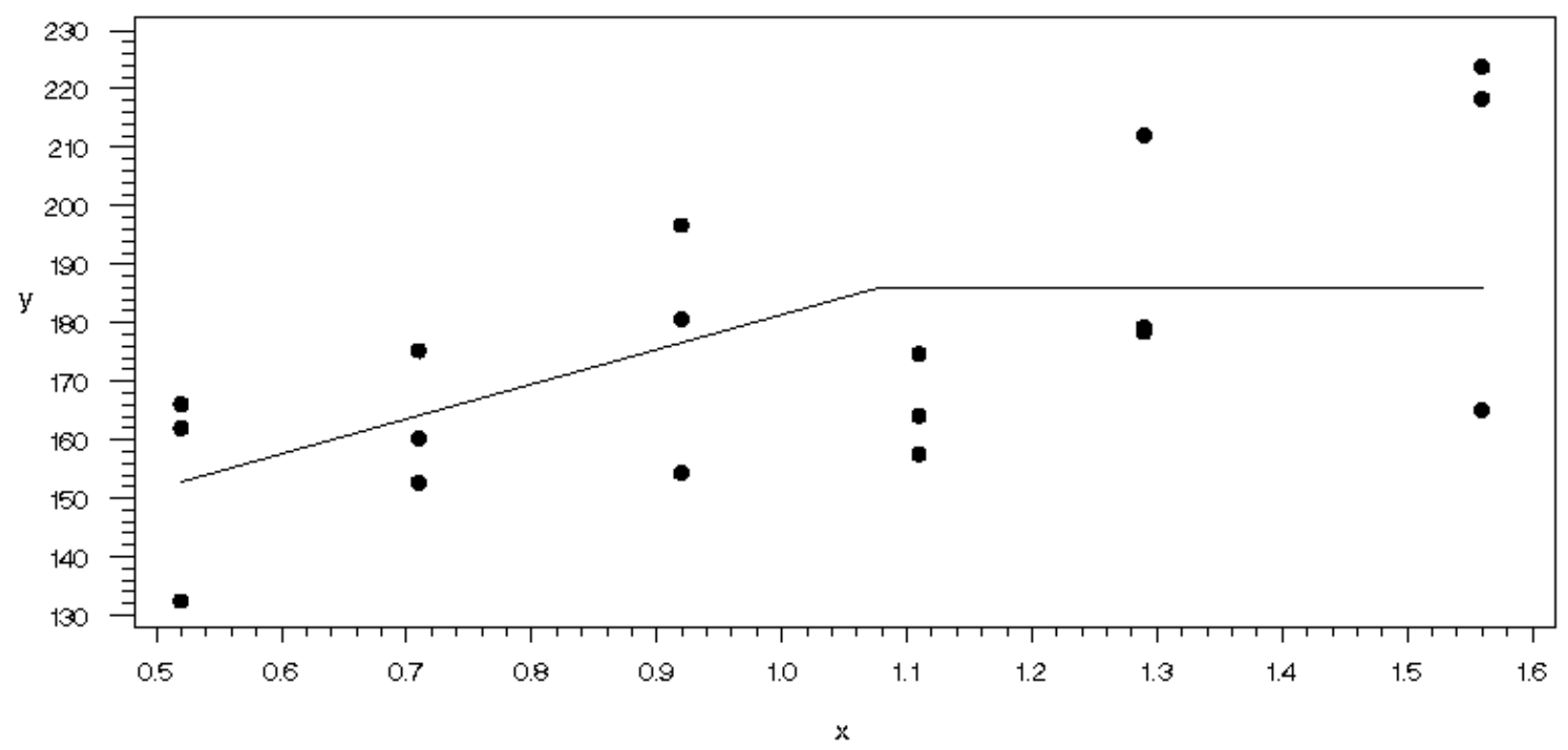

Figure 6 Relation between dietary methionine level $(x)$ and weight gain (y) of juvenile Florida pompano, as described by a straight-line broken-line regression model. 


\subsection{Discussion}

Based on weight gain, the dietary methionine requirement suggested from the broken-line regression analysis was $1.08 \mathrm{~g} / \mathrm{kg}$ of methionine, $\mathrm{R}^{2}=0.30$, however the low $\mathrm{R}$-square and high variation among the three replicates per diet does not provide sufficiency robustness for its estimation. Surprisingly, the differences in weight gain were not more obvious given the rather broad range of dietary methionine levels that were fed. Nevertheless, it was observed a trend of increasing weight gain as the methionine levels increased. This result may suggest that cysteine levels in the diets were contributing to the total sulfur amino acid requirement and preventing overt signs of deficiency. However, all diets had relatively low levels of cysteine (0.27\%). An important aspect of refining a species requirement for total sulfur amino acid (TSAA) is determining the cysteine sparing value for methionine. Since the high variability in the growth results between the replicates, this approach was not assessed. Methionine can be converted to cysteine via homocysteine and serine. Presence of cysteine in a diet can limit the amount of methionine that must be converted to cysteine, thereby reducing the overall amount of methionine required to meet the requirement for TSAA (LEWIS, 2003). The ability of cysteine to spare a portion of the dietary methionine requirement has been demonstrated in various terrestrial animals and several fish species (NRC, 2011).

Certain dietary EAA deficiencies have been attributed to inferior growth and feed efficiency in most studies (WILSON, 2002). In the present study, fish fed diets containing methionine at sub-optimal levels (D-1 and D-2) tended to have lower growth. Increasing methionine concentration in the diets up to $0.92 \%$ (D3) improved the growth performance and feed utilization. However, further increase in the dietary methionine levels (D-4, D-5 and D-6) did not show significant differences in growth and feed utilization in this study. The stable growth performance of fish fed diets containing higher levels of methionine (D-4, D-5 and D-6) may be due to the fact that the higher levels of dietary methionine may not be sufficient to induce toxic effects on the growth of this fish. The stabilized growth performance at higher levels of methionine was also recorded in earlier studies (TWIBELL et al., 2000; NGUYEN; DAVIS, 2009). Excess dietary methionine may be toxic to some fish and accordingly result in reduced growth (CHOO et al., 1991). Growth depression was absent in this study perhaps because the levels used were not high enough to induce toxicity. Dietary methionine deficiency resulted in 
the formation of cataracts in some fish species (RUCHIMAT et al., 1997; TAKAGI et al., 2001), but was not observed in the present study. The SGR in this study ranged from $2.06-$ to $2.45 \%$. Other investigators using smaller sized Florida pompano report SGR values ranging from 3.50 to 3.90\% (LAZO et al., 1998; ROSSI; DAVIS, 2012; WEIRICH et al., 2006).

The utilization of crystalline amino acids in practical diets of fish depends on the species ability to absorb and use such amino acids for protein synthesis as well as for other physiological functions. High dietary amino acid utilization requires that all amino acids are simultaneously present at adequate concentrations at the sites of protein synthesis. Hence, deficiency of an EAA limits protein synthesis to the level of that particular EAA, and the remainder being catabolized (SVEIER, et al., 2001). Of the various amino acids required for protein synthesis, methionine is clearly the most toxic (BENEVENGA, 1974). Therefore, graded levels of methionine in diets should result in responses for multiple criteria ranging from deficiency through adequacy to excess (BAKER, 1987). Various statistical approaches have been applied to estimate the methionine requirement of fish (TWIBELL, et al., 2000; NGUYEN; DAVIS, 2009; ABIDI; KHAN, 2011).

The choice of a statistical model is critical to interpret the nutrient requirement. Generally, non-linear models are reckoned as most suitable for evaluating results from doseresponse experiments (COWEY, 1995; SCHUTTE; PACK, 1995; RODEHUTSCORD, et al., 1997). Biologically, systems rarely work in perfectly linear fashions, so the non-linear models are more intuitive for careful observers of scientific data than models with linear functions (LERMAN; BIE, 1975). The many statistical models used by different researchers to interpret the dose response relationship has also contributed to the variability in estimates of requirements. Discrepancies in estimates of requirements with different mathematical models are not uncommon and the broken-line model generally predicts lower estimates of requirements than do non-linear models. BAKER (1986) attributes this phenomenon to the particular definition of requirement held within each model. While curvilinear models select requirement values which support maximum responses in all animals in a population, the broken-line model selects the requirement for the average animal in a population, which is necessarily less. In the present study, further statistical approaches were not done because of the high variation among the three replicates from each treatment. 
Another possible explanation for the poor feed utilization, is that the feed was not efficiently digested. WILLIAMS et al. (1985) determined the transit time of feed through the gut of Florida pompano to be about $3 \mathrm{~h}$. They suggest that the short transit time might explain the relatively low digestion rates obtained for some nutrients (i.e., lipids). It is possible that feeding to satiation twice per day might lead to reduce digestion and assimilation rates by Florida pompano. Fish were observed to eat voraciously until fully satiated. This large intake of food over a relatively short period of time may result in increased movement of food through the digestive system and a subsequent reduction in digestion. It has been demonstrated in the sockeye salmon that growth can be improved if the are fed continuously for 15 hour /day as compared to satiation three times per day (SHELBOURNE et al., 1973). In addition, the high amount of cellufill might have increase the gut transit time due to the high fiber content, which is not normal for Florida pompano. Poor FCRs were also observed within all diets. Consequently, further research is warranted to evaluate digestion rates and feeding strategies for this species.

The combination of purified and practical ingredients in nutrient requirement studies are an attempt by researchers to achieve higher rates of growth than are commonly observed with diets containing large amounts of synthetic amino acids or other purified ingredients (COWEY; LUQUET, 1983). Underestimation of the sulfur amino acid contents of diets due to improper analytical procedures and the use of different forms of methionine to supplement the basal diet can create further differences in experimental results. The factorial design of experiments has also been identified as an important source of variability in the estimation of methionine and phenylalanine requirements because these amino acids can be partially replaced by cysteine and tyrosine respectively (RUMSEY et al., 1983). For diet composition, it is important to prepare palatable and nutritious semi-purified diets to ensure that the fish will reach its maximum growth potential while precisely determining the minimum EAA requirement.

The wide variations reported in the amino acids requirement studies among species may be due to fish size, age, laboratory condition including feeding regime, feed allowance, water temperature, stock density and ingredients used for experimental diets, such as casein, gelatin, fish-meal, soybean meal and crystalline amino acids in various combinations (KIM et al., 1992; RODEHUTSCORD et al., 1997; LUO et al., 2005; FORSTER; DOMINY, 2006; MAI et al., 2006). It has also been reported that different levels of cysteine and sulfur amino acid-related 
nutrient such as choline in test diets could also be ascribed to some variability in TSAA requirement (KASPER et al., 2000; TWIBELL et al., 2000). When two or more nutrients in a fish diet are interrelated, it is necessary to consider how their presence and quantity will influence the growth of fish and economic benefits of fish production. Methionine is the source of the methyl donor S-adenosyl methionine, the metabolite that provides methyl groups in a variety of reactions including the de novo synthesis of choline from phosphatidylethanolamine (EL-GENDY et al., 2012). It has been reported that one-third of the total methionine supplement can be used to synthesize choline (EMMANUEL; KENNELLY, 1984; LOBLEY et al., 1996). Because of these metabolic relationships, dietary supply of choline affects methionine requirements and methionine supply can affect choline metabolism (EL-GENDY et al. 2012). Since information on choline requirement of Florida pompano is completely lacking, level of dietary choline in this study was supplemented at $0.23 \%$, which may be adequate to prevent the interaction between dietary methionine and choline.

Recent studies have indicated taurine requirements for a number of species, such as Japanese flounder Paralichthys olivaceus (KIM et al., 2003; KIM et al., 2005), sea bream Pagrus major (MATSUNARI et al., 2008), yellowtail Seriola quinqueradiata (MATSUNARI, et al., 2005; TAKAGI et al., 2006), and cobia Rachycentron canadum (LUNGER et al., 2007). ROSSI; DAVIS, 2012 and ROSSI; DAVIS, 2014 working with Florida pompano fed diets supplemented with taurine (plant based proteins in combination with about $14 \%$ meat and bone meal with blood or $14 \%$ poultry by-product meal), obtained enhanced animal growth and survival. A complete dose-response study later revealed that taurine requirement in Florida pompano was $0.54-0.65 \%$ (SALZE et al., 2014), which is in accordance with the current trial that diets were supplemented with taurine at $0.46 \%$, resulting in a final dietary content of $0.70-0.72 \%$ ( $\%$ diet). 


\subsection{Conclusions}

In conclusion, the range of methionine levels employed in this study may not have been broad enough to accurately measure the dietary concentration necessary to estimate the total sulfur amino acid requirement of Florida pompano. In addition, high variation results among the three replicates per diet did not provide sufficiency robustness for its estimation. Lastly, methionine is essential for the growth of Florida pompano and this fish is able to efficiently utilize crystalline form of methionine.

However, further longer-term studies are required to quantify the total sulfur amino acid requirement of adults Florida Pompano, Trachinotus carolinus and determine the replacement value of cysteine for methionine, in order to optimize the soy-based product in aquaculture feeds. The present study within 45 days should not have been enough to show significant differences among the treatments and longer duration would be recommended in future trials. 


\subsection{References}

ABIDI, S. F.; KHAN, M. A. Total sulphur amino acid requirement and cystine replacement value for fingerling rohu Labeo rohita: effects on growth, nutrient retention and body composition. Aquaculture Nutrition, v. 17, p. e583-e594. 2011.

BAKER, D. H. Construction of assay diets for sulfur-containing amino acids. Methods in Enzymology 143, 297. 1987.

BENEVENGA, N. J. Toxicities of methionine and other amino acids. Journal of agricultural and food chemistry, v. 22(1), p. 2-9. 1974.

CAI, Y.; BURTLE G. J. Methionine requirement of channel catfish fed soybean meal-corn-based diets. Journal of Animal Science, v. 74, p. 514-521. 1996.

CHOO, P.; SMITH, T. K.; CHO, C. Y.; FERGUSON, H. W. Dietary excesses of leucine influence on growth and body composition of rainbow trout. Journal of Nutrition, v. 121, p. 1932-1939. 1991.

COWEY, C. B. Protein and amino acid requirements: a critique of methods. Journal of Applied Ichthyology, v. 11, n. 3-4, p. 199-204. 1995.

COWEY, C. B.; LUQUET, P. Physiological basis of protein requirements of fishes. Critical analysis of allowances. Colloques de l'INRA (France). 1983.

DAVIS, D. A.; RHODES, M.; QUINTERO, H. E. Update on nutrition research with Florida pompano (Trachinotus carolinus). Abstracts of the 25th Annual Meeting of the Alabama Fisheries Association. 2009

EL-GENDY, M. E.; EL-RIEDY, K. F.; SAKR, H. S.; GAAFAR, H. M. Effect of rumen protected methionine and/or choline additives on productive performance of zaraibi goats. Nature and Science, v. 10, p. 35-41. 2012.

EMMANUEL, B.; KENNELLY, J. J. Kinetics of methionine and choline and their incorporation into plasma lipids and milk components in lactating goats. Journal of Dairy Science, v. 67, p. 1912-1918. 1984

FORSTER, I. P.; DOMINY, W. G. Efficacy of three methionine sources in diets for Pacific white shrimp, Litopenaeus vannamei. Journal of the World Aquaculture Society, v. 37(4), p. 474-480. 2006.

FURUYA, W. M.; BOTARO, D.; NEVES, P. R.; SILVA, L. C. R.; HAYASHI, C. Lysine requirement of Nile tilapia (Oreochromis niloticus), for grow-out phase. Ciências Rural, v. 34, p. 1571-1577. 2004.

GATLIN, D. M. et al. Expanding the utilization of sustainable plant products in aquafeeds: a 
review. Aquaculture Research, v. 38, n. 6, p. 551-579. 2007.

GOFF, J. B.; GATLIN, D. M. Evaluation of different sulphur amino acid compounds in the diet of red drum, Sciaenops ocellatus, and sparing value of cystine for methionine. Aquaculture, v. 241, p. 465-477. 2004.

KASPER, C. S.; WHITE, M. R.; BROWN, P. B. Choline is required by tilapia when methionine is not in excess. Journal of Nutrition, v. 130, p. 238-242. 2000.

KEEMBIYEHETTY, C. N.; GATLIN, D. M. Total sulfur amino acid requirement of juvenile hybrid striped bass (Morone chrysops x M. saxatilis). Aquaculture, v. 110, p. 331-339. 1993.

KIM, K. I.; KAYES, T. B.; AMUNDSON, C. H. Requirements for sulfur amino acids and utilization of D-methionine by rainbow trout (Oncorhynchus mykiss). Aquaculture, v. 101(1), p. 95-103. 1992.

KIM, S. K.; TAKEUCHI, T.; AKIMOTO, A.; FURUITA, H.; YAMAMOTO, T.; YOKOYAMA, M.; MURATA, Y. Effect of taurine supplemented practical diet on growth performance and taurine contents in whole body and tissues of juvenile Japanese flounder Paralichthys olivaceus. Fisheries Science, v. 71. 2005.

KIM, S. K.; TAKEUCHI, T.; YOKOYAMA, M.; MURATA, Y.; KANENIWA, M.; SAKAKURA, Y. Effect of dietary taurine levels on growth and feeding behavior of juvenile Japanese flounder Paralichthys olivaceus. Aquaculture, v. 250, p. 765-774. 2005.

LAZO, J. P.; DAVIS, D. A.; ARNOLD, C. R. The effects of dietary protein level on growth, feed efficiency and survival of juvenile Florida pompano (Trachinotus carolinus). Aquaculture 169, 225-232. 1998.

LERMAN, P. M.; BIE, S. W. Problems in determining the best levels of essential nutrients in feeding stuffs. The Journal of Agricultural Science, v. 84, n. 03, p. 459-468. 1975.

LEWIS, A. J. Methionine-cystine relationships in pig nutrition. In: Amino Acids in Animal Nutrition (ed. by J.P.F. D’Mello), pp. 143-156. CABI Publishing, Cambridge, MA. 2003.

LOBLEY, G. E.; CONNELL, A.; REVEL, D. The importance of transmethylation reactions to methionine metabolism in sheep: effects of supplementation with creatine and choline. British Journal of Nutrition, v. 75, p. 47-56. 1996.

LUNGER, A. N.; MCLEAN, E.; CRAIG, S. R. The effects of organic protein supplementation upon growth, feed conversion and texture quality parameters of juvenile cobia (Rachycentron canadum). Aquaculture, v. 264, n. 1, p. 342-352. 2007. 
LUO, Z.; LIU, Y. J.; MAI, K. S.; TIAN, L. X.; YANG, H. J.; TAN, X. Y.; LIU, D. H. Dietary Lmethionine requirement of juvenile grouper Epinephelus coioides at a constant dietary cystine level. Aquaculture, v. 249(1), p. 409-418. 2005.

MAI K. S.; WAN, J. L.; AI, Q. H.; XU, W.; LIUFU, Z. G.; ZHANG, L.; ZHANG, C. X.; LI, H. T. Dietary methionine requirement of large yellow croaker, Pseudosciaena crocea R. Aquaculture, v. 253, p. 564-572. 2006.

MATSUNARI, H.; TAKEUCHI, T.; TAKAHASHI, M.; MUSHIAKE, K. Effect of dietary taurine supplementation on growth performance of yellowtail juveniles Seriola quinqueradiata. Fisheries Science, v. 71, p. 1131-1135. 2005.

MOON, H. Y.; GATLIN, D. M. Total sulfur amino acid requirement of juvenile red drum, Sciaenops ocellatus. Aquaculture, v. 95(1-2), p. 97-106. 1991.

NGUYEN, T.N.; DAVIS, D. A. Re-evaluation of total sulphur amino acid requirement and determination of replacement value of cystine for methionine in semi-purified diets of juvenile Nile tilapia, Oreochromis niloticus. Aquaculture Nutrition, v. 15, p. 247-253. 2009.

NIU, J. et al. Quantitative dietary methionine requirement of juvenile golden pompano Trachinotus ovatus at a constant dietary cystine level. Aquaculture Nutrition, v. 19, n. 5, p. 677-686. 2013.

NRC (National Research Council). Nutrient Requirements of Fish and shrimp. National Academy of Sciences, Washington, DC. 2011.

POHLENZ, C.; BUENTELlO, A.; MWANGI, W.; GATLIN, D. M. Arginine and glutamine supplementation to culture media improves the performance of various channel catfish immune cells. Fish Shellfish Immunology, v. 2012; p. 32:762-8. 2009.

RICHE, M. Evaluation of digestible energy and protein for growth and nitrogen retention in juvenile Florida pompano, Trachinotus carolinus. Journal of the World Aquaculture Society. v. 40, p. 45-57. 2009.

RICHE, M.; WILLIAMS, T. N. Apparent digestible protein, energy and amino acid availability of three plant proteins in Florida pompano, Trachinotus carolinus L. in seawater and lowsalinity water. Aquaculture Nutrition, v. 16, p. 223-230. 2010.

RICHE, M.; WILLIAMS, T. N. Fish meal replacement with solvent extracted soybean meal or soy protein isolate in a practical diet formulation for Florida pompano (Trachinotus carolinus, L.) reared in low salinity. Aquaculture Nutrition, v. 17. 2011.

ROBBINS, K. R.; NORTON, H. W.; BAKER, D. H. Estimation of nutrient requirements from growth data. Journal of Nutrition, v. 109, p. 1710-1714. 1979. 
RODEHUTSCORD, M.; BECKER, A.; PACK, M.; PFEFFER, E. Response of rainbow trout (Oncorhynchus mykiss) to supplements of individual essential amino acids in a semipurified diet, including an estimate of the maintenance requirement for essential amino acids. The Journal of nutrition, v. 127(6), p. 1166-1175. 1997.

ROSSI, W., DAVIS, D. A. Meat and Bone Meal as an Alternative for Fish Meal in Soybean Meal-Based Diets for Florida Pompano, Trachinotus carolinus L. Journal of the World Aquaculture Society, v. 45(6), p. 613-624. 2014.

ROSSI, W.; DAVIS, D. A. Replacement of fishmeal with poultry by-product meal in the diet of Florida pompano Trachinotus carolinus L. Aquaculture, v. 338, p. 160-166. 2012.

RUCHIMAT, T., MASUMOTO, T., HOSOKAWA, H.; SHIMENO, S. Quantitative methionine requirement of yellow-tail (Seriola quinquiradiata). Aquaculture, v. 150, p. 113-122. 1997.

RUMSEY, G. L.; PAGE, J. W.; SCOTT, M. L. Methionine and cystine requirements of rainbow trout. The Progressive Fish-Culturist, v. 45(3), p. 139-143. 1983.

SCHUTTE, J. B.; PACK, M. Sulfur amino acid requirement of broiler chicks from fourteen to thirty-eight days of age. 1. Performance and carcass yield. Poultry Science, 74(3), 480487. 1995.

SEDGWICK, R. W. Effect of ration size and feeding frequency on the growth and food conversion of juvenile Penaeus merguiensis de Man. Aquaculture, v. 16(4), p. 279-298. 1979.

SVEIER, H.; NORDAE, H. S.; BERGE, G. E.; LIED, E. Dietary inclusion of crystalline D- and L-methionine: effects on growth, feed and protein utilization, and digestibility in small and large Atlantic salmon (Salmon salar L.). Aquaculture Nutrition, v. 7, p. 169-181. 2001.

TAKAGI, S., MURATA, H., GOTO, T., ENDO, M., YAMASHITA, H., UKAWA, M. Taurine is an essential nutrient for yellowtail Seriola quinqueradiata fed non-fish meal diets based on soy protein concentrate. Aquaculture, v. 280(1), p. 198-205. 2008.

TAKAGI, S.; SHIMENO, S.; HOSOKAWA, H.; UKAWA, M. Effect of lysine and methionine supplementation to a soy protein concentrate diet for red sea bream Pagrus major. Fisheries Science, v. 67(6), p. 1088-1096. 2001.

TWIBELL, R. G.; WILSON, K. A.; BROWN, P. B. Dietary sulphur amino acid requirement of juvenile yellow perch fed the maximum cystine replacement value for methionine. Journal of Nutrition, v. 130, p. 612-616. 2000.

VIOLA, S.; MOKADY, S.; RAPPAPORT, U.; ARIELLI, Y. Partial and complete replacement of fishmeal by soybean meal in feeds for intensive culture of carp. Aquaculture 26, 223- 
236. 1982.

WALTON, M. J.; COWEY, C. B.; ADRON, J. W. Methionine metabolism in rainbow trout fed diets of differing methionine and cystine content. Journal of Nutrition, v. 112, p. 15251535. 1982.

WEIRICH, C. R. An overview of U.S. pompano research and culture efforts to date. Aquaculture America 2011 - Meeting Abstract 344. 2011.

WEIRICH, C.; RICHE, M. Acute tolerance of juvenile Florida pompano, Trachinotus carolinus L., to ammonia and nitrite at various salinities. Aquaculture Research, v. 37, p. 855-861. 2006.

WILliAMS, S.; LOVELL, R. T.; HAWKE, J. P. Value of menhaden oil in diets of Florida pompano. The Progressive Fish-Culturist, v. 47(3), p. 159-165. 1985.

WILSON R. P. Amino acids and protein. In: Fish Nutrition (3rd ed.) (ed. by J.E. Halver \& R.W. Hardy), pp. 143-179. Academic Press, San Diego, CA. 2002. 


\section{GENERAL CONSIDERATIONS}

The primary goal of this thesis was to evaluate the feeding and nutrition of tropical farmed fish and shrimp, targeting its applicability to aquaculture farming. Chapter 1 presented the panorama of aquafeed quality for tilapia and shrimp, assessing proximate nutrient composition, physical water stability, in vitro degree of protein hydrolysis (DH), and evaluation of near-infrared spectroscopy (NIRS) with preliminary tests on soybean meal samples. The results indicated that the development and use of compound aquafeeds has been a major factor in the global expansion of fish and shrimp farming, and efficient feed management is critical to maintain and improve the financial and environmental viability of the industry. The in vitro $\mathrm{pH}$-stat species-specific method to determine the degree of protein hydrolysis $(\mathrm{DH})$ showed to be a useful tool to evaluate the commercial feed quality. Assay conditions (temperature, medium salinity, incubation time, and enzyme: substrate ratios) according to the animal physiological status should be taken into account for the consistency of the in vitro determination. Routine use of the method may also be dependent on the ready availability of more ready-to-use sources of enzyme extracts. NIRS showed to be an efficient tool for rapidly assessing feed quality in terms of protein degree of hydrolysis, and it can be used to connect the advanced scientific knowledge generated by scientists in laboratories with the application in the field.

In Chapter 2, four diets (one reference, two experimental cold pelleted, and one commercial extruded) was tested to evaluate acid-insoluble ash (AIA) and chromic oxide $\left(\mathrm{Cr}_{2} \mathrm{O}_{3}\right)$ as inert markers and feed processing methods (industrial extruded vs. laboratory cold pelleted) to determine apparent digestibility coefficient (ADC) of dry matter and crude protein of juvenile shrimp Litopenaeus vannamei. AIA showed to be an effective endogenous marker for digestibility trials with shrimp, however, for commercial feeds attention should be paid to the levels of AIA in the feed. The findings of this trial also highlight the importance of identifying suitable alternatives to chromic oxide as an inert marker for digestibility trials in shrimp. Analytical protocols should be revised and possibly by increasing the amount of sample, marker concentration may be increased and coefficient of variation reduced. Moreover, the extruded feed showed better animal performance than the cold pelleted feed. Extruded pellets promoted higher feed intake, better FCR, weight gain, and protein utilization. However, ADC of both feeds were not significantly different from each other. For future studies, industrial processing (extruded vs. pelleted) with accurately 
equal feed mixture should be tested, in order to compare feed performance at industrial applied standards.

In Chapter 3, two feeding trials were conducted with juvenile cobia, Rachycentron canadum: (1) feeding trial conducted within floating net cages to test the nutritional efficacy of different dietary feeding regimes ranging from the use of trashfish, in-house formulated feeds, to dry commercial extruded marine fish feed; and (2) feeding trial conducted within indoor waterrecirculated tanks to test the nutritional efficiency of different potential dietary fishmeal replacers within dry in-house prepared diets. Generally, fish performance was superior in the net-cage feeding trial compared with the indoor water-recirculated tank trial. Overall, the fish growth and performance of the experimental diets were very similar, showing that the alternative ingredients could be included and replace part $(50 \%)$ of the fishmeal component. The results from both trials concluded that the cobia requires practices diets with high levels of crude protein and lipid, and the inclusion of alternative plant-based and terrestrial animal protein sources was possible. The quantitative essential amino acid (EAA) requirement values estimated by the protein accretion method was highly correlated to the average of each of the EAA requirement for the species of carnivorous fish reported in the literature, and could be recommended for formulation of commercial feed for cobia. Using amino acids profile to set basis for dietary amino acids profile and requirements is a viable technique and may bring additional benefits of formulating diets eliciting higher feeding efficiency and reduced nutrient loss and waste and metabolites excretion. Also, the outcome of both trials suggest the need for nutritional improvement of existing commercial diets currently employed for cobia farming in Brazil. Finally, to ensure the applicability and rapid transfer of future research data to commercial farms, wherever possible, nutrition experiments with cobia (based on the use of practical diets) should be conducted in-situ on comparable marine fish farms, and the data generated should also be evaluated from an economic viewpoint. In addition, long term feeding trials are required from fingerling to market size with full nutritional and economic evaluation of results and fish quality parameters.

In Chapter 4, a tentative to quantify the total sulfur amino acid requirement of juvenile Florida Pompano Trachinotus carolinus, was performed using combinations of various soybean protein products in order to develop cost-effective and environmentally-friendly diets. 
There was an apparent tendency in the results, but the range of methionine levels employed in this study may not have been broad enough to accurately measure the dietary concentration necessary to estimate the total sulfur amino acid requirement of Florida pompano Trachinotus carolinus. In addition, high variation results among the three replicates per diet did not provide sufficiency robustness for its estimation. However, further longer-term studies are required to quantify the total sulfur amino acid requirement of adults Florida Pompano Trachinotus carolinus and determine the replacement value of cysteine for methionine, in order to optimize the soy-based product in aquaculture feeds. The present study within 45 days should not have been enough to show significant differences among the treatments and longer duration would be recommended in future trials.

Intensive work at the laboratory, experimental station, and field trips was required for the achievement of the objectives. Nevertheless, some improvements or future studies still could be made, e.g., measure and test different particle sizes for the ingredients used in the diets; increase the number of ingredient samples to develop more robust NIRS calibration curves; test higher amounts of feed sample in the attempt to reduce variation between replicates in the acid-insoluble ash fraction analysis; and conduct long term feeding trials from fingerling/juvenile to market size with full nutritional and economic evaluation of results. 


\section{APPENDIX}

\section{Shrimp Annotated Bibliography}

A document containing a comprehensive list of publications dealing with nutrition and feeding of farmed penaeid shrimp, was prepared using Aquatic Science and Fisheries Abstracts database (ASFA). The work was conducted with the support of The Brazilian National Council for the Development of Science and Technology (CNPq), and prepared as part of the activities of the AquaMar Research Project "Feeding Tomorrow's Fish: Environmental and Sustainable Aquaculture Feeds and Feeding Regimes for Marine Farming”. The project is funded by the CNPq's under "Science without Borders - Special Visiting Researcher" program. It mainly focuses on practical and more urgent subjects in feeding and nutrition of farmed marine fish and shrimp, for the potential benefit of Brazilian farmers. The literature review was part of the research program that was carried out by the AquaMar research team. The program also included technical visits to local farmers, feed manufacturers, laboratory, and field experiments with target species. There were compiled and screened over than 27.000 scientific articles from 1971 to 2014, and organized into 30 different subjects (index below). The document is available at http://www.aquahana.com/wp-content/uploads/2015/07/AQUAMAR-SHRIMP-FINAL.pdf. 


\title{
SHRIMP NUTRITION \& FEEDING
}

\section{A SELECTED ANNOTATED BIBLIOGRAPHY}

$$
1971-2014
$$

compiled by

\section{Albert G. J. Tacon, Thiago Raggi \& Daniel Lemos}

\author{
Laboratório de Aquicultura \\ Instituto Oceanográfico \\ Universidade de São Paulo \\ São Paulo, Brasil
}

for

The CNPq Research Project

\section{Feeding Tomorrow's Fish:}

Environmental and Economically Sustainable

Aquafeeds and Feeding Regimes for

Marine Aquaculture

AquaMar

São Paulo, June 2014

\section{Q Q CNPq

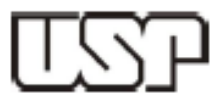




\section{SUBJECT INDEX}

1. Attractants \& feeding stimulants

2. Binders \& feed stability

3. Biofloc \& zero-exchange culture systems

4. $\quad$ Broodstock feeds \& feeding

5. Carbohydrates \& dietary fiber

6. Carotenoids \& pigmentation

7. Contaminants \& dietary disease risks

8. Digestion \& digestibility

9. Disease resistance \& immune response

10. Energy, growth \& general physiology

11. Environmental impacts \& life cycle analysis

12. Experimental methodology \& feeding trials

13. Feed ingredients $\&$ formulated feeds

14. Feed manufacture, processing \& storage

15. Feeding behavior \& feeding regime

16. Growth promotants \& miscellaneous feed additives

17. Gut microflora \& microbiology

18. Larval \& nursery feeds

19. Lipids, fatty acids \& metabolites

20. Minerals \& trace elements

21. Moulting \& exoskeleton

22. Mycotoxins

23. Natural foods \& feeding habits

24. Organoleptic \& gastronomic characteristics

25. Prebiotics \& probiotics

26. Production systems \& bioremediation

27. Proteins, amino acids \& metabolites

28. Reviews on shrimp nutrition

29. Vitamins \& antioxidants

30. Water quality, fertilization \& soils 